Universidad Nacional Autónoma de México Facultad de Estudios Superiores Zaragoza

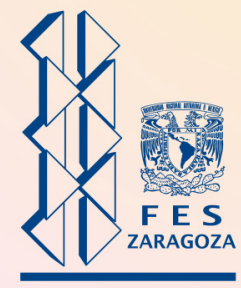

\title{
MEJORA TU CALIDAD DE VIDA Y RENDIMIENTO ACADÉMICO A TRAVÉS \\ DEL AUTOAPRENDIZAJE
}
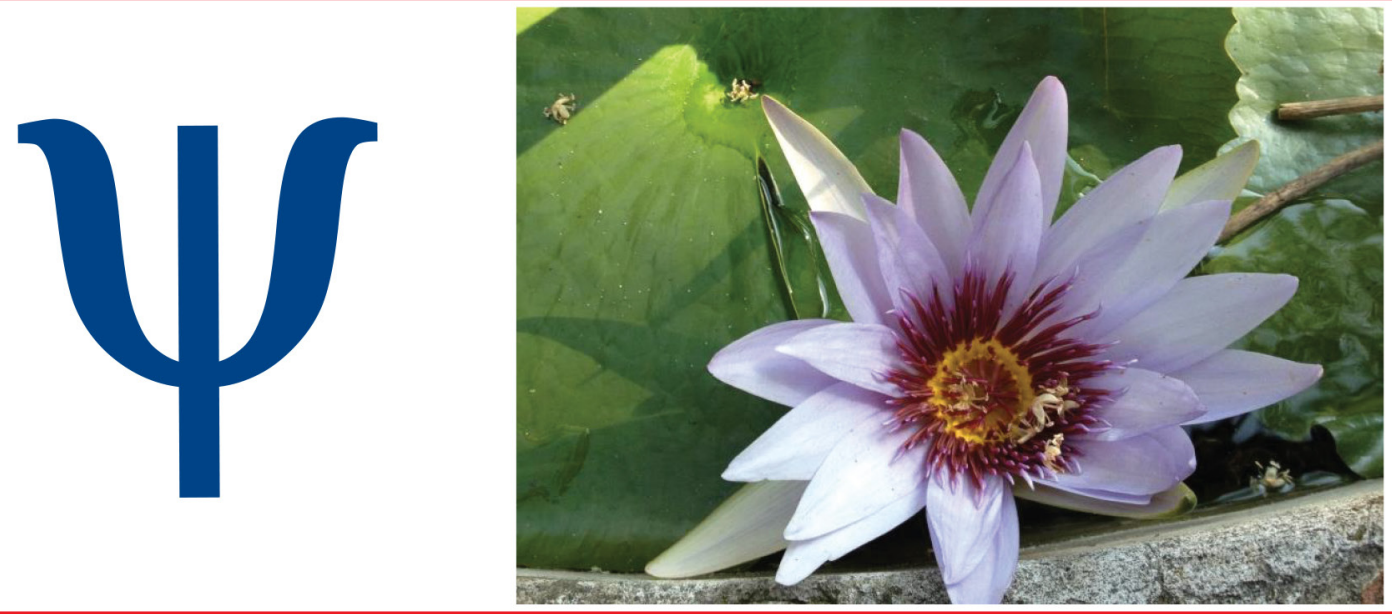

Coordinadores: Julieta María de Lourdes García Pérez J. Alejandra Villagómez Ruíz Gerardo Reyes Hernández 


\section{Mejora tu calidad de vida y rendimiento académico a través del autoaprendizaje}

Coordinadores:

Julieta María de Lourdes García Pérez

J. Alejandra Villagómez Ruíz Gerardo Reyes Hernández

Programa: PAPIME PE303213 
Universidad Nacional Autónoma de México

Facultad de Estudios Superiores Zaragoza

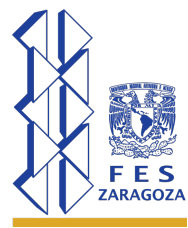

\section{Datos para catalogación bibliográfica}

Coordinadores: Julieta María de Lourdes García Pérez, J. Alejandra Villagómez Ruíz, Gerardo Reyes Hernández.

Mejora tu calidad de vida y rendimiento académico a través del autoaprendizaje

UNAM, FES Zaragoza, marzo de 2016.

Peso: 7,838 KB.

ISBN: 978-607-02-7683-5

Diseño de portada: Julieta María de Lourdes García Pérez.

Diseño y formación de interiores: Claudia Ahumada Ballesteros.

Proyecto PAPIME PE303213.

\section{DERECHOS RESERVADOS}

Queda prohibida la reproducción o transmisión total o parcial del texto o las ilustraciones de la presente obra bajo cualesquiera formas, electrónicas o mecánicas, incluyendo fotocopiado, almacenamiento en algún sistema de recuperación de información, dispositivo de memoria digital o grabado sin el consentimiento previo y por escrito del editor.

Mejora tu calidad de vida y rendimiento académico a través del autoaprendizaje

D.R. @ Universidad Nacional Autónoma de México

Av. Universidad \# 3000, Col. Universidad Nacional Autónoma de México, C.U.,

Delegación Coyoacán, C.P. 04510, México, D.F.

Facultad de Estudios Superiores Zaragoza

Av. Guelatao \# 66, Col. Ejército de Oriente, Delegación Iztapalapa, C.P. 09230, México, D.F. 


\section{Contenido}

Página

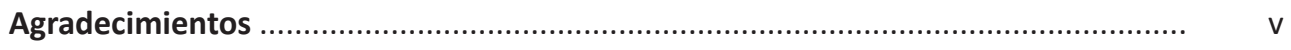

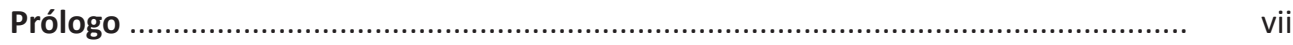

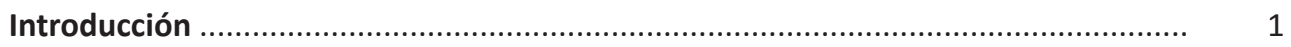

1. Soy resiliente: fortalezco mis habilidades para superar la adversidad .................. 5 Julieta María de Lourdes García Pérez

2. Desarrollo de la comunicación eficiente …….......................................................

J. Alejandra Villagómez Ruíz

3. Tan importante como respirar: la comunicación. Aprende a expresar lo que 71 piensas y sientes

Verónica Lizeth Vences Cruz

4. Elementos para establecer relaciones interpersonales positivas …….................. 105 Sandra Galindo Méndez

5. Diálogos con amor: comunicación en pareja ....................................................... 165

Tania Ivett Hernández Granados

6. Tus ideas ¿a tu favor o en tu contra? ................................................................ 203

Adrián Barragán Rangel

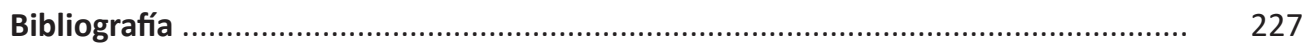

Índice de autores ..................................................................................... 233

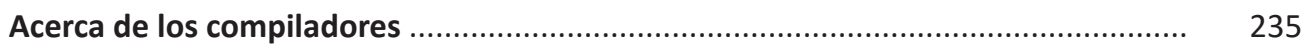





\title{
Agradecimientos
}

\begin{abstract}
Aradecemos infinitamente a Dios, a la Vida, la UNAM, la FES Zaragoza, La Carrera de Psicología, la Unidad de Formación Integral, al Programa de Apoyo a Proyectos para la Innovación y Mejoramiento de la Enseñanza PAPIME PE303213 "Mejora del Rendimiento Académico a través del Fortalecimiento de las Habilidades Psicosociales", por su valioso apoyo y financiamiento, que hizo posible la realización de este libro. Al departamento de Publicaciones, al Programa Servicio Social Fortalecimiento de Habilidades Psicosociales para Estudiantes Universitarios y especialmente enfocado a los Psicólogos por su compromiso y dedicación, a los pasantes quienes contribuyen de manera muy importante a contribuir con el trabajo de la creación e impartición de talleres, así como de las Guías para el estudiante, motivo del presente texto. A la comisión editorial por su valiosas observaciones, a los estudiantes, al LDG Gabriel Villagómez por la portada. Al apoyo de los Profesores y Amigos con sus recomendaciones. A todas aquellas personas quienes de una o de otra manera han hecho posible que este libro salga a la luz. Y la comunidad estudiantil quienes con participar en los talleres que impartimos nos retroalimentan y estimulan a seguir adelante, mejorando para servirles mejor cada día.
\end{abstract}





\section{Prólogo}

El mundo cambia con extraordinaria rapidez, así mismo, cada vez es más interdependiente — por los efectos de la globalización, que inciden sobre todas las estructuras sociales y cuyos impactos nos afectan de manera particular en las diferentes esferas de la vida, de manera que no tienen las mismas repercusiones en todas las personas. Aspecto que dificulta las relaciones interpersonales.

Para los tiempos actuales requieres del desarrollo de nuevas habilidades y actitudes que te permitan aprender a lo largo de la vida de una manera eficaz y autónoma y así mismo, que te ayuden a regular tus habilidades, pensamientos y emociones, a fin de que puedas tener una vida más feliz. De tal manera que, OPS/OMS (2001) plantean que, debes trabajar y desarrollar 10 habilidades para la vida, a saber: Conocimiento de ti mismo, empatía, respeto a ti mismo y a los demás, comunicación efectiva, saber relacionarse con las demás personas, tomar decisiones, resolver problemas y conflictos, pensar crítica y creativamente, tener un adecuado manejo de tus emociones, así como un manejo del estrés. Estas habilidades psicosociales son aquellas aptitudes necesarias y suficientes para tener un comportamiento adecuado y positivo que te permita enfrentar eficazmente las exigencias y retos de la vida diaria. Lo que se basa en dos características o medidas de su programa, 1ㅇ) en la importancia de la competencia psicosocial de la promoción de salud: que supone bienestar físico, mental y social de las personas y 2a) en los cambios sociales y familiares de las últimas décadas, que implican que parece difícil que estos programas vengan del interior de los hogares. De tal manera que se propuso que estos vinieran desde las instituciones educativas, en contexto de la educación formal.

El presente libro es resultado del trabajo realizado por los profesores que brindamos la capacitación de conocimientos y habilidades a los pasantes de la Carrera de Psicología quienes han colaborado en el programa de investigación denominado: "MEJORA DEL ReNDIMIENTo académico a Través del fortalecimiento de habilidades Psicosociales", que tiene como 
objetivo fortalecer y desarrollar las Habilidades Psicosociales que te permitan tener una actividad plena en su proceso de aprendizaje y en la totalidad de tu vida familiar, social y laboral.

Pensamos en los beneficios que este servicio brinda de manera vasta, a los estudiantes y personas que asisten a tomar los talleres vivenciales, es insuficiente, dado que tienen que estar en tiempo-momento en un lugar determinado, por ello es que, deseamos ampliarlos y llevarlos a un sector más extendido de la comunidad. Por lo cual, planeamos y elaboramos este texto con un conjunto de Guías para el Estudiante (o persona interesada), como una estrategia adecuada, ya que te permite que con tus propios recursos cognitivos, fisiológicos y conductuales fomentar tus habilidades psicosociales.

Las guías tienen como características: objetivos claros, actividades individuales y grupales en las cuales puedes invitar a participar familiares o amigos, fomentando una mejor comunicación, una invitación a la reflexión de cada actividad y una evaluación de cada una de ellas, que te permitirán hacer una retroalimentación para que sepas qué aspectos estás haciendo bien y en cuáles debes reforzar y practicar un poco más, de tal forma que llegues a un aprendizaje significativo y al fortalecimiento de tus habilidades psicosociales. Las Habilidades que podrás desarrollar en esta guía son: Resiliencia, Comunicación Eficiente, Expresa lo que Piensas y Sientes, Relaciones Interpersonales Positivas, Diálogos con Amor y ¿̇us ideas en tu favor o en tu contra?

Esperamos realmente que este trabajo que realizamos con tanto entusiasmo pueda serte de gran ayuda, en función de que podrás realizarlo a tu propio ritmo y de acuerdo con tus necesidades. Nos encantaría tener comentarios de tu experiencia con este libro pequeño gran libro.

Si tienes alguna duda o comentario, te puedes comunicar al siguiente correo: serviciosocialhabilidadesps@gmail.com o contactarnos a la página: http://www.facebook. com/pages/Servicio-Social-Habilidades-Psicosociales-FES-Zaragoza-UNAM/365377223558755 


\section{Introducción}

Las habilidades para la vida son las aptitudes que te permiten tener un comportamiento adecuado y positivo para que enfrentes eficazmente los retos y desafíos del día a día, a fin de que tengas un desempeño adecuado en la vida. A menudo se presentan situaciones en las que los estudiantes se deben enfrentar a amenazas y utilizar estrategias que les permitan afrontar y tener mejores condiciones personales, familiares, sociales, escolares y laborales. Para actuar deben tomar en cuenta sus motivaciones individuales, dentro de las normas sociales y culturales.

La institución educativa es un espacio estratégico de formación y desarrollo, pues es ahí en donde los estudiantes elaboran conocimientos, fortalecen hábitos e interiorizan valores, por lo que es ideal para la enseñanza de habilidades para la vida. Los estudiantes tienen habilidades sociales y se manifiestan cuando saben expresar su sentir y hacerse escuchar, de esta manera, consiguen aquello que se proponen, hacen respetar sus derechos, a la vez que respetan los de los demás. Las habilidades para la vida o psicosociales tienen una relación estrecha con la salud y la resiliencia, lo cual te permite el desarrollo personal, teniendo conductas resilientes así como estilo de vida saludable ya que, son un aspecto clave del desarrollo humano.

Estas habilidades se agrupan en tres dimensiones: a) habilidades interpersonales y para la comunicación; b) habilidades para la toma de decisiones y el pensamiento crítico; y, c) habilidades para afrontar situaciones y el manejo de ti mismo (OMS, 2003). Entre las dos primeras se incluye la comunicación verbal y no verbal, la negociación/rechazo, la asertividad, la habilidad para establecer relaciones interpersonales sanas, la cooperación y la empatía; desde las habilidades para la toma de decisiones y el pensamiento crítico se identifican la toma de decisiones/solución de problemas, la autoevaluación y clarificación de valores. Por último, entre las habilidades para afrontar situaciones y el manejo de ti mismo se encuentran el autoconocimiento-autoconcepto, manejo de sentimientos, el 
Mejora tu calidad de vida y rendimiento académico a través del autoaprendizaje

locus de control interno y el control del estrés (Mangrulkar, Whitman \& Posner, 2001), todos estos aspectos que trabajarás en cada guía.

De tal manera que, las habilidades para la vida se desarrollan o se fortalecen al tener un ambiente que favorezca una educación más humana, ya que el ambiente contribuye a tu formación integral como persona; al desarrollo de tus capacidades relacionadas con los valores de la convivencia; a conocer y manejar tus emociones y conflictos; a entender a los demás; a fijarte propósitos significativos en tu vida; a aprender a comprometerte, a ser solidario. Las habilidades te permitan afrontar con éxito las exigencias y desafíos de la vida cotidiana en tu familia, en tu escuela y tu comunidad.

Ya que las habilidades para la vida te permiten insertarte activamente tanto en tu propio proceso de desarrollo como en el de la construcción de normas sociales (Bravo \& Garzón, 2010). Así mismo, te posibilitan saber cómo pensar, te proveen de herramientas para la solución de problemas, la toma de decisiones, el control de emociones, el aprendizaje de habilidades, pueden convertirse en un medio para fortalecerte y empoderarte (Niremberg, 2006).

Las habilidades las puedes utilizar en diversas situaciones, ya que una misma habilidad tiene aplicaciones en distintos ámbitos. Así como se necesitan varias habilidades para una determinada situación, siendo algunas más relevantes que otras. Un ejemplo sería cuando se te presenta algún problema es importante manejar las emociones, tener buena comunicación así como el pensamiento crítico.

Para el desarrollo de estas habilidades puedes hacer uso del autoaprendizaje, ya que tú eres capaz de aprender por ti mismo y es un objetivo implícito de tu proceso de crecimiento ser independiente y para ello, deberás tener alta autorregulación, que es el producto de estas habilidades psicosociales, combinadas con tu responsabilidad y compromiso. Por medio de lo cual, adquieres conocimiento de habilidades, valores y actitudes por tu cuenta. 
El presente texto se compone por un conjunto de Guías y tiene como objetivo ayudarte que seas un estudiante enfocado a tu autoaprendizaje, que busques por ti mismo la información y que lleves adelante las prácticas o experimentos, en ocasiones le puedes pedir a la gente que te ayude, y en otras puedes experimentar viendo y anotando lo que ocurre en la sociedad frente a tus ojos, así puedes ir viendo cómo funcionan las habilidades interpersonales y tomar las medidas necesarias para que te ayuden a vivir plenamente gozando de la vida y ayudándote a tener una alto rendimiento académico y profesional.

Cada guía ha sido creada por diferente autor, por ello tiene un estilo propio de escritura. Lo cual puede ser importante, en virtud de que cada estilo puede ir complementando los elementos que manejo otro autor. Así mismo, en cada una encontrarás alguna señal para las actividades a realizar. Espero que vayas notando que hay habilidades que cada uno de las guías manejará, pero cada uno con su nota particular, lo que le pone un sabor diferente al proceso. Bienvenido y a disfrutar de este proceso de crecimiento personal y aunque no lo creas grupal. Porque los cambios que experimentes los vas a compartir con tu familia y compañeros.

J. Alejandra Villagómez Ruiz Enero 2016 



\title{
Soy resiliente: fortalezco mis habilidades para superar la adversidad
}

\author{
Julieta María de Lourdes García Pérez
}

a época actual del siglo XXI ha traído grandes cambios en cuanto a la estructura familiar y -social, ejerciendo muchas presiones sobre los jóvenes, tales como el nacer en la pobreza, vivir en un ambiente psicológicamente insano con desintegración familiar, drogadicción y vandalismo, las cuales son condiciones de alto riesgo para su salud física y mental; así mismo las presiones familiares y personales para tener una ejecución de primera, generan altos niveles de estrés, en virtud de que de esa manera podrás acceder a mejores condiciones de escuelas, de trabajo y mejor calidad de vida. La resiliencia se ocupa de observar aquellas condiciones que posibilitan el abrirse al desarrollo más sano y positivo (Kotliarenco, Cáceres \& Fontecilla, 1997), es decir, a salir adelante a pesar de la adversidad.

De tal manera que, la presente guía tiene el objetivo de ayudarte a ser consciente de quién eres y a fortalecer las habilidades que contribuyan a que salgas bien librado, fortalecido y feliz ante la adversidad. Aspecto que marca la diferencia entre ser gente de bien y un miserable.

Para trabajar te recomiendo que lo hagas en un lugar tranquilo y seguro. Y que siempre tengas a mano un cuaderno y lápiz o bolígrafo. Cuando encuentras puntos suspensivos “..." después de un texto significa que te tomes tu tiempo para realizar lo que ahí se plantea y cuando encuentres +++ antes de un texto es que se trata de un ejercicio para que lo realices, así que prepara tu cuaderno y bolígrafo, así como a tu cerebro.

ACTIVIDAD 1. MANEJO DE UN DIARIO. Que tiene el objetivo ayudar a tener un seguimiento del proceso de cambio y a la reflexión al final de esta guía y cuando continúes en el diario vivir. 
Mejora tu calidad de vida y rendimiento académico a través del autoaprendizaje

+++ Consigue un cuaderno de buen tamaño o en el mismo que ya tienes, para que sea tu compañero en este proceso. Vas a anotar todo lo que observes de manera significativa, anotarás de manera más clara posible: qué situación se presentó, cómo te sentiste, qué pensaste y qué hiciste, cuando detectes que cambiaste subráyalo. Es importante que seas cuidadoso para evitar que alguien lo vea, no porque sea malo, sino porque es muy personal.

Reflexión: Al final de cada día vas a hacer un comentario de lo más significativo sobre qué observaste. $\mathrm{Y}$, en el mismo momento en que trabajas con la guía puedes hacer los comentarios que desees, estos te ayudan a entender lo que ocurre. Y conforme avances puedes ver hacia atrás y reflexionar qué has cambiado. Y lo puedes continuar usando con las otras guías y en tu vida diaria.

ACTIVIDAD 2. Fortalecer tu Autoconciencia, que se refiere a distinguir los procesos internos del hombre de los que es posible adquirir conocimiento.

+++ Para ello, te invito a realizar la Autobservación Activa. Te recomiendo que grabes las siguientes instrucciones, dejando tiempo suficiente para que realices cada acción: Para iniciar el ejercicio, realiza una inhalación profunda, suave y lenta, llevando el aire hasta el vientre y al exhalar relájate..., y entra en contacto con todos tus canales sensoriales, tratando de captar toda la información posible..., ahora levántate, percibiendo todas las sensaciones que emanan de esta actividad..., muévete siendo consciente de todo lo que implica..., sacúdete observándote minuciosamente..., camina variando el ritmo y nota todas las sensaciones..., brinca tomando en cuenta todo lo que ocurre en ti..., ríe $y$ experimenta en plenitud la vivencia.., ve de todos los modos posibles con todo tu ser... y observa todo lo que puedas... pero ahora sé consciente de que ahora estás viendo con más detalle..., oyes sonidos más suaves y con mejor modulación..., sientes mejor..., ves con mayor intensidad y colorido... anota lo que observaste.

Reflexiona. ¿Qué aprendiste?, ¿Qué cambios notaste? ¿Qué te gustó más? ¿Qué se te hizo más difícil? Y ahora ¿Cómo lo puedes aplicar a tus estudios y a tus actividades personales? 
1 Soy resiliente: fortalezco mis habilidades para superar la adversidad

Y procura continuar con este estilo de observación consciente a lo largo de tu día y al menos durante el tiempo que te lleve trabajar con esta guía.

Así puedes ver que la Autoconciencia es el proceso mediante el cual adquieres conocimiento acerca de ti mismo, en un momento particular del tiempo, a partir de lo cual, defines una serie de circunstancias internas y externas que están determinando la forma de pensar, sentir, comportarse y relacionarse. Así como, las actitudes que posees con relación a lo que te interesa y motiva hacia la satisfacción de tus necesidades personales.

Es oportuno que sepas que, la conciencia es vigilancia o estado de alerta y coincide con tu participación en los acontecimientos del ambiente que te rodea. Es una función compleja, ya que: "Si dices, que estás enojado/a, quizá lo estés, pero puede que también estés equivocado/a; puede que en realidad tengas miedo, estés celoso/a, o que sientes las dos cosas".

¿Cómo puedes hacer para tener una conciencia exacta de lo que te está pasando físicamente y qué estás sintiendo psicológicamente? A esta pregunta responde el principio de la autoconciencia, en virtud de que ésta sólo se dará cuando la información afectiva entra en el sistema perceptivo, en el que debes identificar las emociones que estás experimentando y cuáles son aquellas que te están faltando en tu vida actual.

Las emociones son un conjunto complejo de respuestas químicas y neuronales que forman un patrón distintivo. Producidas por tu cerebro cuando detecta un estímulo emocionalmente competente, frecuentemente es una respuesta individual interna que te informa de las probabilidades de supervivencia.

Los sentimientos, en cambio, son la evaluación consciente que haces de la percepción de tu estado corporal durante una respuesta emocional, por ello, son con los que está más en contacto; en tanto que el afecto es un proceso de interacción social que estableces con dos o más organismos, generalmente seres vivos, que pueden ser personas o animales. 
Mejora tu calidad de vida y rendimiento académico a través del autoaprendizaje

A fin de que puedas seguir trabajando con tu autoconciencia, te presento unas actividades para que te familiarices más con los sentimientos.

+++ Los sentimientos pueden tener diferente intensidad, en la que puedes encontrar prácticamente tres niveles: baja, media y alta, que en su expresión cotidiana está en equilibrio (figura 1), considerada como adecuada.

\section{FIGURA 1 INTENSIDAD EMOCIONAL}

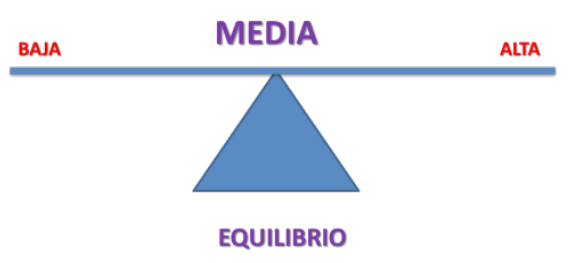

Los sentimientos en función a tus vivencias, pueden cambiar y en ese cambio tienden a bajar o subir. Y una vez pasado el impacto tienden al equilibrio. Pero hay ocasiones en las que, dicho equilibrio no se da, lo que te habla de un asunto a trabajar, es decir un área de oportunidad para encontrar la manera de hacerlo o pedir ayuda.

En el caso de tu expresión sea baja (figura 2), puedes notar un déficit en ese sentimiento. Y por ello, si de manera natural no sube o nunca ha estado arriba hay que trabajar con ella, para eso estás aquí.

FIGURA 2 INTENSIDAD EMOCIONAL

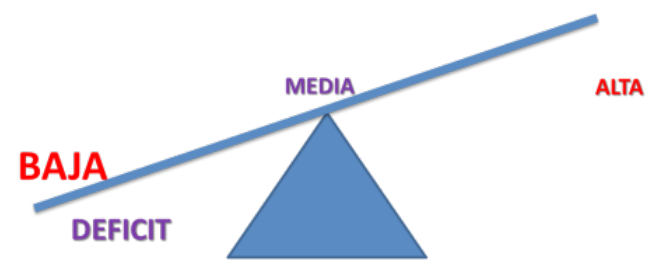


1 Soy resiliente: fortalezco mis habilidades para superar la adversidad

Si por el contrario, tu expresión es alta (figura 3) y así se mantiene o hace tiempo que está ahí, te está señalando la importancia de que te observes y entiendas porqué es así. Y veas qué te hace falta para reducirla y llevarla al equilibrio. Ya que de mantenerse puede desequilibrar tu salud como el caso del estrés, te llevaría al agotamiento.

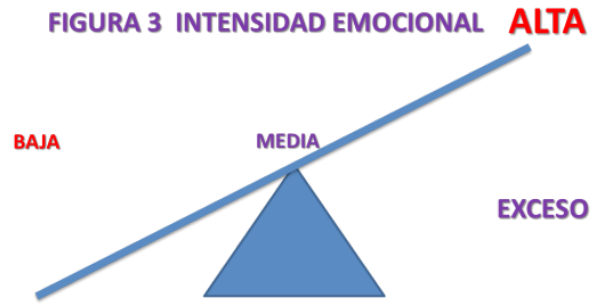

+++ Ahora realiza una lista con las emociones que has identificado hasta este momento e identifica el nivel en el que en este momento la experimentas.

Para que lo puedas hacer mejor, el primer paso será Aprender el nombre de los sentimientos más importantes: para ello, vas a conocer los sentimientos que de acuerdo a Tomkins (1963), en la siguiente actividad.

ACTIVIDAD 3. ExPLORANDo los SEntimientos, con el objetivo de que los experimentes, reconozcas, etiquetes adecuadamente y diferencies, enriqueciendo tu experiencia.

+++ En cada uno de los sentimientos que analizarás, anota en tu cuaderno 5 experiencias asociadas a ellos, de preferencia en que tú los hayas presentado y analices de la manera más profunda que te sea posible, a fin de que reconozcas cómo te sentiste y cómo actuaste en ese momento y finalmente que ocurrió después. Si tú no la has experimentado, piensa a quién has visto experimentarla y cómo fue el proceso para ella.

Atracción: sientes curiosidad, fascinación o intriga, le prestas atención e incluso te concentras en ello. Como un buen libro, un videojuego, aprender algo o alguien quien te interesa y te cuesta trabajo quitar los ojos o el pensamiento de ahí. 
Mejora tu calidad de vida y rendimiento académico a través del autoaprendizaje

Excitación: cuando sientes ilusión, felicidad o animación por algo, tal vez sólo piensas en eso. Como salir de vacaciones, conocer a alguien que te gusta, pensar en tu fiesta.

Repulsión: sientes que algo es muy desagradable y que lo deseas evitar. A una persona hostil, un platillo de apariencia desagradable, un animal fiero.

Satisfacción: te sientes complacido o contento por algo. Como jugar, acariciar, hacer un buen trabajo interesante, alcanzar una buena nota.

Alegría: es como si tu cuerpo estuviera lleno de felicidad, regocijo. Como festejar una fecha importante, sacaste la calificación máxima, das de brincos o bailas, haces cosas que estabas planeando, hacer un viaje, cuando lo tienes, listo sientes como un cosquilleo.

Euforia: es cuando experimentas la máxima excitación por algo que es inusitado, por algo que creías que no podría ser, sientes que viajas en un cohete. Tocar el cielo, sentir que explotas de felicidad.

Sorpresa: se da cuando adviertes algo que no esperabas, sentirte maravillado, pasmado o impresionado, al inicio no sabes que hacer. Encontrarte dinero en el piso, recibir un regalo, un cumplido.

Sobresalto: es la primera respuesta que experimentas cuando ocurre algo inesperado cerca de ti, que te asusta, te sacude, alarma o impacta. Te cae un animal de un árbol, sentarte en una silla mojada, que te salga alguien de pronto, que un perro ladre a tu lado.

Tranquilidad: es un estado de bienestar, calma, serenidad, sosiego y paz, que experimentas cuando las cosas están en armonía. Como después de una buena comida, te quedas en la sobremesa con una charla agradable, al final del día cuando todo está en su lugar, te recuestas y sientes paz.

Aflicción: te sientes preocupado, acongojado y a veces lloras o sollozas. Tienes que pagar una deuda y no tienes el dinero, una persona cercana está enferma y no le dan que tiene. 
1 Soy resiliente: fortalezco mis habilidades para superar la adversidad

Consuelo: cuando la situación está controlada, sientes alivio u optimismo. Ya sabes que tiene la persona y le dan el tratamiento adecuado y se va recuperando.

Angustia: estás atormentado, torturado o tienes un gran dolor o sufres una pena grande. Reconoces que algo que hiciste lastimó a alguien, sabes que acabas de perder a tu mejor amigo, el divorcio, una enfermedad, los despidos de otros compañeros en la empresa.

Temor: sientes miedo, susto, nerviosismo por qué piensas que algo malo está por suceder, o que alguien te dirá algo para amenazarte. El primer día de clases en una nueva escuela, o en un nuevo trabajo, ir por una calle oscura.

Confianza: te sientes valiente, audaz, esperanzado o intrépido, para realizar la tarea que se te solicita. Como desarrollar un tema que dominas, hacer actividades creativas.

Terror: significa que estás en el grado máximo de miedo, petrificado, aterrado o apanicado, tal vez te sientas paralizado y ni siquiera puedes pedir ayuda. Como una pesadilla, estar a punto de chocar, estar en un huracán o temblor fuerte.

Relajación: te sientes animado o calmado, porque estás en un lugar seguro. Como tu hogar, o estás con alguien fuerte, que te genera bienestar.

Enojo: sientes molestia o irritación. Esto te puede ocurrir de manera abrupta y rápido se te pasa, o bien va creciendo poco a poco, se prolonga e intensifica. Se experimenta de manera focalizada a alguien o algo en particular o bien de manera generalizada, contra todos o todo. Como si alguien te hubiera tomado algo muy personal y querido, un amigo rompe su promesa, o te castigan por hacer algo.

Odio: cuando el enojo se prolonga y se intensifica, se convierte a odio, rencor y resentimiento. Cada vez que ves al amigo que te traicionó, te acuerdas de cuando tus papás te castigaron injustamente. Está vinculado a la enemistad y la repulsión, lleva a tratar de evitar o destruir aquello que odian. Por lo cual, el sentimiento puede reflejarse a través de insultos o agresiones físicas. 
Mejora tu calidad de vida y rendimiento académico a través del autoaprendizaje

Paz: te embarga un estado de tranquilidad y amistad, en el que te sientes muy bien. Se puede presentar cuando observas la grandeza del mar, de la naturaleza, cuando te quedas absorto en esa contemplación, oír música sublime.

Cólera: indignación, furia, sentir hervir, grado superlativo de enojo, te lleva a estar fuera de control. Alguien te rompió algo muy preciado, explotas, gritas e insultas o en el colmo puedes aventar cosas e incluso pegarle. Cuando se te pasa luego te sientes mal, con culpa por lastimar a esa persona.

Calma: tranquilidad y paz, es esa sensación de que estás bien internamente experimentas un equilibrio con la vida. Como que trasciendes la condición mundana. Te siente feliz por estar vivo.

Vergüenza: sentirte desprotegido, desanimado, incomodo, cohibido, timido, apenado y culpable, por haberte comportado mal. Te sientes como si algo estuviera mal dentro de ti y de pronto todos lo supieran. Se puede presentar cuando pides ayuda y te responden "no me molestes", "ve a otro lado", "te dicen no llores como bebé", tienes que dar un tema y se te borra cuando enfrentas al grupo.

Orgullo: te sientes confiado, seguro, con gallardía. Te sientes muy bien y confiado con los resultados de tus trabajos y más si te dan un reconocimiento público, o cuando se lo dan a un ser querido.

Humillación: es sentirte profunda y públicamente avergonzado, mortificado, deshonrado, derrotado, enajenado, ante alguna ejecución pésima. Como estar en una fiesta y derramarte o a alguien le derrames algo, que se te rompa la ropa y se te vea una parte privada y todos te vean o te vea la persona que te interesa.

Regocijo: es un sentimiento de felicidad que te embarga al ser reconocido y por ello, sientes orgullo por los actos realizados, o el sentimiento de misión cumplida. 
1 Soy resiliente: fortalezco mis habilidades para superar la adversidad

Desprecio: cuando menosprecias a los demás y crees que tú vales más que ellos; es una defensa ante sentimientos dolorosos o incomodos. Dice el dicho: "la mejor defensa es el ataque". Algunos sinónimos son desdeño, pesado, sarcástico, presumido, altanero.

Humildad: se presenta cuando haces algo que otra persona interpreta como grandioso y dices no es para tanto, sólo hice lo que pude o lo que creí que debía hacer o bien, lo que era mi obligación.

Respeto: se presenta cuando tratas a los demás de buena manera y les das su lugar en la situación, sin importar lo ricos o pobres que sean, consideras que son seres humanos valiosos como tú mismo, ni más ni menos.

Asco: se manifiesta como una repulsión, aversión o repugnancia total por algo o alguien y normalmente no puedes estar en su presencia. Consideras que alguien se comporta de manera nauseabunda, pueda ser que ponga saliva en su pan, o que te traicione, o que te des cuenta de que no es tan bueno como pensabas, es falso.

Simpatía: es sentir afinidad, cariño o afecto por alguien que se comporta de buena manera y gana tu aprecio. Si en algún momento estás pasando por un problema y viene un amigo a ofrecerte ayuda, en ese momento experimentas una revaloración por él.

Vanidad: experimentas un sentimiento inadecuado de sentirse grandioso, merecedor de los más altos honores por tus acciones y lo que haces lo haces planeando y esperando ser reconocido. Te sientes superior, este sentimiento generalmente expresa un problema de deficiente valoración, así que inflas el ego para tratar de estar bien, pero si no recibes lo que esperas te enojas contra los demás y puedes ser grosero. Cuidado esto requiere atención urgente.

Reflexiona: Cómo pudiste sentir y experimentar cada sentimiento, notaste que hay mejores y más favorables, que son los que deseamos tener y con este conocimiento estás fortaleciendo tus tesoros y herramientas, ya que lo que conoces lo puedes trabajar. Estas 
Mejora tu calidad de vida y rendimiento académico a través del autoaprendizaje

guías pueden ayudarte, a manejar estas situaciones emocionales si trabajas bien con ellas, pero si ves que sigue el problema acércate a recibir orientación profesional.

Para poder controlar tu irritabilidad debes ser consciente de cuáles son los agentes desencadenantes y cuál es el proceso por el que surge tan poderosa emoción recuerda que debes: reconocer la emoción o el sentimiento y analizar en qué situación se dio, y cuáles fueron las consecuencias. Al ser más consciente la próxima vez en que percibas la situación, te puedes detener, respirar y decidir hacer algo diferente; sólo entonces podrás aprender a aplacarla y a utilizarla de forma apropiada. Para evitar el desaliento y motivarte, debes ser consciente de la razón por la que permites que ciertos hechos o afirmaciones negativas que afecten tu ánimo. A veces se relaciona con experiencias del pasado, cuando lo identificas lo puedes superar, reconociendo que no tiene sentido, que eso quedó en el ayer y ahora eso por ningún motivo te va a afectar, ya que tú lo has decidido y actuarás para quitarle poder.

Para ayudar a otros a ayudarse a sí mismos, debes ser consciente de tu implicación emocional en la relación. Sólo debes saber que es su decisión y tal vez ahora no estén dispuestos, tú cumples con proponerlo, pero no insistas ni permitas que te frenen, tú sigue adelante. Tú eres responsable de cambiar y ser mejor tú y los demás son responsables de sus cambios.

La clave de la autoconciencia está en SABER SiNTONIZAR con la abundante información -tus Sensaciones, Sentimientos, Valoraciones, Intenciones y Acciones- de que dispones sobre ti mismo. Esta información te ayuda a comprender cómo respondes, te comportas, comunicas y funcionas en diversas situaciones. AL PROCESAMIENTO DE TODA ESTA INFORMACIÓN ES A LO QUE SE LE DENOMINA AUTOCONSCIENCIA.

Un alto grado de autoconciencia puede ayudarte en todas las áreas de tú vida y especialmente en el estudio y el aprendizaje.

Esta autoconciencia te ayuda a reconocer que junto con los sentimientos o las emociones aparecen manifestaciones fisiológicas como transpirar, respirar con dificultad, el rubor 
1 Soy resiliente: fortalezco mis habilidades para superar la adversidad

o la palidez, la tensión muscular o la fatiga; manifestaciones cognitivas, como la falta de concentración, problemas de memoria y bloqueo de los procesos del pensamiento, tales como el olvido o la confusión; y, la conducta motriz o física desacelerada o acelerada, congelación o engarrotamiento y actuaciones adecuadas o erróneas.

Una herramienta clave de la autoconciencia es la TOMA DE CONCIENCIA del propio cuerpo y de sus señales de excitación.

Tienes que llegar a ser capaz de describir tu cuerpo y tu mente con vívido detalle, incluida la respiración, la transpiración, el desasosiego, la falta de concentración, los pensamientos inquietantes, el contenido de esos pensamientos, y en el caso de estados negativos como miedo o preocupación, los peligros específicos que promueven esos estados anímicos.

Empiezas a mirar las manifestaciones exteriores de tu excitación interior, como absolutamente naturales y comunes. Así mismo, comprendes que no matan y sabes positivamente que la conciencia les va quitando el poder a esas señales, sobre todo si las sientes y consideras como cotidianas, les estás quitando importancia.

Si tienes buena autoconciencia o conocimiento de ti mismo, conocerás tus propias debilidades y obtendrás la seguridad que brinda el tener una evaluación correcta de tus propias fuerzas. También puedes ser capaz de energizar a los demás, de comprometerte y confiar en quienes desarrollan una tarea contigo.

A fin de que ejercites con tú autoconciencia, es pertinente que Reconozcas tus EMOcionES Y SUS EFECTOS. Dado que esto te permitirá comprender los vínculos existentes entre tus pensamientos, palabras y acciones; reconocer el modo en que tus emociones influyen en tú rendimiento; saber qué emociones estás sintiendo y por qué, asimismo tendrás un conocimiento básico de tus valores y de tus objetivos.

Es importante que entiendas que las emociones son el resultado de una interacción entre tus: 
1. pensamientos o valoraciones cognitivas.

2. cambios fisiológicos o respuestas emocionales.

3. comportamientos o las acciones a las que tiendes.

4. contexto, que incluye tu educación, creencias y experiencias; es decir todo lo que te permite ser de la forma que eres y que imprime tu carácter y personalidad. Que son susceptibles de modificarse, de manera consciente e intencional.

Una adecuada valoración de ti mismo: incluye conocer estas interacciones, lo que te llevará a ser consciente de tus puntos fuertes y de los débiles; trabajando tus limitaciones, las conviertes en tus capacidades, fortalezas y recursos.

Practicarás, reflexionarás y serás capaz de aprender de la experiencia; serás sensible al aprendizaje sincero de la experiencia, a los nuevos puntos de vista y al desarrollo de ti mismo; además contarás con un sentido del humor que te ayudará a tomar responsabilidad de lo que haces y reconocer por qué lo ejecutas y que consecuencias obtienes al realizarlo. Una sensación muy clara de tú valor y de tus capacidades genera la confianza en ti mismo: cuando tengas esta competencia, manifestarás confianza en ti mismo y poseerás "presencia", podrás expresar tus puntos de vista impopulares y defender sin apoyo de nadie lo que consideras correcto, del mismo modo serás emprendedor y capaz de asumir decisiones importantes a pesar de la incertidumbre y las presiones. Tendrás carisma e inspirarás seguridad a quienes te rodean.

La conciencia en ti mismo y la autoconfianza se relacionan, y te ayudarán a creer en tu valía, lo que te permitirá desempeñarte mejor en tu vida diaria, porque esta creencia te motiva en parte, a trabajar más duro y durante mayor tiempo, y a perseverar a pesar de las adversidades, en virtud de que sabes que lo lograrás.

ACTIVIDAD 4. Gimnasia Cerebral. Con el propósito de activar y estimular las diferentes áreas corticales, para superar los problemas y los obstáculos psicológicos que te impiden ver las posibles soluciones a tus problemas. 
1 Soy resiliente: fortalezco mis habilidades para superar la adversidad

La Tarántula, al iniciar realiza una autobservación de tu estado emotivo y para ello, debes ponerte de pie, con los pies paralelos, abiertos al ancho de tus caderas, para que tengas un sostén firme. Imagina que tienes el cuerpo cubierto de arañas, que son los problemas que te agobian. Y para eliminarlas empiezas a sacudir con tus manos el cuerpo como arrancando esos animales que te molestan y al quitarlos siente el alivio que experimentas. Reflexiona: Con respecto a los cambios obtenidos en tu autopercepción y tu disponibilidad al cambio. Y la sensación de libertad que experimentas.

ACTIVIDAD 5. Autobservación: con la finalidad de que notes que la mayoría de las situaciones emocionales vienen de ti mismo.

+++ Realiza una autoobservación siguiendo los siguientes pasos:

1 observa tu mente o pensamiento, anota lo que más puedas de los pensamientos principales, los más frecuentes, los más fuertes anótalos, quizá te encuentres diciéndote algo así como: "yo que voy a observar", "esto es una tontería", "sólo estoy perdiendo mi tiempo", "si ni pienso nada" y así por el estilo, esos son pensamientos que se denominan derroteros o saboteadores son para hacerte desistir de las tareas que emprendes, así que sigues adelante y los anotas todos, realízalo durante el tiempo necesario, por $10 \mathrm{~min}$, es decir, hasta que sienta que los pensamientos automáticos dejaron de aparecer o están muy lentos.

2ㅇ Puedes grabar las siguiente actividad, para que lo puedas oír y trabajar, grábala como está, hablándote de usted es parte del ejercicio: "relájese un poco y cierre sus ojos...: suave y sensualmente frote sus manos y sea consciente de cómo está estimulando el sentido del tacto..., es como si estuviera poniendo muchos ojos en sus manos, dedos y piel..., ahora toque suave y lentamente la ropa que trae puesta, pieza por pieza... siempre con sus ojos cerrados toque lo que hay cerca de usted... ahora toque su cabello... su cara... descanse suavemente sus manos en su regazo, en sus piernas... ahora suavemente ponga su atención en su nariz, observe el entrar y salir del aire, note cómo está, frío... ligero... dulce..., empiece a notar las suaves notas que trae el aire, perciba el aroma de su ropa..., de su cabello..., de 
Mejora tu calidad de vida y rendimiento académico a través del autoaprendizaje

su perfume..., de su entorno..., inhale suavemente y exhale, moviendo suavemente pies y manos..., brazos y piernas..., su cuerpo, cuello y cabeza... y finalmente abra suavemente sus ojos, regresando al presente, y sin perder detalle, anote lo que observó".

3o Toca el turno a la observación de tus interacciones, observa cómo te sientes, actúas y que te dices cuando estas con personas en las siguientes situaciones: Queridas (amigos, hermanos, familiares), Obligadas (compañeros, maestros, vecinos), Desagradables (compañeros, gente egoísta), Hostiles (gente peleonera, gañanes), Autoritarias (directores, maestros, políticos), y, Mendigos (que te exigen que les des algo).

+++ Anota lo que observaste.

Reflexiona: Acerca de los diferentes procesos que has trabajado, pasa del pensamiento, a la interacción con diferentes situaciones, personas, y finalmente al mundo de las interacciones con diferentes relaciones. ¿De qué manera fue cada uno? ¿Cómo se caracterizan? ¿De qué manera se integran? ¿Qué aspectos personales te ayudó a trabajar este ejercicio? y ¿Qué te han aportado de manera integral?

ACTIVIDAD 6. Autoobservación Íntima, con el objetivo de que profundices el conocimiento interno.

+++ Graba este ejercicio, tal como viene, dando tiempo para actuar: "Ahora está listo para hacer una autoobservación más íntima..., va a sentarse cómoda y suavemente, va a cerrar sus ojos..., bien, ahora abrirá sus ojos de la mente... recuerde dejar sus ojos físicos cerrados... ok, ahora con los ojos de su mente vaya observando su cuerpo por dentro... note qué le llama la atención, y disfrute el viaje..., así mismo vaya notando tus emociones... recorra todo su cuerpo y cuando termine, sin abrir sus ojos siéntese bien derechito... suavemente respire profundo y al exhalar vaya moviendo suavemente todo su cuerpo, primero las manos y pies..., luego piernas y brazos..., tronco, cuello y cabeza... y al final suavemente abra sus ojos". Y escriba toda la información obtenida en el viaje. 
1 Soy resiliente: fortalezco mis habilidades para superar la adversidad

Reflexiona: Con respecto a ambos ejercicios: considerando las siguientes preguntas: ¿Qué cambios observaste en tu atención?, ¿Qué percibiste en tu interior, te costó trabajo hacerlo?, ¿Pudiste seguir todo el recorrido?, ¿Qué se te facilita y porque crees que es así? y ¿Este conocimiento de qué crees que te sirve?

Espero que con cada ejercicio vayas profundizando más y que tu conocimiento personal vaya fluyendo más, eso estaría muy bien, recuerda que este conocimiento te ayuda a aumentar tu autoconocimiento y a poder actuar de manera diferente a como hasta ahora lo habías hecho con plena ignorancia. Hoy puedes elegir y cambiar parte de tus pensamientos y mover sentimientos y de esta forma mejorar tus acciones y resultados, para ello necesitarás más práctica. ¡Sigue adelante!

ACTIVIDAD 7. CAPACIDADES Y LIMITACIONES con el objetivo de hacer conciencia de las propias capacidades y limitaciones y cuáles son factibles de desarrollo y cambio.

+++ En una hoja de tu cuaderno, la divides en dos columnas, y del lado derecho de la hoja enlista tus habilidades, talentos, capacidades, recursos y fuerzas positivas, y en el izquierdo las debilidades, limitaciones, incapacidades, errores, áreas de oportunidad. Trata de ser generoso, poniendo lo más que encuentres en cada nivel. Ya tienes mucha información, así que aprovéchala.

Es importante que esta actividad la realices revisando cada área de tu vida: Física, Intelectual, Emocional, Social y Espiritual (las satisfacciones y sensaciones de que trasciendes lo cotidiano).

Cuando termines tu listado, por favor analiza tus respuestas y pon: una letra " $C$ " si es factible de cambio, " $D$ " si es factible de desarrollo, " $A$ " si es adecuada como está y una "I" si se debe ignorar, por no ser relevante.

Ahora realiza una propuesta de Cambio para cada elemento susceptible a él, con tareas y acciones para lograr las metas (lo que quieres lograr, a largo plazo), lo fragmentas 
Mejora tu calidad de vida y rendimiento académico a través del autoaprendizaje

cada vez más, para cumplirlas diariamente e ir acumulando logros a metas semanales, a mensuales, semestrales y anuales y con un nivel de evolución en aumento a mayor distancia; y, para todos los elementos que se puedan Desarrollar elabora la propuesta similar a la planteada para el cambio, cuando se pueden integrar varios aspectos se hace, cuando no se plantea de manera particular.

Reflexiona: Analiza las respuestas dadas, en función de los elementos que ya has manejado, y escribe una conclusión considerando: ¿Qué necesitas para poder lograrlo? Y establece un compromiso contigo mismo para realizarlo, ponles fechas y resultados esperados en cada una.

ACTIVIDAD 8. LIBERAR LA CARGA con el propósito de lograr un relajamiento y reducir la tensión.

Ya que has realizado un contacto con varias situaciones negativas que en general te generan un malestar que te limita y te congela, llegando a sacarte de la jugada, por ello vas a realizar un ejercicio de revaloración de las situaciones y personas.

+++ Camina por toda la habitación contando hasta 10... y cambias en algo el estilo, la dirección, otros 10 ... cambias velocidad, otros 10 ... das saltitos, otros 10 ... como conejito en cuclillas y poniendo las palmas en el piso... y así pon tres formas más... te levantas y te paras con los pies abiertos... y giras el torso lo más posible suave y lentamente por 33 veces... y te sacudes muy suavemente..., realiza tres respiraciones profundas suaves y lentas (llevando el aire hasta tu vientre), de la siguiente manera: inhalas en 8 tiempos..., retienes $4 . .$. , exhalas $8 . .$. y detienes $4 . .$. , y repites..., cierra tus ojos y percibe que te sientes con más fuerza y control sobre tu cuerpo y tus actividades, dándote mayor calidad de vida...

Reflexiona: Piensa como te sientes y la manera en el que esta actividad física te ayuda a estar en armonía y sentirte a gusto y tranquilo. 
1 Soy resiliente: fortalezco mis habilidades para superar la adversidad

ACTIVIDAD 9. Apreciándome. Con el objetivo de que reconozcas los aspectos sobresalientes que tienes.

+++ En este momento date un tiempo para pensar todas las cosas en las que eres bueno y escoge un adjetivo superlativo que describa cada habilidad, atributo o cualidad (más rápido, más acertado, más agradable), en tu cuaderno anótalos, tratando de hacer la lista más larga posible, luego anota como si ya los tuvieras y enlista aquellos en los que deseas ser muy bueno. Posteriormente lee tu lista en voz alta 6 veces, frente a un espejo y actuando como si fuera real y experimentando al 100\%, repítelo hasta que te la creas.

Reflexiona: Describe cómo te sentiste en la actividad, y cómo los sentimientos variaban en función de las características y cualidades que representabas con los superlativos y sobre todo cuando agregaste aquellas que no tenías en ese nivel pero las anotaste y luego como fueron los sentimientos cuando las leías en voz alta, y ¿al final del ejercicio cómo te sientes?, piensa en la manera en que este ejercicio te ayuda para tus actividades en la vida cotidiana. Y te queda de tarea continuar realizando la lectura al menos una vez al día y ve notando los cambios que se presentan, y cuando sea necesario cambia tu lista e incluye nuevas habilidades o cualidades a trabajar.

ACTIVIDAD 10. EXPRESO MIS Emociones, con el Objetivo de aprender a describir y expresar emociones por medio de conductas deseadas.

+++ Antes de que veas la lista de emociones en tu cuaderno escribe los sentimientos que experimentas con más frecuencia. Realiza una tormenta de Ideas contestando ¿Cuáles son los sentimientos que experimento con más frecuencia? Escríbelos así como te llegan, cuando termines, compáralas con la lista siguiente: Estos suelen ser: Alegría, Odio, Timidez, Inferioridad (sentirme chinche, poca cosa), Tristeza, Satisfacción, Bondad, Resentimiento, Ansiedad, Éxtasis, Depresión, Amor, Celos, Coraje, Miedo, Vergüenza y Compasión, entre otros. Agrega los que sean importantes para ti.

Reflexiona: Puedes preguntarles a tus amigos, para que compares tus resultados. $Y$ compárate contigo mismo, con respecto al inicio, a fin de que veas tu evolución y avance. 
Mejora tu calidad de vida y rendimiento académico a través del autoaprendizaje

Y lo más importante que percibas que estás obteniendo el control sobre éstas y por lo tanto fortaleciendo tus habilidades y relaciones.

ACTIVIDAD 11. DAR y ReCIBIR Afecto, con la finalidad de que vivencies los beneficios relacionados con dar y recibir afecto.

+++ Para la mayoría de las personas, tanto dar como recibir afecto, es asunto muy difícil. Para ayudarte a experimentar la dificultad, usarás un método llamado bombardeo intenso.

Para ello, prueba con diferentes personas decirles de manera clara y cara a cara, cosas que te agradan de ella, diciendo a la persona que: es el foco de atención de todos los sentimientos positivos que tienes hacia ella. Observa tus emociones y la reacción de ella, así como la manera $n$ que tus emociones cambian por las reacciones de ella y anótalas en tu libreta y realiza el mismo ejercicio contigo frente al espejo y haz las notas de tu experiencia.

La intensidad de la experiencia puede variar de diferentes modos: 1) Realízalo cuando la persona te quede de espaldas (más fácil). 2) El impacto es más fuerte cuando te colocas frente y tocas su mano, o su brazo, la miras a los ojos y le hablas directamente. 3) En otro momento puedes escribir una nota, se la entregas y le pides que la lea en silencio.

Reflexiona: Con respecto a cómo los resultados observados en esta actividad pueden ayudarte a mejorar tus relaciones emocionales, siempre cuidando que seas honesto y bajo ninguna circunstancia te aproveches de las necesidades de las personas. Debes ser respetuoso con las personas, por ello es vital que sepas que tus derechos terminan en dónde inician los de las demás personas y justamente trata a los demás como desees ser tratado. Este ejercicio mejora tus relaciones, y te puede ayudar a lograr armonía en los grupos y mejorar la calidad de vida de las personas.

ACTIVIDAD 12. Gimnasia Cerebral. Con el propósito de que actives y estimules las diferentes áreas corticales, para tengas una mayor integración intelectual y personal. 
1 Soy resiliente: fortalezco mis habilidades para superar la adversidad

+++ Elefante: antes de iniciar realiza una autobservación de tus sensaciones, te pones de pie, con ambos pies abiertos más o menos $25 \mathrm{~cm}$, es decir, al ancho de tus caderas, eso te da más equilibrio, levantas tu brazo dominante y lo colocas pegado a tu oreja, luego flexionas suavemente tu cintura, de manera que tu brazo quede lo más cerca del suelo, sin separarlo de la oreja y en esa posición vas a trazar el símbolo de infinito [o], que es un ocho acostado, durante 8 veces y luego inviertes la dirección, por otras 8 veces. Suavemente te levantas y cambias de brazo y repites el proceso. Y realiza una nueva autobservación de tus sensaciones.

Reflexiona: ¿Cómo te sientes? y compáralo con el momento inicial, evalúa los beneficios que te trae este ejercicio, que va más allá de una sola actividad física.

ACTIVIDAD 13. Historia de Mis Recuerdos, con el fin de que analices el impacto que tienen tus recuerdos en tus sentimientos.

Es importante que sepas que: "Los recuerdos son como un trozo de nuestro pasado y los guardamos como verdaderos tesoros, con ellos nos acordamos de momentos felices de nuestra vida. Cada vez que vienen a nuestra mente las personas y los hechos vivimos de nuevo la experiencia en que participamos. Al comentar un recuerdo, revelamos algo de nosotros mismos, de nuestra historia personal. Por ello, también son un aspecto importante para arreglar las cosas que ya pasaron y que nos perturban o incomodan, en virtud de que son como anclas de energías negativas que nos sostienen y amarran; para salir adelante debemos sanar esas relaciones pasadas, sólo cuando sentimos estar atorados ahí".

+++ Ahora en una hoja de tu cuaderno escribe la historia de un recuerdo negativo importante de tu vida, visualízala nítida, a todo color, como si acabara de pasar, observa tus sentimientos. Ahora tómalo como si fuera una fotografía, sácale una copia en blanco y negro, revisa ¿Cómo la ves? ¿Cómo están tus emociones? ¿Bajó la emoción? Saca otra copia con calidad de borrador y analiza tus sentimientos, ¿Han disminuido?, saca otra copia de la copia anterior, que sea apenas legible, ¿Cómo están tus emociones? Saca otras copias hasta que salga vacía y nota ¿Cómo te sientes? Cuando termines obsérvate 
Mejora tu calidad de vida y rendimiento académico a través del autoaprendizaje

y después levántate y sacude esas emociones y ahora evoca un recuerdo muy positivo en que hayas sido muy feliz, anótalo y obsérvate, como es una emoción positiva la dejas ahí.

Reflexiona: Con respecto a los sentimientos que en este momento te han embargado con cada recuerdo, y compáralos con los de cada recuerdo y del presente con relación a cada uno y con de ese recuerdo, ¿en qué momento estaban más fuertes? ¿Cómo te sientes ahora? ¿Cuál es el sentimiento que más deseas experimentar?

ACTIVIDAD 14. SENTIMIENTOS Y JUSTIFICACIONES, con el objetivo de analizar el significado de los sentimientos y las justificaciones que empleas. Así como ayudarte y responsabilizarte de tu propio aprendizaje

+++ Ahora deberás elaborar una conferencia, que debe incluir una introducción, un desarrollo, una propuesta y una conclusión. 10 hacer una investigación documental en textos e internet, en Power Point, con una idea por diapositiva, debes incluir de una a tres imágenes por cada una, con letras de tipo definidas arial, calibri o tahoma, para el titulo tamaño 32, para el desarrollo o cuerpo 28 y para datos remotos 24 como mínimo; sobre el tema de sentimientos y defensas. Debes planearla y estructurarla, y después se la puedes presentar a las personas que desees y les pides que te den ideas de los sentimientos y las defensas, si tienen puntos de vista diferentes, que te hagan comentarios de cómo puedes mejorarla sugiriéndoles que consideren sus reacciones hacia la planeación, la exposición y el contenido de la conferencia; y, entonces tendrás comentarios más honestos. Los comentarios podrás anotarlos en tu cuaderno

Reflexiona: Sobre los elementos que investigaste, cómo van enriqueciendo tu trabajo personal y por otra parte tu experiencia al hablar y exponer estos temas a otras personas.

ACTIVIDAD 15. INVENTARIO DE MI VIDA. Con la finalidad de analizar los valores y los factores personales dentro de un grupo y crear confianza.

+++ En tu cuaderno responde de la manera más rápida, clara y extensa posible, de las siguientes preguntas: 
1 Soy resiliente: fortalezco mis habilidades para superar la adversidad

1. ¿Cuándo me siento totalmente vivo? ¿Cuáles son las cosas, los acontecimientos, las actividades, que me hacen sentir que realmente vale la pena vivir, que es maravilloso estar vivo?;

2. ¿Qué es lo que hago bien? ¿Qué es lo que hago bien para mi propio desarrollo y bienestar? ¿En qué puedo contribuir a la vida de los demás, a fin de que sean mejores?

3. Dada mi situación actual y mis aspiraciones, ¿Qué necesito aprender a hacer?

4. ¿Qué deseos debo convertir en planes? ¿He descartado algunos sueños por no ser realistas y que deba volver a soñar?

5. ¿Qué recursos tengo sin desarrollar o mal utilizados? Estos recursos pueden referirse a cosas materiales, a talentos personales o a amistades.

6. ¿Qué debo dejar de hacer ya?

7. ¿Qué debo empezar a hacer ya?

8. Las respuestas dadas a todas las preguntas anteriores, ¿Cómo afectan a mis planes y proyectos inmediatos para los tres próximos meses, para el próximo año?

Reflexión: Empieza a pensar profundamente en lo que respondiste a la 1ạ pregunta y piensa que impacto tiene con tu vida, y si las respuestas son negativas busca lo que puedes hacer para cambiar, para que experimentes realmente la maravilla de estar vivo, y es un gozo y un compromiso contigo mismo y agradécele a la vida, a tus padres y a ti por darte esta oportunidad y experiméntalo de manera profunda, ya que es el primer paso para todo lo que viene. Toma las notas que necesitas. Y continúa revisando las demás de manera profunda y buscando construir un compromiso de vida contigo, con la sociedad, ya que no estás solo y buena parte de tu crecimiento personal se ve al trabajar para ayudar a los demás, ya que al dar estás recibiendo y esto fortalece y nutre a tu ser, llevándote a un nivel más alto de desarrollo.

ACTIVIDAD 16. Gateo Cruzado. Cuyo objetivo tener mayor fluidez física y verbal, importante en las relaciones humanas. Ambos hemisferios cerebrales se activan $y$ comunican, facilitando el balance de la activación nerviosa. Beneficios: Se forma más redes nerviosas. Prepara el cerebro para un mayor nivel de razonamiento. Es excelente para activar el funcionamiento mente/cuerpo antes de llevar a cabo actividades físicas como el deporte o bailar. 
Mejora tu calidad de vida y rendimiento académico a través del autoaprendizaje

+++ Los movimientos deben efectuarse como en cámara lenta. Con los pies paralelos, al ancho de la cadera, se colocan las manos entrelazadas detrás de la cabeza y se toca con el codo derecho (doblando tu brazo) la rodilla izquierda (levantando y doblando tu pierna). Regresa a la postura inicial. Con el codo izquierdo toca la rodilla derecha lentamente. Regresa a la posición inicial. Repite el ejercicio lo más que puedas mínimo 8 veces cada lado.

Reflexiona: Que percibiste al realizar el ejercicio y pon tu atención en lo que obtienes después de trabajarlo.

LA Motivación es una habilidad fundamental en nuestro desarrollo, en ella se resaltan dos modalidades la intrapersonal en el sentido de que podemos hablar de la capacidad de motivarnos (interna o automotivación) y la interpersonal, que es la capacidad de motivar (a los demás, saber motivar a otras personas).

La definición más simple del término motivar es dar causa o motivo para una cosa. Motivación y motivo son términos estrechamente ligados. Estas palabras derivan del verbo latino 'movere' que significa "moverse", "poner en movimiento" "estar listo para la acción".

Otro aspecto de la motivación es que se trata de "una predisposición general que dirige el comportamiento hacia la obtención de lo que se desea".

La base de toda motivación, es, pues, el deseo. Y la obtención de lo que se desea es, para el grueso de los seres humanos, un sinónimo de felicidad.

Las emociones son una fuente de motivación emocional. Desde un punto de vista técnico, la motivación es la capacidad para enviar energía en una dirección específica con un propósito específico.

Por ello, debes usar tu sistema emocional para catalizar todo el sistema y mantenerlo en funcionamiento. 'Estar motivado es sacar lo que está adentro'. En virtud de que, la 
1 Soy resiliente: fortalezco mis habilidades para superar la adversidad

motivación es el combustible que te permite llevar a cabo lo que te propones. Si estás motivado tienes empuje, dirección y resolución.

Hasta aquí, todo lo descrito puede ser llamado automotivación, para distinguirlo del hecho de motivar a otra persona. En todos los órdenes de la vida la motivación es la clave de cualquier logro y progreso.

ACTIVIDAD 17. EJERCICIO DE MOTIVACIÓN con el propósito de mostrarte que la motivación es interna, pero los incentivos externos pueden iniciar la acción en los humanos.

+++ En tu cuaderno anota cuáles son los elementos o hechos que te proporcionan seguridad a ti, a tu familia en las diferentes áreas: estudio, trabajo y la sociedad (cinco por lo menos en cada área). En seguida realiza preguntas sobre lo que identificaste con tu familia y amigos.

Ahora analiza los conceptos de acuerdo con la teoría de Maslow (1943), quien agrupó las distintas necesidades que debe cubrir cada individuo en cinco niveles de la siguiente forma:

1) Necesidades básicas: se incluyen las necesidades fisiológicas básicas para mantener la vida humana y la supervivencia de la especie. En estas necesidades básicas encuentras las funciones básicas de alimentación, respiración e hidratación así como las necesidades internas para regular la temperatura y el $\mathrm{pH}$.

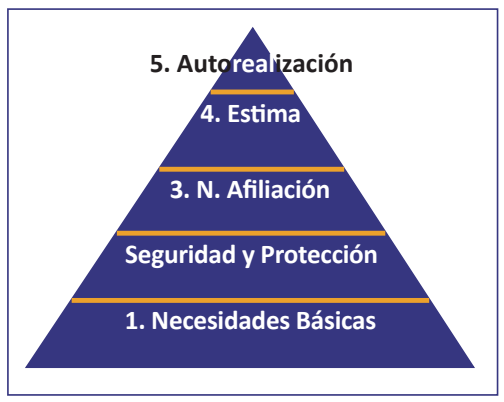


Mejora tu calidad de vida y rendimiento académico a través del autoaprendizaje

Además, se incluyen las necesidades de evitar el dolor, mantener el equilibrio, expulsar los desechos del cuerpo y por supuesto la necesidad de tener relaciones sexuales.

2) Necesidades de seguridad y protección. Una vez que tengas cubiertas y compensadas las necesidades básicas, aparecen las necesidades de seguridad y protección. En estas necesidades, se desarrollan también conceptos que acotan y ponen límites. Piensa por ejemplo en la seguridad física, en la salud de los individuos, en la necesidad de cobertura del empleo, mantenimiento de ingresos u obtención de recursos.

Maslow también encuadra dentro de estas necesidades la seguridad moral, el núcleo familiary la necesidad de la propiedad privada como tal. El concepto de hogary propiedad ligado a las necesidades anteriores, explica gran parte de nuestra organización social. En dónde destacan las necesidades de afiliación y afecto, dando pie a la 3 a categoría.

3) Necesidades de afiliación El desarrollo afectivo de las personas y los niveles relacionales de la sociedad. Encontramos como necesidades de este nivel la asociación, la participación en colectivos, el sentimiento de sentirse aceptado en integrado entre otras.

Este grupo de necesidades se cubren mediante la realización de servicios y prestaciones que incluyen actividades educativas, deportivas, culturales recreativas y de salud. El ser humano por naturaleza siente la necesidad de relacionarse, ser parte de una comunidad, de agruparse en familias, con amistades o en organizaciones sociales. Entre estas se encuentran: la amistad, el compañerismo, el afecto y el amor. Ten presente que estas necesidades surgen de manera colectiva en función de la propia organización social de los colectivos.

4) Necesidades de estima: Maslow sitúa en esta escala la necesidad de atención, aprecio, reconocimiento, reputación, estatus, dignidad, fama, gloria, e incluso dominio sobre el resto de los individuos. Describió dos niveles de estima: alta y baja. La estima alta concierne a la necesidad del respeto de ti mismo, el cuidado de tu yo y las necesidades 
1 Soy resiliente: fortalezco mis habilidades para superar la adversidad

de comunicación interna y autocomprensión que tienes con respecto a ti mismo. Dentro de estos sentimientos propios te encuentras con la confianza, competencia, maestría, logros, independencia libertad y autonomía.

La estima baja concierne a anteponer a las demás personas y atribuir a los demás nuestra valía: si el otro dice que soy valioso es porque así es. Totalmente falso, además las personas con poca valía, para que los otros opinen que es valiosa, se pone de tapete del otro para que le manifieste su afecto, que frecuentemente es falso, dice respetarlos, sólo cuando le atienden y anteponen sus necesidades a las de ellos mismos, así les dice que merecen su respeto.

La carencia de estas necesidades se refleja en una baja autoestima y el complejo de inferioridad, al igual que hay personas que sabiendo que poseen una autoestima pobre, toman una pose de sobre valía y reportan tener mucha autoestima, eso es falso, estas personas caen en el exceso de muchas de las características, devienen de la compensación para encubrir la baja autoestima, por ello es un origen de graves psicopatologías en muchos individuos.

Es importante mencionar que la autoestima es dinámica y si trabajas con estas guías podrás fortalecerla de forma honesta.

5) Autorrealización o autoactualización: Este último nivel es algo diferente y Maslow utilizó varios términos para denominarlo a lo largo de toda su vida tales como "motivación de crecimiento", "necesidad de ser" y "autorrealización". En este nivel se encuentran las necesidades más elevadas, se hallan en la cima de la jerarquía, y a través de su satisfacción, relacionada con un sentido a la vida mediante el desarrollo potencial de una actividad.

Para alcanzar este nivel, necesitas alcanzar y completar hasta el mejor punto posible, el resto de niveles y necesidades inferiores. Es un nivel de trascendencia, de estar disfrutando de cosas sencillas como el paisaje y sentir que estás en paz y unión con la humanidad. 
Mejora tu calidad de vida y rendimiento académico a través del autoaprendizaje

Reflexiona: Sobre la manera en que estás de acuerdo con la satisfacción de tus necesidades y que debes trabajar para llegar a la cúspide de la pirámide, recuerda que sólo tú puedes decidir y trabajar por hacerlo, aunque puedas estar acompañado de amigos y familia, pero cada quién tiene su ritmo, y si llegas primero, eso puede motivarlos. Así mismo, piensa cómo el ejercer la automotivación te fortalece y ayuda a superar situaciones difíciles y a fortalecer tu autonomía.

ACTIVIDAD 18. Momento de MejoraR Mi VIDA, con el propósito de aplicar lo visto y de asumir mi responsabilidad en mi vida.

Suponte que: "Tu médico te ha informado que sólo te queda un año de vida y tú estás convencido de que el diagnóstico es correcto. Describe cómo cambiaría tu vida esta noticia". $Y$ después imagina que te llega un hada de la salud y te ofrece una oportunidad si cambias tus malos hábitos" ¿Tú que cambiarías?

Reflexiona: Sobre los aspectos que te ha movido esta actividad, y piensa "Si deseas cambiar tu vida en esa dirección, ¿Qué te detiene para hacerlo ahora mismo?" Piensa realmente como quieres vivir, y pon manos a la obra, para que lo cumplas, tú tienes la varita mágica, se llama locus de control, si decides que quieres y trabajas para lograrlo tienes el control de tu vida y salud. Que implica realizar actividad psicomotriz, tener alimentación balanceada, usar las neuronas, es decir, aprender algo nuevo y un manejo emocional positivo, que te sientas bien.

ACTIVIDAD 19. Gimnasia Cerebral Sonríe, CANTA y Baila. Con el objetivo de producir endorfinas. Activar la energía corporal, confianza, alegría y acompañamiento.

Sólo debes poner música bailable y dejarte fluir, siguiendo lo que tu cuerpo quiere realizar, eres como el pincel que representa los trazos del pintor y para pintar te desplazas por todo el espacio, con distintos ritmos y movimientos giros, en fin lo que se te apetezca. Algo importante es que sientas y experimentes un gozo profundo de permitirte hacer lo que deseas. 
Reflexiona: En tu cuaderno anota cómo viviste esta grandiosa experiencia, resalta la importancia de la actividad psicomotriz en tu bienestar.

Empatía: ¿Reconoces los sentimientos de las demás personas? ¿Comprendes por qué los demás se sienten así? Esta es la habilidad de 'sentir con los demás', de experimentar las emociones de los otros como si fuesen propias.

Cuando desarrollas la empatía las emociones de los demás resuenan en ti. Sientes cuáles son los sentimientos del otro, cuán fuertes son y qué cosas los provocan. Esto es difícil para algunas personas, pero en cambio, para otras, es tan sencillo que pueden leer los sentimientos tal como si se tratase de un libro.

Es importante aquí hacer una distinción entre la empatía y la simpatía. La simpatía es un proceso que nos permite sentir los mismos estados emocionales que sienten los demás, los comprendamos o no. La simpatía es un proceso puramente emocional, la simpatía es mejor que nada.

Sin embargo, la empatía involucra nuestras propias emociones, y por eso entendemos cabalmente los sentimientos de los demás, porque los sentimos en nuestros corazones además de comprenderlos con nuestras mentes. Y fundamentalmente, la empatía incluye la comprensión de las perspectivas, pensamientos, deseos y creencias ajenos. Para avanzar al siguiente estadio de la conciencia emocional, se requiere verdadera empatía. Ser una persona altamente empática puede tener sus desventajas. Una persona empática es muy consciente de todo un complejo universo de información emocional, a veces dolorosa e intolerable, que otros no perciben.

Las personas que tienen empatía están mucho más adaptadas a las sutiles señales sociales que indican lo que otros necesitan o quieren. Esto los hace mejores en profesiones tales como la enseñanza, las ventas y la administración.

ACTIVIDAD 20. Empatía de Novela. Con el propósito de desarrollar la empatía intrapersonal e interpersonal. 
Mejora tu calidad de vida y rendimiento académico a través del autoaprendizaje

+++ Lee El Fragmento de Tierra de los hombres, Imagina que eres el gobernador general, ponte en su lugar y señala las emociones que siente, esta obra fue escrita por SaintExupèry, quien mientras convalecía en Guatemala de un accidente aéreo grave, que le tuvo postrado en cama durante varios meses. Presenta una vivencia del autor, acaecida en la época que ejerció como piloto de la compañía francesa Aeropostal realizando vuelos de forma regular entre Toulouse, Dakar, Rabat y Cabo Juby. El autor sitúa la acción en Port Etienne, un enclave francés situado en la península de Cabo Blanco, en la frontera con el Sahara Occidental. Rodeado de un extenso desierto, el lugar es casi inexpugnable. Según nos comenta el autor, en Port Etienne sólo hay un fortín, un hangar y una barraca de madera para el alojamiento de los tripulantes de los aviones civiles. La barraca está situada a escasamente un kilómetro del fortín y a pocos metros del hangar. Ante el temor de un ataque de los rebeldes, los aviadores civiles duermen en la barraca con granadas y armamento al pie de su cama. Estas armas se las proporcionan los oficiales del fortín, siguiendo órdenes del Gobierno francés.

Las relaciones entre los oficiales del fortín y los aviadores civiles eran buenas. Tanto unos como otros vivían alejados de la civilización, compartiendo el peligro y la soledad. En muchas ocasiones el gobernador general acudía al hangar y a la barraca de los aviadores a tomar una taza de té. Otras veces eran los aviadores quienes acudían, en calidad de invitados, al fortín. El texto relata precisamente una de esas visitas.

\section{Tierra de los hombres. Saint-Exupéry}

Esta noche hemos cenado en el fortín y el gobernador general nos ha enseñado con orgullo su jardín. Se hizo traer de Francia, en efecto, tres cajas llenas de tierra auténtica que, para llegar, tuvieron que franquear cuatro mil kilómetros. En ellas crecen tres hojas verdes que acariciamos con los dedos, como si fueran joyas. Cuando habla de ellas, el capitán dice: "Es mi parque» y, cuando sopla el viento del desierto, que todo lo seca, bajan el parque al sótano.

+++ En el gráfico grado de emociones experimentadas por el gobernador deberás poner una cruz sobre el número 1 si piensas que el gobernador general no siente una determinada 
emoción; si por el contrario consideras que siente esa emoción en un grado máximo, debes señalar el número 5. Los restantes números -2, 3 y 4-te sirven para identificar los diferentes grados de intensidad, en situaciones intermedias. Si crees que el gobernador general siente otra emoción que no hemos señalado puedes escribir su nombre en la última casilla, marcando también su intensidad.

\begin{tabular}{|l|c|c|c|c|c|}
\hline \multicolumn{6}{|c|}{ Gráfico Grado de Emociones Experimentadas por el Gobernador } \\
\hline Sorpresa & 1 & 2 & 3 & 4 & 5 \\
\hline Alegría & 1 & 2 & 3 & 4 & 5 \\
\hline Ira & 1 & 2 & 3 & 4 & 5 \\
\hline Nostalgia & 1 & 2 & 3 & 4 & 5 \\
\hline Tristeza & 1 & 2 & 3 & 4 & 5 \\
\hline Ternura & 1 & 2 & 3 & 4 & 5 \\
\hline Amor & 1 & 2 & 3 & 4 & 5 \\
\hline Miedo & 1 & 2 & 3 & 4 & 5 \\
\hline Otra & 1 & 2 & 3 & 4 & 5 \\
\hline
\end{tabular}

Reflexión: Justifica el por qué consideras que esta emoción tiene ese nivel. Y luego piensa como si tú fueras el gobernador, trata de entender su contexto y estado emocional y general. Lee el texto y responde nuevamente usando un color diferente para señalar tus respuestas, y analiza si hay cambios y éstos a que se deben. Piensa que a veces para entender a alguien debes tomar su papel. E incluso cuando tienes problemas muy fuertes, se recomienda pensar que le recomendarías hacer a un gran amigo, y funciona, porque distancias tu emoción y puedes pensar con más claridad.

ACtividad 21. Carta a un Pygmalión Negativo. \{Pigmaleón es el nombre de un personaje mitológico, cuyos orígenes se remontan a la Antigua Grecia. De acuerdo al mito, se trataba de un monarca que, tras no encontrar a la mujer ideal para contraer matrimonio, optó por desarrollar esculturas que le permitieran suplir la presencia femenina como compañera de vida. La historia cuenta que Pigmalión terminó enamorándose de una de sus creaciones, bautizada como Galatea. La diosa Afrodita se conmovió ante el deseo de 
Mejora tu calidad de vida y rendimiento académico a través del autoaprendizaje

Pigmalión y le concedió vida a la escultura, transformando a Galatea en un ser humano, http://definicion.de/pigmalion/\#ixzz3vZzrIn99\}. Con el objetivo de ejercitar habilidades de expresión de sentimientos con una actitud empática. Así como reconocer por un lado, qué haces cuando permites que alguien pase sobre ti y cuáles son las consecuencias sobre tus sentimientos y en tus comportamientos.

Todos nos hemos visto obligados en alguna ocasión a tratar con gente y hemos permitido ser tratados como si fuéramos inferiores: que te hayan estado regañando a lo largo de toda tu vida, una persona que continuamente se burla de ti, como un cocodrilo que cuando abre su boca es mejor que te prepares para recibir un mordisco.

+++ Elige una de esas personas y escríbele una carta. Expón en dicha carta tu dolor y tus heridas. Pregúntale sus razones por las que actúa o actuó así contigo, pero no lo ataques ni abuses verbalmente. Expresa tus sentimientos para tratar de entender el comportamiento de esa persona (todo el mundo se comporta de la mejor manera que puede de acuerdo con el conocimiento, la comprensión y la conciencia que cada uno tiene en ese momento). Escribe abierta y honestamente, con buena fe, sin agredir ni humillar, con sinceridad, intentando restablecer líneas de comunicación. Sea cual sea la forma de cómo la persona, a quien diriges la carta, respondería (a la defensiva, acusando, hostil, indiferente, o abierta, deseosa de ofrecerte disculpas, compasiva e igual de deseosa que tú de revitalizar su relación), debes sentirte muy orgulloso de ti mismo/a por haber sido una gran persona con una mente abierta y un gran corazón para escribir la carta. Escribirla te puede servir para reflexionar sobre lo sucedido, ser sincero contigo mismo te puede ayudar a progresar en tu vida. La carta la puedes entregar, o simplemente léela en voz alta para ti y siente como liberas a tu corazón de este peso emocional, y la rompes o la quemas, con mucho cuidado, para evitar accidentes.

Reflexiona: En cómo te has sentido al escribir la carta, así como al terminarla, ¿ has liberado la presión emocional que te mantenía oprimido? Reflexiona sobre los beneficios que te ha dado escribirle la carta a esta persona quien te ha causado daño en el pasado ¿Te ha ayudado a sentirte liberado de esa relación tortuosa? Dado que está persona estaba 
1 Soy resiliente: fortalezco mis habilidades para superar la adversidad

actuando atada a sus circunstancias de odio y rencor, de las que tú posiblemente nada tenías que ver. Especialmente te puede orientar en qué aspectos debes cambiar a fin de hacer que te respetes tú mismo y te respeten los demás. Si te encuentras con personas muy tóxicas o dañinas es sensato alejarte de ellas, sin permitir que te dañen.

ACTIVIDAD 22. ESCALA DE QUINCEY DE EMPATía. El objetivo es descubrir hasta qué punto eres capaz de ponerte en el lugar de otra persona, es decir, deja en pausa todo lo que crees, sientes y considerar un punto de vista diferente.

+++ Imagina cada una de las situaciones e intenta describirla usando palabras de elogio según el respectivo punto de vista del que se trate, y expresa del al diez en qué nivel te es posible ponerte en su lugar, en donde 0 es nada en absoluto y 10 es total y plenamente. Se trata de que si alguna de las situaciones descritas coincide con tu forma de pensar, pasa a la siguiente.

1. El boxeo como una práctica deportiva.

2. El colegio como una escuela de adiestramiento canino.

3. La castidad permanente como una opción virtuosa.

4. La pobreza como un estilo de vida alternativo.

5. El robo como un trabajo estable y bien remunerado.

6. La muerte como el fin de la existencia.

7. El humano como dueño legítimo de todo lo que no es humano.

8. El incesto como un comportamiento socialmente aceptado.

9. El canibalismo como un placer culinario.

10.El asesinato como una de las bellas arte.

Reflexiona: Sobre las situaciones que se te dificultaron más, ¿Con qué situaciones de tu vida se vinculan?, y ¿Si en este momento observas una de las situaciones más difíciles de tu vida, la verías de manera diferente? ¿Cuál fue tu estado de ánimo? Piensa en las ventajas que te trae el ser una persona empática, en tus relaciones interpersonales. $Y$ 
Mejora tu calidad de vida y rendimiento académico a través del autoaprendizaje

de tarea, realiza el intento en el momento en el que te percatas de que se trata de una situación especial y diferente a tu punto de vista.

La importancia de la destreza en las relaciones humanas - habilidades psicosociales no hace falta explicarla. Pero sí conviene definir hasta qué punto son ellas determinantes en todos los aspectos de nuestra vida, o sea, en nuestra salud física y mental, y en nuestro desarrollo social y económico.

Estudios realizados por la Fundación Carnegie, y reafirmados por el Instituto Carnegie de Tecnología, demostraron que aun en ramos técnicos como la ingeniería, cerca del $15 \%$ del éxito financiero de cada profesional se debe al conocimiento técnico, y alrededor del $85 \%$ por ciento se debe a la habilidad en ingeniería humana: a la personalidad y la capacidad para tratar con las personas.

Uno de los principales expertos mundiales en relaciones públicas, Henry Rogers, sostiene: 'Desarrollar sus potencialidades en las relaciones será más importante para su carrera que todo el conocimiento académico que adquiera en la facultad, más importante en la determinación de su futuro como licenciado en arte, en ciencias, doctor en ciencias económicas, en leyes o incluso en filosofía'. Por ello: en la medida en que se relacione sensible y adecuadamente (y sí, incluso cautivadoramente) con las personas y los hechos que enfrente, tanto en su trabajo como en la vida personal, tendrá éxito.

Una vida plena y exitosa se construye gradualmente a partir de una serie de interacciones cotidianas con otros seres humanos, en las que algunos intercambios son vitales y otros triviales; sin embargo, ninguno deja de tener consecuencias. De hecho, el índice del éxito profesional y personal estará determinado, casi infaliblemente, por la forma más o menos eficaz en que maneje dichas interacciones.

Los seres humanos somos muy importantes. En definitiva, sea cual sea el aspecto bajo el que lo miremos, siempre que lo hagamos sanamente, no hay nada en el mundo que sea tan importante como las personas. 
1 Soy resiliente: fortalezco mis habilidades para superar la adversidad

ACTIVIDAd 23. CAmbiar de Punto de VISTA (30 min.) Objetivo: que aprendas a percibir una situación, desde el punto de vista de otra persona.

+++ Esta tarea consiste en que te pongas en lugar del otro, para un intercambio con otra persona o grupo cultural.

10 responde las siguientes preguntas.

Relación con migo mismo: ¿Qué es importante para mí? ¿Qué es lo que me hace único? ¿Cuáles son mis puntos fuertes y débiles? ¿Quién y qué han hecho de mi lo que soy?

$>$ Relación con los otros: ¿Cuáles son mis amistades preferentes (individuos o grupos)? ¿Quiénes son mis héroes, mis modelos? ¿Qué tipo de diferencia tengo y con quién? ¿Cómo se arreglan estas diferencias?

> Relaciones con la sociedad: ¿Cuál es mi papel en la sociedad hoy y mañana? ¿Qué influencia podría ejercer en ella? ¿En qué medida depende mi existencia de la sociedad? ¿Qué podría hacer para mejorarla?

20 lugar, responde las preguntas desde el punto de vista de tu mejor amigo o alguien cercano a ti. Si te es posible pídele que conteste las preguntas de las dos maneras y contrástenlas, para que vean si realmente se habían puesto en el lugar del otro.

Reflexiona: analiza la diferencia entre las reacciones prejuzgadas y las reales. Las consecuencias de nuestros prejuicios (juicios anticipados). Visión actual en nuestro grupo y el cambio experimentado.

ACTIVIDAD 24. PARAFRASEAR. Cuyo objetivo es ejercitar la comunicación empática en las relaciones interpersonales.

+++ Cuando estés con uno de tus mejores amigos: en un $1^{\text {er }}$ momento, en que sostengas plática con él, deberás comentar expresivamente lo que te dice, en un tono similar y expresando tú opinión verdadera. También puedes usar las afirmaciones paradójicas 
Mejora tu calidad de vida y rendimiento académico a través del autoaprendizaje

porque en vez de sentirte mal por algún error cometido, haces gala de ello como algo natural, también se usan cuando alguien se aferra a algo negativo y puedes decirle sí que mal te va, y entonces dice bueno no es para tanto. Toma nota del tipo y fluidez de la comunicación, de tu parte y de la de tu interlocutor.

2 momento: deberás seguir la conversación, practicando la escucha empática, guardando silencio mientras tu compañero hable, sólo reflejando con movimientos corporales o con expresiones breves como: "iaja!", "iohhhh!", "isiiiii!”, "immmmm!", "ihuy que caray!”, si no estás de acuerdo, no debes afirmar: cuando haga pausa parafraseando lo que has entendido de lo que tú compañero te comenta como "hasta donde entiendo tu...", "te refieres a...", o "déjame ver si entendí...", "me dices que...". Toma nota del tipo y fluidez de la comunicación, de tu parte y de la de tu interlocutor.

$3^{\text {er }}$ momento pondrás en práctica simultáneamente los dos actividades, comentar expresivamente y seguir la conversación. Toma nota del tipo y fluidez de la comunicación, de tu parte y de la de tu interlocutor.

Reflexiona: Reflexiona con respecto a las características de los elementos planteados yen cada etapa del ejercicio y de qué manera afectaron a la comunicación. Piensa las reacciones de tu amigo, en cada momento y ve en cual te funciona como un estilo más comunicativo. Esto te da más herramientas para tu comunicación con las diferentes personas.

ACTIVIDAD 25. RESISTIR LA TENTACIón, con el propósito de practicar el negar peticiones sin sentirte mal por ello.

Como te habrás dado cuenta, en primer lugar debes estar bien contigo mismo, debes ser coherente entre lo que quieres-piensas y lo que haces.

A veces los demás te invitan amablemente a hacer cosas o consumir productos apetitosos pero perjudiciales o inadecuados para ti. Frente a estas tentaciones puedes claudicar contra tú íntimo deseo de estar bien y ser fiel a tus valores. 
1 Soy resiliente: fortalezco mis habilidades para superar la adversidad

+++ Medita sobre cada frase y piensa que con quién debes estar bien es contigo mismo, y si te faltas a ti, los demás pasarán sobre ti fácilmente y tú pensarás que: eres un bruto, que lo volviste a hacer y te sentirás devaluado:

-Debería hacer lo que sea para tener contento a todo el mundo.

-Debo ser agradable, para que me amen.

-Es terrible herir o defraudar a los demás, por lo que debo evitarlo a toda costa.

-Es imposible decir «no» sin que se ofendan o sufran los demás.

También podemos ser inhibidos por miedos como:

- Si no hago lo que me pide será agresivo conmigo.

- No le agrada el que yo no haga lo que él quiere.

Reflexiona: Sobre las respuestas que diste a las preguntas, ¿De qué manera te sientes tú en cada situación? Piensa en que en una relación interpersonal lo óptimo es que ambos se sientan bien, ¿En alguna de tus repuestas ocurrió así? Analiza en que otras situaciones se han dado así. Estas deben haber sido muy buenas, ya que ambas partes establecen una buena relación. Pero si esto no es así en cualquier dirección no son relaciones saludables ni satisfactorias, ya que uno gana y el otro pierde.

Lo importante es respetarte a ti mismo, sin ofender a los demás, lo que debes hacer para enfrentar estás situaciones es ser asertivo, es decir, plantear de manera respetuosa y clara lo que quieres hacer, sin ofender a los demás. Como por ejemplo: si te invitan a una fiesta y estás muy cansado o tienes que hacer algo en ese tiempo, puedes decirle: "me encantaría poder asistir, tal vez en otro momento".

Puedes trabajar con alguien de tu confianza.

+++ Por parejas uno genera 3 preguntas o invitaciones a la otra persona quien declinará de manera asertiva y luego intercambian los roles. 
Mejora tu calidad de vida y rendimiento académico a través del autoaprendizaje

Reflexión: Se analiza la dificultad que tuvieron para realizar el ejercicio. Y la importancia de practicar para que en el momento necesario tengas más confianza de negarte a hacer algo que no deseas y peor todavía que te puede perjudicar.

ACTIVIDAD 26. Collage QuiÉn Soy. Con la finalidad de integrar los elementos trabajados durante toda la guía y tu compromiso por tu desarrollo y el uso de tus habilidades y talentos.

+++ Realiza un collage, en el que expreses de manera artística con recortes pegados al cartoncillo ¿Quién soy? y mi plan de desarrollo, de manera que refleje la manera en que te conceptualizas y como te proyectas al futuro. Para ello, requieres una cartulina, revistas que ya no les interese conservar, materiales varios como: diamantina, stickers, colores de madera, de agua, bolígrafos de colores, plumones, pegamento, cintas y tijeras. Cuando lo termines anota en tu libreta lo expresado. Describiendo tus compromisos y toma una foto y pégalo.

Reflexiona: Piensa si algo te faltó y anótalo y asúmelo como un compromiso personal. Con forme pase el tiempo ve si vas cumpliendo con tu plan de vida. $Y$ agregando nuevos proyectos, metas o habilidades.

ACTIVIDAD 27. CAMBiando Mi Película con el propósito de que Integres los elementos trabajados.

+++ Realiza una grabación de la siguiente meditación:

Siéntese de manera cómoda, cierre sus ojos, no cruce manos ni piernas.

Inhale de manera suave profunda y lenta, llevando el aire hasta su vientre..., ahora exhale, suavemente sacando todas las tensiones y toda la negatividad...; realice otra inhalación profunda suave y lenta metiendo paz y tranquilidad..., exhale suavemente todas las tensiones y negatividad...; una vez más realice una inhalación suave profunda y lenta 
1 Soy resiliente: fortalezco mis habilidades para superar la adversidad

trayendo paz y tranquilidad..., exhale suavemente todos los residuos de tensiones y de negatividad...

En su pantalla mental recuerde un momento en el que le hubiera gustado actuar de diferente manera..., Empiece a ver lo que vio en ese momento..., a escuchar lo que escuchó..., y a sentir lo que sintió.

Pregúntese: ¿Qué podría haber hecho que fuera diferente?... Cree películas distintas en su mente, con las alternativas que vaya eligiendo, primero..., vea su imagen en la película... y luego métase en su imagen como si se metiera en una película...

Pregúntese: ¿Estas alternativas me hacen sentir bien?... Si se llegan a realizar ¿Me beneficiaré yo y quienes me rodean?... o ¿Me dañarán?

Puede crear en su cerebro más alternativas y películas diferentes..., escoja por fin una película y su cerebro encontrará las acciones que la hagan realidad... Ahora observe cómo se ve y su entorno en esta nueva película..., escuche cómo se oye, y cómo se oye el entorno... y finalmente observe cómo se sientes y todas las sensaciones que llegan a su cuerpo...

\section{iiiTÚ ELIGES CÓMO QUIERES VIVIR!!!...}

Ahora realice una inhalación suave profunda y lenta, llevando el aire hasta su vientre..., ahora exhale, suavemente haciendo contacto con su cuerpo físico, moviendo lentamente sus manos y pies...; realice otra inhalación profunda suave y lenta fortaleciendo esta nueva experiencia..., exhale suavemente moviendo suavemente sus brazos y sus piernas...; una vez más realice una inhalación suave profunda y lenta fortaleciendo sus recursos para manejar su inteligencia emocional ..., exhale suavemente moviendo suave y lentamente el cuerpo y el cuello, regresando al aquí y ahora... cuando esté listo abra lentamente sus ojos...

Reflexiona: ¿Cómo te sentiste? ¿Lograste seguir toda esta actividad? Piensa que está en tus manos o mejor dicho en ti ser mejor estudiante, profesionista y persona, ahora tienes muchas herramientas para lograrlo. 
Mejora tu calidad de vida y rendimiento académico a través del autoaprendizaje

Para concluir el trabajo de toda esta guía, te pido que reflexiones sobre la manera en la que la escritura te ha ayudado a trabajar con diferentes situaciones, si bien lo realizaste con una instrucción particular. Ahora déjame decirte que es una excelente estrategia para ayudarte a analizar situaciones que te agobian de pronto y no sabes ni por donde, si empiezas a escribir y te dejas fluir sin frenar, sin criticar y sin analizar, sólo fluye con la tinta, con la respiración y deja fluir a tus sentimientos y eso te ayudará a sacar lo que traes atorado, a lo mejor es tan antiguo que ni lo recuerdas, pero está ahí bien guardado, esperando a salir y liberarte de eso. Después puedes si deseas romperlo o quemarlo, eso sí con mucha precaución, usando una gran cacerola o tina metálica, o excelente un asador y haciendo bolitas, para que se pueda quemar más fácil. Esta es una herramienta propuesta para trabajar y hacernos más resilientes. Ya que al sacar todo eso almacenado, nos sentimos liberados y podemos hacer más cosas y podemos apoyar a otros, cuando vemos que andan igual que andábamos y les compartimos las herramientas que hemos usado y nos han ayudado. El ayudar a los demás, es otra forma de fortalecernos compartiendo con los demás.

Ahora que ya terminaste de trabajar con esta guía, te recomiendo que: le des una repasadita a tus notas y respuestas, y observa lo que planteaste y ve si harías de la misma manera o tendrías respuestas diferentes; es más puedes escribirlas con un color diferente, a fin de que en el futuro cuando desees trabajarlo nuevamente puedas notar la manera en que has evolucionado.

Felicidades por todo tu empeño y Gracias por confiar en mí y en toda esta propuesta.

¡Te deseo que vivas bien y feliz!

¡Sigue adelante, hay un largo camino por recorrer! 


\title{
Desarrollo de la comunicación eficiente
}

\author{
J. Alejandra Villagómez Ruíz
}

Como te has dado cuenta el hombre al vivir en sociedad tiene la necesidad de comunicarse, expresar lo que siente y piensa. Estas constantemente comunicando, por lo que comunicar es más que hablar, ya que el $90 \%$ de la comunicación es no-verbal, si hablas, comunicas, si no hablas, comunicas. La comunicación facilita tu convivencia estableciendo relaciones de organización, pautas de conducta y te permite adaptarte al ambiente y al entorno social, también es la herramienta para la adquisición de la cultura. Ya que te sirve para difundir, informar, criticar y conversar. La mayor parte del tiempo estas comunicando.

Se dice que el $90 \%$ de los problemas que afrontan las personas tienen su origen en la comunicación; el $10 \%$ es consecuencia de la limitación humana. Si piensas en algún problema que has tenido, encuentras que, hubo un error en la comunicación. Por lo cual, es importante saber hablar para ser escuchado. En cualquier actividad de interrelación, la forma de como hables y te comuniques será el patrón por medio del cual te acepten o rechacen. El lenguaje el único tipo de conducta social cuya función primaria es la comunicación misma, por lo cual no habría sociedad sin comunicación ya que por medio de ella te unes a cada individuo, grupo e institución.

Es importante que tengas una buena comunicación oral. La cual fortalece tu desarrollo personal, social y académico. Al hablar, debes tener orden, claridad, entusiasmo y persuasión, en pocas palabras comunicación con eficacia es una necesidad. La comunicación oral es el arte de hablar de manera elocuente, saber algo no es lo mismo que saber decirlo. La comunicación oral es la misma en cualquier lugar del universo: Un transmisor envía un mensaje a un receptor valiéndose de un medio o canal de comunicación; y el receptor lo 
Mejora tu calidad de vida y rendimiento académico a través del autoaprendizaje

recibe y entiende y envía una respuesta al transmisor, quien se da por enterado de que hubo comunicación entre ambos. Aunque se realice una comunicación eficaz, el receptor puede estar de acuerdo o en desacuerdo. La comunicación es en sí misma es neutral, independiente de las consecuencias. Los implicados pueden responder de una manera $u$ otra. Lo importante para la mayoría de los seres humanos es que sea clara y entendible, fácil de recordar, que llegue al receptor.

La comunicación es inevitable y más en el sistema de enseñanza; no existe posibilidad de no comunicarse, la comunicación oral está integrada por palabras, voz y acción, y su fin es trasmitir ideas, conocimientos y sentimientos a los estudiantes. Si te expresas y escuchas de manera efectiva, cualquier estrategia de enseñanza-aprendizaje que utilices, será un éxito. Una de las principales habilidades debes desarrollar es la de comunicación efectiva. La comunicación verbal se considera una competencia en la comunicación de ideas y sentimientos. Ayuda a tu autonomía personal, laboral. Siendo una competencia que te permite el desempeño de tu vida académica y profesional. Al tener que comunicarte con tus compañeros, trabajar en equipo, participar en el aula y hacer presentaciones sobre los trabajos realizados, hacer una pregunta a un conferenciante o expresar una opinión en grupo.

El hablar en público es uno de los miedos sociales más comunes, para la mayoría de los estudiantes, hablar en público es aún un reto que cuesta superar, ya que se dan casos de bloqueo, olvido y nervios, los factores que pueden influir negativamente, por ejemplo experiencias negativas, el no tener de experiencias de hablar en público o no ha desarrollado las habilidades para hablar en público. Teniendo pensamientos negativos llevándolo a reacciones de miedo provocando conductas de inseguridad y evitación esto se refleja en pérdidas de tiempo y eficacia en el trabajo en equipo.

Por lo anterior es importante que aprendas a comunicarte conociendo lo que es la comunicación, el proceso de escuchar, los tipos de discursos, la comunicación verbal y la no verbal. 
2 Desarrollo de la comunicación eficiente

Contenido temático

1. Proceso de la Comunicación Oral

2. Relajación y Habilidades para que Enfrentes Situaciones de Estrés

3. Tipos de Discurso y sus Elementos

4. Elaboración y Presentación del Discurso

\section{Objetivo}

Desarrolles y optimices las habilidades en la comunicación oral por medio del fortalecimiento de las habilidades expresivas. Como herramienta para el desempeño académico, personal y profesional.

\section{PROCESO DE LA COMUNICACIÓN ORAL}

ACTIVIDAD 1. Observa a un grupo de personas que estén interactuando y anota todas las maneras de comunicarse. Durante 5 minutos.

¿Hubo comunicación? ¿Observaste que aparte de hablar, movían las manos, el cuerpo y hacían gestos? Por lo que puedes concluir que para comunicarnos usamos tanto la comunicación verbal y no verbal.

Reflexiona: Sobre el papel que juegan tanto la comunicación verbal y no verbal para comunicarnos de manera efectiva y eficiente.

ACTIVIDAD 2. Pídele a un amigo que te grabe realizando tu presentación, preséntate diciendo tu nombre, a qué te dedicas y qué es lo que más te gusta hacer. Antes de revisar la grabación anota lo que tú crees qué hiciste mal y lo qué hiciste bien. Revisa la grabación y anota lo que tú consideres qué haces mal al hablar.

Reflexiona: Debes considerar cómo te paras, mover tus manos al ritmo de lo que dices, tu mirada debe estar al frente todo esto es importante al hablar. ¿Si te percataste de esto?

Pon Énfasis en las Conductas Adecuadas al Hablar en Público. 
Mejora tu calidad de vida y rendimiento académico a través del autoaprendizaje

ACTIVIDAD 3. Gimnasia Cerebral: El Elefante. Aprende las instrucciones del ejercicio y posteriormente sigue las instrucciones. 1. Recarga el oído derecho sobre el hombro derecho y dejar caer el brazo. 2. Mantén la cabeza apoyando tu oreja en el hombro. 3. Extiende bien tu brazo derecho como si fueras a recoger algo del suelo. 4. Relaja tus rodillas, abre tus piernas y reflexiona tu cadera. 5. Dibuja, con todo tu brazo y con la cabeza, tres ochos acostados $(\infty)$ en el suelo empezando por la derecha. 6. Permite que tus ojos sigan el movimiento de tu brazo y que el centro del ocho (donde se cruzan las líneas) quede frente a ti. 7. Si tu ojo va más rápido que tu brazo y tu cabeza, disminuye la velocidad de tu ojo. 8. Repite el ejercicio en la dirección contraria tres veces. 9. Cambia de posición, ahora con el brazo izquierdo y apoyando tu cabeza en el hombro izquierdo. 10. Dibuja tres ochos a la derecha y luego tres a la izquierda. 11. Usar fondo musical.

Reflexiona: ¿Cómo te sientes después del ejercicio? Percibiste un cambio en tu atención, esto se debe a que este ejercicio te permite poner más atención y concentración.

ACTIVIDAD 4. Postura, vista y gestos y muletillas. Al ir leyendo cada uno de los puntos ve practicándolo y obsérvate en el espejo.

1ㅇ La postura es una forma importante de comunicación no verbal, porque te puede dar claves de: confianza, agresividad, ansiedad, temor, inseguridad, rechazo y aburrimiento, entre otros. Con esta puedes darte cuenta si la persona está nerviosa o relajada. El público recibe más información por lo que ve en la cara, manos y gestos que por las mismas palabras.

- Ahora inicia: a) Adopta una postura natural, b) Mantente erguido y relajado. c) La cabeza debes tenerla en alto para dirigir la vista al público. d) Los pies separados más o menos 30 centímetros para tener estabilidad, poder caminar con soltura y paso firme.

e) Las manos las debes mantenerlas libres, de manera natural y así apoyarte en ellas para la comunicación oral. f) También usa el movimiento de la cabeza para reforzar la comunicación. 
2 Desarrollo de la comunicación eficiente

Evita: a) Recargarte en la cadera, es decir pararte sobre una pierna y relajar la otra. b) Cruzar los pies cuando estas de pie. c) Jugar con las manos. d) Meter las manos dentro de las bolsas de la ropa o colocarlas en las caderas. e) Poner los dedos de las manos tensos. f) Pasarte arreglando la ropa. g) Mover los pies constantemente. h) Balancear tu cuerpo. i) Pasarte acomodando el cabello. j) Columpiar los brazos. i) Hacer movimientos repetitivos.

- Observa el video que grabaste: revisa los puntos que anotaste anteriormente respecto a tu presentación y ahora evalúalo de nuevo con esta información ¿Te pudiste dar cuenta de la diferencia al considerar los puntos anteriores?

2 2 Gestos. A través de los gestos se puede proyectar lo que se piensa. Cuando se habla al público se debe apoyar el discurso verbal con la ayuda de los gestos. Ser congruente con los gestos y lo que se dice.

- Colócate frente al espejo y di algo alegre y sé congruente con tus gestos, ahora di algo triste y que tus gestos sean adecuados. ¿Te das cuenta que los gestos apoyan lo que dices?

3을 Contacto visual. El contacto visual es el conjunto de reacciones a través de la mirada con la que se manifiestan los sentimientos, emociones y actitudes. Con la mirada puedes mantener la atención del público. Por ello, es importante que veas al auditorio a la cara y la cuidar la forma como lo miras. Dirígete a cada uno de manera particular, sin mirar sobre sus cabezas ni al piso, paredes, techo o al infinito. La mirada tranquila y serena te permite ver la respuesta de tu público.

- Observa cuando te diriges a las personas si las ves a la cara, y cuando hablas con un grupo te diriges a una sola persona o tienes contacto con todos en diferentes momentos. Ya observaste que importante es tener contacto visual con las personas.

4을 Proxémica: El hecho de moverse por el escenario, adiciona un elemento de convicción a las palabras. El uso que se hace del espacio puede afectar dramáticamente la capacidad para conseguir ciertas metas deseadas de comunicación. Cuando se mueven por el escenario, es importante no perder el contacto, si hay algún material proyectado no te atravieses ya que es muy incómodo para la audiencia. 
Mejora tu calidad de vida y rendimiento académico a través del autoaprendizaje

- Observa cómo se desplazan tus profesores por el salón, y nota los efectos que generan. En cuanto te sea posible, deberás hacer una práctica y observar la atención y los resultados que logres.

50 Muletillas. Son palabras o frases repetitivas y en el fondo innecesarias. Las muletillas pueden ser muy notorias para las personas, pero no para ti, puedes en estos momentos estar cayendo en alguna palabra o frase repetitiva y no te has dado cuenta de ello. Esta muletilla afecta la comunicación.

- Haz una grabación de algún tema y registra las palabreas que repites mucho y obsérvate durante todo un día y ve anotando las muletillas que identificaste en tu grabación. Si ya las tienes identificadas, esto te permitirá hacerlo consciente ya que te estás dando cuenta al usarlas y al hacerlas consientes empezaras a dejar de utilizarlas. Tienes que estar trabajando todos los días, no sólo cuando estas exponiendo un tema.

ACTIVIDAD 5. Habilidades Expresivas (Mapa_1). Estos factores ayudarán a la presentación del discurso siendo: el estilo, la imagen verbal y la credibilidad.

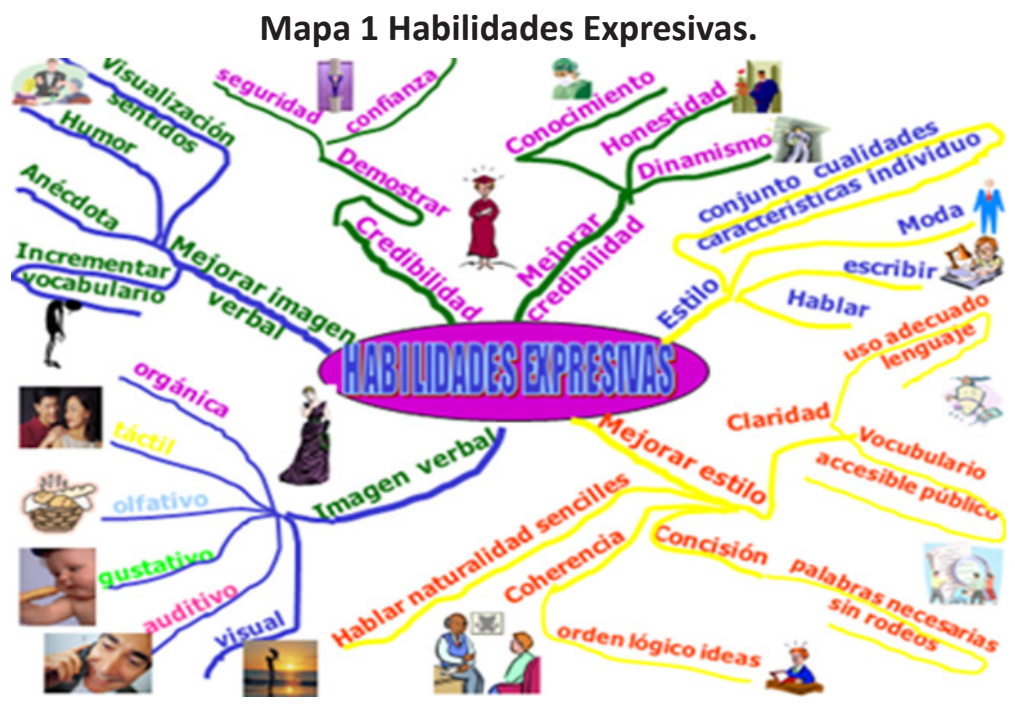


2 Desarrollo de la comunicación eficiente

¿Cuáles son las características de las habilidades expresivas? Como ves, el manejo de estilo, la credibilidad y el uso de la imagen verbal te ayudan a expresarte mejor y lo importante es que lo puedes ir puliendo y mejorando día a día.

1. Estilo es el conjunto de cualidades y características propias de un individuo. Es el sello personal. Que te identifica. Encontrarás estilos en la manera de escribir, de vestir, de hablar. El estilo de hablar lo puedes mejorar al considerar los siguientes elementos: Claridad, Uso adecuado del lenguaje, El vocabulario que uses debe ser accesible al público. Se deben usar las palabras necesarias, sin rodeos ni verborreas, Coherentes, Conservar el orden lógico de las ideas, naturalidad y sencillez al hablar.

2. Imagen verbal es la capacidad que tiene la palabra para describir con una fuerza tal, que conmueve a los sentidos. El lenguaje estimula los sentidos de los oyentes produciendo sensaciones mediante la imaginación. Se presentan diferentes cualidades, como: IMAGeN Verbal VISUAL: "Imagina que estás viendo el mar y ves como las olas van y viene y con ellas un sinfín de colores..."; IMAGen VERBAL AUDITIVA: "estás en el campo y empiezas a oír como cae el agua de la cascada y al mismo tiempo una serie de pájaros empiezan a cantar, las maripositas revolotean a tu alrededor..."; IMAGEN VERBAL DE TIPO GUSTATIVA: "recuerda el sabor del chocolate que hacía tu abuela en la fiesta de tu cumpleaños..."; IMAgen VERBAL OLfativa. "Llegaste a tu casa, entraste y te diste cuenta que tu mama había guisado tu platillo favorito, por el olor que llegaba hasta tu nariz..."; IMAGEN VERBAL TÁCTIL: "recuerda la suave sensación que experimentaste al sentir por tu mano el terciopelo del mueble y que al tocar el borde del cojín te diste cuenta que ya estaba muy viejo..."; e, IMAGEN VERBAL ORGÁNICA: "cuando te subiste en el columpio sentiste una sensación muy fuerte en el estómago y..."

3. Credibilidad. La confianza y la seguridad te permiten reflejar credibilidad en tu auditorio. Las tres características que tiene el orador con credibilidad son: honestidad, conocimiento, y dinamismo, las cuales se refieren a: LA HONESTIDAD debes ser sincero, respetuoso y coherente con el público. Hay veces que el orador aunque maneje muy bien el tema, tendrá alguna duda acerca de alguna pregunta, es válido y aquí puede 
Mejora tu calidad de vida y rendimiento académico a través del autoaprendizaje

ser sincero y decir que no lo sabe pero que lo va a investigar, nunca dar una respuesta falsa; El ConocimiEnTo es el grado de experiencia que tiene el orador sobre el tema. Es más fácil encontrar aceptación si se es experto en el tema; EL DINAMISMO permite manifestar energía y entusiasmo para hablar. Motivando a su público.

- Cuando vayas a conferencias, agradece la oportunidad de poder practicar gratis, tendrás a uno o varios ponentes, analiza los elementos del estilo, de la imagen verbal y del dinamismo, así mismo, percibe el efecto que genera en el público y en ti.

Reflexiona: te diste cuenta que es más fácil y dinámico al tomar en cuenta estos puntos para expresar y comunicarte de una manera más dinámica.

Mapa 2 Expresión Verbal

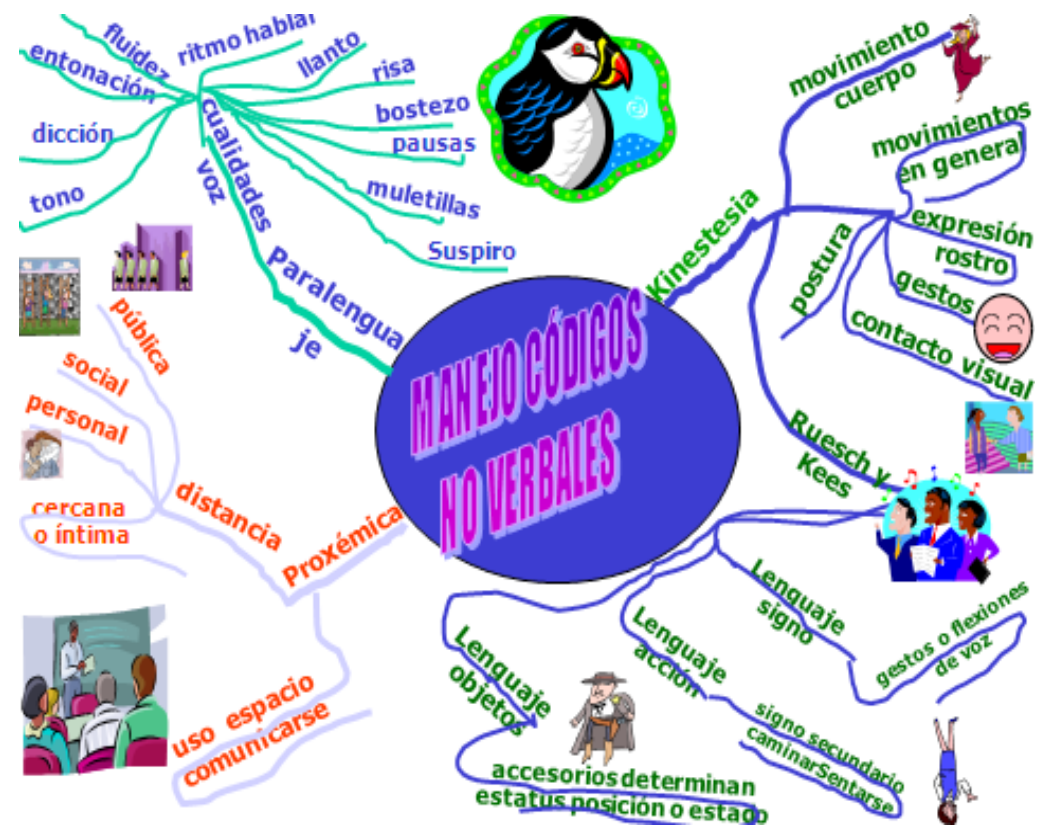


2 Desarrollo de la comunicación eficiente

Mapa 3 Expresión No Verbal

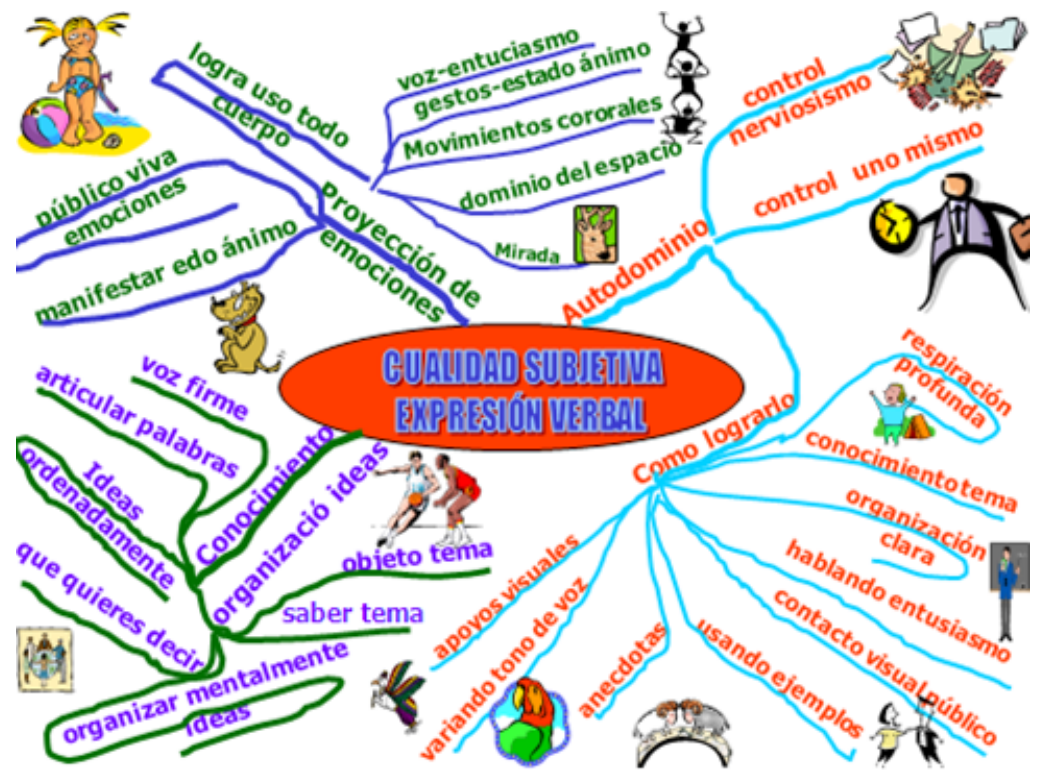

ACTIVIDAD 6. Revisa los siguientes mapas 2 y 3 de: Cualidades subjetivas en la expresión verbal, el manejo de códigos no verbales.

- Ve si estos elementos los manejas cuando te comunicas.

Contesta las siguientes preguntas: ¿Cuáles son las cualidades subjetivas de la expresión verbal? Ya revisaste que el autodominio y la organización de tus ideas, que está dada por el conocimiento que tienes del tema y que son importantes para comunicarte de manera óptima.

¿Qué elementos considera el manejo de códigos no verbales?

Después de revisarlos códigos no verbales: la kinestesia, la proxémica y el paralenguaje, como te puedes dar cuenta todos estos elementos están presentas en el momento de 
Mejora tu calidad de vida y rendimiento académico a través del autoaprendizaje

tener una comunicación con una persona o grupo. Por lo cual hay que estar atentos para fortalecerlas y te puedas comunicar mejor.

Reflexiona: Respecto a la importancia de manejar adecuadamente las cualidades subjetivas así como los códigos no verbales. En virtud de que, el utilizarlos te permite expresarte mejor y tener una comunicación más dinámica.

ACTIVIDAD 7. Manejo De Postura, Gestos Y Contacto Visual Grábate haciendo una presentación, de alguna experiencia de tu vida que haya sido simpática o chusca. Tendrás un minuto y al terminar, retroaliméntate observando el video, tienes que identificar con respecto al manejo erróneo de: postura, gestos, contacto visual. En la hoja de retroalimentación del desarrollo de la comunicación eficiente.

Hoja Retroalimentación del Desarrollo de la Comunicación Eficiente

\begin{tabular}{|c|c|c|c|c|c|c|c|c|c|c|c|}
\hline $\begin{array}{c}\text { Presentación } \\
\text { grabada }\end{array}$ & $\mathrm{M}$ & $\mathrm{PY}$ C & $\begin{array}{c}\mathrm{Ma} \text { y } \\
\mathrm{Pi}\end{array}$ & $\mathrm{Mu}$ & $\begin{array}{c}\mathrm{V} \mathrm{y} \\
\mathrm{Ve}\end{array}$ & $\mathrm{E}$ & $\mathrm{I}$ & $\mathrm{D}$ & $\mathrm{Co}$ & $\mathrm{O}$ & $\mathrm{Cl}$ \\
\hline & & & & & & & & & & & \\
\hline & & & & & & & & & & & \\
\hline
\end{tabular}

Mirada $=\mathrm{M}$ Postura $=\mathrm{P}$ Cadera $=\mathrm{C}$ Manos $=\mathrm{Ma}$ Pies $=\mathrm{Pi}$ Muletillas $=\mathrm{Mu}$ Volumen $=\mathrm{V}$ Velocidad=Ve Énfasis=E Introducción=I Desarrollo=D Conclusión=Co Orden= O Clara=Cl.

El discurso que utilizaste es el discurso de entretenimiento (mapa_4) y en el mapa te darás cuenta de las características de este discurso.

¿Lo habías utilizado alguna vez?, ¿Sí, en qué momento?,

Ya te diste cuenta que es muy fácil ya que tú conoces muy bien el hecho y cuando es muy claro el discurso es más fácil de expresar. 
2 Desarrollo de la comunicación eficiente

\section{Mapa 4 Discurso de Entretenimiento}

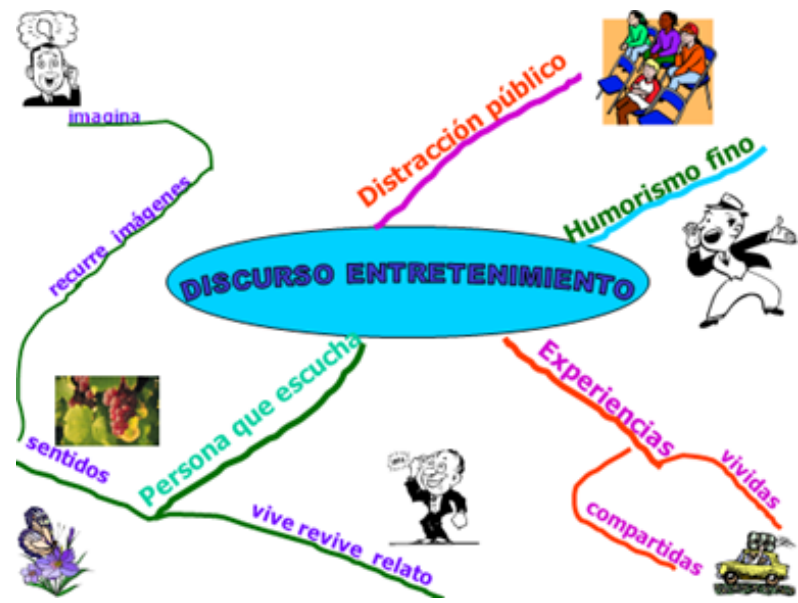

Reflexiona: Sobre la utilidad de este tipo de discurso y que te puede ayudar en tus relaciones sociales. Lo más importante es que tú manejes el tema y que tengas claridad en lo que deseas comunicar.

ACTIVIDAD 8. Relajación. Con el propósito de que te relajes y puedas actuar de manera óptima en tus discursos.

Graba este ejercicio de relajación y sigue las instrucciones: "Cierra tus ojos e inhala 3 veces... Imagina un fondo blanco y visualiza una rosa de color rojo, todavía en capullo... Este capullo de rosa, de color rojo vivo, se coloca en el centro de la pantalla... Entonces los pétalos exteriores se comienzan a abrir de un modo lento y con mucha gracia, y mientras se abre, tus músculos comenzarán a relajarse... A cada pétalo que se abre, se relaja completamente un músculo de tu cuerpo... Primeramente se abre la primera corola de pétalos y se relajan los músculos la cabeza y cara, del cuello y de los hombros... Ahora se abre dulcemente otra corola de pétalos y los músculos de los brazos se hacen cada vez más pesados y completamente relajados... Se abre suavemente otra corola de pétalos rojos y los músculos del pecho, espalda, vientre y de la pelvis, así como los órganos internos se 
Mejora tu calidad de vida y rendimiento académico a través del autoaprendizaje

relajan profundamente... Se abre otra corola de pétalos rojos y los músculos de los muslos, pantorrillas y hasta los pies se relajan perfectamente... En este punto el capullo de rosa roja se ha abierto en todos sus pétalos, y sus músculos están perfectamente relajados. El cuerpo está en una situación de relajamiento total, y un agradable bienestar invade tu mente. Estás tranquilo, sereno, te sientes agradablemente bien y completamente relajado... bien, ahora vas a contar de manera regresiva del 1 al 5 y cundo se llegues al cinco te sentirás bien activo, podas abrir tus ojos y podrás estirarse".

Reflexiona: ¿Cómo te sentiste? Esto lo puedes hacer cuando te sientas estresado y antes de una exposición y con práctica no necesitas ni cerrar los ojos, sólo con una inhalación suave lenta y profunda, evocando este nivel de relajación logrado, lograrás bastante buena relajación y control del estrés.

\section{Aprende el Manejo Adecuado de la Voz.}

\section{ACTIVIDAD 9. Expresión Verbal}

1. Gimnasia Articulatoria. 1 Con la numeración del 1 al 10 la irás diciendo de manera lenta y aumentando la velocidad gradualmente hasta hablar lo más rápido posible y regresando de 10 al 1 de rápido a lo más lento.

2. De la misma manera como el ejercicio anterior, manejaras del volumen con la numeración del 1 al 10 empezando con voz baja y va aumentando el volumen tanto como sea posible y después del 10 al 1, disminuye gradualmente hasta llegar a voz baja.

3. Pronunciando el alfabeto mencionado cada letra, marca exageradamente con la boca frente espejo.

Reflexiona: Estos ejercicios te permiten tener mejor control con la velocidad, volumen de voz y la articulación de las palabras, por lo tanto te expresaras mejor. 


\section{ACTIVIDAD 10. Énfasis.}

1. Es importante hablar con énfasis ya que esto te permite dar más impacto a la comunicación. Le las siguientes oraciones, una primero y luego la otra: Esto no tiene nombre me engañaste" "El ganador del concurso es... Pedro". Lee dando énfasis Primero en la primera palabra, después en la que sigue hasta la última.

2. Busca un artículo de algún tema de un periódico y señala las palabras que creas que contienen las ideas principales, lee el artículo enfatizando las palabras que has seleccionado e intenta usar distintas formas de énfasis. Ahora grábalo y escucha como se escucha según el énfasis que le pongas a cada palabra. Y trata de grabar la noticia del radio y de la tele o de diferentes locutores, a fin de que tengas conciencia del impacto que tienen las noticias, en función al sitio al que se le pone el énfasis.

Reflexiona: Como te das cuenta el énfasis es muy importante cuando te estás comunicando esto le da un impacto a la información.

3. Lee la siguiente lista de sonidos + gestos uno por uno y pon énfasis verbal y gestual como lo expresas con la cara y cuerpo. Ponte frente a un espejo y obsérvate cuando vas diciendo cada palabra.

Cuando pronuncies cada una de las palabras del ejercicio, realizarás el gesto adecuado al contenido de la palabra. Asítu rostro variará su expresión al pronunciar los vocablos «dulce» y "amargo». Por esta razón, el significado gestual de cada palabra, deberá acompañar al sonido. Realiza la lectura de cada segmento numerado (lista de sonidos+gestos), en dónde la segunda palabra deberá poseer más intensidad que la primera, al igual que la tercera tendrá mayor intensidad que la segunda y así consecutivamente. Es decir, vas 'in crescendo', de menos a más. 
Mejora tu calidad de vida y rendimiento académico a través del autoaprendizaje

\section{Lista de Sonidos + Gestos}

1 Bueno Muy bueno Buenísimo

Sobresaliente

2 Malo Muy malo Malísimo Pésimo

3 Dulce Muy dulce Dulcísimo Mielado

4 Amargo Muy amargo Muy amargo

Amarguísimo

5 Feo Muy feo Feísimo Horroroso

6 Lindo Muy lindo Lindísimo Papito

7 Cansado Muy cansado Cansadísimo

Agotado

8 Enojado Muy enojado Enojadísimo Furibundo

9 Alegre Muy alegre Alegrísimo Radiante

10 Triste Muy triste tristísimo Desolado

11 Rápido Muy rápido Rapidísimo Lucífero

12 Lento Muy lento Lentísimo Pesado

13 Limpio Muy limpio Limpísimo Aseado

14 Sucio Muy sucio Sucísimo Marrano

15 Obscuro Muy obscuro Oscurísimo Negro

16 Claro Muy claro Clarísimo Luminoso

17 Ágil Muy ágil Agilísimo Aéreo
18 Alocado Muy alocado Alocadísimo Impulsivo

19 Sereno Muy sereno Serenísimo Plácido 20 Violento Muy violento Violentísimo Impetuoso

21 Duro Muy duro Durísimo Acerado

22 Blando Muy blando Blandísimo Fofo

23 Mentiroso Muy mentiroso Mentirosísimo Falso

24 Recto Muy recto Rectísimo Insobornable

25 Amable Muy amable Amabilísimo Generoso

26 Descortés Muy descortés Descortesísimo Intratable

27 Estupendo Muy estupendo

Estupendísimo Asombroso

28 Grosero Muy grosero Groserísimo Incivil

29 Pensativo Muy pensativo Pensativísimo

Cogitabundo

30 Goloso Muy goloso Golosísimo Glotón

Reflexiona: El énfasis verbal en la articulación y volumen, aunados a los gestos faciales y corporales se integran para darle sentido a lo que comunicas.

\section{ACTIVIDAD 11. Dicción.}

1․ Lee lentamente todos los trabalenguas (Menú de Trabalenguas) en el orden que desees, elige uno memorízalo y repítelo, ahora dilo más rápido y posteriormente grábalo 
y escúchate, y puedes continuar con el resto, eso te ayuda a articular mejor y a manejar palabras de compleja dicción con mayor facilidad.

\begin{tabular}{|c|c|c|}
\hline \multicolumn{3}{|c|}{ Menú de Trabalenguas } \\
\hline $\begin{array}{l}\text { Como quieres que te } \\
\text { quiera, Si el que quiero } \\
\text { que me quiera, No me } \\
\text { quiere como quiero que } \\
\text { me quiera. }\end{array}$ & $\begin{array}{l} \\
\text { Chango chino reflichado } \\
\text { Porque chiflas a la china } \\
\text { Chango chino rechiflado } \\
\text { rechiflador } \\
\text { Que a la changa china } \\
\text { reflichada chiflas } \\
\text { Chango chino rechiflado } \\
\text { rechiflador }\end{array}$ & $\begin{array}{l}\text { El rey de Constantinopla esta } \\
\text { constantinoplizado Consta } \\
\text { que constanza, no lo pudo } \\
\text { desconstantinoplizar } \\
\text { El desconstantinoplizador que } \\
\text { desconstantinoplizare al rey de } \\
\text { constantinopla, } \\
\text { Buen desconstantinoplizador } \\
\text { será }\end{array}$ \\
\hline
\end{tabular}

Reflexiona: El énfasis articulatorio, de volumen más los gestos se unen para que tengas una comunicación con sentido. 
Mejora tu calidad de vida y rendimiento académico a través del autoaprendizaje

ACTIVIDAD 12. Manejo De Postura, Gestos, Contacto Visual Y Expresión Verbal

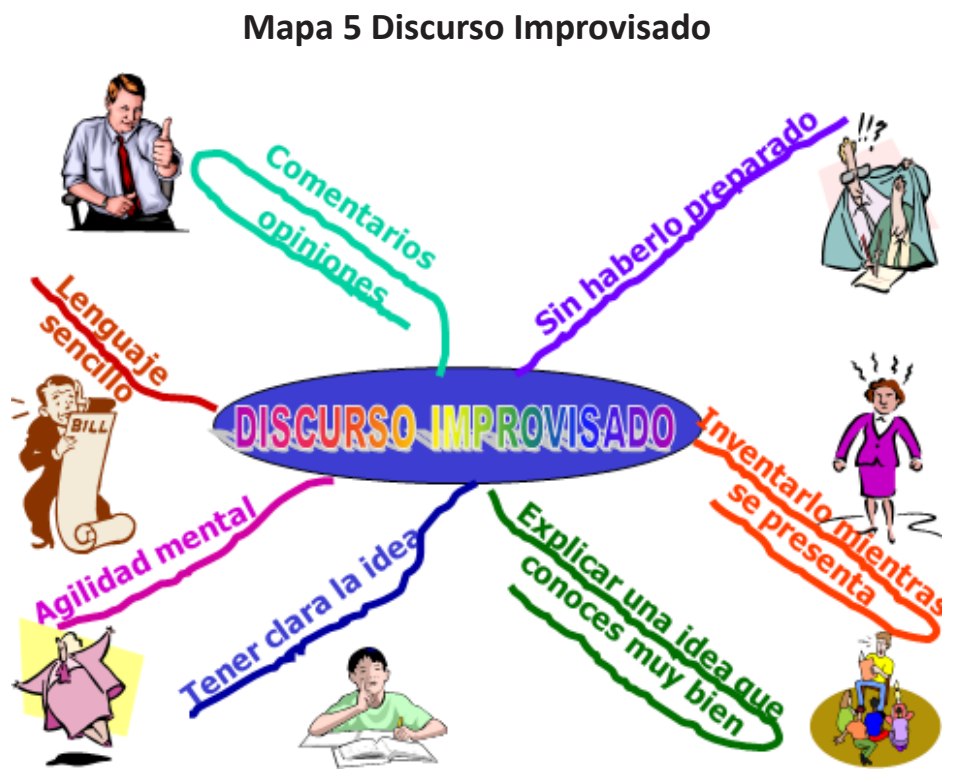

Elige un objeto que tenga algún significado emocional y grábate: menciona porqué es importante el objeto, qué significa ese objeto. Durante un minuto y Al terminar retroaliméntate diciéndole lo que tiene que corregir con respecto de postura, gestos, contacto visual y expresión verbal y el manejo que hiciste con el objeto.

Revisa las características de un discurso improvisado (Mapa_5) y te darás cuenta de nuevo que este discurso lo usas muy frecuente.

Reflexiona: El discurso improvisado lo usas todo el tiempo cuando te comunicas ya que es cuando hablas de tus experiencias y quien las sabe mejor que tú. 
2 Desarrollo de la comunicación eficiente

\section{RELAJACIÓN Y HABILIDADES PARA QUE ENFRENTES SITUACIONES DE ESTRÉS.}

ACTIVIDAD 13. Gimnasia Cerebral: Sentado en una silla, con una postura cómoda, con la columna recta y sin cruzar las piernas: tensa los músculos de los pies, junta los talones, luego las pantorrillas, las rodillas, tensa la parte superior de las piernas, tensa los glúteos, el estómago, el pecho, los hombros, aprieta los puños, tensa tus manos, tus brazos, crúzalos, tensa los músculos del cuello, aprieta tus mandíbulas, tensa el rostro, cerrando tus ojos, frunciendo tu ceño, hasta el cuero cabelludo, una vez que esté todo tu cuerpo en tensión, toma aire, retenlo diez segundos y mientras cuentas tensa hasta el máximo todo el cuerpo, después de diez segundos exhala el aire aflojando totalmente el cuerpo. Cuenta hasta diez y abre tus ojos.

Reflexiona: Esto te permite relajarte, de manera rápida y fácil, y te hace sentir mejor.

ACTIVIDAD 14. Ejercicio Tiki-taka. Platica a alguna persona, algún evento y sólo lo pueden comunicar con la palabra tiki-taka y utilizando todo su cuerpo, cuentas con un minuto. ¿Qué paso cuando sólo podías usar una palabra? ¿Usaste todo tu cuerpo? Puedes grabarte y observar que mueves todo tu cuerpo para expresarte.

Reflexiona: Como ves el utilizar todo tu cuerpo como elemento de la comunicación es tan importante, que ni siquiera son necesarias las palabras, ya que te permite reforzar tu comunicación.

\section{ACTIVIDAD 15. Manejo Del Estrés}

Manejo voluntario de la respiración y automatizarlo para situaciones de estrés. Inhala por la nariz detengan durante 5 segundos y exhala por la boca, esto 3 veces y que sienten cuando lo hacen de manera consciente, cuando se hace esta respiración el cuerpo y las cuerdas bucales se relajan. Cuando estés hablando y te des cuenta que tu voz se oye chillona o cuando te sientas nervioso puedes usar esta respiración. 
Mejora tu calidad de vida y rendimiento académico a través del autoaprendizaje

Reflexiona: Como ya te diste cuenta que este ejercicio libera tus cuerdas bucales y al estar relajadas la voz ya no vibra y tu comunicación se hace con más fluidez. Es una relajación emergente.

Toma Conciencia Del Propio Cuerpo. Primero grábalo: "En primer lugar concentre su atención en el mundo exterior, diciéndose frases como "Soy consciente de cualquier cosa externa como: que está pasando un coche, de que está oscuro, de que mi ropa es azul...". Una vez tome conciencia de lo que le rodea. Dirija su atención a su propio cuerpo y sus sensaciones físicas: "Soy consciente de que tengo frío", "de que tengo hambre", "de mi tensión en el cuello", "del cosquilleo en la planta del pie"... Ahora pase alternativamente de un tipo a otro de conciencia: "Soy consciente de que me duele la cabeza"..., "de que hay excesiva luz"..., "de que la habitación es cuadrada"... Realizando este ejercicio se puede dar cuenta de la diferencia entre el mundo interior y del externo y ser consciente de ello y de controlarlo mejor".

Reflexiona: Este tipo de meditación te permite que puedas identificar tu estrés si viene de algo externo o de algo interno ayudándote a controlarlo.

\section{TIPO DE DISCURSOS Y SUS ELEMENTOS}

ACTIVIDAD 16. Gimnasia Cerebral, El Ocho Perezoso. Vas a dibujar un ocho acostado $(\infty)$ con tu mano dominante, empezando por el centro donde se cruzan las líneas y de ahí hacia arriba a la derecha, cada vez que muevas tu mano ambos ojos deben seguir ese movimiento; si tus ojos tienden a ir más rápido que tu mano, aumenta la velocidad de está; o viceversa, lo importante es que tu ojo siga a tu mano y no la pierda de vista, repite tres veces esta movimiento sobre el mismo ocho que dibujase inicialmente, usando tu ocho inicial cambia a la dirección contraria, repite tres veces este movimiento. Y repites con la mano contraria.

ACTIVIDAD 17. Elementos Estructurales Del Discurso: Introducción, cuerpo o desarrollo y conclusión. Revisa los mapas de los elementos del discurso. 
2 Desarrollo de la comunicación eficiente

Mapa 6 Elementos estructurales del Discurso

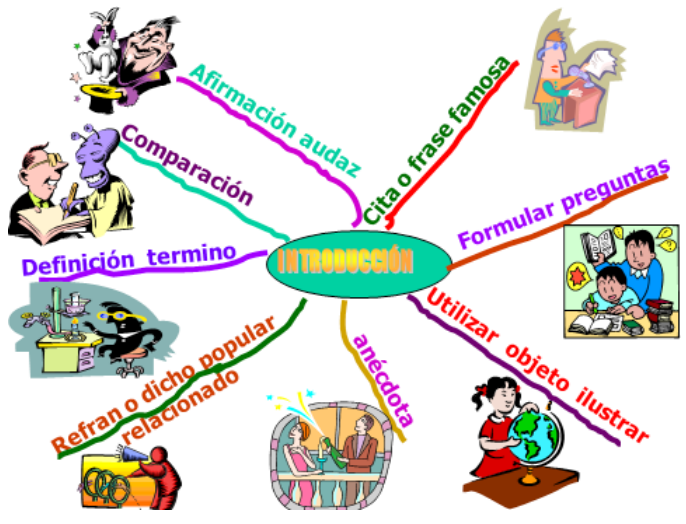

Mapa 8 Cuerpo o Desarrollo

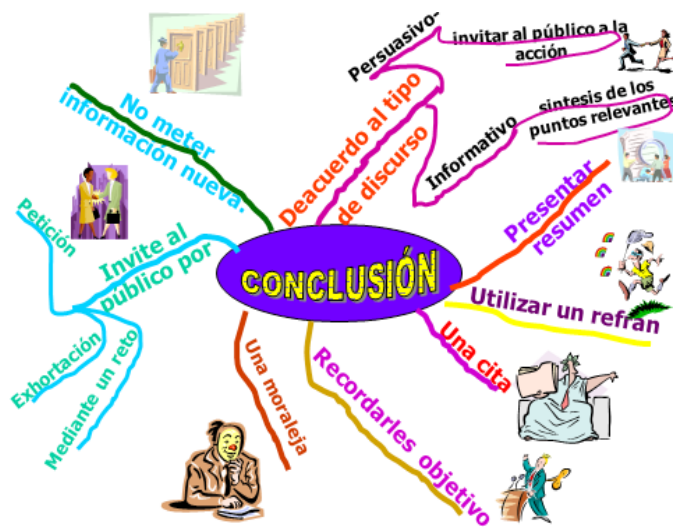

Mapa 7 Introducción

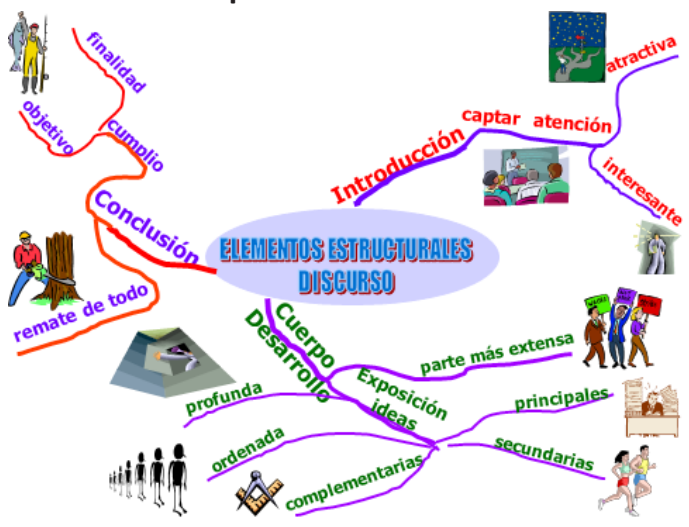

Mapa 9 Conclusión

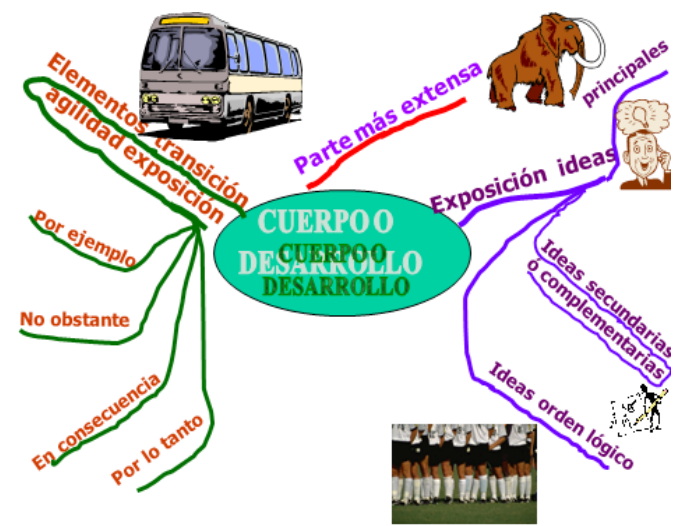

Ahora encuentra Los Elementos Del Discurso Informativo. (Mapas 6, 7,8, y 9).

1o De un periódico elije una nota y subraya la introducción, cuerpo y conclusión, de acuerdo a ti.

2ํo Repásala y dila como si fuera tu nota.

3o Ahora graba tu voz, escucha y donde te atores cambiar la redacción. 
Mejora tu calidad de vida y rendimiento académico a través del autoaprendizaje

4․ Ponte frente a un espejo repite tu exposición.

5o Grábate y retroaliméntate, tomando en cuenta la postura, gestos, contacto visual y expresión verbal y la estructura de tu discurso.

Estas usando un discurso informativo.

Reflexiona: Como puedes ver cada elemento tiene una parte importante para que el discurso tenga coherencia e impacto en los oyentes.

Mapa 10 Discurso Informativo

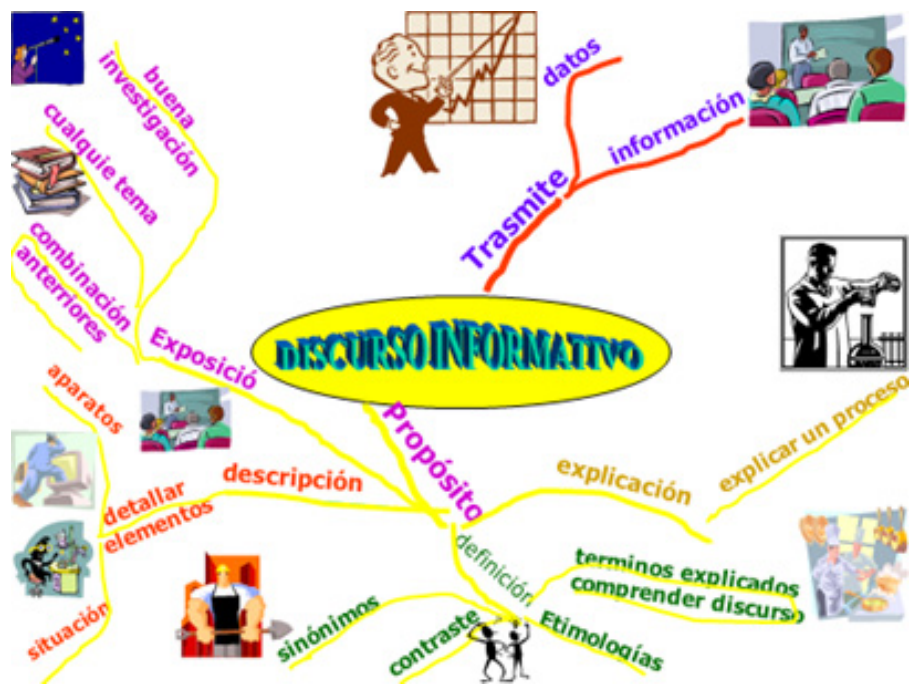

¿Cuántas veces en tu vida has usado un discurso informativo? (Mapa 10).

Es claro que para este tipo de discurso es importante que lo prepares muy bien para que lo puedas disfrutar al exponerlo.

Reflexiona: Con esto te das cuenta que un discurso informativo requiere que el tema sea bien investigado, elaborado con los tres elementos introducción, cuerpo o desarrollo y 
2 Desarrollo de la comunicación eficiente

conclusión. Así como practicar, tomando en cuenta la postura, la vista, el énfasis, y cuidar las muletillas.

ACTIVIDAD 18. Gimnasia Cerebral, Toma ambas orejas por las puntas, tira hacia arriba y un poco hacia atrás, mantenlas así por espacio de veinte segundos, descansa brevemente, repite el ejercicio tres veces.

Reflexiona: Este ejercicio te estimula la escucha.

ACTIVIDAD 19. Manejo De Voz. Hay varios ejercicios que te podrán ayudar a mejorar la voz.

1․ Chiflar para lo cual entonarás cualquier canción para chiflarla.

2 El tararear también es bueno por lo que nuevamente tararea una canción.

Reflexiona: Te darás cuenta con el tiempo que esto te estará ayudando con tu voz.

\section{ACTIVIDAD 20. Del Discurso Improvisado Al Discurso Formal}

1ㅁ Habla sobre un tema que conozcas poco y grábalo.

20 Ahora investiga sobre ese tema y desarróllalo en una hoja de rotafolio.

3o Practica la información durante 15 minutos usando el espejo. Tienes 1 minuto para la exposición con material de apoyo, también aquí grábate. Retroalimenta tu exposición y tu material de apoyo.

Reflexiona: ¿Te diste cuenta de la diferencia de exponer un tema de algo que no sabes? La primera exposición era un discurso improvisado y la segunda exposición es un discurso informativo. Te darás cuenta con el tiempo que esto te estará ayudando a modular y preparar tu voz.

ACTIVIDAD 21. Gimnasia Cerebral Bostezo. Haz la respiración más profunda. Localiza la articulación de la mandíbula abriendo y cerrando la misma, buscando la 
Mejora tu calidad de vida y rendimiento académico a través del autoaprendizaje

articulación con las yemas de sus dedos. Después abriendo la boca jalas aire para provocar el bostezo. Emite un sonido de bostezo profundo y relajado mientras masajeas la articulación de la mandíbula. Este ejercicio se puede repetir de tres a seis veces.

Reflexiona: Esto te ayuda relajar tu boca y tus cuerdas bucales

\section{Mapa 11 Discurso Persuasivo}

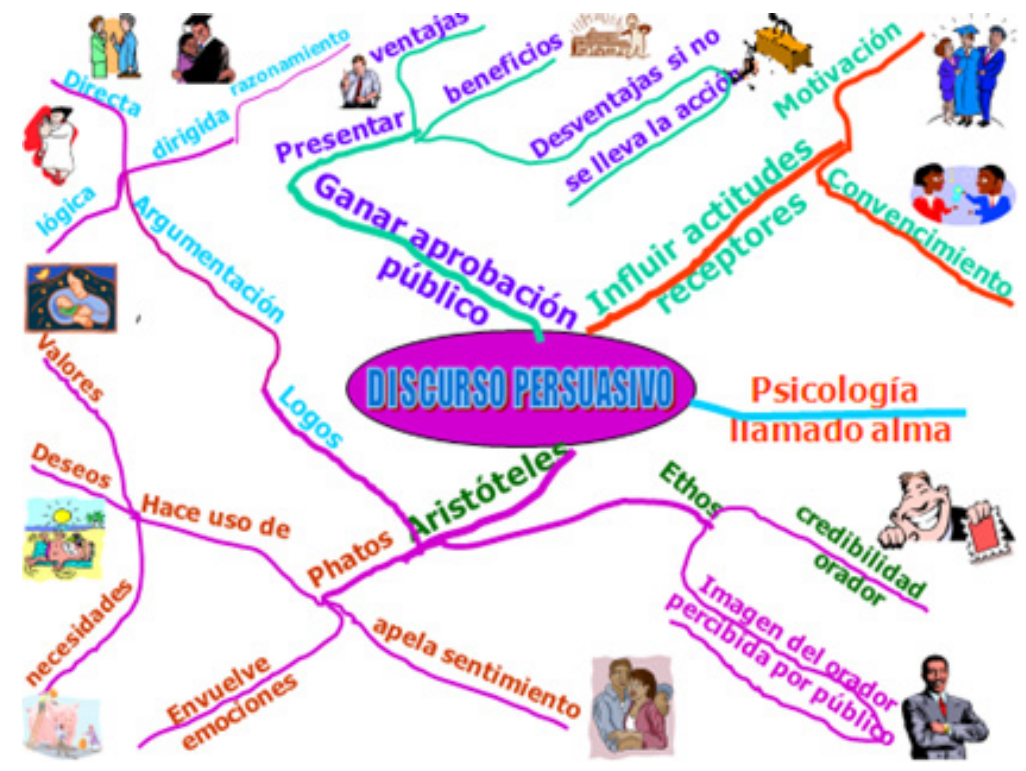

ACTIVIDAD 22. DISCURSO PESUASIVO (Mapa 11). ¿Ya te diste cuenta que no has revisado el discurso persuasivo? Ve algunos anuncios en televisión, radio, revistas e identificaran los modos de persuasión utilizados. Analiza cómo se maneja la persuasión en la publicidad y en la vida diaria. Como influye en la actitud de las personas donde se manejan los deseos, los valores, necesidades utilizando las emociones. ¿Tú has utilizado un discurso persuasivo? ¿Seguro?... Cuando pides permiso para salir, ¿usas este discurso?... 
Mapa 12 Tipos de Discurso

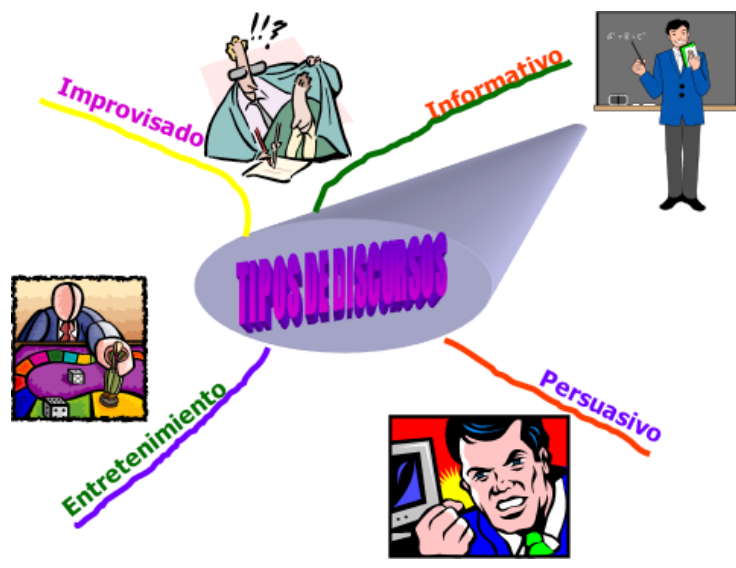

Reflexiona: Este discurso está en todo momento en tu vida y es muy útil para conseguir algo que la gente haga, deje de hacer.

ACTIVIDAD 23. Presentación de los Objetivos del Tipo de Discurso. (Mapa 12 y cuadro Objetivos del tipo de Discurso) Discurso Improvisado Discurso Persuasivo Discurso Entretenimiento. De los discursos que has utilizado, Haz una relación de las características de cada uno.

Como te diste cuenta cada uno cubre diferentes objetivos

\begin{tabular}{|c|l|l|}
\hline \multicolumn{3}{|c|}{ Objetivos de Acuerdo al Tipo de Discurso } \\
\hline OBJETIVO GENERAL & \multicolumn{1}{|c|}{ OBJETIVO ESPECÍFICO } & OBJETIVO FUNCIÓN \\
\hline \multirow{3}{*}{ INFORMAR } & EXPLICAR & $\begin{array}{l}\text { MOSTRAR PROCESO O } \\
\text { FUNCIONAMIENTO }\end{array}$ \\
\cline { 2 - 3 } & DESCRIBIR & DAR CARACTERÍSTICAS \\
\cline { 2 - 3 } & DEFINIR & ACATAR UNO O MÁS TÉRMINOS \\
\cline { 2 - 3 } & EXPONER & PRESENTAR O DAR A CONOCER \\
\hline
\end{tabular}


Mejora tu calidad de vida y rendimiento académico a través del autoaprendizaje

\begin{tabular}{|c|l|l|}
\hline \multicolumn{3}{|c|}{ Objetivos de Acuerdo al Tipo de Discurso } \\
\hline OBJETIVO GeNERAL & \multicolumn{1}{|c|}{ OBJETIVO ESPECÍfICO } & OBJETIVO FUNCIÓN \\
\hline \multirow{2}{*}{ ENTRETENER } & DIVERTIR & $\begin{array}{l}\text { OCUPAR EL TIEMPO EN FORMA } \\
\text { AMENA }\end{array}$ \\
\hline \multirow{4}{*}{ PERSUADIR } & MOTIVAR A LA ACCIÓN & PROMOVER UNA CONDUCTA \\
\cline { 2 - 3 } & CONVENCER / FORMAR & FORMAR OPINIÓN \\
\cline { 2 - 3 } & CONVENCER / REFORZAR & REFORZAR CREENCIAS \\
\cline { 2 - 3 } & CONVENCER / CAMBIAR & $\begin{array}{l}\text { MODIFICAR CONDUCTAS, OPINIONES } \\
\text { O ACTITUDES }\end{array}$ \\
\hline
\end{tabular}

Reflexiona: Es importante que tengas claridad en el objetivo que persigues para dar tu discurso y de ahí la información que vas a impartir. De ahí, vas a podrás elegir y emplear el discurso idóneo.

ACTIVIDAD 24. Planeación, Desarrollo Y Exposición Del Tema

Mapa 13 Planeación del Discurso

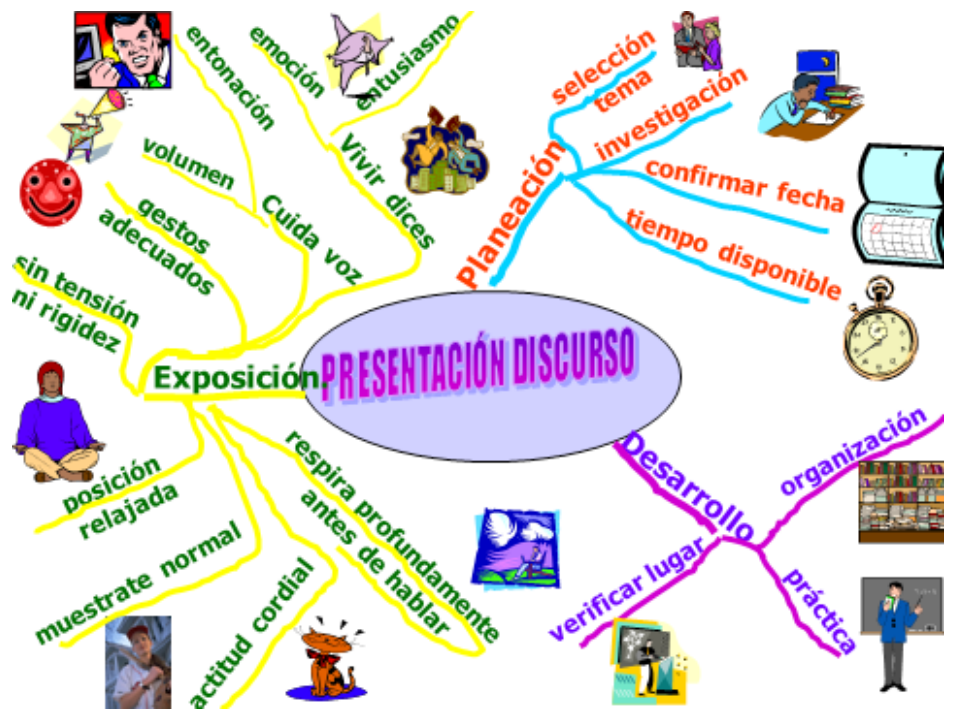


2 Desarrollo de la comunicación eficiente

Cuando vas a preparar un discurso es importante que selecciones el tema, investigues, desarrolles el tema confirmes el tiempo con el que cuentas y la fecha para la presentación. Cuando tengas desarrollado el tema, practicarlo y si te es posible, conoce el lugar y el equipo necesario para la presentación.

- Elige un tema y empieza a investigarlo.

Reflexiona: El que investigues el tema y lo practiques es importante, pero también es muy importante que te ajustes al tiempo del cual dispones.

ACTIVIDAD 25. Realización del Discurso. Ya hecha la revisión del tema, empieza a elaborar el discurso puedes apoyarte en diversos esquemas. El que te presento tiene siete aspectos, que se deben ir respondiendo para una mejor estructura:

\begin{tabular}{|l|l|l|}
\hline \multicolumn{3}{|c|}{ ElEMENTOS QUE INTEGRAN EL DISCURSO } \\
\hline 1 & TEMA & PIENSA EN EL ASUNTO QUE SE DESEAS TRATAR. \\
\hline 2 & PROPÓSITO GENERAL & ¿VAS A INFORMAR, PERSUADIR O ENTRETENER? \\
\hline 3 & PROPÓSITO ESPECÍFICO & $\begin{array}{l}\text { DEFINE CLARAMENTE LA INTENCIÓN QUE TIENES PARA } \\
\text { REALIZAR EL DISCURSO (MENSAJE QUE SE PRETENDES } \\
\text { TRANSMITIR) }\end{array}$ \\
\hline 4 & SECUENCIA LÓGICA & FORMA EN QUE VAS A ORGANIZAR LA INFORMACIÓN \\
\hline 5 & BOSQUEJO DEL TEMA & $\begin{array}{l}\text { ESTABLECE LAS IDEAS PRINCIPALES, SECUNDARIAS Y LAS } \\
\text { SUBDIVISIONES DEL ASUNTO QUE VAS A TRATAR }\end{array}$ \\
\hline 6 & DESARROLLO & $\begin{array}{l}\text { ESCRIBE LAS IDEAS COMPLETAS DE ACUERDO CON CADA } \\
\text { IDEA PRINCIPAL Y SUBDIVISIÓN }\end{array}$ \\
\hline 7 & CIERRE O CONCLUSIÓN & $\begin{array}{l}\text { PLANTEA LAS CONCLUSIONES A LAS QUE HAS LLEGADO } \\
\text { EN TU TRABAJO Y LA VINCULACIÓN CON OTROS TRABAJOS } \\
\text { REVISADOS }\end{array}$ \\
\hline
\end{tabular}

Es importante que tengas una revisión exhaustiva del tema a desarrollar y un conocimiento amplio del tema. Cuando ya tienes el esquema, trabaja el desarrollo completo hasta las conclusiones y anota tus referencias al final. 
Mejora tu calidad de vida y rendimiento académico a través del autoaprendizaje

El bosquejo lo vas haciendo con el esquema donde desarrollas los puntos del tema a presentar, esto sirve para que lleves un orden y manejes una presentación fluida, coherente y clara.

Cuando has desarrollado el cuerpo del discurso, sólo te falta elaborar, el inicio del discurso para motivar al público y el cierre del discurso para dejar claro el mensaje. Finaliza el desarrollo de tu discurso informativo.

Aquí te presento un ejemplo:

\begin{tabular}{|c|c|c|}
\hline \multicolumn{3}{|c|}{ EJEMPLO DE LOS ELEMENTOS QUE INTEGRAN EL DISCURSO } \\
\hline 1 & TEMA & LA COMUNICACIÓN \\
\hline 2 & PROPÓSITO GENERAL & INFORMAR \\
\hline 3 & PROPÓSITO ESPECÍFICO & MEJORAR LA COMUNICACIÓN \\
\hline 4 & SECUENCIA LÓGICA & DEFINICIÓN DE LA COMUNICACIÓN, TIPOS DE DISCURSO \\
\hline 5 & BOSQUEJO DEL TEMA & $\begin{array}{l}\text { A.-. DEFINICIÓN COMUNICACIÓN } \\
\text { ELEMENTOS DE LA COMUNICACIÓN } \\
\text { MODELOS DE COMUNICACIÓN } \\
\text { B TIPOS DE DISCURSO } \\
\text { DISCURSO INFORMATIVO } \\
\text { DISCURSO PERSUASIVO. } \\
\text { DISCURSO ENTRETENIMIENTO. } \\
\text { DISCURSO IMPROVISADO } \\
\text { C. ELEMENTOS DEL DISCURSO } \\
\text { INTRODUCCIÓN } \\
\text { CUERPO O DESARROLLO }\end{array}$ \\
\hline 6 & DESARROLLO & $\begin{array}{l}\text { PARTIR DE LOS PUNTOS ANTERIORES PARA REDACTAR EL } \\
\text { DISCURSO }\end{array}$ \\
\hline 7 & CiERRE O CONCLUSIÓN & $\begin{array}{l}\text { CONOCER LOS ELEMENTOS DEL DISCURSO, LOS OBJETIVOS, } \\
\text { REALIZAR LAS PRÁCTICAS DE HABILIDADES COMUNICATIVAS, } \\
\text { PLANEAR EL DISCURSO, CUIDANDO LOS OBJETIVOS Y LA } \\
\text { INFORMACIÓN A MANEJAR, COHERENTE CON EL TIPO DE } \\
\text { DISCURSO INFORMATIVO, SE CONCLUYÓ QUE SE POSEEN LAS } \\
\text { HABILIDADES Y SEGURIDAD PARA DAR UN BUEN DISCURSO }\end{array}$ \\
\hline
\end{tabular}


Reflexiona: Sobre todos los elementos planteados, que son tus recursos, para la elaboración de tu discurso informativo con una duración de 3 minutos y como material de apoyo haz una presentación en PowerPoint y practica tu presentación, evalúa el impacto que tienes al haber estructurado adecuadamente los elementos en la etapa de planeación y desarrollo del discurso previamente a presentarte a dar la presentación. Especialmente reflexiona sobre los sentimientos que tienes antes de hacer la presentación.

\section{ELABORACIÓN Y PRESENTACIÓN FINAL DEL DISCURSO INFORMATIVO}

Tienes 3 minutos para dar la exposición de tu tema con apoyo de material audiovisual, presentación en PowerPoint. Graba la presentación. Revisa el video y retroaliméntate (formato para evaluación) marcando los aspectos y elementos que incluiste y manejaste asignando un puntaje de 1 a 5, en donde 5 es el mayor, así entre mayor puntaje obtengas, más eficiente será tu comunicación. Además ve en qué has mejorado y compáralo con el primer video.

\begin{tabular}{|l|l|}
\hline \multicolumn{2}{|c|}{ FORMATO PARA LA EVALUACIÓN DE LA PRESENTACIÓN ORAL FINAL } \\
\hline NOMBRE & \\
\hline TEMA & \\
\hline INTRODUCCIÓN & \\
\hline DESARROLLO & \\
\hline CONCLUSIÓN & \\
\hline MANEJO DEL TEMA & \\
\hline VOZ & \\
\hline EMOTIVIDAD & \\
\hline MOVIMIENTO CORPORAL & \\
\hline CONTACTO VISUAL & \\
\hline CREDIBILIDAD & \\
\hline AUTODOMINIO & \\
\hline USO DEL VOCABULARIO & \\
\hline
\end{tabular}


Mejora tu calidad de vida y rendimiento académico a través del autoaprendizaje

\begin{tabular}{|l|l|}
\hline \multicolumn{2}{|c|}{ FORMATO PARA LA EVALUACIÓN DE LA PRESENTACIÓN ORAL FINAL } \\
\hline PRESENTACIÓN PERSONAL & \\
\hline MATERIAL AUDIOVISUAL & \\
\hline OPINIÓN GENERAL & \\
\hline TIEMPO & \\
\hline
\end{tabular}

Reflexión final: Toma en cuenta los puntajes y considera en cuales tienes que trabajar más, así como reconocer cuales son más altos y seguirlos fortaleciendo. Compara viendo el primer video que tomaste al iniciar esta guía y compáralo con el ultimo y menciona que factores mejoraste.

Como te diste cuenta este es un primer paso, a medida que tomes en cuenta los factores que fuiste trabajando se harán un hábito y cada vez será más fácil cuando expongas y lo disfrutaras más.

Además de trabajar y fortalecer los puntos débiles, que son aquellos en que obtuviste puntajes bajos, revisando la guía y seguir realizando los ejercicios para dicción, cuidar los comportamientos adecuados al exponer, y que cuando vayas a exponer realices tu esquema y sigas la secuencia lógica y coherente, amén de manejar una entrada facilitadora y un buen cierre. 


\title{
Tan importante como respirar: La comunicación. Aprende a expresar lo que piensas y sientes
}

\author{
Verónica Lizeth Vences Cruz
}

\begin{abstract}
Ilo largo de la historia el ser humano ha vivido en comunidad; dentro de los grupos sociales se relaciona, comparte experiencias, pensamientos y sentimientos, por lo que se puede decir que la comunicación es fundamental para nuestra especie, ya que ha favorecido nuestra supervivencia y perpetuación en la mayor parte de los ecosistemas del planeta.
\end{abstract}

Planeta en el cual la capacidad de comunicarse efectivamente es cada vez más necesaria, sin embargo la reflexión sobre la comunicación es paradójicamente, escasa. Día a día se pueden ver las consecuencias de la falta de comunicación (en los problemas que surgen en las crisis de amistades, laborales, familiares, matrimoniales o incluso nacionales) y la mayoría de las personas reportan cómo la fuente de todos sus problemas, la dificultad para relacionarse con quienes les rodean.

Por esto, la comunicación es parte fundamental de las relaciones entre los seres humanos, ya que, como bien lo dice Virgina Satir (1991) la comunicación es tan necesaria para la salud, las relaciones interpersonales satisfactorias y la productividad, como la respiración es necesaria para vida" de ahí que es muy importante aprender a comunicarnos adecuadamente.

La comunicación eficaz puede enseñarse y aprenderse, muchas personas pueden pensar que la forma en que el ser humano se comunica es innata, puesto que se comunica desde que nace, sin embargo, es importante aclarar que no lo es; está se aprende a través de la imitación de modelos; que no necesariamente tienen la intención de serlo, o a través del conocimiento de lo que implica este proceso. 
Mejora tu calidad de vida y rendimiento académico a través del autoaprendizaje

Por tal motivo, es muy importante conocer y comprender los elementos básicos del proceso de comunicación, así como otros factores que intervienen en esta, como son: el contexto, la postura corporal, los gestos y la expresión facial y la regulación de la voz, entre otros. Se debe considerar que la comunicación se puede dar de manera verbal y de manera no verbal. Si alguno de estos elementos falla, la comunicación se verá distorsionada y el mensaje que se quiere enviar no será precisamente el que la otra persona reciba y entonces la comunicación se verá afectada.

Es por eso, que tomé la decisión de realizar una guía, que te ayude a desarrollar o fortalecer tus habilidades sociales y de esta manera puedas tener relaciones interpersonales satisfactorias en todas las áreas de tu vida, por medio de una comunicación adecuada.

\section{Temáticas}

1. ¿Qué tan adecuada es mi comunicación?

2. Elementos básicos del proceso de comunicación

3. Es imposible no comunicarme

4. Comunicación verbal y no verbal

5. Niveles de contenido y las relaciones de la comunicación que establezco

6. La puntuación de la secuencia de hechos

7. Interacción simétrica y complementaria

8. ¿Qué es la escucha activa?

9. Importancia de la asertividad y la autoestima en la comunicación.

\section{Objetivo:}

Que al terminar de trabajar con la guía, adquieras las habilidades y competencias de comunicación, y las apliques para tener relaciones sociales satisfactorias.

\section{1. ¿QUÉ TAN ADECUADA ES MI COMUNICACIÓN?}

Antes de comenzar, es importante que sepas qué tan eficaz ha sido tu comunicación hasta el momento, por lo que te pido que realices la autoevaluación que te indicará que tanto 
3 Tan Importante como Respirar: La Comunicación

debes mejorar tu comunicación. Asegúrate de realizarla en un lugar tranquilo, cómodo, con suficiente luz y sin interrupciones.

La autoevaluación se divide en dos partes, encierra en un círculo la respuesta que más se aproxime a tu forma de pensar, debes ser muy sincero con tus respuestas; no hay respuestas buenas o malas, sólo lo que tú piensas. Al finalizar suma tus respuestas por columna, luego saca el total sumando los valores parciales y ve a la tabla final para ver lo que significa.

No te preocupes de si es alta o baja, sólo regresa a trabajar con esta guía y mejorarás.

Escala de Comunicación Adecuada integrada por la autora de esta guía, de las escalas de: Rosemberg, (1964) Escala de Autoestima. Rathus, (1973) Test de Asertividad. Inventario de Ansiedad de Beck y Steer (1988).

\begin{tabular}{|l|c|c|c|c|c|}
\hline \multicolumn{1}{|c|}{ REACTIVOS } & SIEMPRE & $\begin{array}{c}\text { MUCHAS } \\
\text { VECES }\end{array}$ & $\begin{array}{c}\text { ALGUNAS } \\
\text { VECES }\end{array}$ & $\begin{array}{c}\text { MUY } \\
\text { POCAS } \\
\text { VECES }\end{array}$ & NUNCA \\
\hline $\begin{array}{l}\text { 1. Considero que mis opiniones son poco } \\
\text { interesantes }\end{array}$ & $\mathbf{1}$ & $\mathbf{2}$ & $\mathbf{3}$ & $\mathbf{4}$ & $\mathbf{5}$ \\
\hline $\begin{array}{l}\text { 2. Prefiero no hablar con las personas } \\
\text { por temor a decir un comentario “tonto" }\end{array}$ & $\mathbf{1}$ & $\mathbf{2}$ & $\mathbf{3}$ & $\mathbf{4}$ & $\mathbf{5}$ \\
\hline $\begin{array}{l}\text { 3. Si tengo que hablar con alguien pido a } \\
\text { otras personas que me acompañen }\end{array}$ & $\mathbf{1}$ & $\mathbf{2}$ & $\mathbf{3}$ & $\mathbf{4}$ & $\mathbf{5}$ \\
\hline $\begin{array}{l}\text { 4. Prefiero alejarme de las personas } \\
\text { cuando se trata de expresar opiniones }\end{array}$ & $\mathbf{1}$ & $\mathbf{2}$ & $\mathbf{3}$ & $\mathbf{4}$ & $\mathbf{5}$ \\
\hline $\begin{array}{l}\text { 5. Si creo entender lo que una persona me } \\
\text { acaba de decir, me parece redundante } \\
\text { volver a preguntarle para verificar }\end{array}$ & $\mathbf{1}$ & $\mathbf{2}$ & $\mathbf{3}$ & $\mathbf{4}$ & $\mathbf{5}$ \\
\hline $\begin{array}{l}\text { 6. Si me doy cuenta de lo que el otro está } \\
\text { por preguntar, me anticipo y le contesto } \\
\text { directamente, para ahorrar tiempo }\end{array}$ & $\mathbf{1}$ & $\mathbf{2}$ & $\mathbf{3}$ & $\mathbf{4}$ & $\mathbf{5}$ \\
\hline
\end{tabular}




\begin{tabular}{|l|c|c|c|c|c|}
\hline \multicolumn{1}{|c|}{ REACTIVOS } & SIEMPRE & $\begin{array}{c}\text { MUCHAS } \\
\text { VECES }\end{array}$ & $\begin{array}{c}\text { ALGUNAS } \\
\text { VECES }\end{array}$ & $\begin{array}{c}\text { MUY } \\
\text { POCAS } \\
\text { VECES }\end{array}$ & NUNCA \\
\hline $\begin{array}{l}\text { 7. Cuando algo no me parece prefiero no } \\
\text { expresarlo }\end{array}$ & $\mathbf{1}$ & $\mathbf{2}$ & $\mathbf{3}$ & $\mathbf{4}$ & $\mathbf{5}$ \\
\hline $\begin{array}{l}\text { 8. Antes de hablar con alguien me siento } \\
\text { nervioso }\end{array}$ & $\mathbf{1}$ & $\mathbf{2}$ & $\mathbf{3}$ & $\mathbf{4}$ & $\mathbf{5}$ \\
\hline $\begin{array}{l}\text { 9. Al hablar con alguien me dan muchas } \\
\text { ganas de orinar }\end{array}$ & $\mathbf{1}$ & $\mathbf{2}$ & $\mathbf{3}$ & $\mathbf{4}$ & $\mathbf{5}$ \\
\hline $\begin{array}{l}\text { 10. Cuando algo me molesta suelo } \\
\text { reclamar y a veces hasta insultar }\end{array}$ & $\mathbf{1}$ & $\mathbf{2}$ & $\mathbf{3}$ & $\mathbf{4}$ & $\mathbf{5}$ \\
\hline $\begin{array}{l}\text { 11. Miconversación resulta desagradable } \\
\text { para los demás }\end{array}$ & $\mathbf{1}$ & $\mathbf{2}$ & $\mathbf{3}$ & $\mathbf{4}$ & $\mathbf{5}$ \\
\hline $\begin{array}{l}\text { 12. Cuando sostengo una conversación } \\
\text { con alguien siento que no puedo respirar }\end{array}$ & $\mathbf{1}$ & $\mathbf{2}$ & $\mathbf{3}$ & $\mathbf{4}$ & $\mathbf{5}$ \\
\hline $\begin{array}{l}\text { 13. Pienso que a nadie le importa lo que } \\
\text { digo }\end{array}$ & $\mathbf{1}$ & $\mathbf{2}$ & $\mathbf{3}$ & $\mathbf{4}$ & $\mathbf{5}$ \\
\hline $\begin{array}{l}\text { 14. Evito ir solo a lugares donde habrá } \\
\text { personas }\end{array}$ & $\mathbf{1}$ & $\mathbf{2}$ & $\mathbf{3}$ & $\mathbf{4}$ & $\mathbf{5}$ \\
\hline $\begin{array}{l}\text { 15. Cuando tengo que hablar con alguien } \\
\text { que no conozco me sudan las manos }\end{array}$ & $\mathbf{1}$ & $\mathbf{2}$ & $\mathbf{3}$ & $\mathbf{4}$ & $\mathbf{5}$ \\
\hline $\begin{array}{l}\text { 16. Cuando tengo que hablar con alguien } \\
\text { que no conozco me sonrojo }\end{array}$ & $\mathbf{1}$ & $\mathbf{2}$ & $\mathbf{3}$ & $\mathbf{4}$ & $\mathbf{5}$ \\
\hline $\begin{array}{l}\text { 17. Para mí es muy importante quedar } \\
\text { bien con los demás }\end{array}$ & $\mathbf{1}$ & $\mathbf{2}$ & $\mathbf{3}$ & $\mathbf{4}$ & $\mathbf{5}$ \\
\hline $\begin{array}{l}\text { 18. Me cuesta acercarme a los demás } \\
\text { 19. Cuando hablo con alguien siento que } \\
\text { mi frecuencia cardiaca se acelera }\end{array}$ & $\mathbf{1}$ & $\mathbf{2}$ & $\mathbf{2}$ & $\mathbf{4}$ & $\mathbf{5}$ \\
\hline $\begin{array}{l}\text { 20. Al sostener una conversación siento } \\
\text { como se tensan mis músculos }\end{array}$ & $\mathbf{1}$ & $\mathbf{2}$ & $\mathbf{3}$ & $\mathbf{4}$ & $\mathbf{5}$ \\
\hline $\begin{array}{l}\text { 21. Soy malo al momento de expresar } \\
\text { mis sentimientos }\end{array}$ & $\mathbf{1}$ & $\mathbf{3}$ & $\mathbf{4}$ & $\mathbf{5}$ \\
\hline
\end{tabular}


3 Tan Importante como Respirar: La Comunicación

\begin{tabular}{|c|c|c|c|c|c|}
\hline REACTIVOS & SIEMPRE & $\begin{array}{l}\text { MUCHAS } \\
\text { VECES }\end{array}$ & $\begin{array}{l}\text { ALGUNAS } \\
\text { VECES }\end{array}$ & $\begin{array}{l}\text { MUY } \\
\text { POCAS } \\
\text { VECES }\end{array}$ & NUNCA \\
\hline $\begin{array}{l}\text { 22. Cuando hablo con alguien no puedo } \\
\text { mantenerme quieto }\end{array}$ & 1 & 2 & 3 & 4 & 5 \\
\hline $\begin{array}{l}\text { 23. Cuando quiero expresar algo espero } \\
\text { a que me lo pregunten }\end{array}$ & 1 & 2 & 3 & 4 & 5 \\
\hline $\begin{array}{l}\text { 24. Evito hablar con personas atractivas } \\
\text { o con autoridad }\end{array}$ & 1 & 2 & 3 & 4 & 5 \\
\hline $\begin{array}{l}\text { 25. Yo cometo más errores que los } \\
\text { demás }\end{array}$ & 1 & 2 & 3 & 4 & 5 \\
\hline 26. Evito hablar delante de otros & 1 & 2 & 3 & 4 & 5 \\
\hline $\begin{array}{l}\text { 27. Al hablar con alguien suelo } \\
\text { interrumpir para dar mi punto de vista }\end{array}$ & 1 & 2 & 3 & 4 & 5 \\
\hline $\begin{array}{l}\text { 28. Siempre que alguien habla conmigo } \\
\text { muestro interés a lo que me está } \\
\text { diciendo }\end{array}$ & 1 & 2 & 3 & 4 & 5 \\
\hline $\begin{array}{l}\text { 29. He dudado en aceptar citas por } \\
\text { temor a no saber qué hacer. }\end{array}$ & 1 & 2 & 3 & 4 & 5 \\
\hline $\begin{array}{l}\text { 30. Cuando tengo que hablar con alguien } \\
\text { fumo tabaco para relajarme }\end{array}$ & 1 & 2 & 3 & 4 & 5 \\
\hline $\begin{array}{l}\text { 31. Al platicar con alguien se me seca la } \\
\text { boca constantemente }\end{array}$ & 1 & 2 & 3 & 4 & 5 \\
\hline $\begin{array}{l}\text { 32. Paso un mal rato cuando digo que } \\
\text { "no" }\end{array}$ & 1 & 2 & 3 & 4 & 5 \\
\hline $\begin{array}{l}\text { 33. Cuando hablo con alguien siento } \\
\text { que mis movimientos son torpes y sin } \\
\text { sentido }\end{array}$ & 1 & 2 & 3 & 4 & 5 \\
\hline \multicolumn{6}{|l|}{ Sumatorias Parciales } \\
\hline SUMATORIA TOTAL & & & & & \\
\hline
\end{tabular}


Ahora responde la segunda parte de la autoevaluación, recuerda ser muy sincero en tus respuestas.

\begin{tabular}{|l|c|c|c|c|c|}
\hline \multicolumn{1}{|c|}{ REACTIVOS } & NUNCA & $\begin{array}{c}\text { MUY } \\
\text { POCAS } \\
\text { VECES }\end{array}$ & $\begin{array}{c}\text { ALGUNAS } \\
\text { VECES }\end{array}$ & $\begin{array}{c}\text { MUCHAS } \\
\text { VECES }\end{array}$ & SIEMPRE \\
\hline $\begin{array}{l}\text { 1. Cuándo alguien pregunta algo y sé la } \\
\text { respuesta le contesto }\end{array}$ & $\mathbf{1}$ & $\mathbf{2}$ & $\mathbf{3}$ & $\mathbf{4}$ & $\mathbf{5}$ \\
\hline $\begin{array}{l}\text { 2. Cuándo platico con otra persona } \\
\text { pongo atención a todos los detalles de lo } \\
\text { que me dice }\end{array}$ & $\mathbf{1}$ & $\mathbf{2}$ & $\mathbf{3}$ & $\mathbf{4}$ & $\mathbf{5}$ \\
\hline $\begin{array}{l}\text { 3. Suelo hablar con muchas personas } \\
\text { durante el día }\end{array}$ & $\mathbf{1}$ & $\mathbf{2}$ & $\mathbf{3}$ & $\mathbf{4}$ & $\mathbf{5}$ \\
\hline $\begin{array}{l}\text { 4. Suelo dar mi opinión cuando mi familia } \\
\text { platica }\end{array}$ & $\mathbf{1}$ & $\mathbf{2}$ & $\mathbf{3}$ & $\mathbf{4}$ & $\mathbf{5}$ \\
\hline $\begin{array}{l}\text { 5. Suelo dar mi opinión cuando hablo con } \\
\text { un maestro de mi escuela }\end{array}$ & $\mathbf{1}$ & $\mathbf{2}$ & $\mathbf{3}$ & $\mathbf{4}$ & $\mathbf{5}$ \\
\hline $\begin{array}{l}\text { 6. Suelo dar mi opinión cuando me } \\
\text { encuentro con mis compañeros }\end{array}$ & $\mathbf{1}$ & $\mathbf{2}$ & $\mathbf{3}$ & $\mathbf{4}$ & $\mathbf{5}$ \\
\hline $\begin{array}{l}\text { 7. Mientras escucho a otra persona, } \\
\text { me pongo a pensar en lo que le voy a } \\
\text { responder }\end{array}$ & $\mathbf{1}$ & $\mathbf{2}$ & $\mathbf{3}$ & $\mathbf{4}$ & $\mathbf{5}$ \\
\hline 8. Tengo muchos amigos & $\mathbf{1}$ & $\mathbf{2}$ & $\mathbf{3}$ & $\mathbf{4}$ & $\mathbf{5}$ \\
\hline $\begin{array}{l}\text { 9. Cuando necesito algo inmediatamente } \\
\text { lo expreso }\end{array}$ & $\mathbf{1}$ & $\mathbf{2}$ & $\mathbf{3}$ & $\mathbf{4}$ & $\mathbf{5}$ \\
\hline $\begin{array}{l}\text { 10. Siempre que alguien habla conmigo } \\
\text { muestro interés a lo que me está diciendo }\end{array}$ & $\mathbf{1}$ & $\mathbf{2}$ & $\mathbf{3}$ & $\mathbf{4}$ & $\mathbf{5}$ \\
\hline $\begin{array}{l}\text { 11. Soy capaz de sostener una } \\
\text { conversación con alguien }\end{array}$ & $\mathbf{1}$ & $\mathbf{2}$ & $\mathbf{3}$ & $\mathbf{4}$ & $\mathbf{5}$ \\
\hline $\begin{array}{l}\text { 12. Cuando algo no me parece lo expreso } \\
\text { de manera respetuosa }\end{array}$ & $\mathbf{1}$ & $\mathbf{2}$ & $\mathbf{3}$ & $\mathbf{4}$ & $\mathbf{5}$ \\
\hline
\end{tabular}


3 Tan Importante como Respirar: La Comunicación

\begin{tabular}{|l|c|c|c|c|c|}
\hline \multicolumn{1}{|c|}{ REACTIVOS } & NUNCA & $\begin{array}{c}\text { MUY } \\
\text { POCAS } \\
\text { VECES }\end{array}$ & $\begin{array}{c}\text { ALGUNAS } \\
\text { VECES }\end{array}$ & $\begin{array}{c}\text { MUCHAS } \\
\text { VECES }\end{array}$ & SIEMPRE \\
\hline $\begin{array}{l}\text { 13. Mientras estoy escuchando, digo } \\
\text { cosas como iAjá!, o iEntiendo!, para } \\
\text { hacerle saber a la otra persona que le } \\
\text { estoy prestando atención }\end{array}$ & $\mathbf{1}$ & $\mathbf{2}$ & $\mathbf{3}$ & $\mathbf{4}$ & $\mathbf{5}$ \\
\hline $\begin{array}{l}\text { 14. Me gusta llamar la atención } \\
\begin{array}{l}\text { 15. Si no comprendo lo que una persona } \\
\text { está diciendo, hago las preguntas } \\
\text { necesarias hasta entenderla }\end{array}\end{array}$ & $\mathbf{1}$ & $\mathbf{2}$ & $\mathbf{3}$ & $\mathbf{4}$ & $\mathbf{3}$ \\
\hline $\begin{array}{l}\text { 16. Siempre tengo algo interesante que } \\
\text { decir }\end{array}$ & $\mathbf{1}$ & $\mathbf{2}$ & $\mathbf{3}$ & $\mathbf{4}$ & $\mathbf{5}$ \\
\hline $\begin{array}{l}\text { 17. Después de hablar con alguien suelo } \\
\text { resumir el mensaje que me acaban de } \\
\text { transmitir }\end{array}$ & $\mathbf{1}$ & $\mathbf{2}$ & $\mathbf{3}$ & $\mathbf{4}$ & $\mathbf{5}$ \\
\hline Sumatorias Parciales & & & & & \\
\hline SUMATORIA TOTAL & & & & & \\
\hline
\end{tabular}

Suma ambos puntajes totales y después revisa lo siguiente, si tu puntaje fue de:

211 o más: tienes un buen manejo de la comunicación, sin embargo, es importante reforzar algunos aspectos.

171 y 210: Debes trabajar para mejorar en algunas áreas de la comunicación.

125 a 170: Debes trabajar arduamente para mejorar tus habilidades de comunicación.

Menos de 124: Es muy importante realizar cambios en tu forma de comunicarte con los demás, para tener relaciones satisfactorias.

Una vez realizada la autoevaluación, es momento de comenzar a desarrollar o fortalecer tus habilidades de comunicación: :) 
Mejora tu calidad de vida y rendimiento académico a través del autoaprendizaje

A continuación te presento algunas definiciones de comunicación:

De acuerdo con León (2002) la comunicación es el proceso mediante el cual dos o más personas intercambian conocimientos y experiencias. Este intercambio se realiza fundamentalmente a través de símbolos, señales y signos ya sean verbales o no verbales; por su parte, González (2002) la define como la interacción continúa entre dos o más personas, mediante el uso de símbolos con el propósito de influir (modificar) en el área de los pensamientos, sentimientos o acciones; mientras que para Pascual (2006) la comunicación es el proceso por medio del cual se transmiten significados de una persona a otra, de manera que, es el intercambio por medio de palabras, símbolos o mensajes de tal forma, que un miembro de la organización comparte el sentido y el entendimiento con otro y finalmente Rangel (2000) afirma la comunicación es un proceso (serie de fases de un fenómeno) por medio del cual emisores y receptores de mensajes interactúan en un contexto social dado.

Como puedes notar estas definiciones tienen características comunes que se complementan entre sí. Por lo que podemos decir que la comunicación es un proceso, ya que requiere de una serie de pasos para que se pueda realizar de manera exitosa; mediante dicho proceso se transmiten conocimientos, experiencias, sentimientos y pensamientos, a través de símbolos, señales y signos que pueden ser verbales y/o no verbales.

Además de que, no es una tarea opcional a la que podamos dejar de lado libremente, puesto que nuestra misma naturaleza social nos impulsa necesariamente a ella. Debido a que, es totalmente necesaria para nuestro bienestar psicológico. Pero no se reduce solamente a una necesidad, sino que es el medio para satisfacer muchas otras (Marroquín, \& Villa, 1998).

;: Te propongo un ejercicio para que percibas mejor este proceso. Elige a una persona de tu alrededor para conversar, no hace falta que sea de mucha confianza ya que no es necesario conocerse para realizarlo. Iniciaras una conversación sobre el tema que prefieras, el punto es que cuando sea el turno de hablar de la otra persona, tú mostraras todo el desinterés 
3 Tan Importante como Respirar: La Comunicación

del que seas capaz, puedes: cambiar el tema, voltear hacia otros lados, revisar tu celular, interrumpir para dar tu opinión. Realiza esto durante 5 minutos aproximadamente y observa cuál es su reacción. Posteriormente continúas conversando normal y notas su actitud.

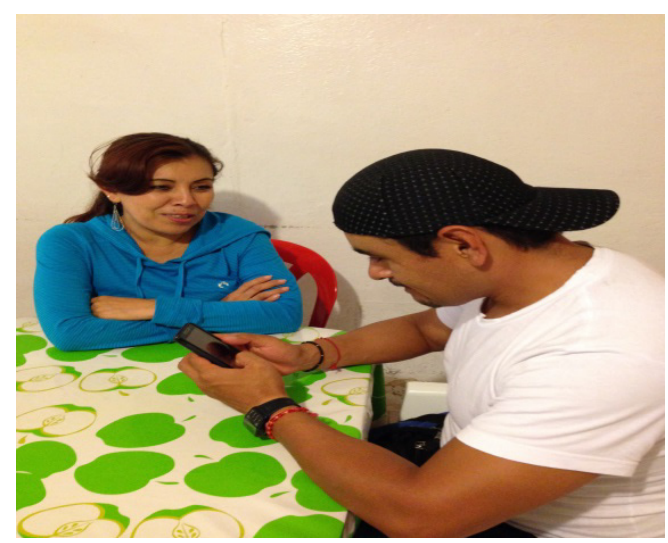

Reflexiona: ¿Cómo te sentiste al realizar este ejercicio? ¿Cuál fue la reacción de la otra persona? ¿Te percataste de sus emociones? ¿Te ha pasado en la vida cotidiana?

La comunicación es algo que realizamos de manera tan cotidiana que muchas veces lo hacemos de forma automática y se nos olvidan ciertos detalles, que son sumamente importantes para tener una adecuada relación con los demás, como lo es el prestar atención y que la otra persona lo perciba; pues es posible que podamos hacer dos cosas al mismo tiempo, sin embargo, la otra persona puede sentir que lo que dice no es realmente importante para nosotros y perder la confianza que nos ha brindado ¿cómo te sentirías tú?

\section{ELEMENTOS BÁSICOS DEL PROCESO DE COMUNICACIÓN}

En cualquier proceso de comunicación hay que considerar la presencia, estrictamente necesaria de seis elementos básicos, que todos conocemos, pero que no siempre tomamos en cuenta: emisor, mensaje, receptor, código, canal y contexto. 


\section{Elementos de la Comunicación}

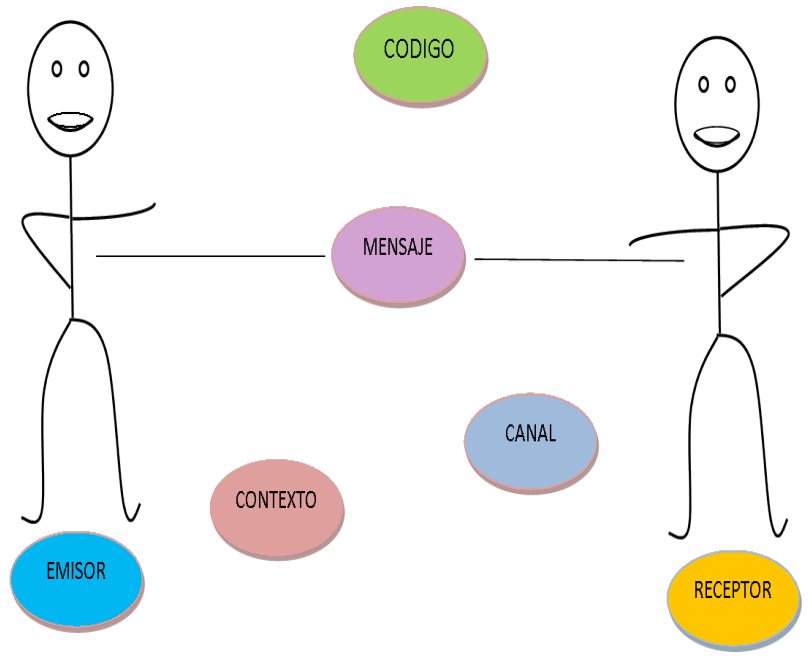

Emisor: es quien abre el proceso de la comunicación mediante la transmisión de un mensaje.

Mensaje: es el conjunto de ideas que el emisor desea transmitir al receptor y constituye el elemento central del proceso de comunicación.

Receptor: es la persona a quien va dirigido el mensaje que envía el emisor. Quien analiza los significados del mensaje y se convierte en un emisor al responder al mensaje que le fue enviado.

Código: es el conjunto de normas, lenguajes y símbolos que sirven para transmitir el mensaje y debe ser conocido tanto por el emisor como por el receptor. Es decir ambos deben conocer el significado de lo que se está transmitiendo, de lo contrario existirán dificultades en la comunicación. Por ejemplo: dos personas que hablan diferentes idiomas. 
3 Tan Importante como Respirar: La Comunicación

Canal: Medio a través del cual se emite el mensaje, puede ser oral, escrito o pictográfico.

Contexto: se refiere al conjunto de circunstancias que rodean al acto de la comunicación. Se puede decir que es el escenario, el lugar, las circunstancias, el tiempo en el que se lleva a cabo la comunicación.

(:) Realiza una actividad: elige una noticia o algún suceso reciente, e intenta comunicárselo a alguna persona cercana, con quien te sientas en confianza, sin utilizar la palabra ni oralmente, ni escrita, puedes hacer gestos, mostrar imágenes, realizar ademanes, lo que se te ocurra.

Reflexiona: ¿Te costó trabajo realizarlo? ¿Cómo te sentiste al no poder hablar? ¿Lograste transmitir adecuadamente el mensaje?

Como te pudiste dar cuenta no siempre es necesario utilizar el lenguaje verbal para que se realice el proceso de comunicación, ya que en todo momento estamos comunicando algo, debido a que existen muchas otras formas de transmitir un mensaje. Quizá el mensaje que recibió tu receptor no era exactamente el que querías transmitir y posiblemente sentiste una gran impotencia de no poder hablar, sin embargo, te puedo asegurar que logró entender algo de lo que intentabas transmitir.

Es por esto que, debemos tomar en cuenta estos elementos básicos del proceso de comunicación y de asegurarnos de utilizar todos los recursos que estén a nuestro alcance para transmitir el mensaje de una manera adecuada. Lo primero que exista una persona que reciba el mensaje que deseamos enviar, después debemos asegurarnos de que domine el mismo código, ya que de esta manera entenderá adecuadamente el mensaje, el cual debe estar claramente estructurado y finalmente que el contexto sea adecuado. Veamos algunos ejemplos: 
Mejora tu calidad de vida y rendimiento académico a través del autoaprendizaje

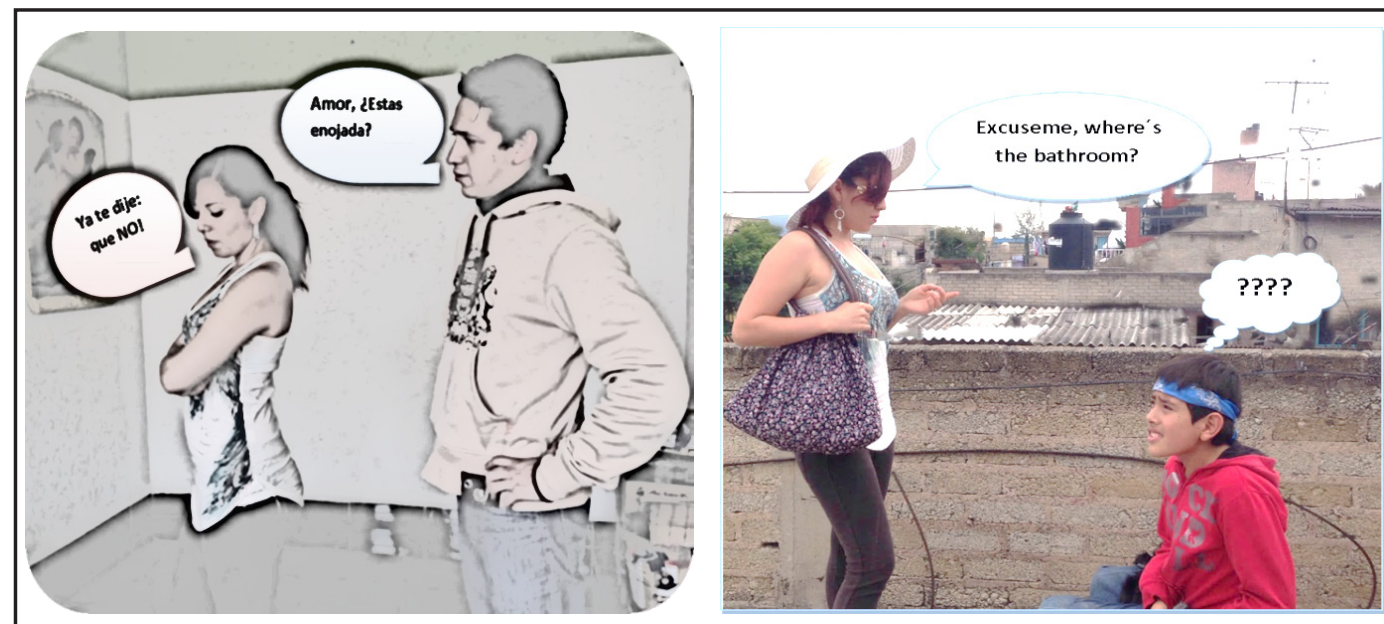

En la primera imagen podemos observar que el mensaje que envía la mujer no es claro, debido a que contesta que no está enojada, pero su actitud muestra lo contrario. Y en el segundo ejemplo, el mensaje no está llegando adecuadamente a la otra persona, debido a que no dominan el mismo código (el idioma).

Cuando no tenemos claro un mensaje, tendemos a distorsionarlo, ya que por lo general, se nos queda en la memoria aquello que nos llama más la atención, o lo que creemos que es más importante y para que tenga coherencia le agregamos algunos elementos más, distorsionando el mensaje original, por eso es importante asegurarnos de que el mensaje que estamos entendiendo, es el mismo que nos pretenden enviar; esto se puede lograr preguntando a la otra persona si hemos entendido bien.

\section{ES IMPOSIBLE NO COMUNICAR}

Una propiedad básica del comportamiento, es que no hay algo que sea lo contrario de comportamiento, es decir, no existe el no comportamiento y, por lo tanto, es imposible no comportarse. Moverse o permanecer quieto, hablar o guardar silencio, sonreír o mostrarse indiferente, presentarse o retirarse de una situación, todos constituyen comportamientos (Watzlawick, Bavelas \& Jackson, 2002). 
3 Tan Importante como Respirar: La Comunicación

;:) Observa las siguientes imágenes y contesta: ¿Qué es lo que está expresando cada una de las personas?
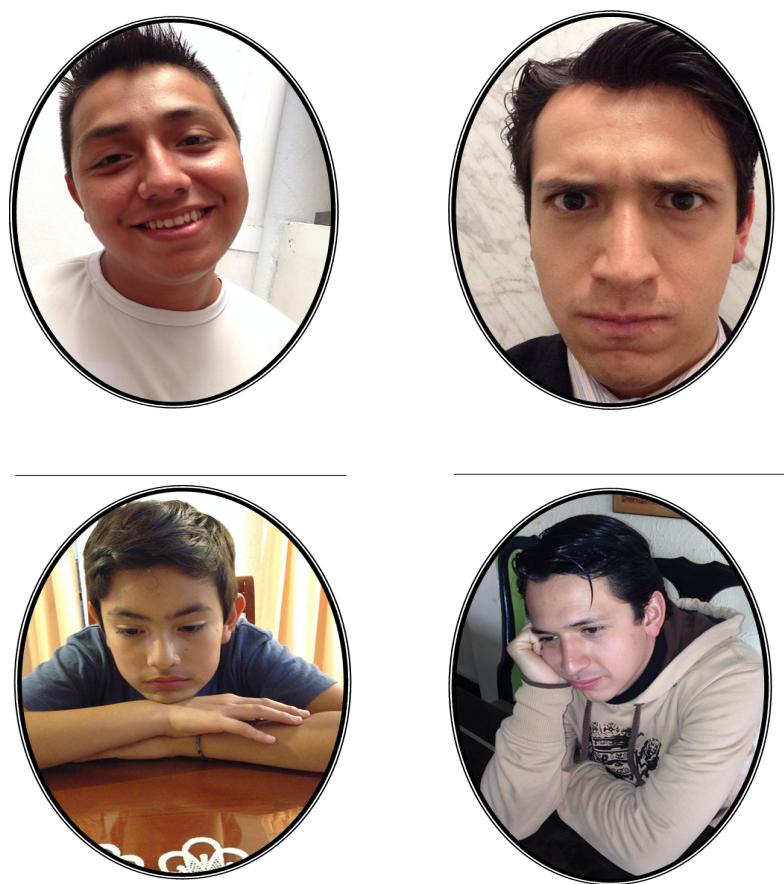

Reflexiona: ¿Te pareció difícil entender lo que expresó cada uno de ellos? ¿Por qué crees que pudiste identificar esas expresiones? ¿Intenta recordar alguna situación en la que hayas visto alguna de esas expresiones? ¿De qué manera reaccionaste?

En nuestra vida cotidiana, quizá sin darnos cuenta vamos interpretando el comportamiento de las demás personas y con base en eso decidimos cuál será nuestro comportamiento, de manera que, si notamos que una persona esta triste, lo más probable es que nos acerquemos a consolarla. No debemos olvidar que todo comportamiento en una situación de interacción tiene un valor comunicativo, por lo que no se puede dejar de comunicar, aun cuando se intente (Hidalgo \& Abarca, 1999). 
Mejora tu calidad de vida y rendimiento académico a través del autoaprendizaje

\section{COMUNICACIÓN VERBAL Y NO VERBAL}

Como lo hemos estado trabajando, la comunicación puede ser verbal y/o no verbal, podemos referirnos a los objetos de dos maneras totalmente distintas: se les puede representar por un símil, como un dibujo, o mediante un nombre (palabra) y ambos son equivalentes (Watzlawick, Bavelas \& Jackson, 2002), te puedo decir es un limón y salivas o bien te lo presento o su imagen, de igual forma salivas.

- La comunicación verbal (o digital): se centra en el habla, el lenguaje. Los objetos o eventos son expresados mediante un conjunto de signos arbitrarios que no guardan necesariamente una semejanza estructural con dicho objeto o evento. Por ejemplo, no existe nada particularmente similar a una mesa en la palabra "mesa" (Del Prette, \& Del Prette, 1999).

- La comunicación no verbal (o análoga): Se encuentra presente en todas las relaciones cara a cara, exista o no intercambio verbal. Se refiere a todo lo que no se expresa verbalmente como la postura (proxémia), gestos y expresión facial (kinesia) y la regulación de la voz (paralingüística).

(:) El siguiente ejercicio te ayudará a comprenderlo mejor: con alguna persona de tú alrededor inicia una conversación del tema que prefieran, trata de que no sea un tema muy profundo, y realiza lo siguiente: 1) "LO QUE EL PUEDE HACER YO LO PUEDO HACER MEJOR". Escucha atento todo lo que la otra persona te dice, pero debes retar todo lo que diga. Puedes interrumpir mientras se encuentra hablando, anticipar lo que te dirá a continuación, señalarlo con un dedo, inclinarte hacia delante en señal de agresión y realizar otros actos no verbales que enfaticen tu comportamiento verbal. Después que hayas realizado tus críticas, espera y anima a la otra persona para que continúe la conversación. Tu tarea es no ser parte de la conversación por lo tanto, simplemente interrumpe, manifiesta tu desacuerdo o refuta lo que dice. Realiza esto aproximadamente 15 minutos y después explícale a la persona que se trataba de un ejercicio y discúlpate, le puedes preguntar cómo se sintió y que le ayudo a continuar. Anota en cuaderno, que utilizarás exclusivamente para los ejercicios de esta guía, tus observaciones sobre la reacción de la otra persona. 
3 Tan Importante como Respirar: La Comunicación

2) “¿A QUIÉN LE INTERESA?" Después elige a otra persona y has lo siguiente: Escucha con cuidado lo que te dice, pero también transmítele señales no verbales que indiquen tu total aburrimiento, por ejemplo: mira hacia otro lado, hazte el tonto, húndete en tu silla o estírate, retuércete y juguetea, limpia tus uñas o juega con tu ropa, entre otros. Si la otra persona te culpa de falta de interés, insiste en que si te interesa (hasta le puedes repetir lo que ha dicho), pero sigue enviando señales no verbales de aburrimiento. Realiza esto aproximadamente 15 minutos y después explícale a la persona que se trataba de un ejercicio, discúlpate y agradécele por ayudarte a trabajar estos elementos de la comunicación y pídele sus comentarios. Anota tus observaciones.

3) "ESTOY DE ACUERDO CONTIGO". Ahora inicia una conversación con otra persona: Debes estar atento, escuchar con cuidado y aprobar todo lo que la otra persona diga, sin importar lo que tú pienses al respecto. Cuando tu opinión se oponga a lo que lo que te dice, sólo sonríe mientras indicas tu aprobación. Puedes hacer comentarios como: "Es una buena (gran) manera de decir las cosas", "Es muy interesante lo que dices", "Tienes toda la razón". Resiste a cualquier invitación de la otra persona a dar tu verdadera opinión. Realiza esto aproximadamente 15 minutos y después explícale a la persona que se trataba de un ejercicio. Anota tus observaciones.

4) "ASÍ ES COMO DEBERÍA SER". Por último selecciona a otra persona: Escucha con atención todo lo que te está compartiendo. Indica que entiendes sus ideas repitiéndolas. Si no estás de acuerdo, simplemente hazle saber tus ideas con calma y lógica. Pide una aclaración o ejemplos que pudieran serte útiles para comprender mejor. También puedes indicar que estás interesado en la conversación usando señales no verbales tales como establecer contacto visual e inclinándote hacia el emisor. Debes representar un papel activo en el proceso de hacer la conversación lo más clara y recíproca posible. Realiza esto aproximadamente durante 15 minutos y después explica a la persona que se trataba de un ejercicio y pídele sus comentarios. Anota tus observaciones. 
Mejora tu calidad de vida y rendimiento académico a través del autoaprendizaje

Reflexiona: ¿Cómo te sentiste al realizar cada uno de los papeles? ¿Te identificaste con alguno, o algunos, de ellos? ¿Cuál fue la reacción de cada una de las personas antes de saber las instrucciones? ¿Cuál fue la reacción de las personas después de saber las instrucciones? ¿Con cuál de los cuatro papeles que realizaste te sentiste más cómodo? ¿Con cuál de ellos te sentiste más incómodo? ¿Qué tan frecuente crees que suceda esto en la vida cotidiana? Escribe tus respuestas en tu cuaderno. Y sigue experimentando en tus conversaciones el $4^{\circ}$ estio que es el que te permite tener un mejor nivel de comunicación, más efectivo y eficiente, además es más respetuoso y honesto.

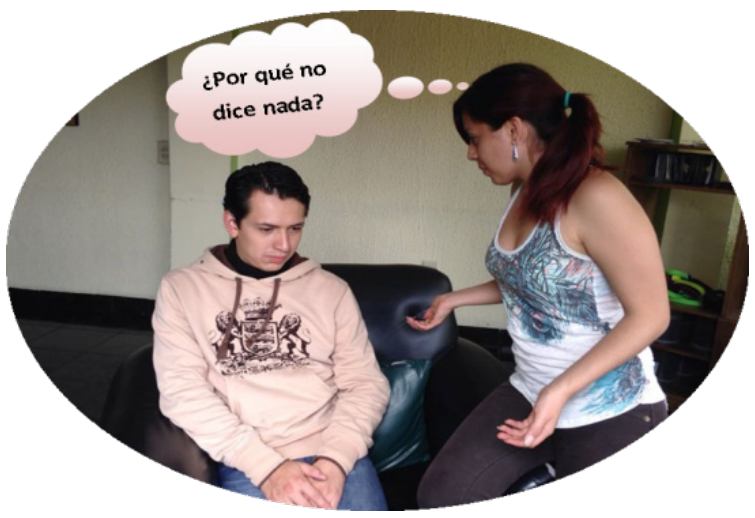

De los cuatro papeles que representaste los dos primeros muestran una contradicción entre el lenguaje verbal y el no verbal, ya que a pesar de que le estabas prestando atención, tu comportamiento indicaba lo contrario. En el primer caso mostrabas tu desinterés al querer hablar sólo de ti y mostrarle que tú eras o podías hacer todo mejor que él o ella; en el segundo caso el comportamiento no verbal también indicaba claramente un total desinterés de tu parte, al distraerte con otras cosas.

Con la tercera persona no existió una contradicción, sin embargo, el no ser parte de la conversación y sólo aprobar lo que el otro dice, entorpece la comunicación, como se mencionó anteriormente, está implica una interacción, si sólo asentimos a todo lo que alguien nos dice, y no damos nuestro punto de vista, es posible que la otra persona piense 
3 Tan Importante como Respirar: La Comunicación

que no es importante para nosotros lo que nos está diciendo o que no le prestamos atención, por eso no tenemos nada que decir.

Con la última persona el lenguaje verbal y el no verbal se encontraban en completa armonía; y es eso lo que se necesita para poder tener una adecuada comunicación con los demás, veamos algunos factores que son importantes considerar al momento de relacionarnos con otras personas:

Latencia del habla: Se refiere al tiempo que tardamos en contestar cuando hablamos con alguien. Una alta frecuencia de respuestas demoradas puede ser bastante perjudicial en una conversación. Del mismo modo responder con rapidez, de inmediato después de que la otra persona ha hablado, en algunos casos puede dificultar las interacciones satisfactorias. La latencia debe adecuarse al contenido del mensaje que nos están transmitiendo y al contexto en que ocurre la interacción.

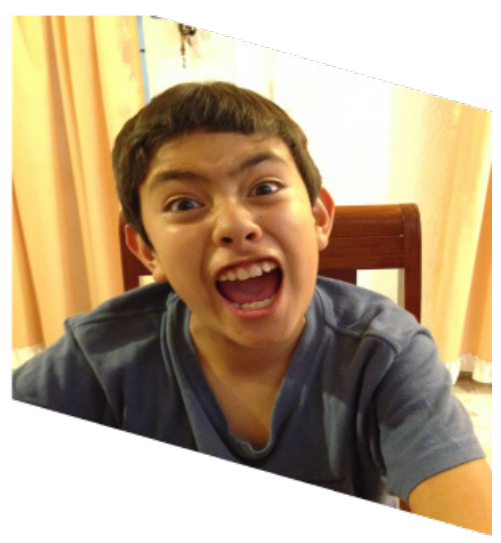

$\checkmark$ Duración del habla: Esto es, el tiempo en que una persona permanece hablando sin conceder al otro, la oportunidad, de uso de la palabra. Tomar la palabra durante mucho tiempo puede causar aburrimiento a quien escucha y dificultar interacciones futuras. 
$\checkmark$ Postura corporal: Sucede en las tres posiciones más comunes: de pie, sentado o agachado y acostado. Es muy fácil de observar, sin embargo, posee ciertos matices que escapan al observador; por ejemplo, cuando dos personas se encuentran en una conversación adoptan la misma postura, por lo general sucede de manera inconsciente e indica que ambos se encuentran en la misma sintonía lo cual es una señal de correspondencia. Algunas posiciones son captadas por el interlocutor, como señal de interés, cortesía, amistad, aborrecimiento o aversión.

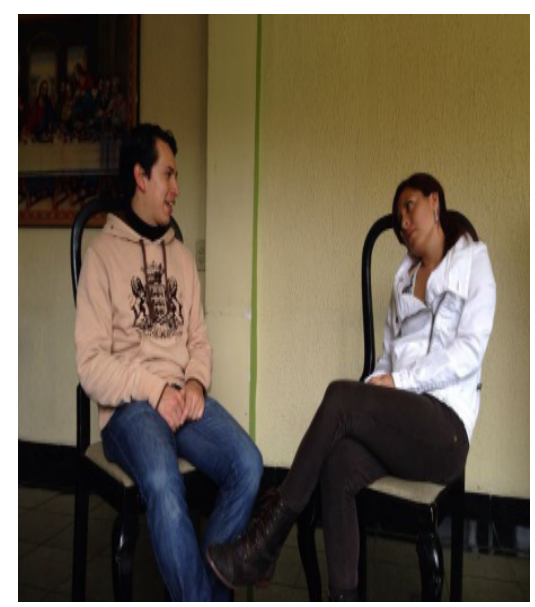

$\checkmark$ Gestos y expresión facial: Traducen, contradicen, confirman o niegan lo que se dice, debido a que los movimientos de la cara son los elementos visuales de mayor impacto para el receptor, ya que le indican cómo interpretar las palabras. El rostro posee una flexibilidad impresionante debido a su compleja red de músculos, capaz de producir una gran cantidad de expresiones. 


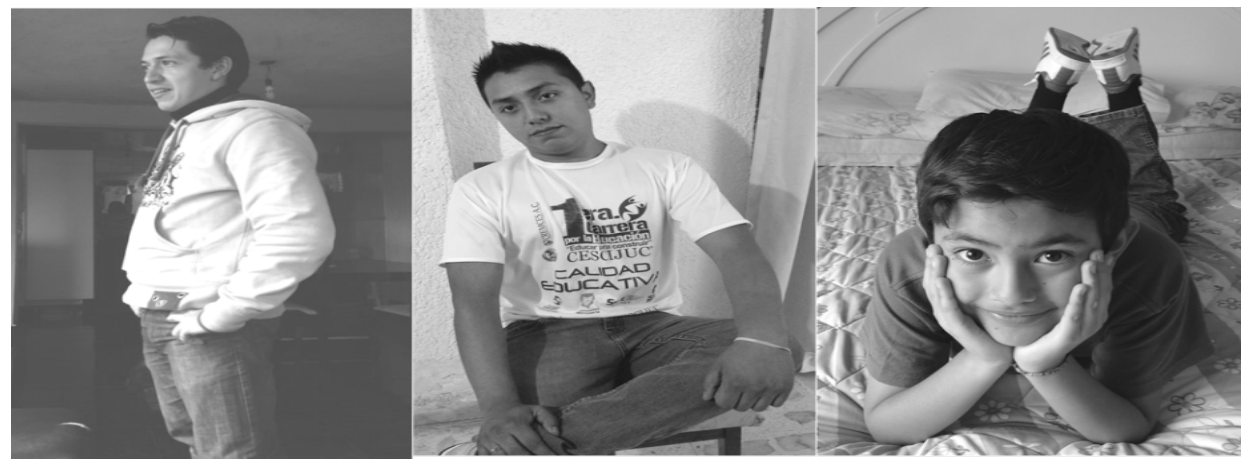

$\checkmark$ Regulación de la voz: Las personas tienden a adecuar su forma de hablar de acuerdo con la persona y el contexto en el que se encuentren, pues hablan en un tono bajo en un teatro y alto en un antro repleto de personas, suelen conversar en un ritmo lento a la salida del trabajo y de manera apresurada cuando se despiden de alguien que está a punto de irse al trabajo; se emplea una entonación diferente en las expresiones "me gustas", "te odio" o cuando se dice "pásame la sal".

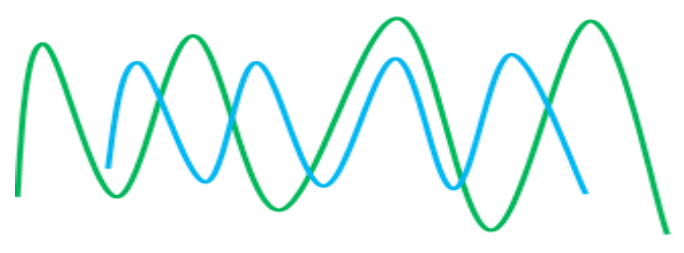

Existen personas que de manera habitual suelen hablar de forma muy rápida o muy lenta, y pueden encontrar dificultad en obtener la atención de los demás; pues pueden ser percibidas de forma diferente según la modulación de voz que utilicen: un volumen demasiado bajo puede sugerir sumisión; uno muy alto enojo o ira y uno demasiado variable, temor y sorpresa. Un mismo discurso puede ser percibido de diferentes maneras, en función de la modulación y volumen de voz del emisor. 
Mejora tu calidad de vida y rendimiento académico a través del autoaprendizaje

\section{NIVELES DE CONTENIDO Y LAS RELACIONES DE LA COMUNICACIÓN}

El proceso de la comunicación, además, obedece a una doble función: la que está orientada a la actividad y la orientada a la relación, también se conocen como los aspectos "referenciales" y "conativos" respectivamente, ya que en la comunicación no sólo se trasmite información, sino que al mismo tiempo se imponen conductas (Watzlawick, Bavelas \& Jackson, 2002).

- El contenido del mensaje o aspecto referencial, únicamente trasmite la información, que puede referirse a cualquier cosa que sea comunicable al margen de que la información sea verdadera o falsa, valida, no valida o indeterminable.

- El aspecto relacional o conativo, hace referencia a qué tipo de mensaje debe entender el receptor y por ende, a la relación que existirá entre los comunicantes.

Es posible que el mensaje tenga el mismo contenido (información), pero que definan relaciones distintas, según la forma en que se digan las cosas. Por ejemplo, cuando Marco le preguntó a Rossy por las llaves del auto, ella le respondió: "las Ilaves están sobre la mesa" (aspecto de contenido o referencial), el hecho de decirle dónde estaban las llaves fue amistoso (aspecto conativo o relacional), así mismo, el tono en que lo expresó, el hecho fue burlón, expresa una crítica es una aspecto connotativo y relacional.

(:) Esta actividad te facilitará la compresión de estos aspectos, habla con alguna persona de tu alrededor y dile algo que pienses sobre él o ella, pero utilizando expresiones corporales, faciales y tono de voz totalmente contrarios a lo que estás diciendo; por ejemplo: decirle a tu pareja, "estoy muy enojado/a contigo" con un tono alegre y expresiones faciales relajadas. Observa cual es la reacción de la otra persona.

Reflexiona: ¿Cómo te sentiste al realizar este ejercicio? ¿Te pareció difícil realizarlo? ¿Te ha pasado algo parecido en la vida cotidiana?

Este ejercicio nos hace ver manera muy clara que la comunicación además de transmitir información, define la relación que tendremos con las demás personas dependiendo de 
3 Tan Importante como Respirar: La Comunicación

"como" decimos las cosas. Pues no es lo mismo decir "dame el libro" a "me das el libro, por favor", si bien, ambas transmiten la misma información, (el hecho de que quiero el libro) la segunda expresión resulta más amigable que la primera y me ayudará a tener una mejor relación con la otra persona. Por lo general la relación, se expresa en forma no verbal, con los gestos, la postura corporal y el tono de voz con que enviamos los mensajes.

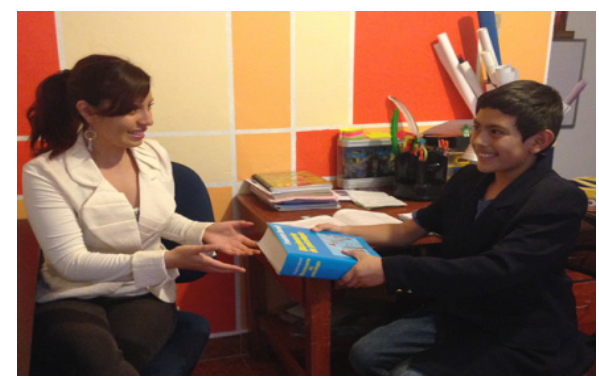

\section{LA PUNTUACIÓN DE LA SECUENCIA DE HECHOS}

Toda conducta que tenemos es un estímulo que produce una reacción y esta reacción es a su vez un estímulo para una próxima reacción y así sucesivamente. Cada conducta es causada por algo, pero a la vez es causa de algo. En este sentido se puede definir a la comunicación como una serie ininterrumpida de intercambios; sin embargo, siempre realizamos una puntuación que organiza los hechos de la conducta (Ceberio, 2006).

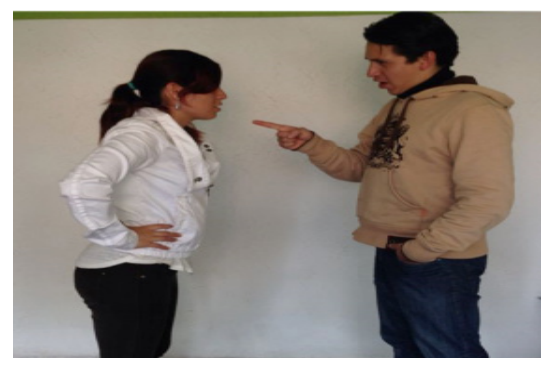

Quienes participan en la interacción necesariamente puntúan la secuencia de hechos arbitrariamente. Por ejemplo: María explica su problema de alcoholismo como una defensa 
Mejora tu calidad de vida y rendimiento académico a través del autoaprendizaje

contra las constantes ausencias de su marido, dado que, lo experimenta como abandono; Felipe, por su parte, dice que se aleja debido al alcoholismo de ella (Watzlawick, Bavelas \& Jackson, 2002).

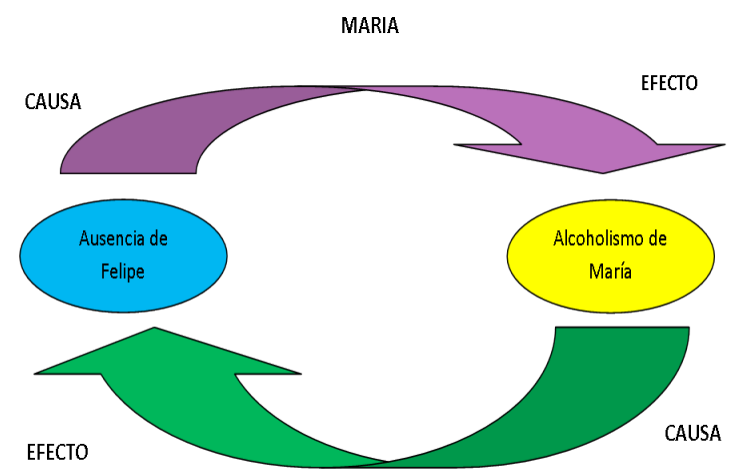

FELIPE

Esta secuencia circular de comportamientos que se retroalimentan es organizada, arbitraria y unilateral por cada participante, de tal manera que los hechos aparecen como causas o efectos según quien los perciba: "tomo alcohol (efecto) porque tú me tienes abandonada (causa)" y "te abandono (efecto) porque te alcoholizas (causa)". La puntuación organiza los hechos de la conducta y resulta vital para las interacciones en marcha. La falta de acuerdo con respecto a la manera de puntuar la secuencia de hechos es la causa de incontables conflictos en las relaciones.

(:) ¿Alguna vez has tenido una discusión interminable con alguien, por no estar de acuerdo en cómo sucedieron las cosas? ¿Qué fue lo que sucedió, según tu percepción? ¿Qué hiciste o hicieron para llegar a un acuerdo? Anótalo en tu cuadernillo que has destinado para las actividades de esta guía.

Reflexiona: ¿Por qué crees que cada quien haya percibido algo diferente? ¿Qué crees que se puede hacer para evitar conflictos, con respecto a la puntuación de la secuencia de hechos? 
3 Tan Importante como Respirar: La Comunicación

Cada ser humano tiene una forma única de percibir los estímulos del medio ambiente y cada uno le da su propia interpretación y realiza juicios sobre lo que sucede; para evitar conflictos, por la puntuación de los hechos, es importante platicar lo sucedido y llegar a un acuerdo, si a pesar de hablarlo, no se logra el acuerdo, lo recomendable es romper con el "circulo vicioso" que se ha formado, por ejemplo, en el caso de María y Felipe, si María dejará de tomar, quizá Felipe estaría más tiempo en casa o si Felipe estuviera más tiempo en casa ella dejaría la bebida; no es necesario que ambos cambien su comportamiento, con que uno de ellos lo haga todo se modificará y mejorará la relación.

\section{INTERACCIÓN SIMÉTRICA Y COMPLEMENTARIA}

Ahora hablaremos sobre el tipo de interacción que establecemos con las demás personas que puede ser simétrica o complementaria.

- Interacción simétrica: Se basa en la igualdad, los participantes intercambian el mismo tipo de comportamiento; tanto uno como el otro puede, indistintamente, tomar decisiones, criticar y comentar la conducta del otro, dar consejos y proponer alternativas.

- Interacción complementaría: Sucede cuando los participantes intercambian diferentes tipos de comportamientos, la conducta de uno complementa la del otro. En una relación de este tipo hay dos posiciones distintas: uno ocupa la posición superior o primaria, mientras que el otro ocupa la posición inferior o secundaria.

(:) Identifica qué tipo de interacción tienes con las personas que te rodean, cada uno los miembros de tu familia, amigos, maestros, jefe y pareja, entre otros. $Y$ escríbelo en tu cuaderno.

Reflexiona: ¿El tipo de interacción que tienes con cada uno de ellos, favorece la relación entre ustedes? ¿Consideras que deberías cambiar algún tipo de interacción para mejorar la relación?

Es importante resaltar que la relación complementaria es más común entre padre e hijo, jefe y subalterno, médico y paciente, entre otros, donde uno de los dos posee un nivel 
Mejora tu calidad de vida y rendimiento académico a través del autoaprendizaje

jerárquico más alto que el otro, uno da órdenes y el otro obedece, lo cual no sucede en la relación simétrica que es más frecuente entre compañeros de curso, de trabajo, amigos o hermanos, porque aquí todos se encuentran al mismo nivel y ambos pueden tomar decisiones por igual e incluso criticar el comportamiento que tiene el otro.

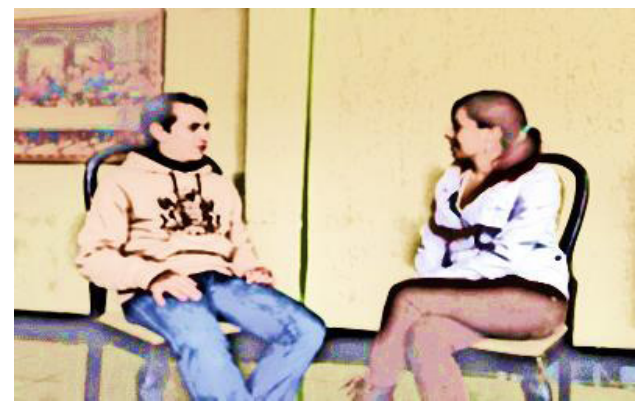

Sin embargo, esto no significa que todo el tiempo tengamos una tipo de interacción con cada persona, pues dependiendo la situación nos podemos portar de manera simétrica o complementaria con una misma persona, por ejemplo, la relación que existe entre madre e hijo, se supone es complementaria, ya que ella es una figura de autoridad para el niño, sin embargo, en algún momento el niño puede revelarse y exponer sus puntos de vista y hacerle críticas a ella, como si fuera uno de sus hermanos o amigos y la interacción que están teniendo en ese momento se convierte en simétrica.

En una situación de conflicto (una discusión), donde la relación simétrica entre dos personas no llega a ningún lado, sólo a empeorar las cosas, lo recomendable es tomar una postura completaría, para evitar que el conflicto sea más grande y desgastante para ambas partes. Veámoslo, en la discusión que tiene una pareja, debido a que Tania afirma que Fredy no es lo suficientemente cariñoso con ella, mientras que él sostiene que si lo es, sólo que ella no lo sabe apreciar; aquí comienza una discusión sin fin, donde ambos tendrán suficientes argumentos para sostener su punto de vista, como lo vimos anteriormente. Por lo que, para evitar que el conflicto crezca, alguno de los dos tendrá que cambiar su comportamiento, es decir, alguien tiene que ceder. O negociar, ahora cedo y la próxima te toca a ti. 
3 Tan Importante como Respirar: La Comunicación

\section{8. ¿QUÉ ES LA ESCUCHA ACTIVA?}

De acuerdo con Van-Der Hofstadt, (2005) la escucha activa consiste en poner todos los medios que estén a nuestro alcance, para lograr entender lo que nos quieren decir, mostrando además un afán de interés ante la presencia del mensaje y una conducta de colaboración con el emisor en su tarea de comunicar.

Escuchar de manera activa implica mucho más que el simple proceso físico de oír; es importante fijar nuestra atención en el mensaje que vamos a recibir, de modo que se nos facilite la comprensión de este, además, es conveniente analizar el mensaje, sin distorsiónalo con interpretaciones subjetivas asociadas a prejuicios que podamos tener acerca del tema (Dugger, 2006). Practicar la escucha activa nos ofrece muchas ventajas:

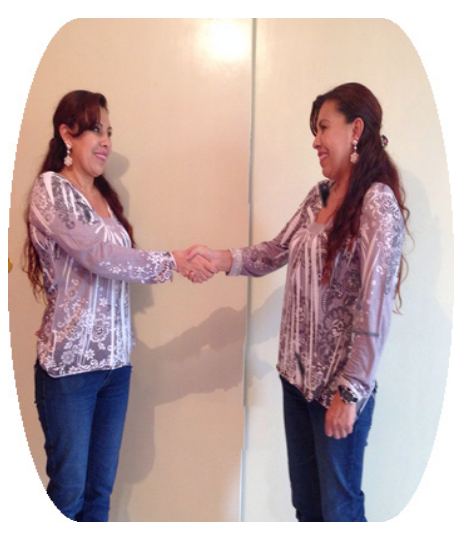

- Mayor conocimiento del emisor. El escuchar durante cierto tiempo los argumentos de la otra persona, permitirá aproximarnos con mayor exactitud a sus estrategias. Además la observación de sus expresiones no verbales, nos servirán como indicadores para comprender con más claridad sus intenciones y objetivos.

- Mejora la predisposición del emisor. El emisor percibe un mayor interés por parte del receptor acerca de sus ideas, opiniones y puntos de vista con lo que se consigue su cooperación y se facilita el proceso de la comunicación. 
Mejora tu calidad de vida y rendimiento académico a través del autoaprendizaje

- Disminuye la ansiedad del emisor. Al permitirle que se exprese con libertad durante un cierto tiempo, se reduce su tensión al comunicar y esto le brinda mayor confianza. Pues de acuerdo con Dugger, (2006) "El arte de la escucha es, en gran medida, el arte de la espera".

- Más tiempo para responder. Practicar la escucha activa permite al receptor disponer de más tiempo para pensar posibles respuestas, organizar argumentos y valorar las mejores opciones.

- Más seguridad en las decisiones. Se tiene mayor seguridad sobre el mensaje que se le está transmitiendo por un lado, y por otro ayuda a detectar con mayor facilidad las posibles inconsistencias en los argumentos del otro.

- Facilita alcanzar acuerdos. Al evitar las interrupciones al emisor, le brindamos una mayor seguridad sobre la expresión de sus ideas y podemos comprender mejor su punto de vista.

Para lograr escuchar activamente, es necesario poner atención a la otra persona, intentando entender su punto de vista y sus sentimientos. Es importante mostrar interés, para ello podemos asentir con la cabeza, mantener la mirada o realizar expresiones como "y que paso después"; también se debe clarificar, es decir, pedir más información, para que el mensaje resulte más claro. Se trata de ampliar la información para tener una visión más clara de la situación. Del mismo modo, Parafrasear, resulta muy útil para verificar si hemos entendido bien el mensaje, esto es, repetir con palabras similares las principales ideas o pensamientos que ha expresado la persona a la que escuchamos; se expresa la situación tal como la hemos entendido según la percepción de la otra persona.

(:) Puedes poner en práctica tu escucha activa, pidiendo a alguien que te cuente su historia de vida, o bien pide que te cuenten sobre un momento muy importante en subida, procura que no sea una persona que conozcas de mucho tiempo. Posteriormente escribe en tu cuadernillo, la historia que te contaron.

Reflexiona: ¿Te fue difícil concentrar todos tus sentidos en lo que te decía la otra persona? ¿Cómo te sentiste al escuchar activamente? ¿Te costó trabajo escribir lo que te contaron? ¿De qué manera crees que beneficie a la comunicación? 
3 Tan Importante como Respirar: La Comunicación

\section{IMPORTANCIA DE LA ASERTIVIDAD Y LA AUTOESTIMA EN LA COMUNICACIÓN}

\section{ASERTIVIDAD}

La asertividad es un elemento fundamental para lograr una comunicación adecuada. Wolpe (1958 citado en Hidalgo \& Abarca, 1999) la define como: "la capacidad social de expresar lo que se piensa, lo que se siente y las creencias, en forma adecuada al medio, en ausencia de ansiedad".

Por su parte, Riso (1988 citado en Hidalgo \& Abarca, 1999) la define como: "aquella conducta que permite a la persona expresar adecuadamente, combinando los componentes verbales y no verbales de la manera más efectiva posible: oposición (decir que no, expresar desacuerdos, hacer y recibir críticas, defender derechos y expresar en general sentimientos negativos) y afecto (dar y recibir elogios, expresar sentimientos positivos en general) de acuerdo con sus intereses y objetivos respetando el derecho de los otros e intentando alcanzar la meta propuesta".

Con base en lo anterior, podemos decir que la asertividad es la conducta que nos permite expresar de forma adecuada, combinando los componentes verbales y no verbales de la manera más efectiva posible, lo que pensamos, sentimos y creemos, sin sentirnos mal por ello.

(:) Te voy a pedir que escribas en tu cuaderno lo siguiente: YO TENGO DERECHO: en mi casa a..., en mi trabajo o escuela a..., en mi grupo de amistades a... Tal como se muestra a continuación, y vas a escribir los derechos que consideras tener en cada uno de ellos.

Una vez que hayas terminado, escribe en otro hoja: LOS OTROS TIENEN DERECHO A RECIBIR DE Mí: en mi casa..., en mi trabajo o escuela..., en mi grupo de amistades..., y de igual manera deberás escribir lo que consideres que los otros tienen derecho a recibir de tu parte.

Reflexiona: ¿Te resultó difícil identificar tus derechos? ¿Qué área se te dificultó más? ¿Y con respecto a los derechos de los demás, te fue difícil identificarlos? ¿Por qué consideras 
Mejora tu calidad de vida y rendimiento académico a través del autoaprendizaje

que son importantes estos derechos? ¿Existió alguna diferencia entre tus derechos y los de los demás? Si es así ponte en su lugar y revísalos nuevamente.

Aprender a reconocer los derechos básicos de las otras personas sin descuidar los propios y saber que cada derecho que tenemos lo tendrán también las otras personas, es de suma importancia para lograr una comunicación eficaz. Pues si tratamos a los demás como nos gustaría que nos trataran a nosotros, probablemente tendremos relaciones más satisfactorias. Así mismo debes saber que tus derechos terminan en donde inician los de los demás. Como tú tienes derecho a solicitar que te den o presten algo, pero sabiendo que el otro tienen derecho a decidir si lo hace o no, sin ninguna obligación, así mismo, cuando te solicitan algo, en ningún momento estás comprometido a aceptar, debes decidir, "si quiero y puedo hacerlo" lo haces y si no se dan juntos estos elementos, si no deseas o puedes, la respuesta asertiva es: no.

Existen tres tipos de conducta asertiva: el comportamiento asertivo de alabanza, el comportamiento asertivo de rechazo; y el comportamiento asertivo de petición.

Comportamiento asertivo de alabanza: Se refiere a la expresión de sentimientos positivos tales como la alabanza, el YO TENGO DERECHO.

- Aprecio y el agrado; los cuales, pueden facilitar las relaciones interpersonales positivas. La habilidad para alabar a otro de una manera cálida, sincera y amistosa, puede ser una destreza interpersonal extremadamente poderosa y hacer que un individuo sea un compañero agradable para interactuar (Hidalgo \& Abarca, 1999). Así como alabarte y reconocer las cosas buenas que haces en muy importante, en realidad es reconocer lo que haces bien.

- Comportamiento asertivo de rechazo: Se da cuando tienes el deseo de rechazar una petición o demanda que alguien te hace, o cuando otra persona está tratando de bloquear o interferir el logro de una meta. es sustancial aprender a discriminar situaciones en las que es apropiada la asertividad de rechazo (como, no firmar un 
3 Tan Importante como Respirar: La Comunicación

cheque en blanco), de otras en que el rechazo puede ser inadecuado por el contexto (rehusarte a hacer un trabajante diferente o tarea no propia de la actividad, como darle dinero o hacer un trabajo de un tema totalmente que te pide tu maestro o jefe).

- Debes ser capaz de discriminar la conducta asertiva de la agresiva.

La conducta asertiva en comparación con la conducta agresiva, es percibida positivamente en su relación con el otro, logra las metas que se propone y favorece la relación interpersonal a largo plazo; con la filosofía es bueno para mí y es bueno para ti, es decir todos ganamos, que es muy saludable. Mientras que la conducta agresiva puede alcanzar sus fines durante algún tiempo, pero la mayor parte de las veces lleva a una comunicación defectuosa, provoca la agresión defensiva y tiende a estimular la propia agresividad; tiene la filosofía de yo gano, es bueno sólo para mí, por lo tanto es egoísta y nada saludable para los demás.

Por otro lado, puede ser que no se tenga una conducta agresiva, pero sí una conducta de sumisión que se encuentra en el otro extremo, pues las personas no valoran sus derechos y creen que decir que "no" es algo inadecuado, porque desde la infancia nos han enseñado que debemos complacer a nuestros padres y a otros adultos; tiene una filosofía de los otros ganan, y yo pierdo, por ello, nada saludable para mí, por lo que no participaré más con esa filosofía. Bishop, (2000) asegura que frecuentemente los niños prefieren complacer y ser sumisos ante los demás, ya que el buen comportamiento siempre es recompensado con premios y sonrisas.

- Comportamiento asertivo de petición: Ocurre cuando se hace una petición a otro con el objeto de satisfacer una necesidad o el logro de una meta. Este comportamiento por lo general ocurre en conjunto con el comportamiento asertivo de rechazo, en situaciones en que el otro rechaza una petición no racional y le solicita al otro un cambio en su comportamiento ("No, no te daré dinero; por favor no vuelvas a pedirme"). La petición sirve para evitar que el conflicto vuelva a repetirse en el futuro.

(:) De acuerdo con lo anterior, escribe en tu cuaderno, tres situaciones en las que hayas tenido un comportamiento asertivo de alabanza con alguien y tres en las que tuviste un comportamiento asertivo de rechazo, acompañado del comportamiento asertivo de petición. 
Mejora tu calidad de vida y rendimiento académico a través del autoaprendizaje

Reflexión: ¿De qué manera crees que influya el comportarse de manera asertiva, en la comunicación con las demás personas? ¿Será diferente la reacción de los otros, según él comportamiento que utilicemos? ¿Porque? Escribe las respuestas en tu cuadernillo.

La asertividad significa una comunicación lograda y esto no quiere decir solamente saber encontrar las palabras adecuadas en una situación determinada. El tono de la voz, el volumen, la expresión facial, los gestos y el lenguaje corporal forman parte del mensaje que estamos enviando a otras personas (Bishop, 2000).

Es importante resaltar que la asertividad es un comportamiento que se aprende, no una cualidad con la que nacen las personas, por lo que no podemos decir que una persona es agresiva o asertiva, sino, que tiene un comportamiento agresivo o asertivo, según sea el caso y por lo tanto, dicho comportamiento se puede modificar. Además, de que nadie es puramente agresivo, ni sumiso, ni siquiera asertivo. Las personas tenemos tendencias hacia alguna de estas conductas, pero no nos comportamos siempre así, ni lo hacemos en todas las situaciones o relaciones.

\section{Autoestima}

La autoestima es otro factor importante para lograr una comunicación adecuada, Montoya (2001) la define como la capacidad o actitud interna con la que me relaciono conmigo mismo y que hace que me perciba dentro del mundo, de una forma positiva. Esto se refiere a cómo me veo a mí mismo y la opinión que tengo sobre mi persona. Se compone de dos aspectos fundamentales:

- La eficacia personal: que se refiere a la confianza en el funcionamiento de mi mente, en mi capacidad para pensar y entender, para aprender, elegir y tomar decisiones; confianza en mi capacidad para entender los hechos de la realidad que entran en el ámbito de mis intereses y necesidades.

- El respeto a mí mismo: que significa el reafirmarme en mi valía personal; en una actitud positiva hacia mí derecho de vivir y de ser feliz; el confort al reafirmar de forma 
3 Tan Importante como Respirar: La Comunicación

apropiada mis pensamientos, mis deseos y mis necesidades; mi sentimiento de que la alegría y la satisfacción son mis derechos innatos naturales (Branden, 2003).

(:) Te sugiero una actividad, siéntate tranquilo y relájate, reflexiona en todas las cosas buenas que haces en cada día, en que te has respetado y sentido pleno. Bien, escribe en tu cuaderno por lo menos 10 veces, la frase YO SOY... y a continuación anota las características sobre tu persona que consideres que son positivas, pueden ser cualidades, logros, destrezas, conocimientos o capacidades.

Reflexiona: ¿Cómo te sentiste al realizar la actividad? ¿Te costó trabajo escribir características positivas sobre ti? ¿Lograste escribir las 10 características?

A la mayoría de las personas se nos dificulta reconocer las cualidades positivas que poseemos; esto ocurre porque casi siempre nos comparamos con modelos que están fuera de nuestra realidad y que provocan una disminución en la estima que nos tenemos. Para ilustrar esto, supongamos que una adolescente, compara su belleza con la estrella de cine Megan Fox, probablemente va a sentir que no es lo suficientemente bonita, sin embargo, debes entender que cualquier comparación que realices debe ser interna, es decir, contigo mismo, con alguien externo no es válido, porque siempre hallarás a alguien mejor o peor que tú, y no sirve de nada para tu desarrollo y bienestar, que es el tema que te ocupa. Si dices el mes pasado pesaba 50 kilos y ahora peso 80, es claro que estás muy pasado de kilos, y que debes bajarlos por tu propia salud, no por lo que te digan los demás.

Es importante mencionar que las personas quienes nos rodean han jugado un papel primordial en la opinión que tenemos de nosotros mismos, pues los humanos nacemos muy dependientes para sobrevivir y los primeros 7 u 8 años de nuestra vida vamos de totalmente dependientes (al nacer) a ser más independientes, al menos en autocuidado, obviamente no para ser autónomo (independiente financieramente), en dónde los adultos cercanos nos dicen todo lo que debemos hacer y nos realimentan de lo que hacemos bien y frecuentemente dicen "si haces algo bien, eres buen niño", así si alguien nos dice que 
Mejora tu calidad de vida y rendimiento académico a través del autoaprendizaje

somos inteligentes y capaces de lograr muchas cosas, lo creeremos y nos sentiremos con la confianza de intentar cosas nuevas, por el contrario, si nos dicen que somos "tontos" llegara un momento en que lo creeremos y así nos consideraremos. Es muy importante que sepas que tú por ti mismo eres valioso, eso no tiene discusión, lo que si se cuestiona es tu comportamiento, la forma en que actúas, que puedes cambiar con trabajo y decisión. Por medio de la comunicación, nos enseñan una serie de pensamientos y actitudes, que favorecerán o perjudicaran, de cierta manera, el desarrollo de habilidades que tendremos (Beauregard, Bouffard, \& Duclos, 2005).

(:) Ahora cierra tus ojos y piensa en esos mensajes que tú recuerdas, de lo que los adultos y personas significativas te decían: marcando en que "eres bueno o no serías", anótalas y a su lado escribe que has hecho al respecto has cumplido esas profecías o las has derrotado, en las que cumpliste reflexiona de qué manera las puedes derrocar y en que "eres bueno o sería bueno" ¿cuáles de ellas has cumplido y cuáles no has realizado?, y anota de qué manera puedes lograr las que no has cumplido. Y reflexiona cuáles son tus sentimientos y emociones al hacer estas reflexiones, considera que las personas te decían lo que ellos creían, generalmente sin malicia, era lo que se creía en la época. Así que no las culpes, pero ahora creo que has comprendido que ya eres tú el responsable de lo que logres en tu vida y que con esta y las demás guías tienes herramientas para lograrlo.

Las personas que presentan un baja autoestima construyen una imagen de sí mismos desvalorizada, manifestándose en lo que generalmente se denomina como inseguridad, no quererse a sí mismo o no valorarse. Según Hidalgo \& Abarca (1999) las experiencias de fracaso en el logro de objetivos constituyen una importante fuente de información para determinar la autoestima de una persona.

(:) Ahora te propongo, que en otra hoja escribas las tres o cuatro cosas que más te molesten de ti mismo, tus más grandes fallas o debilidades; es decir lo que no te gusta de ti mismo, pero que admites como cierto. Y que ahora establezcas un plan de actividades $y$ compromisos para cambiar esas situaciones. 
3 Tan Importante como Respirar: La Comunicación

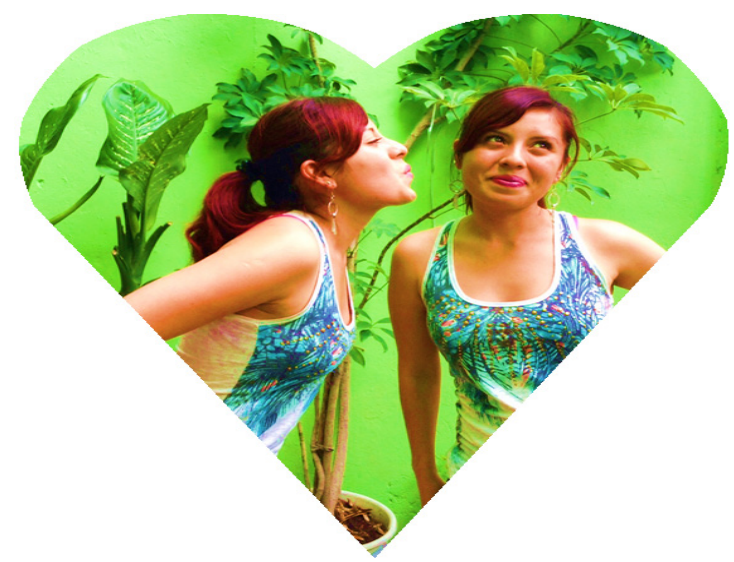

Reflexiona: ¿Cómo te sentiste al realizar este ejercicio? ¿Te costó trabajo encontrar tus debilidades? ¿Crees posible convertir esas debilidades en fortalezas? ¿Te comprometes contigo mismo?

Es importante reconocer que todos, absolutamente todos tenemos debilidades, fallas y limitaciones; sí además, nos comparamos con alguien y peor si es muy lejano a nuestra realidad, posiblemente tendremos una autoestima baja, frustración y desilusión. Ahora bien, sireconocemos que todos los seres humanos somos imperfectos yaceptamos nuestras debilidades, esforzándonos por mejorar en esos aspectos, y nos comprometemos con nosotros mismos, nos esforzamos y practicamos nuevas cosas, nuevos comportamientos y nuevas y mejores formas de comunicación asertiva seguramente nuestra autoestima mejoraría notablemente.

(:) Te invito a reflexionar sobre tus debilidades y a que te enfoques en convertirlas en fortalezas. Recuerda que nadie puede ser bueno en todo, pero si podemos hacer todo lo que esté en nuestras manos para mejorar lo que no hacemos tan bien.

Es de suma importancia, que te comprometas activamente para modificar tus patrones de conducta y mejorar tu comunicación, ya que de este modo lograrás ser más efectivo 
Mejora tu calidad de vida y rendimiento académico a través del autoaprendizaje

en tus interacciones sociales; al pedirte que te comprometas, me refiero a llevarlo a la práctica. Pues nadie mejora sus habilidades de comunicación con sólo leer un manual, es sustancial que lo experimentes en tu vida diaria. Es posible que no logres dominar todo de un día para otro, pero puedes comenzar poco a poco en situaciones donde el éxito o fracaso no te afecte y así paulatinamente lo podrás ir extendiendo a todas las áreas de tu vida. Recuerda: "Ia práctica hace al maestro".

Muy bien, has terminado de trabajar con esta guía, ahora realiza la evaluación final para que veas cuanto has mejorado. Realizándola de la misma manera que al inicio y compara tus resultados. Espero hayas salido mejor, si no fue tan alto como esperabas no te desanimes, como ya te dije esto hay que practicarlo y te invito a revisar aquellos ejercicios en que hayas sentido que no saliste muy bien y continúa con otras guías, todas están preparadas para continuar el recorrido de lograr el fortalecimiento de tus habilidades y llevarte al bienestar.

Gracias por tu compromiso y te deseo éxito en tu proceso de crecimiento. 


\title{
Elementos para establecer relaciones interpersonales positivas
}

\author{
Sandra Galindo Méndez
}

V

ivimos en un mundo contemporáneo, donde te encuentras expuesto a múltiples factores de riesgo psicosocial, de los cuales con mucha frecuencia no estás muy consciente. Por ello, se han diseñado programas: para promover conductas positivas específicas, desarrollando las aptitudes o habilidades para la vida (Castro Sariñama y Llanes, 2007) que te ayuden a estar preparado para hacerles frente y superarlos.

El tema de Habilidades Psicosociales es un modelo cuyo objetivo es contribuir en forma efectiva a favorecer al desarrollo saludable de los adolescentes. Este enfoque ayuda a desarrollar habilidades y destrezas socio-cognitivas y emocionales para permitirte que adquieras las aptitudes necesarias para el desarrollo humano y para enfrentar en forma efectiva los retos de la vida diaria (Mangrulkar, Whitman y Posner, 2001).

En todas tus relaciones interpersonales -ya sean familiares, de pareja, de amistad, laborales, sociales y políticas- debes aprender a convivir en armonía y evitar riesgos en tu vida (Conde, 2010). El hecho es que dadas las características e importancia de estas relaciones, la manera en como la lleves va a ser fundamental para el logro de tus objetivos y acuerdos que resulten beneficiosos para las partes involucradas, o por el contrario, te lleven a sentir que la relación se ha convertido en una carga o en un permanente malestar, lejos de confortarte, te agobia y genera conflictos en tu vida. Es por ello que, cree la presente guía a fin de ayudarte a que desarrolles las habilidades psicosociales para que tengas un adecuado manejo de las relaciones interpersonales en aras de hacerlas funcionales agradables y beneficiosas, incluyo los siguientes temas: 
Mejora tu calidad de vida y rendimiento académico a través del autoaprendizaje

- Establezco buenas Relaciones humanas: las relaciones que una persona establece con los demás de manera armoniosa, respetuosa, provechosa y colaborativa, en donde ambas partes reciben beneficios. Así, dar y recibir es un requisito para las buenas relaciones humanas.

- entrando en Contacto con mi Autoconocimiento: es el descubrimiento de ti mismo para una mejora personal, mediante respuestas a las preguntas ¿Quién soy yo? Y ¿Para qué ser? (Herrán, 2003).

- Fortaleciendo Mi Autoestima: es el conocimiento, la aceptación, y el aprecio de tus características personales, y se relaciona estrechamente con la posibilidad de desarrollar tus propias potencialidades (Rogers, 1966).

- Responsabilizándome de Mi Asertividad: es la expresión de tus pensamientos, sentimientos y conductas, defendiendo tus derechos y los de los otros, sin agredir ni ser agredido (Psicología-online, revisado 2013).

- Clarificando Mis Valores: son formaciones motivacionales de la personalidad que te orientan en tu actuación hacia la satisfacción de tus necesidades (González, 1985).

- Optimizando Mi Comunicación. Dado que la buena comunicación es una herramienta fundamental tanto en la vida diaria, como todos los ámbitos en los que nos desarrollamos, tanto a nivel formal, como informal, por ello es de suma utilidad poseer los medios para aumentar su eficacia (Molinaro, $\mathrm{s} / \mathrm{f}$ ).

- Estableciendo Mis Límites: dado que son los indicadores de hasta dónde llegan los derechos y las responsabilidades de las personas que te permiten aprender a vivir en armonía con las personas y así evitar riesgos. Además de aprender a adaptarte a las restricciones de la vida (Conde, 2010).

Los temas citados, resaltan la importancia de contar con programas efectivos que te ayuden a desarrollar estas habilidades por medio de métodos de enseñanza interactivos tales como la presente guía.

Para que experimentes estos temas, te recomiendo que anotes tus notas y respuestas en una libreta, reservada sólo para este trabajo, para que vayas viendo tu nivel de avance. Te menciono que encontrarás este símbolo " para señalarte que tienes que realizar 
4 Elementos para Establecer Relaciones Interpersonales Positivas

una actividad específica. Y encontrarás puntos suspensivos "..." para señalarte que debes realizar una pausa adecuada a la actividad que debes realizar, en cada momento puede ser de diferente tamaño, tú deberás calcular el tiempo que requieres, para cada situación.

\section{Elementos PARA Establecer Relaciones INTERPERSONALES Positivas}

\section{Escala para Evaluar}

Primero que nada te invito a que contestes este cuestionario antes de que inicies este proceso de trabajo, responde de la manera más honesta posible, ya que sólo así podrás aprovechar al máximo las herramientas que se te brindará en esta guía.

INSTRUCCIONES: a continuación te presento algunas afirmaciones, léelas con atención y contesta lo primero que se te venga a la mente, procurando responder todos ellos con la mayor veracidad posible.

\begin{tabular}{|r|l|l|l|l|l|}
\hline No. & \multicolumn{1}{|c|}{ Afirmaciones } & Nunca & $\begin{array}{c}\text { Rara } \\
\text { vez }\end{array}$ & $\begin{array}{c}\text { Casi } \\
\text { siempre }\end{array}$ & Siempre \\
\hline 1 & $\begin{array}{l}\text { A la hora de realizar una petición expreso mis } \\
\text { deseos y necesidades de forma clara }\end{array}$ & & & & \\
\hline 2 & $\begin{array}{l}\text { A parte de los compromisos asisto a los servicios } \\
\text { religiosos }\end{array}$ & & & & \\
\hline 3 & Busco personas que me valoren por lo que hago & & & & \\
\hline 4 & Busco personas que me valoren por lo que soy & & & & \\
\hline 5 & Considero que llevo una vida feliz & & & & \\
\hline 6 & $\begin{array}{l}\text { Creo que los avances científicos benefician a la } \\
\text { humanidad }\end{array}$ & & & & \\
\hline 7 & $\begin{array}{l}\text { Cuando dice "no" ante una petición la hace de } \\
\text { modo directo, sin rodeos }\end{array}$ & & & & \\
\hline 8 & Cuando estoy triste, sé la razón & & & & \\
\hline
\end{tabular}




\begin{tabular}{|r|l|r|l|l|l|}
\hline No. & \multicolumn{1}{|c|}{ Afirmaciones } & Nunca & $\begin{array}{c}\text { Rara } \\
\text { vez }\end{array}$ & $\begin{array}{c}\text { Casi } \\
\text { siempre }\end{array}$ & Siempre \\
\hline 9 & $\begin{array}{l}\text { Cuando hablo, lo hago oportunamente y me } \\
\text { expreso de forma correcta }\end{array}$ & & & & \\
\hline 10 & Cuando tengo un problema acudo a algún amigo & & & & \\
\hline 11 & $\begin{array}{l}\text { Dentro de los integrantes de la familia hay } \\
\text { confianza }\end{array}$ & & & & \\
\hline 12 & El respeto es necesario para entablar una amistad & & & & \\
\hline 13 & $\begin{array}{l}\text { Empleo la modulación y el volumen de voz para } \\
\text { reforzar lo que dijo }\end{array}$ & & & & \\
\hline 14 & En mi familia se dirigen con respeto & & & & \\
\hline 15 & $\begin{array}{l}\text { En mi familia se expresan con cariño hacia los } \\
\text { integrantes }\end{array}$ & & & & \\
\hline 16 & Estoy satisfecho con mi condición física & & & & \\
\hline 17 & Estoy seguro (a) de las decisiones que tomo & & & & \\
\hline 18 & Estoy seguro (a) de lo que quiero en la vida & & & & \\
\hline 19 & Expreso a mi pareja algún cariño & & & & \\
\hline 20 & Expreso claramente opiniones y deseos & & & & \\
\hline 21 & $\begin{array}{l}\text { Expreso lo que quiero decir directamente siendo } \\
\text { respetuoso con el otro }\end{array}$ & & & & \\
\hline 22 & Expreso lo que siento con gestos & & & & \\
\hline 23 & Expreso lo que siento con palabras & & & & \\
\hline 24 & Expreso lo que siento por las personas & & & & \\
\hline 25 & La amistad es tan necesaria para la vida social & & & & \\
\hline 26 & La confianza es fundamental entre amigos & & & & \\
\hline 28 & La honestidad es primordial en la amistad & & & & \\
\hline 29 & La honestidad es primordial en mi familia & & & & \\
\hline
\end{tabular}


4 Elementos para Establecer Relaciones Interpersonales Positivas

\begin{tabular}{|c|l|l|l|l|l|}
\hline No. & \multicolumn{1}{|c|}{ Afirmaciones } & Nunca & $\begin{array}{c}\text { Rara } \\
\text { vez }\end{array}$ & $\begin{array}{c}\text { Casi } \\
\text { siempre }\end{array}$ & Siempre \\
\hline 30 & $\begin{array}{l}\text { La honestidad es primordial en mi relación de } \\
\text { pareja }\end{array}$ & & & & \\
\hline 31 & $\begin{array}{l}\text { Los hombres tienen más derechos a un puesto de } \\
\text { trabajo que una mujer }\end{array}$ & & & & \\
\hline 32 & Me considero muy inteligente & & & & \\
\hline 33 & Me dirijo con respeto hacia mi pareja & & & & \\
\hline 34 & $\begin{array}{l}\text { Me encuentro animado al habla. Mi lenguaje } \\
\text { corporal es rico }\end{array}$ & & & & \\
\hline 35 & Me enojo con facilidad & & & & \\
\hline 35 & Me esfuerzo para lograr lo que me propongo & & & & \\
\hline 37 & Me expreso con cariño hacia mis amigos & & & & \\
\hline 38 & Me gusta ser como yo soy & & & & \\
\hline 39 & Me molesta mi aspecto, el cómo me veo & & & & \\
\hline 40 & $\begin{array}{l}\text { Me resulta fácil expresar opiniones poco } \\
\text { favorables de los amigos, por temor a herir sus } \\
\text { sentimientos }\end{array}$ & & & & \\
\hline 41 & $\begin{array}{l}\text { Me resulta fácil resistir la inasistencia de mis } \\
\text { amigos cuando me piden hacer algo que no } \\
\text { quiero }\end{array}$ & & & & \\
\hline 42 & Me siento bien conmigo mismo & & & \\
\hline 43 & Me siento exitoso, eficaz & & & \\
\hline 44 & Mi pareja confía en mí & & & \\
\hline 45 & Mi pareja se dirige hacia a mí con respeto & & & \\
\hline 46 & Mi status económico depende de los muebles & & & \\
\hline confianza & & & & \\
\hline
\end{tabular}




\begin{tabular}{|c|c|c|c|c|c|}
\hline No. & Afirmaciones & Nunca & $\begin{array}{l}\text { Rara } \\
\text { vez }\end{array}$ & $\begin{array}{l}\text { Casi } \\
\text { siempre }\end{array}$ & Siempre \\
\hline 48 & $\begin{array}{l}\text { Sé cuál es la mejor forma de expresar mi } \\
\text { decisión, cuando he cambiado de opinión }\end{array}$ & & & & \\
\hline 49 & $\begin{array}{l}\text { Presto atención a la persona con la que estoy } \\
\text { conversando }\end{array}$ & & & & \\
\hline 50 & Reconozco y acepto mis defectos & & & & \\
\hline 51 & Reconozco y acepto mis habilidades & & & & \\
\hline 52 & $\begin{array}{l}\text { Sé cómo abordad a una persona extraña que } \\
\text { empieza a acercarse y me incomoda }\end{array}$ & & & & \\
\hline 53 & $\begin{array}{l}\text { Sé cómo abordar a mi pareja cuando su } \\
\text { acercamiento me incomoda. }\end{array}$ & & & & \\
\hline 54 & $\begin{array}{l}\text { Sé cómo acercarme a una persona del sexo } \\
\text { opuesto cuando me gusta }\end{array}$ & & & & \\
\hline 55 & Sé manejar mis emociones en situaciones difíciles & & & & \\
\hline 56 & Sé me facilita expresar mis sentimientos & & & & \\
\hline 57 & Sé relacionarme con personas conocidas & & & & \\
\hline 58 & Sé relacionarme con personas extrañas & & & & \\
\hline 59 & Siento que a nadie le importo & & & & \\
\hline 60 & $\begin{array}{l}\text { Sin importar las virtudes o defectos que puedan } \\
\text { tener mis padres los respeto }\end{array}$ & & & & \\
\hline 61 & $\begin{array}{l}\text { Sin importar virtudes o defectos que podamos } \\
\text { tener, siempre debemos amarnos }\end{array}$ & & & & \\
\hline 62 & $\begin{array}{l}\text { Sin importar virtudes o defectos siempre respeto } \\
\text { a mi pareja }\end{array}$ & & & & \\
\hline 63 & $\begin{array}{l}\text { Sin importar virtudes y defectos siempre } \\
\text { debemos amar a nuestra pareja }\end{array}$ & & & & \\
\hline 64 & $\begin{array}{l}\text { Sin importar virtudes y defectos siempre } \\
\text { debemos amar a nuestros padres }\end{array}$ & & & & \\
\hline 65 & Solemos resolver los problemas en familia & & & & \\
\hline
\end{tabular}




\begin{tabular}{|c|c|c|c|c|c|}
\hline No. & Afirmaciones & Nunca & $\begin{array}{l}\text { Rara } \\
\text { vez }\end{array}$ & $\begin{array}{l}\text { Casi } \\
\text { siempre }\end{array}$ & Siempre \\
\hline 66 & Soy capaz de aceptar mis errores & & & & \\
\hline 67 & Soy capaz de reconocer lo que otros hicieron bien & & & & \\
\hline 68 & $\begin{array}{l}\text { Soy capaz de valorar positivamente mis } \\
\text { experiencias personales }\end{array}$ & & & & \\
\hline 69 & Soy una persona entusiasta & & & & \\
\hline 70 & Tengo confianza con mis amigos & & & & \\
\hline 71 & $\begin{array}{l}\text { Tengo facilidad de decir de manera firme y } \\
\text { directa cuando la conducta de los demás me } \\
\text { afecta }\end{array}$ & & & & \\
\hline 72 & $\begin{array}{l}\text { Tengo facilidad para afrontar agresiones físicas } \\
\text { hacia mi persona provenientes de un conocido }\end{array}$ & & & & \\
\hline 73 & $\begin{array}{l}\text { Tengo facilidad para negarme si mi pareja insiste } \\
\text { en tener relaciones sexuales }\end{array}$ & & & & \\
\hline 74 & $\begin{array}{l}\text { Tengo facilidad para pedir disculpas a amigos } \\
\text { cuando mi comentario ha sido desagradable y } \\
\text { fuera de lugar }\end{array}$ & & & & \\
\hline 75 & $\begin{array}{l}\text { Tengo facilidad para pedir explicaciones a mi } \\
\text { pareja }\end{array}$ & & & & \\
\hline 76 & $\begin{array}{l}\text { Tengo facilidad para poder expresar mis } \\
\text { convicciones políticos cundo son distintos }\end{array}$ & & & & \\
\hline 77 & $\begin{array}{l}\text { Tengo facilidad para poder expresar mis } \\
\text { opiniones religiosas cuando son distintos }\end{array}$ & & & & \\
\hline 78 & $\begin{array}{l}\text { Tengo facilidad para reclamar por mis derechos } \\
\text { cuando se me causa injustamente }\end{array}$ & & & & \\
\hline 79 & $\begin{array}{l}\text { Tengo facilidad para reclamar si alguien me toca } \\
\text { sin mi consentimiento }\end{array}$ & & & & \\
\hline 80 & $\begin{array}{l}\text { Tengo facilidad para responder a comentarios } \\
\text { desagradables y hostiles provenientes de } \\
\text { familiares }\end{array}$ & & & & \\
\hline
\end{tabular}




\begin{tabular}{|r|l|l|l|l|l|}
\hline No. & \multicolumn{1}{|c|}{ Afirmaciones } & Nunca & $\begin{array}{c}\text { Rara } \\
\text { vez }\end{array}$ & $\begin{array}{c}\text { Casi } \\
\text { siempre }\end{array}$ & Siempre \\
\hline 81 & $\begin{array}{l}\text { Tengo libertad de control y elecciones sobre la } \\
\text { forma en que desarrollo mi vida }\end{array}$ & & & & \\
\hline 82 & Tengo plena confianza en mi pareja & & & & \\
\hline 83 & Yo soy responsable de lo que ocurre en mi vida & & & & \\
\hline
\end{tabular}

Califica tus respuestas de acuerdo con la clave que se presenta a continuación. Asignando los puntos de la siguiente manera:

\begin{tabular}{|l|l|l|l|}
\hline Nunca $=1$ punto & Rara vez $=2$ puntos & Casi siempre $=3$ puntos & Siempre $=4$ puntos
\end{tabular}

Casi todos los reactivos, se califican de esta forma a excepción de los reactivos: 3, 35, 39 y 59 , en los que debes calificar de manera contraria.

\begin{tabular}{|l|l|l|l|}
\hline Nunca $=4$ punto & Rara vez $=3$ puntos & Casi siempre $=2$ & Siempre $=1$ puntos \\
\hline
\end{tabular}

Al terminar suma los puntajes obtenidos y busca en la siguiente tabla la interpretación:

\begin{tabular}{|c|l|}
\hline Puntuación & \multicolumn{1}{|c|}{ Nivel de Desarrollo de Habilidades Psicosociales en mis Relaciones } \\
\hline $\mathbf{0 - 1 1 0}$ & $\begin{array}{l}\text { Bien venido, Te encuentras en la Zona de Desarrollo. Debes de poner empeño } \\
\text { en tus relaciones y modificar o desarrollar nuevas Habilidades Psicosociales. } \\
\text { Es un buen reto, continúa adelante con esta guía y con las demás del texto } \\
\text { para que estés excelentemente preparado en esta área y sobretodo diviértete, } \\
\text { verás que cada actividad que realices sentirás que esto vale la pena. }\end{array}$ \\
\hline $\mathbf{1 1 1 - 2 2 2}$ & $\begin{array}{l}\text { Bien. Estas en un punto bien, sin embargo no está de más esforzarte un } \\
\text { poquito, para que tengas mejores resultados. Este es un proceso dinámico, } \\
\text { y siempre debes esforzarte por superarte estar mejor en esta área que } \\
\text { repercute en todas las áreas de tu vida. }\end{array}$ \\
\hline
\end{tabular}


4 Elementos para Establecer Relaciones Interpersonales Positivas

\begin{tabular}{|c|l|}
\hline Puntuación & \multicolumn{1}{|c|}{ Nivel de Desarrollo de Habilidades Psicosociales en mis Relaciones } \\
\hline $223-332$ & $\begin{array}{l}\text { Muy Bien. Felicidades. Posees Habilidades para relacionarte mejor. Sin } \\
\text { embargo, es algo dinámico que puede variar por las experiencias, es } \\
\text { conveniente que continúes trabajando, ya que siempre encontrarás algo que } \\
\text { superar y además te vas a divertir con estás actividades de la guía y de las } \\
\text { otras. }\end{array}$ \\
\hline
\end{tabular}

Una vez que realizaste el cuestionario y sabes en qué nivel te encuentras. Ahora te preguntaras ¿qué sigue?, ¿Qué habilidades necesitas desarrollar para relacionarme exitosamente? Y ¿Cómo lo puedo lograr? Para iniciar sigue leyendo y mucho más, jugando, practicando.

Primeramente es necesario saber que es una relación interpersonal y así, averiguar que habilidades debes desarrollar para lograr relacionarte exitosamente. Comenzamos.

\section{Establezco Buenas Relaciones Humanas}

\section{Relaciones Interpersonales}

Te imaginas una vida aislado de los demás, vivir como ermitaño. ¿No verdad? En todo momento estas rodeado de personas con las que, quieras o no, debes interactuar; con tus padres, hermanos, amigos, pareja, maestros, compañeros de escuela o trabajo, incluso debes interactuar (aunque sea brevemente) con otros, tales como el chofer del transporte público, la cajera del supermercado o del banco, el dentista, la vendedora de la tienda o de la farmacia. En pocas palabras, no te puedes escapar de la convivencia con otras personas, pero que bueno, porque las otras personas pueden desempeñar un papel importante en

Por ello, debes tener metas en el aspecto de las relaciones interpersonales, pues tener buenas relaciones humanas es un factor indispensable para el éxito en tu vida. Lo que significa, que para lograr relaciones exitosas debes cumplir con la regla de oro "tratar a los demás como deseas ser tratado". 
Mejora tu calidad de vida y rendimiento académico a través del autoaprendizaje

Sabes, ¿que son las relaciones interpersonales?... (Estos puntos significan que tomes un poco de tiempo para pensar y escribir en tu cuaderno tus ideas).

Todas las personas establecemos numerosas relaciones a lo largo de nuestra vida, como las que se dan con nuestros padres, hermanos, familiares, vecinos, amigos, compañeros, maestros, jefes o hijos. A través de estas relaciones, intercambiamos formas de sentir y de ver la vida; también compartimos la satisfacción de necesidades, intereses y afectos. A estas relaciones se les conoce como relaciones interpersonales.

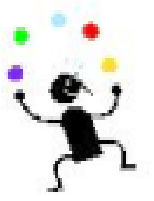

Estas relaciones se rigen por normas y hábitos que te convierten en una persona útil y agradable a tus semejantes, representando todo acto de comprensión y servicio, en un motivo de satisfacción cada vez que lo practicas" (Portel, 1995). Las buenas relaciones humanas benefician a todos sus integrantes, y a las personas con quienes se relacionan externamente a llevarlo sus familiares, compañeros de trabajo, amigos y a la sociedad en general.

Lo que resulta increíble es que día a día te puedes relacionar con tantas personas, considerando que como dice el refrán, "cada cabeza es un mundo", con sus propias experiencias, sentimientos, valores, conocimientos y formas de vida.

Precisamente, en esa diferencia, reside la gran riqueza de las relaciones humanas, ya que al ponerte en contacto intercambias y construyes nuevas experiencias y conocimientos; pero en esa diferencia está también la dificultad para relacionarte, pues tienes que hacer un esfuerzo para lograr comprenderlos y llegar a acuerdos.

Responde de manera más amplia posible, las siguientes preguntas para que analices tu situación actual en tus relaciones interpersonales y puedas saber cómo estás y puedas corroborar tu grado de avance al final.

1. ¿Cómo es mi vida actual en relación conmigo mismo o comunicación interna?

2. ¿Cómo es mi vida actual en relación con mi familia? 
3. ¿Cómo es mi vida actual en relación con mi pareja?

4. ¿Cómo es mi vida actual en relación con la sociedad?

5. ¿Qué interrelaciones guardan entre sí las cuatro áreas anteriores?

Al finalizar, analiza una revisión de cada área en la que te comunicas y puedes desarrollar más aquella en la que habías omitido algunos aspectos.

Reflexiona sobre ¿cuál fue la que se te dificultó más? Tal vez en la que se te dificulto es por que necesitas desarrollar habilidades psicosociales para cambiar tu forma de relacionarte y así estas relaciones sean de tu agrado. Ten en cuenta, que la mayor parte de las personas con las que te relacionas, o al menos compartes con ellas (os) algunas ideas, necesidades e intereses comunes; por lo que, tus relaciones interpersonales deben ser una búsqueda permanente de convivencia positiva.

Pero, ¿cómo lograr que esta convivencia sea de tu agrado? un elemento fundamental en las relaciones interpersonales es que concientices la importancia de la convivencia con los demás e identifiques los sentimientos que provoca el aislarse de un grupo.

\section{Te invito a que te adentres en esta historia. NO SOMOS ISLAS:}

Todos estamos unidos por el amor, por el pensamiento y por la vida. A veces, es sólo un amor, un pensamiento y una vida que ofrecemos a los demás, sin recompensa alguna. Únicamente el egoísta puede decir que está solo. Solo... como Pietro, porque ha renunciado a amar y a ofrecerse a los otros. Solo... porque ha hecho de su vida una isla. Visualiza y dibuja una isla, tal como te veas en soledad.

Ahora subraya la frase que más te impacte y anótala en tu cuaderno de trabajo así como las razones.

Reflexiona: sobre el sentido de estas razones: ¿Cuál fue su origen...? ¿Qué te dieron...? ¿Qué te quitaron o limitaron...? 
Mejora tu calidad de vida y rendimiento académico a través del autoaprendizaje

Ahora que eres consciente de las cosas positivas y negativas que has tenido en cada área de tu vida, es momento de que reescribas los guiones de tus relaciones a fin de que puedas lograr lo que te propones, que entiendo es: "tener relaciones más efectivas y positivas".

Siguiendo con la dinámica, ahora, anota sobre el personaje que realizaste, que eres tú, todo aquello que puede provocar que una persona se aísle de un grupo. Se tratar de tus problemas internos. Y en la isla anota todo aquello que te aísla de las personas, por lo que ellas hacen.

Cuando termines reflexiona sobre estos elementos que te aíslan, de manera muy especial en los que se originan en ti, que representan tus problemas internos que debes resolver. Y si no los solucionas, frecuentemente estarán ahí afectándote. En esta guía o en las otras vas a encontrar algunas actividades para ayudarte en ese sentido. Y luego los elementos que tienen un origen externo.

Reflexiona: A pesar de que te relacionas a diario, en variedad de circunstancias y situaciones; poco o rara vez te detienes a meditar ¿Por qué se te dificulta lograr relacionarte satisfactoriamente? Y ¿Qué necesitas para vencer esta dificultad? En ocasiones, tus diferentes formas de pensar y actuar te pueden llevar a relacionarte con desconfianza o a vivir conflictos, pero valorar a los demás, aceptar que hay diferencias entre una y otra persona y tratar de comprenderlos, puede ayudarte a superar estos obstáculos.

\section{Elementos para Mejorar las Relaciones humanas en Diversas Situaciones}

Un elemento importante en nuestras relaciones lo constituye el pensamiento, Fritzen (1989) menciona el siguiente pensamiento, donde expresa de manera sintética 6 oraciones importantes que debes considerar y manejar en tus relaciones de una manera más adecuada.

Las 6 palabras más importantes:

ADMITO QUE EL ERROR FUE MÍO 
Las 5 palabras más importantes:

HAS HECHO UN BUEN TRABAJO

Las cuatro palabras más importantes:

¿CUÁL ES TU OPINIÓN?

Las tres palabras más importantes:

HAZME ESTE FAVOR

Las dos palabras más importantes:

MUCHAS GRACIAS

La palabra más importante:

NOSOTROS

Piensa en la frase de seis palabras frase y evoca un recuerdo en el cuál hayas considerado que debiste decir esa expresión y de cómo crees que te hubieras sentido en ese momento.

Reflexiona: sobre lo ¿qué opinas con respecto a este pensamiento?... ¿Estás de acuerdo?... ¿Le agregarías alguno más?... Te daré un breve tiempo para que reflexiones...

Frases como estas, en las que actúas de manera atenta, educada y considerada con las personas, te ayuda a mantener buenas relaciones interpersonales. Lo que, favorece tu bienestar tanto individual como social: en lo individual lograrás la satisfacción íntima de motivos emocionales; alcanzarás la superación personal y obtendrás la plenitud como ser humano. En lo social encontrarás que tendrás con mejores capacidades en las relaciones interpersonales poseerás más logros como persona y estimularás eficientemente a quienes te rodean, como: familia, amigos, compañeros, compañeros de diversión, a que sean más creativos y responsables (Padilla, 2004).

Para ello, te recomiendo que revises estos 10 lineamientos para mejorar tus relaciones:

HABLA con las personas. Nada es tan agradable y estimulante como una palabra de saludo cordial, particularmente hoy en día, cuando necesitamos más "gestos amables".

SONRÍE a las personas. Recuerda que para mover la cabeza accionamos 72 músculos y que para sonreír nos basta con movilizar 14 . 
Mejora tu calidad de vida y rendimiento académico a través del autoaprendizaje

LLAMA a las personas por su nombre. Para casi todos, la música más suave es oír su propio nombre.

SÉ AMIGO y servicial. Si quieres tener amigos, sé atento y apoya cuando veas que necesitan tu ayuda.

SÉ CORDIAL. Habla y actúa con toda sinceridad: todo lo que hagas hazlo con gusto.

INTERÉSATE sinceramente por los otros. Recuerda que sabes lo que sabes, pero que no sabes los que otros saben.

SÉ GENEROSO en elogiar y CAUTELOSO en criticar. Los líderes elogian. Saben animar, dar confianza y elevar a los otros. La crítica realízala directamente a la persona con el fin de que se supere.

APRENDE A CAPTAR los sentimientos de los demás. Hay tres ángulos en toda controversia: el tuyo, el del otro y el del que sólo ve lo suyo con demasiada certeza.

PREOCÚPATE de la opinión de los otros. Tres son las actitudes de un auténtico líder: oír, aprender y saber elogiar.

PROCURA APORTAR los buenos servicios que puedes hacer; lo que realmente vale en la vida es lo que hacemos por los demás.

En pocas palabras, tú tienes el derecho de elegir con quien te relacionas, cómo y cuándo. Tienes también el derecho de esforzarte para que tus relaciones con los demás sea lo mejor posible, sin perder tu dignidad.

Por último, tener relaciones interpersonales funcionales y beneficiosas enriquece la calidad de vida, la cual se da, si se tiene un amplio repertorio en habilidades sociales. Por ello la importancia de que desarrolles satisfactoriamente estas habilidades las estás 
4 Elementos para Establecer Relaciones Interpersonales Positivas

trabajando y seguirás en esta guía. Espero que veas que conforme vas avanzando vas viendo cambios en tus relaciones.

Reflexiona: sobre ¿Cuáles son los tres mandamientos más importantes para ti y fundamenta tu selección? ¿Ya las has aplicado y qué resultados has obtenido? ¿Y cuáles son los que te pueden ser más útiles en tus relaciones? y que frecuentemente son los que no estás realizando.

Por ello la tarea es que, encuentres la manera de aplicarlos todos, inicia con los que conoces y has aplicado, como parte del calentamiento, y luego vas por los que te cuestan más trabajo, para finalizar el recorrido. En cada uno que apliques, ve anotando en tu libreta en que situación lo aplicaste y cuáles son los resultados. Y el chiste es que una vez que inicia con uno lo continúas cada vez que puedas hacerlo. En virtud de que entre más prácticas, más lo integras a tu estilo de funcionamiento natural.

\section{LAS HABILIDADES PSICOSOCIALES}

Cuando te relacionas con los demás, esperas reciprocidad, esto quiere decir que deseas dar, pero también recibir; escuchar y ser escuchado, comprender y ser comprendido. Dar y recibir requiere seguridad y claridad de quien eres. Las dificultades están casi siempre relacionadas con la falta de valoración y apreciación que tienes sobre ti mismo o bien, con lo que has aprendido a ver las cosas como "los otros" las ven y a respetar su punto de vista, en virtud de que desde pequeño lo has escuchado, entonces se te hace natural. Los contextos sociales en los que interactúas (familia, trabajo, escuela...) y los agentes sociales con quienes convives (amistades, padres, hermanos, compañeros, entre otros) te han ayudado a interiorizar normas y valores. De aquí, también surgen las demandas y restricciones que debes interpretar en cada caso para responder de manera adecuada.

Para que está continua interacción, sea provechosa, es necesario adquirir y aprender una serie de Habilidades Psicosociales para la vida que procuren y faciliten el encuentro con las demás personas, el intercambio de ideas y pensamientos, sentimientos, emociones y afectos. 
Mejora tu calidad de vida y rendimiento académico a través del autoaprendizaje

Responde la siguiente pregunta ¿Por qué crees que sea necesario tener habilidades Psicosociales para la vida?... Tómate tu tiempo y formula tu respuesta. Cuando termines es importante que consideres que, de acuerdo a la OMS, las habilidades para la vida son aquellas aptitudes necesarias para tener un comportamiento adecuado y positivo que te permitan enfrentarte eficazmente a los retos y desafíos de la vida diaria. Por ello, su importancia radica en son necesarias para que adquieras herramientas psicosociales que te permitan acceder a estilos de vida saludables.

Ahora bien, la pregunta del millón, ¿cuáles son estas habilidades que debes desarrollar para lograr relaciones interpersonales exitosas?

Algunas de las habilidades más importantes y que te sugiero trabajar, que a su vez están consideradas en la guía, son:

$\checkmark$ Autoconocimiento

$\checkmark$ Autoestima

$\checkmark$ Asertividad

$\checkmark$ Comunicación

$\checkmark$ Valores

$\checkmark$ Límites

Empezaré a guiarte cómo desarrollar cada una de estas habilidades psicosociales en el orden anterior, dicho orden lo nombrarás como: "la escalera de las relaciones interpersonales con éxito".

Dibuja la escalera en una hoja y a medida que vayas logrando cada habilidad psicosocial agregarás el color y el nombre de la habilidad en el escalón. 


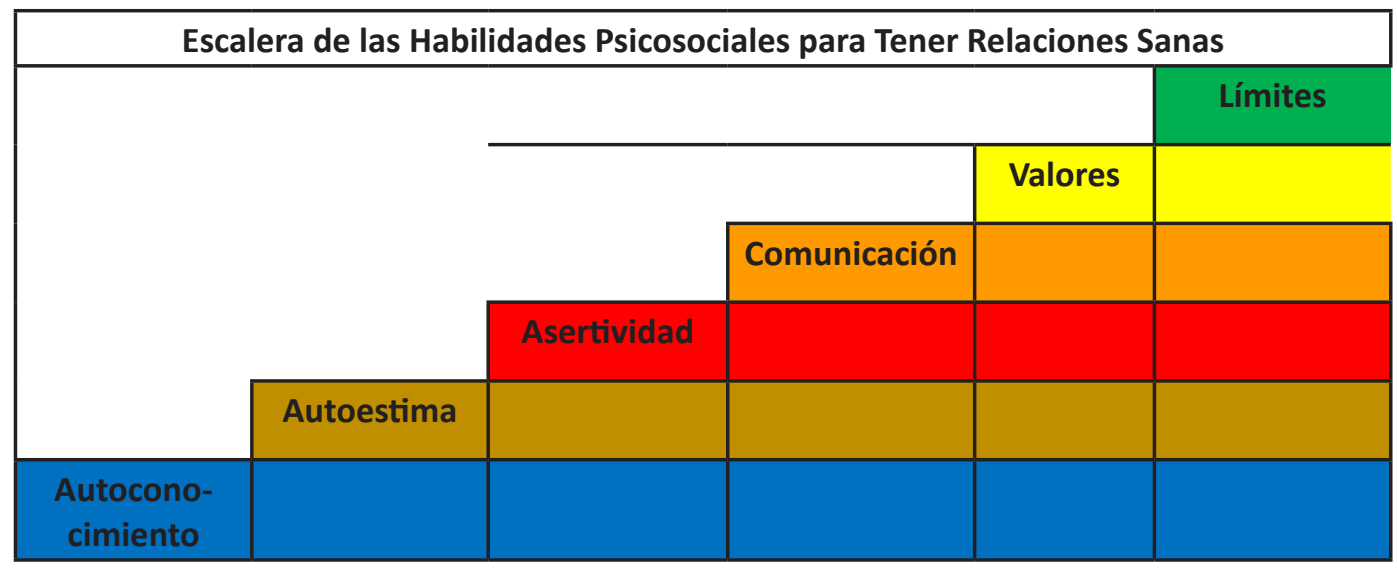

*** Cuando termines de subirla, puedes decir y gritar: iiiSí lo hice, sé que puedo!!! iiiSí pude!!! Y escribe en tu cuaderno cómo te sientes, y qué piensas ahora.

\section{Entrando en Contacto con Mi Autoconocimiento}

\section{1a Habilidad AUTOCONOCIMIENTO ¿Quién soy?}

Si te miras con honestidad, puedes reconocer lo que te disgusta de ti mismo: por ejemplo que es lo que te hace sentir rencor, enojo, envidia e incluso, ser agresivo e irrespetuoso al relacionarte con otras personas.

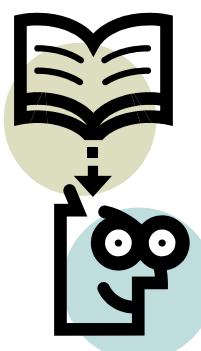

La aceptación y reconocimiento de ti mismo, te pueden ayudar a superar las actitudes negativas y mejorar tus relaciones con otras personas, es decir, la aceptación de los demás con sus cualidades y defectos, y a que surja la confianza en ti mismo y en los demás.

En ocasiones llegarás a pensar que, si te relacionas con gritos y golpes, lograrás que te vean con estimación y autoridad. ¡Gran equivocación! Si te quieres y respetas, no podrás permitir relaciones basadas en la violencia.

Ahora bien, para poder conocerte y desarrollar habilidades psicosociales, deberás seguir ciertos pasos. 
Mejora tu calidad de vida y rendimiento académico a través del autoaprendizaje

En el templo de Apolo, en Delfos está inscrita la frase "conócete a ti mismo". Se le atribuye a Sócrates, cuya importancia radica en su profundidad y significado. Es el principal precepto del ser humano.

"Conócete a ti mismo" se dice fácil, pero que laborioso es llevarlo a la práctica. Conocer tus fortalezas y debilidades es fundamental para lograr relaciones interpersonales exitosas. No puedes construir sobre un terreno cuyas características desconoces. Si construyes sobre un terreno desconocido corres el riesgo de que la construcción se derrumbe.

Lo mismo pasa con tus relaciones. No podes relacionarte exitosamente si tienes defectos o fallas serias que desconoces. Muchas veces deseas poder relacionarte y que estas relaciones sean satisfactorias. Sin embargo suelen fracasar rotundamente y luego te preguntas "¿Por qué?". El oráculo diría: "porque no conocías tus fortalezas y debilidades". Su pongamos que un joven se expresa de manera agresiva ante una situación, emprende una relación de pareja con sus compañeros de clase en donde la asertividad es requisito indispensable. Se lanza a la aventura con un gran entusiasmo, pero al poco tiempo empieza a perder a su pareja (si es que alguna vez las tuvo, porque pareja es alguien similar, del mismo nivel) por su comportamiento agresivo hacia ella.

¿Qué paso? No se dio cuenta de que su comportamiento no era asertivo. Al no reconocer que su agresividad era un defecto y grave, no hizo algo por cambiar, por lo que pensó que su actitud tendría éxito en su relación sin cambiar nada en su vida.

Conocerte a ti mismo es el punto de partida para que tus relaciones interpersonales sean triunfantes. Es por ello que, las preguntas fundamentales que debes hacerte son: ¿Quién soy? ¿Cuáles son mis fortalezas? ¿Cuáles son mis defectos? Responderlas toma tiempo y sólo es de valientes. Pues NO es fácil decir nuestros defectos, pero es necesario reconocerlos, pues lo que no se conoce no puede ser vencido, hay que conocer al enemigo para derrotarlo. Por otro lado también es muy importante que reconozcas tus cualidades y virtudes, en virtud de que en ocasiones estamos más ubicados en los defectos que en las virtudes y no encontramos ninguna o muy escasas. 
4 Elementos para Establecer Relaciones Interpersonales Positivas

Bien es tiempo de iniciar: Cierra tus ojos y para conocerte es importante el autoanalices profunda y honestamente, poniendo atención en todos los eventos que surjan al realizar el análisis y reflexiona en las situaciones en que realizas algo, ¿Cómo reaccionan las personas, y qué te dicen?, si aún con eso no logras identificarlo, pregúntales a las personas más cercanas a ti. Y anótalas en la lista que realices en tu libreta o cuaderno, con el siguiente formato:

\begin{tabular}{|l|l|l|}
\hline \multicolumn{3}{|c|}{ ¿Cómo Soy? } \\
\hline ¿Cómo soy yo físicamente? & ¿Qué cualidades tengo? & ¿Qué defectos tengo? \\
\hline & & \\
\hline
\end{tabular}

Reflexiona: ¿Qué te fue más difícil identificar, rasgos físicos, cualidades o defectos?; conocer tus defectos no debe desanimarte. Alguien, al conocerlos, quizás diga algo como: 'con estos defectos ¿Cómo voy a relacionarme mejor?', No te preocupes, te cambio esa frase por esta: "con estos defectos soy capaz de triunfar en mis relaciones, porque puedo superarlos, porque en vez de desanimarme me impulsan a vencerlos".

Ahora bien, si en el ejercicio anterior identificaste más defectos que cualidades, te invito a realizar esta dinámica y descubrir que tienes habilidades, fortalezas o capacidades más de lo que tú crees.

Dibuja un árbol, en el tronco escribe tu nombre, en cada raíz una habilidad, fortaleza o capacidad que crees poseer y en cada rama un logro, éxito o realización y pon tus debilidades en forma de barrera u obstáculo, una en cada tablilla de la barrera. Cuándo veas el árbol percibe cómo te ves y sientes tú mismo. Piensa si te falta incorporar algo, piensa qué necesitas trabajar para que tu árbol sea más frondoso y de más flores y frutos, anótalo debajo de tu dibujo.

Reflexiona: ¿Te costó trabajo reconocer tus habilidades?, ¿Te fue difícil identificar tus éxitos?, ¿Qué sentimientos te produjo esta experiencia?, ¿Te sientes triste o feliz con tu árbol? 
Mejora tu calidad de vida y rendimiento académico a través del autoaprendizaje

NOTA: En este árbol durante todo el trabajo con la guía le podrás añadir raíces y ramas, al ser más consciente de sobre tus capacidades y logros; CAPACIDADES: respirar, hablar, escuchar, caminar, ver, aprender...; HABILIDADES: leer, explicar en público, cantar...; LOGROS: terminar la carrera, terminar un trabajo, titularse, trabajar...; Y METAS: aprobar el semestre, mejorar mi promedio, mejorar mi vida familiar, individual y social...

Una pregunta que debes hacerte es: "¿A dónde voy si no cambio, si sigo siendo como soy?" para contestarla, debes imaginar un futuro basado en lo que eres ahora, con todos los problemas que estás teniendo. Seguro puedes ver muchos ejemplos a tu alrededor, de personas que se han conformado y que no han trabajado para mejorar, Probablemente no te gustará lo que veas, ojalá, que eso te servirá como motivación para cambiar.

\section{ForTALECIENDO Mí AUtOESTima}

2a Habilidad AUTOESTIMA. La autoestima incluye los siguientes elementos: Quererte, respetarte, aceptarte y valorarte a ti mismo son condiciones absolutamente necesarias para triunfar en la vida. No puedo concebir a una persona exitosa que no se quiera, respete, acepte y valore a sí misma.

Una habilidad básica a desarrollar en niñas, niños y adolescentes es la autoestima; es decir, la capacidad tienes de quererte, valorarte, aceptarte tal como eres y de confiar en ti mismo.

Esta habilidad se construye durante los primeros años de vida, dentro de la familia. Desde que eres pequeño recibes mensajes que te indican si eres aceptado o querido. Después, en la escuela y con los amigos, también conformas la imagen que tienes de ti mismo, a partir de sentimientos y experiencias positivas o negativas que te suceden. Finalmente, a lo largo de tu vida, siempre te valoras en función de lo que quieres lograr y de cómo te perciben las personas más cercanas.

Antes de continuar deseo compartirte algo que dijo Eleanor Roosevelt: "Nadie puede hacerte sentir mal sin tu consentimiento". Ejemplo: llegas irritado por problemas en tu 
escuela, tu mamá te saluda y te pregunta por qué no le hablaste como habían quedado; tú descargas todo tu enojo diciéndole que te hace enojar con sus reclamos. Nadie hace sentir bien o mal al otro, tú eres quien interpreta las cosas de manera incorrecta, debido a tu estado de perturbación emocional, actúas en consecuencia. Dado que no tienes otra salida a tu enojo, lo descargas contra la primera persona que se te pone enfrente. Aquí tu mamá fue agredida sin deberla ni temerla, ella sólo hizo una pregunta, para entender porque no cumpliste con tu promesa. Ella no tenía culpa o responsabilidad de tus problemas. Y pago los platos rotos.

"Tu vales por ser persona, por ser un humano único e irrepetible (ni por clonación puede ser repetido al cien por ciento)" el ser humano es valioso 'per se', lo que es cuestionable es su comportamiento. Vales por lo que eres, no por lo que tienes. La autoestima es una manera de funcionar en la vida, a partir de la cual se evidencia que te asumes como ser valioso, efectivo y merecedor de lo mejor, en todo momento y cualquier situación (Renny y Agosesky, 1999). Es una cualidad que te permite alcanzar tus metas más valiosas. Es una cualidad que te permite dar lo mejor de ti en todo lo que emprendas. Y estás en igualdad de condiciones que los demás seres humanos, que trabajan por lo que desean.

Para tener autoestima debes conocerte, aceptarte y valorarte. Voy a hacerte una pregunta: Si tuvieras un caballo de carreras de 10 millones de pesos, que te hiciera ganar mucho dinero en los hipódromos, ¿Le permitirías desvelarse, drogarse, comer como si fuera a acabarse el forraje de todo el mundo? Seguramente que no. Entonces te haré otra pregunta: ¿No vales tu mucho más que un caballo de carreras? Por supuesto que sí, aunque no estés muy convencido por lo que haya sido tu vida hasta hoy. Pero justamente hoy es el momento de despertar de ese sueño profundo, hoy debes despertar y vivir una nueva vida, una vida llena de retos pero también de esperanza y de logros que todavía ayer no creías poder obtener. Y cuidando tu sueño, tu alimentación, el cigarrillo, las drogas, en fin todo lo que te daña y enferma.

Un buen inicio para desarrollar tu autoestima es aprender a conocerte. Si te conoces y aceptas, aprenderás a valorarte. Lo que tienes que hacer es un verdadero análisis de tus 
Mejora tu calidad de vida y rendimiento académico a través del autoaprendizaje

características y pensar cómo te gustaría ser, revisando tus defectos y cualidades. A partir de eso decidirás si te gusta cómo son o si quieres cambiar algo.

Te propongo este ejercicio para que entres en contacto con tu imagen resaltando lo positivo y el conocimiento de tus atributos, cualidades, capacidades y habilidades.

Ponte frente a un espejo realiza una respiración profunda suave y lenta, en ese momento suave y lenta mente vas a escanearte, es decir, harás un recorrido de tu cuerpo, empezando por la cabeza y terminando en la punta de tus pies... Identifica dos cualidades o características físicas de ti mismo que te agraden...; observa y encuentra dos atributos o aspectos que caracterizan a tu persona que te gustan... perfecto, ahora toca el turno de que establezcas contacto con dos de tus capacidades, habilidades o talentos que te apasionan... muy bien, experiméntate a ti mismo con todos tus sentidos, como poseedor de esas riquezas y siente el bienestar que te presenta y gózalo, ahora realiza una respiración profunda y suave quedándote con esa sensación de bienestar.

Reflexiona: ¿Cómo te fue? ¿Cómo te sentiste? ¿Qué se te dificultó más? Y ¿Qué se te facilitó más? Tener autoestima significa que te caes bien; que te sientes bien aun cuando cometas errores. Los cuales manejaras adecuadamente, restituyendo el bien que quitaste a quién dañaste, ofreciendo disculpas y la promesa de ser cuidadoso a fin de evitar que vuelva a ocurrir. Significa también que puedes hacer muchas cosas bien. iValora lo que eres, enorgullécete de tus logros y haz las cosas cada vez mejor! Esto te ayudará a sentirte mejor y mejorar tu autoestima.

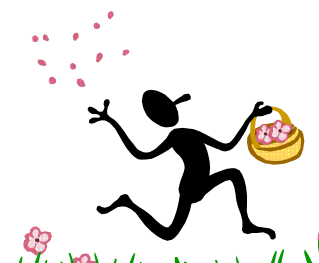

Si tu autoestima es sana estará alta, actuarás de manera decidida, enfrentando los problemas y siendo responsable de las decisiones que tomes. La mayor parte del tiempo estarás a gusto contigo mismo; aceptarás que no todo lo puedes hacer bien y que no le vas a caer bien a todo el mundo; disfrutarás lo que haces y te sentirás seguro y querido. 
4 Elementos para Establecer Relaciones Interpersonales Positivas

Por el contrario, las personas que tienen una baja autoestima dudan de su valor y se sienten poco capaces de realizar cosas; dependen de la aprobación de los demás. Es en estos casos pueden exponerse a situaciones riesgosas, debido a que otras personas se pueden aprovechar de la influencia que tienen sobre ellos, al ceder a la presión de otros diciendo que sí a todo para ser aceptados o caer bien.

De ahí, la importancia de fortalecer tu autoestima, de que te aceptes y te respetes a ti mismo para que puedas enfrentar obstáculos y lograr salir adelante. Sin embargo, si fuese tu caso, que tuvieras la autoestima baja, la posibilidad de aumentarla con todos éstos ejercicios es muy viable, si te pones a trabajar frente al espejo y vas perfeccionando cada vez que lo repites, eso te ayudará a actuar más seguro en las situaciones de tu vida y con ello elevar tu autoestima. Debes actuar como si tuvieras autoestima alta, y de actuarla te lo vas a creer y será verdad.

Ahora observa en qué eres bueno, qué haces con mayor eficacia, reconoce tus atributos, cualidades y habilidades, escribe en la siguiente tabla lo que se te pide.

\begin{tabular}{|c|c|c|}
\hline \multicolumn{3}{|c|}{ Atributos, Cualidades y Habilidades } \\
\hline DOS ATRIBUTOS FÍSICOS & DOS CUALIDADES & DOS HABILIDADES \\
\hline & & \\
\hline
\end{tabular}

Reflexiona: sobre la dificultad que tuviste para identificar tus cualidades, habilidades y atributos, es muy importante ser positivos respecto a la manera en cómo te ves y cómo te trates, pues te ayudará a vivir mejor y a tener mejores relaciones interpersonales.

Modificar algo de ti, lleva tiempo; no se logra de la noche a la mañana. Pero si lo intentas necesitas hacer un gran esfuerzo, comprometerte y hacerlo de manera constante. Puedes recurrir a amigos u otras personas de tu confianza para compartir ideas y sentimientos; sin embargo, si consideras necesario, puedes buscar ayuda profesional. 
Mejora tu calidad de vida y rendimiento académico a través del autoaprendizaje

Recuerda: eres inmensamente valioso eres un bloque de un mármol fino, esperando deshacerte de toda la piedra que cubre tu grandeza. Pero no esperes que llegue a tu vida un escultor. Tú debes ser el escultor. Debes estar seguro de que eres tu mejor escultor, sean cuales sean tus defectos, son más grandes tus cualidades que posees y tienes el talento para hacerlo, tienes muchos talentos más de los que te imaginas... Además tienes un compromiso contigo para ser mejor, te lo garantizo, por eso estás trabajando aquí y ahora.

\section{Si lo Crees “lo Ves, iClaro Que Sí!“}

Te propongo lo siguiente, haz una lista de:

1.- Dos cosas que haces bien y que disfrutas hacer:

2.- Un logro reciente:

3.- Una frase que te gustaría que te dijeran: " "

Reflexiona: relacionando estás respuestas con la forma en que te relacionas con los demás sirve de espejo, reflejo, pues es más fácil ver las fallas en el otro que en ti mismo. Es más fácil culpar al otro, que darte cuenta y preocuparte por los propios problemas. Así son las relaciones con los demás; autoestimarte lleva a estimar a los demás (Rodríguez, 1988).

Ahora bien, una vez que ya reconoces varias de tus cualidades, habilidades y logros te preguntarás y ahora ¿cómo logro aceptarme y valorarme tal como soy? Para ello, te planteo varias actividades, que te recomiendo practicarlas lo más que puedas, haciendo tus anotaciones de cada ocasión en que la realices y vayas notando tu avance.

1. Dedica tiempo para trabajar en ti y por ti mismo: es fundamental que pienses en cómo eres y cómo te gustaría ser, qué decisiones tomas y qué necesitas. Recuerda qué lo que hagas de tu vida te afecta a ti y a los demás. Puedes tener una autoestima alta cuando realmente reflexiones, sientas, te aceptes y actúes cómo eres; cuando internamente estés satisfecho contigo mismo.

2. Se honesto contigo mismo: reconoce tus defectos (ya que aceptarlos te ayuda a trabajar para cambiarlos) y tus cualidades (son tus herramientas para lograr mejorías 
y cambios), lo que haces bien es gol y lo que haces mal, aunque no te guste, porque te motiva a trabajar. Esto te permite darte cuenta que tienes muchas cualidades que sirven como motor para lograr cosas en tu vida. Además reconoce que nadie es perfecto y que la práctica hace al maestro, de manera que si no te salió a la primera tendrás varias oportunidades para aprender. Imagina un niño pequeño que está aprendiendo a caminar, no lo hace perfecto a la primera, varias veces se cae, pero se levanta y sigue haciéndolo hasta que lo logra, así nos pasa a todos cuando aprendemos a hacer algo nuevo. Hay momentos en los que tu percibes que alguna persona o situación te incomoda, y te dices, no si son mis cuates y ya he venido a este lugar antes, esa es una señal para que en ese momento te detengas- frecuentemente cuando sigues adelante algo ocurre de manera negativa y te sientes muy mal, porque no creíste en ti.

3. Ten disposición para cambiar: creces con una imagen de ti mismo y piensas que así debes ser toda tu vida; sin embargo, tienes experiencias nuevas que te hacen otra persona, capaz de cambiar y mejorar. Debes atreverte a dejar ideas o pensamientos que ya no te sirven y a adquirir otros que reflejen lo que ahora eres; a hacer lo que no habías hecho, a decir lo que no habías dicho y a sentir lo que no habías sentido. Debes aprender nuevas formas de relacionarte con los demás de manera sana y positiva.

4. Sé paciente y constante: no puedes cambiar tan rápido; debes ser paciente, no desanimarte y reconocer que puedes equivocarte y aprender de tus errores.

5. Siente seguridad de ti mismo: necesitas que la seguridad salga de tu interior y eso se logra siendo congruente con quien eres, lo que haces y la imagen que proyectas a los demás. La única manera de que seas seguro es estando en paz y armonía.

6. Acéptate tal como eres: es importante evitar pensamientos negativos sobre ti mismo, compararte y también evita comportarte de acuerdo con lo que esperan los demás de ti. Debes revisar tus características positivas aceptarlas y si es posible reforzarlas, respecto a las negativas aceptarlas o intentar cambiarlas, en virtud de que la aceptación es el paso inicial para superar los problemas. Así mismo, puedes adquirir nuevas habilidades que requieres para las nuevas acciones que deseas realizar.

7. Muestra respeto hacia ti mismo: el primer paso es no criticarte (cuando estás en proceso de cambio volverás a actuar como lo hacías, al inicio te darás cuenta después de que ya lo hiciste, sin embargo eso es bueno porque estás identificando el momento, 
posteriormente pararás a la mitad o al inicio y finalmente antes de actuar ibravo, felicidades lo lograste! Estás teniendo el control), pues entre más lo hagas, es menos probable que te equivoques. Trata de evitar esa "voz interior" que te juzga, es un derrotero, y en su lugar considerar que todo lo que haces es importante y merece respeto, con lo cual tu voz interior también hará el cambio.

Seguramente en varias ocasiones has escuchado una de las siguientes frases: "ama a tu prójimo", "Haz con los otros lo que quieras para ti", "No hagas a otros lo que no quieras para ti". Es en tus respuestas y actitudes como te vas conociendo; a través de todos los papeles que vives es como te irás descubriendo, conociendo, aceptando, respetando y valorando (Renny y Agosesky, 1999). Todo esto te hace crecer, ya que tienes la oportunidad de desarrollar tu persona y comprenderte, y así incrementar tu autoestima, motivando así a tener más cambios positivos. Según sea tu autoestima, será la imagen que tengas de ti mismo. Recuerda que la autoestima y la asertividad son procesos dinámicos, que si no te gustan los puedes mejorar, de hecho esa es la intención de esta guía, ayudarte en este camino del fortalecimiento y el bienestar.

Ahora bien, una vez que ya sabes lo que necesitas para tener una buena autoestima te propongo este ejercicio:

¡Quiérete y decídete a cambiar! Elije una conducta o hábito que te moleste de ti mismo y que deseas cambiar. Posteriormente escribe cómo podrías hacerlo y llévalo a la práctica durante una semana.

Para ello, deberás desarrollarlo en una tabla para analizar la conducta elegida a modificar. Con cuatro columnas, en la 1a colocas el día de la semana, en la 2a marcas si ocurrió, en la 3 a cuantas veces y en la 4a en qué situación.

TABla PARA ANALIZAR LA OCURRENCIA de LA CONDUCTA ElEGIDA A MOdificar

\begin{tabular}{|l|l|l|l|}
\hline Día de la semana & Marcas si ocurrió & Cuantas veces & En qué situación y con quiénes \\
\hline & & & \\
\hline
\end{tabular}


Esto es para identificar la conducta problema, el contexto en que se presenta y con qué personas estabas, a fin de que vayas teniendo control sobre ella y puedas cambiarla. Lo primero es saber cuándo y con qué frecuencia ocurre y la segunda es decidir detenerla cuando empieza a ocurrir ("ahí te dices alto" y si es necesario visualizas un semáforo en rojo y lo dices verbalmente, sobre todo al principio), lo que vas a hacer, es detenerla cada vez más rápido, hasta que logres hacerlo antes de que se presente y finalmente verás que ya no se presenta.

Es importante destacar que existe una relación estrecha entre autoestima y trascendencia en las relaciones interpersonales en el aquí y en el ahora. Y como base, estas dos grandes capacidades: la capacidad de amar y elegir. He aquí nuestra libertad -“sólo podemos respetar, dar y amar a los demás cuando nos hemos respetado, dado y amado a nosotros mismos" (Maslow).

Por último, te recomiendo que practiques que espero te ayuden a que desarrolles tu autoestima. Colócalos en un lugar visible, para que los recuerdes y los emplees al actuar:

- Valórate y aprecia lo que haces. Identifica al menos 5 ocasiones en las que hayas realizado actividades importantes, al menos para ti y hayas tenido una buena ejecución. En este momento siéntate y cierra tus ojos, visualiza la primera situación que escribiste y vela lo más vívidamente posible y metete a la situación, siente que estás ahí, pon atención a lo que escuchas y te dices a ti mismo, siente la sensación de plenitud que experimentas, respira y saborea el momento es decir hazlo tuyo con todos tus sentidos, eso lo hace más poderoso. Ahora guarda esa sensación que fortalece tu autoestima y es una herramienta contra un no puedo, bastará con que te sientes y sientas toda esta sensación y por ningún momento tendrás dudas de que puedes., respira suave, profunda y lentamente, regresando al presente, disfruta esta sensación en todo tu cuerpo. Cuando pase puedes trabajar la siguiente o hacerla en otro momento.

- Acepta tus defectos y virtudes. Haz una lista y al lado de los defectos ve la manera de cambiarlos, puedes hacer primero el ejercicio anterior, y después te visualizas con ese 
Mejora tu calidad de vida y rendimiento académico a través del autoaprendizaje

defecto y empiezas a notar que se va desvaneciendo y aparece en su lugar la virtud que habías escrito en tu lista.

- Exprésate siempre en forma positiva. Y afirmativa. Deja atrás la crítica y la negatividad. Rabindranath Tagore (1882) dijo "si tu silencio dice más que tus palabras no lo rompas".

- Al cometer errores: reconoce que eres humano y busca solucionar tus errores, ofrece disculpas, retribuye el bien perdido o dañado y realiza la promesa de poner atención y evitar que esto ocurra en otra ocasión.

- Descubre y destaca las cosas que te gustan de ti. Disfrútalas y acreciéntalas, y visualízate haciéndolas y sintiéndote pleno y feliz.

- Di frases como "yo puedo" o "soy capaz de" aquellas cosas que no te atreves a realizar, y admiras en alguien más.

- Sé optimista, ante las situaciones más difíciles, al menos concédete la duda de si podrás, sin embargo, con lo que has estado trabajando has visto que si puedes, sobre todo cuando te lo propones, lo trabajas a conciencia y lo logras, así que el optimismo es parte importante de tu vida.

- Evita hacer las cosas siempre en función de lo que otros esperan, es aburrido, si lo haces porque tú quieres, a ti te interesa, notarás que lo disfrutas y te sientes muy bien y entusiasmado y el resultado frecuentemente mejora, porque no te preocupa.

- Comunica abiertamente tus necesidades y cómo quieres que te traten los demás. Recuerda que la asertividad te ayuda a expresar lo que deseas de manera adecuada y directa, ayudándote a obtener lo que deseas, sin embargo también debes reconocer que tú puedes pedir y el otro puede decir bien o sabes que eso no me gusta y no lo deseo hacer.

- Sólo actúa y di lo que piensas, sé auténtico. Y disfruta de todo lo que haces y todas tus relaciones, con ello, tendrás bienestar.

- Haz una lista de lo que necesitas para sentirte seguro cada día, y conforme lo vayas logrando, ve tachando lo que ya conseguiste y actúa como si ya lo hubieras logrado. Y el mejor seguro es el que te da el sentir que tú realmente disfrutas ser quien eres, lo que tienes y lo que haces, eso te ayuda a tener y hacer otras cosas, tienes más oportunidades. Debido a que te sientes pleno y seguro. 
4 Elementos para Establecer Relaciones Interpersonales Positivas

- Forma álbumes con lo que has logrado, con los recuerdos de tu vida que muestren lo que te gusta hacer y lo que es importante para ti. Resaltando tus experiencias de logro, de felicidad, bienestar y plenitud.

- Haz una lista de los recuerdos positivos de los últimos años, y revívelos como en el ejercicio primero de esta secuencia, para revivirlos de manera plena.

\section{RESPONSABILIZÁNDOME DE MI AsERTIVIDAD}

3a Habilidad ASERTIVIDAD. Exprésate claramente respetando a los demás.

\section{"Tus derechos terminan donde empiezan los de los demás"}
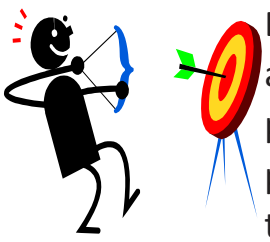

Es necesario que aprendas a decir lo que sientes o piensas de una forma amable, sencilla y tomando en cuenta a los demás. En muchas ocasiones, puedes sentirte presionado por otros compañeros, y buscar su aprobación para sentirte integrado a ese grupo. Tu labor es a aprender a expresarte de tal manera que te sientas seguro y tranquilo de que serás respetado. Muchas veces no dices lo que piensas por pena, temor o inseguridad, como: cuando quieres quedar bien con el chico que te gusta y aceptas su invitación a probar alguna bebida, aun sabiendo el peligro que corres.

Frecuentemente supones, porque así has aprendido, qué decir lo que piensas y sientes está mal, que se debe hacer todo lo posible para no lastimar a otros; sin embargo, esto puede ocasionar que no haya una comunicación clara y no expreses lo que realmente quieres y algo muy importante que quien salga lastimado seas tú.

Antes de continuar te invito a que realices este ejercicio. Piensa en una situación en la cual no te sentiste capaz de expresar lo que sentías y pensabas frente a otros... Posteriormente escribe lo más fiel posible las razones por las cuales no defendiste tus derechos y no mostraste tus verdaderos sentimientos.

Reflexiona: ¿Qué paso?, ¿Por qué no te defendiste? ¿Qué o quién te detuvo?... piensa un momento y analiza si te gustan este tipo de situaciones. Si respondiste que no, pues este 
Mejora tu calidad de vida y rendimiento académico a través del autoaprendizaje

el primer paso para cambiar y abrir la puerta de la asertividad y así mejorar la forma en que te relacionas.

A continuación te describiré la manera general de cómo lograr expresarte claramente.

¿Qué implica expresarte sin anteponer a los demás? Quiere decir que expresas lo que sientes o piensas de manera sincera y clara, poniéndote a ti en primer lugar, estas reconociendo y defendiendo tus derechos y considerando a los demás, pero para no lastimarlos, ni pasar por sus derechos.

Es importante que aprendas a expresar sentimientos como el enojo, la alegría, la ternura, el entusiasmo; a responder ante las críticas y a negarte a hacer algo que no deseas, evitando dar respuestas evasivas, inventando pretextos o diciendo si y no lo haces; o bien con respuestas agresivas (en la que la mejor defensa es el ataque, y no tomas en cuenta las necesidades de los otros) o pasivas (que busquen adaptarse a lo que los otros quieren sin tomar en cuenta lo que tú pienses o necesites), en una sola palabra, se trata de falta de ASERTIVIDAD.

En pocas palabras, el que una interacción te resulte satisfactoria depende de que te sientas valorado, respetado y esto a su vez no depende tanto del otro, sino que poseas esta habilidad "ser asertivo" para responder correctamente y una serie de convicciones o esquemas mentales que te hagan sentirte bien contigo mismo (Castanyer, 2010).

Y ahora te preguntarás ¿Qué necesito para lograr ser asertivo?

Es importante desarrollar la habilidad de expresarte clara y honestamente, sin afectar a los demás. Un buen inicio es que destaques la importancia de aprender a conocerte; de esa forma, si lo haces podrás expresarte sin tener que esconderte "detrás de una máscara" para quedar bien con los demás.

Para ello, te propongo dos ejercicios: 
4 Elementos para Establecer Relaciones Interpersonales Positivas

Primeramente te invito a que pienses y escribas numerosas cosas o situaciones que: 1) te gustan, 2) no te gustan, 3) en los sentimientos que te generan y 4) necesitas o deseas.

Esto con la intención de conocerte más y saber cómo responder ante situaciones que te desagradan. Frecuentemente los acontecimientos donde puedes observar que la asertividad se te fue de las manos es en situaciones de enojo para ello te propongo realizar lo siguiente:

Completa las oraciones relacionadas a situaciones en que te enojas, con el máximo de respuestas específicas posibles, entre más mejor, en virtud de que te permite conocerte mejor:

a) Llego a enojarme cuando...

b) Cuando me enojo yo digo...

c) Cuando me enojo yo hago...

d) Cuando alguien se encuentra cerca de mí y está enojado, yo...

e) Consigo controlar mi enojo mediante...

Reflexiona: ¿Qué tal te fue, haz un estimado de las ocasiones en que llegas a sentirse enojado, molesto o irritado (por semana o día). Estos estimados anótalos en tu cuaderno y reflexiona acerca de la cantidad de enojo que puedes experimentar.

Las personas asertivas canalizan su agresividad negativa u hostil a través de los deportes, ejercicios físicos, o de relajación, o por actividades que permiten la salida de esa energía acumulada.

Ahora bien una vez que ya identificaste las situaciones en que no logras ser asertivo, puedes tomar en cuenta las siguientes recomendaciones, para así facilitarte la convivencia con los demás (SSP, s/f); te sugiero que las revises a conciencia e identifiques situaciones en tu vida. Escríbelas y déjalas en un lugar visible y a tu alcance; a fin de que lo revises y puedas aplicarlo en tu vida diaria: 
Mejora tu calidad de vida y rendimiento académico a través del autoaprendizaje

Identificar el deseo, sentimiento o pensamiento que requieres comunicar como: "Prefiero no ir por ellos, estoy con mucho trabajo".

Aceptar y comunicar con firmeza y cortesía lo que se siente en lugar de fingir lo que otros esperan: "¿Saben qué?, no estoy interesada; mejor me voy a mi casa".

Considerar y respetar al otro: "Entiendo y respeto tu decisión, pero no estoy de acuerdo contigo".

Buscar el lugar y el momento apropiado para expresar lo que quieres decir: "Ahora que estamos tranquilos quiero hablar contigo".

Pedir sin temor lo que quieres en vez de pedir permiso para hacerlo: "Necesito realizar una tarea extra, así que no te podré acompañar".

Dar a conocer las razones por las cuales se toma la decisión: "Considero que es peligroso; no nos va a dejar nada bueno".

No es necesario justificar lo que haces y porqué o haces o sólo decir: No asisitiré al evento, así que puedes organizarte.

- Responsabilizarse y asumir las posibles consecuencias: "Sé que me comprometí a entregar el proyecto, tuve complicaciones y no lo tengo listo sino hasta mañana, creo que hay una penalización que la cubriré al entregar".

Hablar en forma clara, breve y directa: "Necesito que me auxilies para organizar esto, que las visitas están por llegar y ando apurado terminando de cocinar", en lugar de "Tú siempre estás en la luna".

Ahora que ya conoces como puedes lograr la asertividad te propongo algo: ponerlo en práctica, así que te invito a realizar el siguiente ejercicio:

\section{¿Qué harías tú si...?}

Lee cada situación que te aparece a continuación y escribe en tu cuaderno cómo responderías ante esa situación.

Eres un chico adolescente que llega tarde a su casa después de ir al cine con sus compañeros de escuela. Tus padres estaban muy preocupados por no saber de ti. ¿Cómo les responderías si al llegar a tu casa te llaman la atención? 
4 Elementos para Establecer Relaciones Interpersonales Positivas

Tienes un maestro que es muy enojón y no acepta sus errores. Acabas de darte cuenta de que calificó mal tu examen, por lo que bajó tu promedio general. ¿Cómo actuarías en este caso?...

$>$ Te encargaron un trabajo en equipo. Son tres los integrantes; sin embargo los otros dos siempre tienen compromisos y no han podido reunirse. Mañana es la fecha de entrega y no te queda más remedio que hacerlo solo. Justo cuando lo terminas te hablan por teléfono y te piden que los anotes pues tuvieron problemas familiares y no habían podido contactarte. Eso te parece injusto. ¿Qué haces?...

Reflexiona: te pregunto ¿Se te facilitó expresarte claramente dándote tu lugar, reconociendo tus derechos y respetando a los demás? Si tu respuesta fue afirmativa, me alegro, sigue así y no tendrás problemas en tus relaciones. Si por el contrario se te complico, tal vez esté ahí la causa de que no puedas relacionarte como tú deseas, así que te sugiero que vuelvas a releer los ejercicios antes mencionados.

Otra característica de las personas asertivas, es que suelen pedir lo que necesitan, dicen lo que les gusta, expresan lo que sienten cuando es necesario. Tienen siempre presente el: ¿Para qué? ¿Para qué lo digo? Como: lo digo para informar, darme a conocer o para humillar, lastimar o reclamar. Si este ¿Para qué? No responde a algo positivo es mejor callarse y revisar sus actitudes y sus emociones, la responsabilidad y el respeto, para uno y los demás

Ser asertivo significa poner en práctica las habilidades propias respetando los derechos de los demás, (como se menciona al principio de este apartado). ¿Derechos? Si derechos asertivos. Estos derechos están escritos, pero muchas veces los olvidas o en ocasiones ni los conoces. 


\section{DERECHOS ASERTIVOS}

1. Tienes derecho a: ser el primero, sin obsesionarte si no lo eres. Sin ceder siempre el lugar a los demás. Comunicar tus deseos o preferencias. No digas "Io que quieras" cuando tengas una preferencia.

2. Tienes derecho a cometer errores. Los errores forman parte de la vida, son necesarios para el aprendizaje. No te avergüences por ellos y defiende tu derecho a cometerlos.

3. Tienes derecho a: tener tus propias opiniones y creencias. Tener una opinión distinta a la mayoritaria no implica estar equivocado, iquizá justo lo opuesto!

4. Tienes derecho a: cambiar de idea, opinión, o actuación. Cambiar de opinión no es una traición a ti mismo, es evolucionar, aprender, ser flexible.

5. Tienes derecho a expresar críticas y a protestar por un trato injusto, pero siempre de forma respetuosa a los demás.

6. Tienes derecho a intentar cambiar lo que no te satisface. No te digas a ti mismo que no lo lograrás, si no lo has intentado.

7. Tienes derecho a pedir ayuda o apoyo emocional.

8. Tienes derecho a sentir y expresar el dolor. Todos sentimos dolor, y tienes derecho a expresarlo ante aquellas personas que son importantes para ti, si lo necesitas.

9. Tienes derecho a ignorar los consejos de los demás. Cuando alguien te da un consejo es precisamente eso, nunca una orden de actuación.

10. Tienes derecho a recibir el reconocimiento por un trabajo bien hecho. Reconoce tus méritos. Esto se aplica a los demás, pero sobre todo a ti mismo.
11. Tienes derecho a negarte a una petición, a decir "no" sin sentirte culpable o egoísta. Decir "no" no te hace desleal o egoísta.

12. Tienes derecho a estar sólo, aun cuando los demás deseen tu compañía.

13. Tienes derecho a no justificarte ante los demás. En ocasiones con un "No, gracias" es suficiente. No tienes por qué dar excusas y menos si no son sinceras.

14. Tienes derecho a no responsabilizarte de los problemas o necesidades de los demás.

15. Tienes derecho a no anticiparte a los deseos y necesidades de los demás y a no tener que intuirlos.

16. Tienes derecho a ser tratado con dignidad. Cuando sientes que no eres tratado con la dignidad y el respeto que mereces, tienes derecho a protestar por ello.

17. Tienes derecho a tener tus propias necesidades y que sean tan importantes como las de los demás.

18. Tienes derecho a experimentar y expresar tus propios sentimientos, así como a ser tu único juez.

19. Tienes derecho a detenerte y pensar antes de actuar.

20. Tienes derecho a pedir lo que quieres y a aceptar un no por respuesta.

21. Tienes derecho a hacer menos de lo que eres capaz de hacer. No siempre puedes rendir al máximo.

22. Tienes derecho a decidir qué hacer con tu cuerpo, tiempo, y propiedad. 
4 Elementos para Establecer Relaciones Interpersonales Positivas

Es importante que conozcas los derechos y los lleves a la práctica, estos te permiten relacionarte con los otros de mejor manera y expresarte de forma adecuada:

Realiza un ejercicio por escrito imaginando que aplicas cada derecho en al menos cinco situaciones de tu vida.

Reflexiona: ¿Te costó trabajo, hubo algún derecho que te costara más trabajo? Piensa en cada derecho asertivo, de esta manera, podrás aplicarlo más fácilmente.

En este punto, haz una lista de situaciones que te causan dificultad y para cada una de ellas plantéate: ¿Qué derechos te estas saltando y no estas teniendo en cuenta en tus relaciones?

Recuerda que al desarrollar y practicar esta habilidad tendrás mayor ventaja para relacionarte con quien tú quieras. Su importancia radica en el beneficio personal, familiar y social que tiene llevarla a la práctica.

\section{Optimizando Mı Comunicación}

\section{4a Habilidad LA COMUNICACIÓN. Es la base de las buenas relaciones.}

Hablando se entiende la gente.

Uno de los aspectos más importantes de las relaciones entre las personas es la comunicación, ya que a través de ella logras intercambiar ideas, experiencias y valores; transmitir sentimientos y actitudes y conocerte mejor. La comunicación te permite expresarte y saber más de ti mismo, de los demás y del medio en que vives.

La comunicación te sirve para expresar lo que sientes, lo que necesitas y lo que piensas de los demás, para entender el mundo que te rodea y para ser escuchado; también, para conocer a las personas con las quien te relacionas diariamente. La mayor parte de tu vida te la pasas conviviendo con los otros, por lo que es importante aprender a comunicarte y para así relacionarte mejor. 
Mejora tu calidad de vida y rendimiento académico a través del autoaprendizaje

Cuando se es joven los principales problemas en las relaciones son por problemas de comunicación tales como: falta de comprensión sobre la importancia de la comunicación; falta de compromiso; diferencias culturales; problemas de comunicación de género; incapacidad de escucha activa y escucha selectiva; diferentes definiciones de límites y estrés, entre otros.

Pide a un amigo, hermano, o cualquier persona que te ayude en este ejercicio, dile que se ponga en frente tuyo de manera que queden cara a cara, indícale que "al darle la señal deberán hablarse uno al otro continuamente sin parar, ambos deberán hablar al mismo tiempo, de lo que sea, ino tiene que tener sentido!, los dos deberán seguir hablando, durante 5 minutos, hasta que suene la chicharra" activa tu timer, a fin de que les marque el tiempo.

Reflexiona: ¿Cómo te sentiste?, ¿Te dieron ánimos de seguir hablando?, no verdad. Pues esto sucede en una comunicación cuando no existe una escucha activa y por ende tiendes a tener problemas para relacionarte.

Te preguntarás ¿cómo se pueden superar estas dificultades? ¿Por dónde empezar? Aprendiendo tres habilidades básicas y sencillas:

1. Escuchar

2. Observar

3. Hablar.

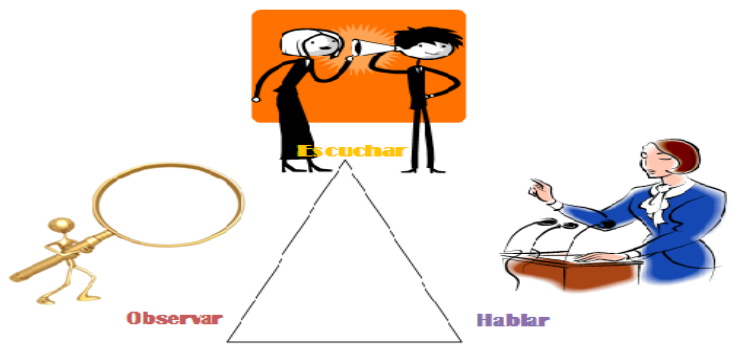

Escuchar: Saber escuchar es lo más importante en una plática, pero también puede ser lo más difícil de hacer. Dices que se estás escuchando, pero al mismo tiempo oyes la radio, ves televisión o voltea para otra parte sin poner atención a la persona quien te está hablando. 
Cuando alguien se te acerca a comentar una situación que le afecta, te corresponde escuchar; sin aconsejar; cuando tú eres quien tiene el problema y quieres comentarlo, debes expresarlo sin atacar o culpar, utilizando mensajes directos y claros en 1 a persona del singular, como: "cuando me sucede... yo me siento...", "yo percibo..."

Ahora realiza este examen para que evalúes si escuchas correctamente.

\section{"EXAMEN DEL OYENTE” (Gerza, s/f)}

Esta lista de comprobación te ayudará a calificar tus propios hábitos de escuchar. Trata de responder a cada pregunta de modo objetivo con una " $\mathrm{X}$ " en la columna correspondiente:

Cuando tomas parte en una conversación o conferencia de grupo:

1.- ¿Te preparas físicamente sentándote frente al locutor, cerciorándote de que lo puedes oír?

2.- ¿Observas al locutor al mismo tiempo que lo escuchas?

3.- ¿Decides juzgar por la apariencia y modo de expresarse del locutor si lo que tiene que decir vale la pena o no?

4.- ¿Escuchas buscando primordialmente ideas y sentimientos subyacentes?

5.- ¿¿Puedes parafrasear lo más importante del mensaje?

6.- ¿Mantienes tu mente en lo que está diciendo el locutor?

7.- ¿̇Interrumpes inmediatamente, cuando oyes una manifestación que consideras está equivocada?

8.- ¿Te cercioras antes de responder que has comprendido el punto de vista de la otra persona?

9.- ¿Tratas de decir la última palabra?

10.- ¿Haces un esfuerzo consciente para evaluar la lógica y credibilidad de lo que oyes?

\begin{tabular}{|l|l|l|}
\hline $\begin{array}{c}\text { Por lo } \\
\text { general }\end{array}$ & $\begin{array}{c}\text { Algunas } \\
\text { veces }\end{array}$ & Nunca \\
\hline & & \\
\hline & & \\
\hline & & \\
\hline & & \\
\hline & & \\
\hline & & \\
\hline
\end{tabular}


Para evaluar tu nivel de escucha a las preguntas 1, 2, 5, 6, 8 y 10 asígnales 3 puntos si tu respuesta fue: "Por lo general"; 2 puntos si fue: "Algunas veces"; y 1 punto si fue: "Nunca". En tanto que para los reactivos 3, 4, 7 y 9 les asignarás 1 punto si tu respuesta fue "Por lo general", 2 puntos "Algunas veces"; $y$, 3 puntos si fue: "Nunca". Posteriormente suma todos los puntos y busca ese valor en la siguiente tabla, para que veas que tan desarrollados tienes tus hábitos de escucha.

\begin{tabular}{|l|l|}
\hline \multicolumn{2}{|c|}{ Puntuación del Examen del Oyente } \\
\hline $9-16$. & $\begin{array}{l}\text { Deficiente. Te sugiero poner en práctica los ejercicios que te propongo para } \\
\text { mejorar tu comunicación. }\end{array}$ \\
\hline $17-23$ & Regular. No está de más Seguir uno que otro tips para mejorar tu comunicación. \\
\hline $24-30$ & Muy Bien. Sigue así, pero no está de más saber más del tema llevar a la práctica. \\
\hline
\end{tabular}

Reflexiona: Si después de este examen tuviste resultados que no te gustaron, piensa sobre cuáles son los principales problemas que tienes y te sugiero, practicar los siguientes TIPS, para que desarrolles la habilidad de escuchar: Presta atención: si de verdad quieres escuchar a alguien es importante interrumpir lo que se estabas haciendo y concentrarte en lo que el otro está diciendo sin juicios ni crítica; Mira a los ojos a la persona con quien hablas; Identifica los sentimientos que la persona está expresando al hablar, como: enojo, tristeza, ansiedad; No interrumpas a la otra persona hasta que termine su idea, ni estés pensando en qué le vas a responder. Ponte en el lugar de la otra persona, ve las cosas desde su punto de vista para comprenderlo; y, No juzgues nunca, sólo debes analizar la situación.

También del pasado se aprende con las herramientas del presente. Ahora una vez que ya leíste los tips para mejorar tu comunicación. Piensa en una o más conversaciones en tu vida que terminaron mal. Imagina cómo estas conversaciones habrían ido mejor con el escuchar más responsivamente. Escribe tu versión alternativa de la conversación.

La segunda habilidad que debes desarrollar para comunicarte mejor es la observación. 
4 Elementos para Establecer Relaciones Interpersonales Positivas

Observar: aparte de lo que expresas con las palabras, tu cuerpo también habla en todo momento; da mensajes siempre. Si estas contento, triste, aburrido o de malas, estos estados de ánimo son vistos por los demás.

Reflexiona: A veces parece que la falta de comunicación es un problema de tiempo, siempre se está de prisa. Te propongo este plan:

\section{Unos minutitos...}

La próxima vez que hables con alguien de tu familia, tus amigos, tus compañeros de escuela, con tus maestros o con alguien que conoces, escucha atentamente todo lo que tenga que decir (aplicando los elementos de los tips anteriores), por lo menos durante tres minutos. No interrumpas, sólo muestra tu interés por medio de gestos y de una mirada atenta. Si pones atención, puedes recibir más información de la que oyes, pues también tomarás en cuenta los gestos, la mirada y el movimiento del cuerpo.

Repítelo al menos una vez al día. Y observa las diferencias en tu comunicación y en las actitudes que muestra tu ponente. En cada día, al sentirse escuchado.

Con estas dos habilidades te reto a que realices este ejercicio:

Responderás esta prueba durante 3 minutos, es importante que la realices sólo en este tiempo.

Prueba de 3 minutos.

Instrucciones:

1. Lea todo antes de proceder.

2. Pon tu nombre en la esquina superior de esta hoja.

3. Encierra en un círculo la palabra nombre de la oración 2.

4. Traza 4 cuadros pequeños en la esquina superior izquierda de esta hoja.

5. Pon una $X$ en cada cuadro. 
6. Pon tu firma o nombre debajo del titulo de esta hoja.

7. Trace una $X$ en la esquina superior de esta hoja.

8. Dibuje un triángulo alrededor de las $\mathrm{X}$ que trazo.

9. En la parte posterior de esta página multiplique $70 \times 30$.

10. Dibuja un círculo en la palabra HOJA de la oración número 4.

11. Cuando llegues a la parte de este cuestionario di tu nombre e voz alta.

12. Si piensas que has seguido cuidadosamente las instrucciones grita "las he seguido".

13. En el reverso de la hoja sume 107 más 208.

14. Si ha llegado hasta aquí grita "soy el mejor siguiendo instrucciones".

15. Ahora que ya has terminado de leer cuidadosamente: Haz únicamente lo que dice el número 2.

Reflexiona: ¿Respondiste a todas? o ¿Seguiste adecuadamente las indicaciones? Con esta experiencia que puedes concluir, si realizaste todas las oraciones es necesario que apliques los tips de escuchar y los de observar (que en un momento te los daré). Recuerda: que para tener mejores relaciones es muy importante que establezcas una comunicación adecuada, pues si se distorsiona puede influir negativamente en tus relaciones.

Lee a conciencia las siguientes recomendaciones, en virtud de que las puedes utilizar para que conozcas cómo se expresa tu cuerpo y así logres relacionarte mejor.

(:) Una mirada dice más que mil palabras. Mirar directamente a los ojos de quien te habla demuestra que tienes interés y atención por lo que te está diciendo; pero mantener una mirada directa y fija durante mucho tiempo puede ser agresiva, así que ve a los ojos y sigue su expresión corporal sin perder la mirada, pero no incomodes con tu mirada.

(;) Tu cuerpo habla. Abrir los brazos demuestra que estás abierto a recibir al otro con alegría. Cuando cruzas los brazos o las piernas, se puede interpretar como que estas aburridos o no quieres hablar con nadie. Pon atención a cada movimiento del cuerpo, así aprenderás a conocerte y a conocer a los demás. 
(:) Los movimientos de tu cabeza. Cuando dices que sí con la cabeza quiere decir que entiendes y estás de acuerdo; con un ligero movimiento de cabeza hacia adelante le dirás a quién escuchas que te interesa lo que está diciendo.

(:) ¡Habla con las manos! ¿Has escuchado esta frase? Existen personas que cuando hablan mueven mucho las manos; es una manera de expresarse y también de comunicar muchas cosas. Por ejemplo: juguetear con objetos indica nerviosismo, golpear el pie en el suelo puede expresar impaciencia, un apretón de manos puede transmitir seguridad, gusto, sinceridad y honestidad.

(:) Conecta tu ojo, tu oído y cerebro, a fin de que no te dejes lleva por las reacciones automáticas como: el caso de responder todo, si la instrucción fue "Lee todo antes de proceder".

Observar te sirve para conocerte, pero también para saber más de las personas con quienes hablas, pues te pueden comunicar muchas cosas sin decir una palabra.

La tercera y última habilidad, es la de saber transmitir lo que queremos informar es decir, hablar, expresarte verbalmente.

Hablar: expresarte con la palabra permite presentar un tema de manera organizada y clara, convencer a quien te escucha que tienes dominio de ese tema, así mismo, compartir tus sentimientos, dudas y temores, opinar y participar; por eso debes prepararte para expresarte adecuadamente, al hablar todos te entiendan y puedas tener buenas relaciones.

Para lograr dominar el hablar de manera clara y coherente sobre cualquier tema, debes leer y hacer ejercicios en los que presentes un tema, para ti mismo o a alguien más. Considerando los 5 Pasos para Mejorar tus Habilidades como Orador planteados por Nuñez Montenegro (s/f):

Afirmando que, hay un secreto para empezar: cuando estés preparando la presentación debes tener en cuenta siempre que, lo que escribas (el mensaje) para luego hablarlo (o escribirlo) debe ir al encuentro de las necesidades, problemas y expectativas de los 
Mejora tu calidad de vida y rendimiento académico a través del autoaprendizaje

oyentes; el tema principal debe ser desarrollado de manera lógica, clara y entrelazada armónicamente. Y plantea los

- Paso 1: Selecciona un tema que te apasione y que domines. Lo mejor será que hables de lo que llevas años preparando con base a tus estudios, investigaciones o experiencia cotidiana. O bien puedes hablar sobre un tema de actualidad, aplicado a tu área de conocimientos; un tema del que te hayas ganado autoridad probada; o simplemente de un tema que te guste, de una afición, de los que tengas información. También puedes traer temas viejos que han interesado a las personas y presentarlo con nuevos matices.

- Paso 2: Determina los objetivos que deseas alcanzar con la presentación. Como todo en la vida, debes saber para dónde vas si deseas llegar a ese lugar. Para elegir el rumbo antes ha de elegir tu destino. Presentarás un tema a un grupo de personas ¿Qué esperas lograr cuando estés con ellos, cuando ellos se marchen a sus casas?

Los objetivos pueden ser de varios tipos. El primero informar, transmitir información nueva o renovada sobre el tema. Otro objetivo podría ser persuadir, motivar $y$ estimular a tus oyentes para tomen acción de algún tipo. Un tercer motivo podría ser simplemente entretener a tus oyentes, pasar un buen momento con ellos. Un cuarto objetivo vendría a ser estimular una reflexión acerca de un tema de interés común o de una causa. Finalmente un quinto objetivo podría ser promoverte como profesional experto ante el público.

- Paso 3: Conoce bien qué deseas comunicar y motivar a la gente quien recibirá tu mensaje. Tanto el tema como la presentación deben ir acordes con el auditorio quien te dirijas. En cada aspecto de la charla debes tomar en cuenta quiénes son las personas (la edad, el sexo y el nivel sociocultural) que te escuchan y cuáles son los objetivos que pretenden lograr. Es muy importante considerar aspectos: el tipo de vocabulario, la extensión, el significado de los gestos, el volumen e intensidad de la voz, que estés tranquilo, que veas a los asistentes a la cara y la cantidad de información que será transmitida según el objetivo de la charla, pero también conforme a las expectativas y necesidades del auditorio al quien le vayas a presentar.

- Paso 4: Sigue un proceso serio de investigación y preparación de la charla. Forma un archivo bien identificado con todo el material que reúnas. Siempre mantente 
concentrado en el tema central de tu conferencia. Organiza, consolida y relaciona la información recopilada.

Cuando tengas todo esto listo, redacta el contenido de la conferencia. Hazlo en el orden lógico que se acostumbra: Introducción. Esta es la parte del discurso en la que te dedicas a conquistar al público, los saludas y debes capturar toda su atención. Puedes aludir a la ocasión, tratar de conquistar al público indiferente y bajar el tono del público hostil; Preparación. Este es el momento en que informas a los oyentes sobre cuál será el tema y a dónde pretendes llegar. Explicas la división de los temas y cómo los irás presentando; Tema Central. Aquí es en donde desarrollas el tema principal y ofreces la información completa de la conferencia. Puedes presentarla ordenada en función de una escala de tiempo o de espacio, u organizada según causa y efecto. Utiliza elementos de transición para facilitar la comprensión del mensaje. Finalizando esta parte, agregamos argumentaciones sólidas de refutación; y Conclusión. En esta parte cierras el tema. Procedes con la recapitulación que resume la información presentada en una o dos frases. Agregas un epílogo que se dirija a los sentimientos y cierras con una frase poderosa que haga un llamado a la reflexión, a la acción o que refuerce tu posición sobre la base del objetivo que te habías planteado.

- Paso 5: Practica, practica y practica tu presentación. Esto es lo fundamental. Debes aprovechar cada oportunidad para practicar, no sólo la conferencia como un todo, sino también parte de la presentación, haz lo posible por grabarla en audio y video. O ten una persona de confianza que te de sus opiniones luego. La introducción, la preparación y la conclusión se deben practicar muchas veces, son parte fundamental de la conferencia. El contenido y presentación pueden ser excepcionales, pueden presentarse brillantes y con soltura, pero las partes que la gente más recuerda como experiencia acumulada y como valor agregado se reafirman en la introducción, en la preparación y en la conclusión.

Practica en privado pon en práctica los cinco puntos clave para la conferencia completa. Mide los tiempos. Analiza cambios en la presentación que requieran refinamiento. Posteriormente, trata de presentar la charla a un grupo pequeño. Pueden ser amigos, 
Mejora tu calidad de vida y rendimiento académico a través del autoaprendizaje

colegas o un grupo de referencia modelo en menos escala. Cuando se presente la oportunidad de brindar la conferencia estarás mucho más preparado si has practicado antes.

Reflexiona: sobre estas preguntas ¿Cuáles son tus mejores cualidades para hablar?, ¿Cuáles son tus defectos para hablar?

Una vez descubiertas tus habilidades y defectos te propongo realizar el siguiente ejercicio para que seas más consciente de los aspectos que se te facilitan / dificultan para hablar. $Y$ caer en la cuenta de que es normal.

Te doy otro ejercicio para que practiques tu capacidad de hablar. Pídeles ayuda a 2 personas de tu confianza. Una vez reunidos, imagina que tienes que practicar una exposición, , a uno de tus amigos y el otro observará y hará notas con respecto a la manera en que se desarrolla la comunicación entre ambos. Después de 5 minutos se rotaran, de manera que a cada uno le toquen los 3 papeles: el que habla, el que escucha y el que observa. Quien escuchó le comenta a quien habló si considera que su comunicación fue clara, o si no lo fue, especificando en qué no lo fue: si manejaba el tema, si tenía coherencia su exposición, si tomaba en cuenta a su interlocutor si lo veía, le preguntaba, lo escuchaba, si tenía buen manejo del énfasis, si era un tono de voz plano, si hacía movimientos con las manos, el cuerpo y la cara. De igual manera el observador da en cada caso sus impresiones, considerando los siguientes elementos:

\begin{tabular}{|l|c|c|c|}
\hline $\begin{array}{c}\text { ¿Mensaje fue } \\
\text { claro? }\end{array}$ & $\begin{array}{c}\text { ¿La postura fue } \\
\text { coherente? }\end{array}$ & $\begin{array}{c}\text { Las frases empleadas } \\
\text { ayudaron a la } \\
\text { comunicación }\end{array}$ & $\begin{array}{c}\text { Tono de voz al dar el } \\
\text { mensaje }\end{array}$ \\
\hline & & & \\
\hline
\end{tabular}

Reflexiona: recuerda que, la comunicación interpersonal implica un conjunto de habilidades que te permiten comunicarte de forma efectiva con los demás, expresando 
4 Elementos para Establecer Relaciones Interpersonales Positivas

qué sientes y quieres transmitir y escuchando a los otros, aceptando las diferencias de opiniones y respetando otros puntos de vista y derechos.

Y debes saber que: Hablar Implica:

is Hablar con el cuerpo: sonreír, mirar a los ojos, tomar la mano o el hombro, dar un abrazo, tener un tono de voz cálido y suave nos ayuda a comenzar una plática.

¿t Utilizar frases para iniciar la comunicación: ¿Cómo te fue?, ¿Qué hiciste... el fin de semana, o en vacaciones?, ¿'Fuiste al cine?

is Para dar continuidad a una conversación que se detiene se puede decir: "Te escucho", "cuéntame más", "quieres decirme algo", "me decías", ¿Sí?

is Durante la conversación: usar palabras claras, precisas, frases cortas y comentar sólo lo relacionado con el tema.

is Ser concreto y directo: se dice exactamente lo que se quiere, que el otro no tenga que adivinar. Y se tendrá una comunicación adecuada sin malos entendidos.

is Manejar oraciones positivas y afirmativas hasta donde sea posible, evita palabras que hieran, palabras ofensivas o que cierran la comunicación: como dar consejos, o soluciones.

is Realiza preguntas cuando tengas dudas o necesites clarificar algo, cuando haya una incongruencia, puedes decir algo como: "haber, ya me perdí, me dijiste que... y ahora me dices lo opuesto, me puedes aclarar para que te siga".

is Parafrasea lo que escuchas, es decir ponlo en tus palabras, usando frases como: "haber si te entendí...", "lo que dijiste fue que..."

Recuerda continuar practicando en cada ocasión que se te presente o que crees, ya que la práctica hace al maestro y entre más dominio tengas, mejor podrás actuar en los eventos y actividades de estudio, de trabajo o de familia.

\section{CLARIFICANDO Mis VALORES}

\section{5a Habilidad VALORES}

Para Nina Bravo (1995) la humanidad entera se está enfrentando a un gran problema, no 
Mejora tu calidad de vida y rendimiento académico a través del autoaprendizaje

una crisis de valores, como se ha querido afirmar, sino, a una relativización total de ellos. Tú sabes que algo pasa, intuyes que no decides bien, pero no sabes por cual filtro pasar tu propia percepción, de ti, de lo que te rodea, y menos de los estímulos que te bombardean constantemente: iideologías, modas, publicidad! Hablas de los valores, pero si te pregunto ¿Qué son?, probablemente no podrías definirlos. ¿Cuáles son?, podrás mencionarme los que recuerdes que te inculcaron tus padres o tu escuela o tu vida...

Te reto a que hagas una lista de 10 .

Y ahora cada vez que quieres tomar decisiones, te preguntas ¿Está bien, estará mal lo que estoy haciendo? ¿Es justo, es injusto? Miles de cuestionamientos de la vida cotidiana, que te hacen notar que es necesario tener una guía, un horizonte, una claridad que no encuentras y que, a veces, por los resultados, ves que fueron alternativas erróneas las que elegiste, por ejemplo no te diste el tiempo necesarios, que fuiste poco prudente, o quizá demasiado reservado y ial final no hiciste nada!

Y así, tal vez es un poco de tu vida de hoy, poco clara, poco sólida, vas y vienes a las circunstancias. Tal vez, eso no te gusta....

Quieres cambiar lo que piensas y lo sientes, pero no sabes cómo hacerlo. Te faltan las herramientas, las habilidades, la forma. Esa es mi idea que encuentres en estas páginas como llevar a cabo "el éxito de las relaciones interpersonales", encontrando un camino para evolucionar y que diversas maneras estés relacionando con el tema de valores

\section{¿Qué son los Valores?}

Hay muchas definiciones dictadas ya por pensadores muy antiguos, donde aparecen dos posiciones muy fuertes pero antagónicas, que se mantienen hasta el día de hoy.

Una posición señala que los valores son metas. Ideales que puede alcanzar el hombre. Para ellos los valores son objetivos, no están sujetos a la cultura, al tiempo, a la ciencia ni a otras variables. Son externos al hombre, no dependen de él, están de acuerdo a la ley natural son inmanentes, trascendentes y atemporales, por ejemplo: el amor (Remolina Vargas, 2005). 
4 Elementos para Establecer Relaciones Interpersonales Positivas

Así mismo, Remolina, menciona que la segunda postura plantea que los valores son subjetivos, que dependen de la valoración que cada hombre les dé, de acuerdo a su marco de referencia (cultura, edad, sexo, educación, religión), que cambian con la historia y el momento circunstancial, incluso hasta en el estado de ánimo. Esto es lo que se está viviendo ahora. El mundo es valorado de acuerdo a la propia percepción.

El hombre es un permanente descontento consigo mismo es una eterna búsqueda sin encontrar respuesta a los por qué y los para qué, que le plantea su existencia.

Pareciera entonces que se tiene que mirar profundamente y descubrir todos los valores que se posee.

Para ello, te invito a que realices el siguiente ejercicio:

\section{Mi personaje favorito}

"Todos tienen un "Héroe", es decir, una persona a quien admiran. A veces se trata de alguien conocido solamente en nuestro ámbito familiar, y en otras ocasiones, de alguien que goza de fama nacional o mundial. Lo admiras por sus talentos, por sus valores, por su entrega y capacidad de servicio o por su aspecto físico. Hoy vas a buscar en tu vida a quien admiras". Piensa en una de esas personas luego escribe de quien se trata y también las razones que te llevan a sentir admiración por ella o él.

Reflexiona: ¿Para qué te sirvió lo que hiciste? ¿Qué cosas importantes te permitió conocer de ti? ¿Cuáles son los valores más importantes para ti?

De acuerdo a tus propios valores es como asignas ciertas características de los demás, porque es como tú las percibes y tus valores influyen en todo momento de tu vida y en la motivación que tienes hacia ella.

Ahora bien una vez que identificas tus valores necesitas de 3 llaves (Bravo, 2001) como prerrequisito, para que reproduzcas y lleves a la práctica tus valores: 
1a llave Pensar: Eres racional, tienes inteligencia para conocer, comprender y adaptar, además de muchas funciones de la mente, como imaginación, memoria, creatividad, evaluar, discriminar y valorar. Al pensar se toman decisiones muy medidas y balanceadas, perfectamente analizados los pros y los contras y se posee el poder de actuar bajo control voluntario.

2a Ilave Sentir: Todas tus emociones y sentimientos, como la capacidad de amar, asombrarte, extasiarte o aburrirte. Cuando se exalta el sentimiento y domina, es cuando se dejan llevar por un impulso, frecuentemente por emoción, una pasión como gano México y se van al Ángel y están súper contentos, cantan y bailan, pero siguen y empiezan a destrozar, hasta que les echan agua fría o macanazos; o en la ira, en la que por una pequeñez golpean a alguien tanto que lo dejan muy mal herido o pueden seguir hasta matarlo.

3a llave Actuar: Es decir, llevar a cabo lo que piensas y sientes. Es ejecutar, es realizar el poder de tu voluntad. Al actuar, tienes los dos extremos, ser muy controlado y tomar decisiones fríamente calculadas; o bien, actuar con la inconsciencia, sin pensar ni analizar posibles consecuencias y después vienen los problemas y la culpa. Sin embargo por más que ofrezcan disculpas el daño se realizo, y como dicen, después del accidente nada es igual, queda una fuerte huella en la relación.

Ahora, te llevaré a imaginar situaciones en la que no usas estas 3 llaves...

\section{a) ¿Qué pasa si Sientes y Haces, pero no piensas?...}

Tal vez, conoces mucha gente que es así, y a lo mejor muchas veces tú también lo haces... Son personas de acción y reacción. Son los que se tiran a la piscina seca, porque no vieron si tenis agua. Son los impulsivos, viscerales, tienen rabia y pegan.

Piensa en alguna situación en que te dejaste llevar por un impulso, ¿qué hiciste y qué consecuencias obtuviste? 
Los valores radican en la inteligencia: son hábitos operativos adquiridos, aprendidos. Si no usas la inteligencia, serias más bestia que cualquier animal, ya que ellos poseen el instinto de su especie. Nosotros tenemos impulsos, no instintos puedes gobernarlos con inteligencia y voluntad.

¿Cuántas veces compraste un libro que nunca leíste? Si abres tu closet, ¡Cuántas prendas cuelgan, porque no te resististe al impulso de comprarlas! pero que después viste que no combinaban con nada o simplemente ya no te gustaron cuando llegaste a tu casa. ¡Dejaste guardada tu llave de la inteligencia!

\section{b) ¿Qué pasa si se te olvida usar la llave de la voluntad?}

Sabes que no has organizado tu vida, te sientes descontento con eso, pero, no haces nada y vives lamentándote. Nada te resulta...

¡Ni ordenarte, ni seguir una dieta, ni guardar un secreto, ni leer el libro que te propusiste, o terminar las cosas que te dejaste a medias...!

Perteneces a la orden de los constructores de castillos en el aire, de los flojos, los soñadores, los utópicos. Estas mintiéndote constantemente a ti mismo y eso hace que tu autoestima baje y baje hasta sentirte más pequeño. Te sientes frustrado y te irritas por todo y peleas contra todo mundo, es más cómodo hacer responsables a los demás, que reconocer que no estás haciendo lo que necesitas, que es ejercer tu voluntad de manera responsable. iSe quedó guardada la llave de la voluntad!

Encuentra situaciones en las que hayas actuado de esta manera, a lo mejor en alguna época de tu vida, es importante que lo reconozcas, para que lo puedas trabajar y superar. Después de plantearlo, establece como lo puedes superar, ¿Cuál sería su contraparte?, que te reflejaría lo que debes fortalecer.

c) Te parece raro que no se pueda no usar la llave de los sentimientos, pero desgraciadamente así es. Ahí se puede descubrir a los duros de corazón, a los arribistas 
Mejora tu calidad de vida y rendimiento académico a través del autoaprendizaje

a costa de los demás, a los insensibles, prepotentes, a los nada empáticos, crueles, egocéntricos. Frecuentemente son personas que fueron lastimadas y colocaron un escudo o barrera, para que no se repita y esconden sus sentimientos, con ataques a los demás. ¿Te horroriza? Es algo que se ve a cada rato y que tal vez, también te pase a ti. ¡No usas la llave del sentir!

Es importante que reflexiones en posibles situaciones en las que has actuado de alguna o varias de las formas planteadas o de alguna en la que pienses que entra en esta categoría, Cuando lo identifiques, trata de encontrar que ocurrió que pudiera haber generado el que tú te encerraras sin mostrar tus sentimientos y cómo crees que hiciste para salir de esa situación, y si aún debes trabajarlo: siente la emoción que te embarga en este momento, reconócela y busca expresarla de alguna manera adecuada, que si es enojo, puedes romper papeles y sentir que toda la furia se va en eso trozos, puedes ponerte a correr, a jugar tenis, futbol, caminata prolongada, en fin alguna actividad física que te ponga en movimiento intenso, y puedes gritar lo más fuerte que puedas y puedes gritar Jo Jo Jo todo el tiempo que quieras y necesites, después te sentirás tranquilo y con posibilidades de comunicarte y expresar tus sentimientos de manera saludable.

Te darás cuenta ahora, que para abrir la puerta a los valores hay que usar las 3 llaves simultáneamente, si se te olvida una nunca podrás alcanzar el umbral del éxito en tus relaciones que tanto anhelas.

Y como saber que posees o utilizas las 3 llaves. Simplemente realiza el siguiente ejercicio:

\section{Ruleta de Valores.}

Instrucciones: Ordenar por rangos y grados de importancia.

1. ¿Qué es más importante en la amistad? Lealtad. Generosidad. Rectitud.
2. ¿Si le dieran $50,000.00$ pesos qué haría con ellos? Ahorrarlos. Comprar algo personal. Darlos a una obra benéfica. 
3. ¿Qué cree que sea más perjudicial? El alcohol. La marihuana. El tabaco.

4. ¿Si fuera padre, a qué hora dejaría a sus hijos de 14 años fuera?

A las 22 horas.

A las 24 horas.

Dejarlo a criterio del hijo.

5. ¿Qué sería lo último que le gustaría ser? Muy pobre. Muy enfermo. Sin vida social. Desfigurado.

6. ¿Qué le gusta más?

El invierno en las montañas.

El verano en la playa. El otoño en el campo.

7. ¿Qué es lo que más desearía mejorar? Su apariencia.

El aprovechamiento de su tiempo. Su vida social

8. ¿Cómo se la pasaría mejor?

Solo.

Con un grupo grande.

Con pocos amigos.

9. ¿Cuál sería el acto más espiritual o religioso que podría hacer un domingo en la mañana? Ir a la iglesia y escuchar un buen sermón.

Oír un concierto de música clásica. Tener un buen desayuno con su familia.
10. ¿Cuál de las siguientes medidas deberían tomarse para aligerar el problema de la explosión demográfica?

Legalizar el aborto.

Permitir que los padres tengan dos hijos y luego esterilizarlos.

Distribuir información sobre control de la natalidad.

Confiar en el buen sentido de las familias para determinar el número de hijos.

11. ¿Si heredara una fortuna qué haría?

Repartir su riqueza en beneficio de otros.

Continuar con su mismo trabajado y actividades.

Cambiar totalmente de vida.

12. ¿Qué le resultaría más fácil hacer?

Una campaña para organizar una cena de Navidad para un orfanatorio.

Hacer trabajo voluntario en un hospital. Asesorar a un grupo de estudiantes.

13. ¿Cuál cree que sea el problema interior más serio de su país?

La prevención de la criminalidad.

La beneficencia pública.

La inflación.

La libertad política.

14. ¿Si fuera confinado a una isla desierta, cuál de los siguientes libros llevaría consigo? La Biblia. Las obras completas de Cervantes. La historia de la civilización. 
Mejora tu calidad de vida y rendimiento académico a través del autoaprendizaje

15. ¿Qué preferiría perder si tuviera que hacerlo?

La libertad económica.

La libertad religiosa.

16. ¿En cuál de los siguientes periodos históricos piensa que podría haber sido un líder eficiente?

En la colonización de América.

En la Revolución Industrial.

En la Segunda Guerra Mundial.

17. ¿Cuál de los siguientes cursos le gustaría tomar?

Educación Sexual.

Relaciones sociales.

Ecología.

18. ¿Cuál de las siguientes expresiones describe mejor la forma en que usa el dinero? Lo gasta despreocupadamente.

Siempre busca negocios.

Lo gasta con cuidado.
19. ¿Qué le disgustaría más?

Perder su trabajo.

Perder su dinero. Romperse una pierna.

20. ¿A quién prefiere como vecino? A un ciego. A un paralítico. A un anciano.

21. ¿Qué es lo más trabajo le cuesta hacer? Levantarse temprano. Organizar su trabajo del día. No estar tenso durante el día.

Reflexiona: en tus respuestas, ¿Evaluaste las consecuencias y conductas que tendría tu elección?, ¿Buscaste alternativas de otras opciones?, ¿Refleja este orden como actúas o representa la persona que desearías ser?

Si dedicas tiempo a revisar y a reflexionar sobre los valores, puedes adoptar decisiones mejores y más conscientes sobre tu vida, tu escuela o trabajo y tu conducta será equilibrada $y$ coherente.

Personalmente no conozco a nadie que haya dicho que quiera ser infeliz, que quiere fracasar. Por ello, la importancia de que, las 3 llaves tengan coherencia y armonía totales entre ellas. Debes pensar, sentir y actuar en la misma dirección ¿Cuántas veces te has encontrado pensando una cosa, sintiendo otra y haciendo otra? El resultado es que tu ser y tu psique está quebrada. Eso pasa cuando no eres libre en tu interior. 
Elegir implica un conocimiento profundo de tu pensar, sentir y hacer. Si no eliges, te convertirás en un esclavo de ti mismo y eso es grave. ¿Quieres saber cómo se hace? Para ello te recomiendo que al tomar alguna decisión responde a lo siguiente de la manera más honesta y sincera: Sentir es percibir lo que te ocurre internamente o las reacciones de lo que ocurre externamente en tu entorno; hacer es cuando tú decides actuar de cierta manera responsablemente, pensando y analizando todas las posibles alternativas y sus consecuencias favorables y desfavorables, asumiendo hacer lo que tiene resultados más positivos y/o con menos efectos negativos.

Ahora reflexiona: ¿Qué es lo más importante para mí? Y respóndete antes de actuar. Plantéate una situación en la que tengas que actuar, 1ㅇ piensa que tantas formas tienes de hacerla, se creativo; 2 - reflexiona sobre cada una de las posibles acciones, y ponle a un lado signos de + o de --, de acuerdo a las posibles consecuencias, si son positivas + y si son negativas-; y para descartar, inicia eliminando las que tienen más signos -, y selecciona la que tenga más elementos + .

Para finalizar este tema, te recuerdo, que Integridad es la suma de:
$\infty$ Convicciones.
$\infty$ Parámetros.
$\infty$ Creencias.
$\infty$ Conductas.

Quien es coherente con sus valores es una persona íntegra.

\section{MARCANDO MIS LÍMITES}

\section{6a Habilidad PONER LÍMITES}

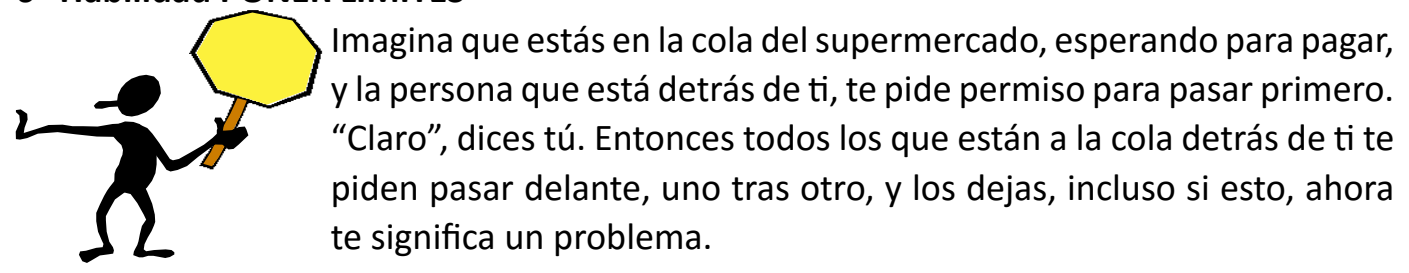


La posibilidad de vivir felices depende de tu capacidad de saber hasta qué punto puedes ceder ante otros o poner freno a los comportamientos que consideras inapropiados, incluso destructivos para ti. Para eso existen los límites.

Un límite es algo que te define. Del mismo modo que las paredes de tu casa definen el espacio donde habitas, los límites emocionales son líneas importantes y necesarias.

Una de las situaciones difíciles que a lo mejor viviste en tu infancia dentro de tu hogar, es el no haber tenido límites funcionales claros, tal vez, creciste sin una verdadera estructura o con paredes y murallas movibles.

Los límites son como vallas invisibles y simbólicas de tienen 3 propósitos:

1. Impedir que las personas penetren en tu espacio y abusen de ti.

2. Impedir que tú entres en el espacio de otra persona y abusar de ellos.

3. Proporcionarte un modo de respetarte y hacerte respetar.

Te invito a que realices este ejercicio y detectes si eres vulnerable. Siempre si - siempre no.

Se divide una hoja en 3 partes, en una de ellas se pondrá como titulo: familia, en otro: amigos y en la tercera pareja.

๑ Anota en cada zona correspondiente preguntas que recuerdes respecto a situaciones con la familia, amigos y pareja que sean difíciles de negar o afirmar. Puedes preguntarles a varias personas para que tengas un amplio número en cada una.

\begin{tabular}{|l|l|l|}
\hline \multicolumn{1}{|c|}{ Familia } & \multicolumn{1}{|c|}{ Amigos } & \multicolumn{1}{c|}{ Pareja } \\
\hline $\begin{array}{l}\text { ¿Tienes relaciones sexuales? } \\
\text { ¿Me prestas dinero? }\end{array}$ & $\begin{array}{l}\text { ¿Vamos a una fiesta? } \\
\text { ¿Soy tu mejor amigo? }\end{array}$ & $\begin{array}{l}\text { ¿Me amas? } \\
\text { ¿Soy buen amante? } \\
\text { ¿Me eres infiel? }\end{array}$ \\
\hline
\end{tabular}


4 Elementos para Establecer Relaciones Interpersonales Positivas

Teniendo un número considerable de preguntas en cada área, pregúntate todas, de manera continúa teniendo que contestar a todo de manera afirmativa.

\& Posteriormente, haz una segunda ronda, en donde contestes a todo no.

\& Por último realiza una tercera ronda, donde contestes con la verdad.

Reflexiona: ¿Cómo te sentiste al estar en una situación donde estás obligado a contestar de manera afirmativa o negativa sin ser realmente la respuesta? Reflexiona: cómo y dónde has vivido estas situaciones.

Si tienes miedo de decir "no", miedo a perder el amor, a perderte a ti mismo, miedo a decir "si" a algo por no saber cómo poner límites. ¿Qué puedes hacer, entonces?

Como el caso de: Lorena, quien sentía un profundo disgusto por las bebidas alcohólicas. Su padre bebía demasiado, y su hermano mayor murió arrollado por un conductor ebrio. Aunque su abuelo no podía obligar a sus hijos adultos a no beber, se negaba por completo a permanecer en la misma habitación o incluso en la misma casa con alguien que estuviera bebiendo. Sus límites eran muy claros. Si querían compartir un rato con ella, debía ser sin alcohol de por medio.

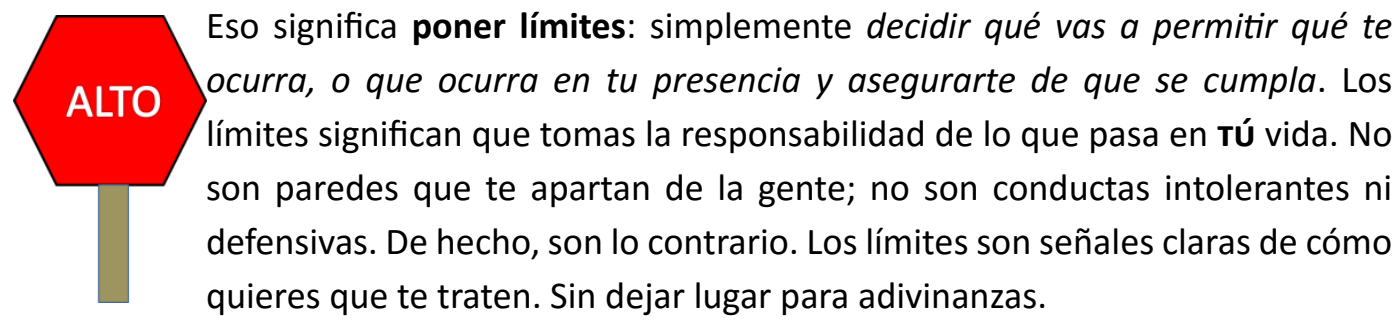

Y tú ¿estableces tus límites? 
Mejora tu calidad de vida y rendimiento académico a través del autoaprendizaje

\section{Contacto visual}

Te propongo realizar este pequeño ejercicio. Pídeles a 2 personas que te apoyen. La primera debe de ser alguien de tu confianza y la segunda alguien que apenas conozcas. Necesitarás un metro de hilo.

H Ponte frente al compañero de tu confianza, teniendo contacto visual, cada uno tomará un extremo del hilo.

H A una señal empezarán a enrollar el hilo hasta que tú digas "basta". Mide el trozo de hilo que quedó sin enrollar.

If Ahora, en esta ocasión, realiza nuevamente el ejercicio, pero con la otra persona.

Reflexiona: ¿Quién se te acerco más? ¿Por qué la cercanía de unos más que de otros?, ¿Qué sucede con el contacto visual?, ¿Por qué con algunos es más fácil que con otros?

Dentro del tema de los límites se pueden diferenciar dos tipos: límites externos e internos. Los límites externos:

\& Te permiten escoger la distancia respecto a otras personas y decir hasta dónde quieres que se acerquen o que no se acerquen del todo.

\& Impide también que con tu cuerpo le hagas daño a otra persona.

\& Los límites externos sanos te dan una buena idea donde terminas tú y donde empieza el otro.

Un ejemplo de conducta que demuestra falta de límites es la insistencia de tener relaciones sexuales cuando la pareja ha dicho que no.

\section{Límites internos:}

Protegen tus pensamientos, sentimientos y conductas, manteniéndolos funcionales.

- Asumes la responsabilidad por tus pensamientos, sentimientos, emociones y conductas; sin confundirlos con los de otras personas y sin culpas por lo que piensas, sientes y haces. 
4 Elementos para Establecer Relaciones Interpersonales Positivas

- Te permiten sentirte responsable por ti y por ningún motivo por los pensamientos, sentimientos, emociones y conductas de otras personas, con lo cual también dejas de manipular y controlar a quienes te rodean.

Una persona sin límites, no percibe los límites de los otros. Con límites externos e internos flexibles es posible tener relaciones más definidas y de diferente grado de intimidad, sin tener que salir corriendo, esconderte o culpar, manipular o controlar, o crear estrategias para impedir que las personas se acerquen demasiado, marcando claramente el alto cuando se inicia una situación riesgosa.

\section{Recuerda: El mundo respetará tus límites si les indicas donde están.}

\section{No puedo-no quiero}

Te propongo que realices este ejercicio para que seas consciente de tu responsabilidad de las decisiones y acciones que tomas:

(2) Escribe 5 frases que empiecen con 'no puedo...', que se refieran a tu vida familiar, académica, social... como: "no puedo decirle a un amigo que me molesta que comente lo que yo le confío".

(-) Luego, escribe 5 frases con no puedo relacionarme con...

(-) Ahora, lee en voz alta las frases que escribiste. Una vez hayas leído tus frases, reléelas en voz alta las frases reemplazando el 'no puedo' por 'no quiero' por ejemplo "no quiero decirle a un amigo que me molesta que comentó lo que yo le confié" y así sucesivamente con todas tus frases.

Reflexiona: Te das cuenta de que el "no puedo" implica muchas veces algo que es posible, pero que te rehúsas a hacer algo, inventando pretextos y el "no quiero" afirma la responsabilidad de tus decisiones y acciones, en dónde tú eliges no hacerlo y lo asumes, sin mentiras ni cuentos.

Si no pones límites, te expones a sufrir resentimiento, frustración, ira, desacuerdos y depresión. "Un momento", me dirás; "no puedo forzar a la gente a que me trate bien". Y es 
cierto: tú no puede cambiar a los demás, ni obligarlos a que se comporten correctamente. Tratar de cambiar a otros sólo te creará más resentimiento y frustración. Pero lo que puedes hacer es que cuando las cosas van en un sentido indeseable para ti, les dices: si continúas haciendo eso me retiro, si sigue te retiras.

Seguro te preguntarás ¿Cómo puedes establecer límites?

Puedo sugerirte cuatro modos de establecer límites efectivos:

Decide qué está bien para ti y qué no. Ésta es una decisión personal. Lo que para ti es correcto puede ser incorrecto para otros. Decide por ti mismo.

Piensa en cómo vas a manejar la situación si tus límites se ven violados. Por ningún motivo trates de probarlo poniendo una emboscada a la persona, pon un alto y marca no quiero que me trates así.

中 Escoge una manera de proteger tus límites. Esto significa que lo que digas o hagas traerá alguna consecuencia. Si es posible, concéntrate en las consecuencias POSITIVAS de obtener cooperación, y deja las negativas. Asegúrate que las personas que te rodean conozcan esas consecuencias a tiempo.

Reflexiona: Esto es fundamental; de otro modo, simplemente estarás jugando con el otro, y demostrándole que a ti no se te puede tomar en serio. Decide cuáles son los puntos en que vale la pena mantenerte firme y imantente firme!

Para poder establecer relaciones que te sean satisfactorias y para que puedas arreglar las conflictivas es necesario examinar tus límites. La gente llega a abusar de ti hasta donde tú le permitas. De manera que es necesario que hagas una reflexión y precises todas aquellas cosas que estás permitiendo a los otros, que te permitiría cambiar, o al menos que NO estas dispuesto a seguir aceptando. Y eso puede hacerse independientemente del tipo de relación en que estés involucrado.

* Vivir en pareja (o con personas muy cercanas) por ninguna causa significa que hay que perder u olvidarse de los proyectos personales, hobbies, amistades o familiares, 
4 Elementos para Establecer Relaciones Interpersonales Positivas

siempre que estos no choquen con los objetivos y el proyecto común de la relación. Tampoco significa que uno de los dos tenga, por imposición del otro, que hacerse cargo de algo que NO quiere hacer.

* Ser madre o padre por ningún motivo te da el derecho de abusar o coartar la libertad de sus hijos; tampoco tienen los hijos de abusar de los padres o coartar su libertad. Por mucho amor que se pueda tener hacia un padre y por supuesto a un hijo, siempre será necesario aclarar y poner los límites.

En un contexto laboral, escolar o en general, vale la pena actuar asertivamente para hacer valer tus derechos, porque aunque siempre exista el riesgo de ser despedido, hay más posibilidades de que seas respetado y tratado como justamente te mereces, ya que, aceptar maltratos o humillaciones de un superior, nunca te garantiza que permanecerás en el empleo, sin embargo si garantiza que el maltrato y abuso se harán más fuertes y tú te sentirás devaluado.

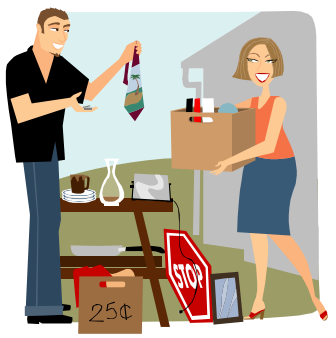

Reflexiona: que siempre serás responsable de las cosas que permites a los demás. Por lo tanto depende de ti generar los cambios, en lugar de quedarte lamentando, esperando que los otros cambien. Simplemente se trata de que busques un adecuado equilibrio en todas y cada una de tus relaciones. $Y$ si hay alguien muy negativo y hasta violento, no querrás estar cerca de él.

¿Estás listo para afrontar este cambio? Libérate del resentimiento, la impaciencia, los celos, los enfrentamientos y las frustraciones de tu vida. Establece tus límites CON SERENIDAD. Verás como las cosas empiezan a cambiar para bien.

Una vez terminada esta guía y realizado todas y cada una de las actividades te pido nuevamente realizar el cuestionario del principio y evalúes si tuviste cambios satisfactorios. En caso de que no fuera así, revisa en que fue y debes trabajar nuevamente.

¡Te deseo que tengas éxito y que vivas feliz con tus relaciones! 



\title{
Diálogos con amor: comunicación en pareja
}

\author{
Tania Ivett Hernández Granados
}

$\mathrm{T}$ radicionalmente se ha considerado a la comunicación como un proceso simbólico y transaccional, es decir, un trayecto en donde la conducta verbal y la no verbal funcionan como símbolos creados que permiten compartir significados, interactuar, al mismo tiempo que profundizar en el conocimiento propio y de otras personas (Satir, 1986).

Así, la comunicación representa el medio idóneo para que una persona exprese apertura y obtenga a la vez retroalimentación acerca de sí misma, apoyo, aceptación y confirmación de que es un individuo digno para establecer una relación íntima exitosa. Este mecanismo, actúa como una entidad facilitadora en la emisión de ciertos comportamientos como: la toma de decisiones y el manejo de conflictos, dirigidos a organizar la relación, pues a través de ella, se asignan funciones y papeles, con ello se crea una visión conjunta del mundo (Fitzpatrick, 1988). De esta manera, la comunicación abarca una amplia gama de signos que representan cosas, sentimientos e ideas. De igual forma, durante la comunicación cada uno de los miembros impacta en el otro al compartirle información de índole personal o no personal, lo que crea una realidad particular a cada pareja (Derlenga, 1984).

La pareja es sin duda una de las formas más comunes de relación interpersonal. Que, conlleva un proceso interactivo en el cual se van desarrollando ciertas dependencias y maneras de convivencia, conformadas sobre el tiempo, las experiencias y espacios compartidos (Díaz-Loving \& Sánchez Aragón, 2002). Su dinámica conforma un proceso de cambios complejos, progresivos, estáticos y cambiantes, con oscilación entre períodos de cercanía y distanciamiento (Sánchez Aragón, 1995).

La comunicación dentro de la pareja es fundamental para el funcionamiento de la misma, en cualquier etapa en la que se encuentre, ya que es el medio por el cual se expresan 
Mejora tu calidad de vida y rendimiento académico a través del autoaprendizaje

pensamientos, temores, sentimientos y se solucionan problemas (Armenta Hurtarte \& Díaz-Loving, 2006).

Probablemente todos estamos convencidos de que la comunicación es muy importante para la pareja. El modo en que se dicen las cosas puede alterar la percepción que se tiene del otro e incluso de nosotros mismos. Del mismo modo, la manera en que nuestra pareja se comunica con nosotros puede fortalecer o afectar nuestra propia autoestima (Roche Olivar, 2009). Piensa ¿cómo puedes mejorar la calidad de tu estilo comunicativo?

A continuación te propongo el uso de esta guía, que te enseñará a conocer cuáles son los puntos o elementos característicos de una comunicación con calidad y además te da pautas para identificar cuáles son tus elementos fuertes (a fin de que reconozcas las herramientas y recursos con que cuentas para hacer frente a las situaciones) y de manera especial los débiles (que deberás trabajar para de fortalecerlos y convertirlos en recursos). Si esto lo haces en pareja, los resultados pueden ser sorprendentes. En definitiva, te plantea el desafío de cómo mejorar tu propio estilo comunicativo. El presente es un manual planeado para servir de ayuda para las personas interesadas en mejorar su comunicación con su pareja, y por lo tanto, es para ti. Te recomiendo que tengas un cuaderno o libreta, de tamaño cómodo para traerlo y llevarlo con la guía y trabajar haciendo las anotaciones pertinentes al hacer los ejercicios y puedas revisarlos, a fin de ver tus avances. Es importante que sepas que, cuando veas tres asteriscos $\left({ }^{* *}\right)$ significa que es una actividad para realizar. Así mismo, en algunas actividades se han colocado puntos suspensivos (...) a fin de señalarte que debes realizar una pausa adecuada para trabajar lo que se te acaba de indicar.

\section{CONTENIDO TEMÁTICO}

\section{Aspectos Básicos sobre la Comunicación}

- Elementos de la comunicación

- Formas de comunicación verbal y no verbal

\section{Manejando las Barreras de Mi Comunicación y Relación}

- Físicas 
5 Diálogos con Amor: Comunicación en Pareja

○ Semánticas

- Fisiológicas

- Psicológicas

- Administrativas

3. Habilidades Comunicativas

- Hablar o escribir

- Escuchar o leer

\section{Comunicación y Emociones}

- Conciencia emocional: reconocer las propias emociones

- El control de las emociones

\section{Manejo del Conflicto}

- La empatía

- Respuestas constructivas para la resolución de conflictos en pareja

\section{Amor e Intimidad en la Pareja}

OBJETIVO GENERAL: es que desarrolles habilidades de comunicación que te ayuden a afrontar y solucionar problemas con tu pareja, o bien con personas cercanas.

\section{Aspectos BÁsıCOS SOBRE LA COMUNICACIÓN}

Somos primordialmente seres "sociales", en el sentido de que pasamos la mayor parte de nuestras vidas con otras personas. Por consiguiente, es importante aprender a entendernos con los otros y a funcionar adecuadamente en situaciones sociales. Ciertas habilidades de comunicación nos ayudan a mejorar las relaciones interpersonales.

\section{Elementos de LA COMUNicACIÓN}

La comunicación es el acto por el cual un individuo establece con otro un contacto que le permite transmitir una información. En la comunicación intervienen diversos elementos que pueden facilitar o dificultar el proceso.

- Emisor: La persona (o personas) que emite(n) un mensaje. 
Mejora tu calidad de vida y rendimiento académico a través del autoaprendizaje

- Receptor: La persona (o personas) que recibe(n) el mensaje.

- Mensaje: Contenido de la información que se envía.

- Canal: Medio por el que se envía el mensaje.

- Código: Signos y reglas empleadas para enviar el mensaje.

- Contexto: Situación en la que se produce la comunicación.

*** En las diferentes conversaciones que te toque presenciar, identifica estos elementos de la comunicación y en aquellas que tú participes, pon atención al impacto que tus acciones agregan al mensaje, al modular mejor, al hablar muy rápido, al hablar de temas extraños a los demás, permítete ser creativo, divertirte y haz que todos se diviertan y también que puedan aprender, convirtiéndolo en un juego...

Reflexiona: Con respecto a si has notado la importancia que tiene cada uno de los elementos en una buena comunicación, y especialmente que cuando lo haces más divertido funciona mejor, cuando estás muy serio, formal y rígido la comunicación se vuelve más difícil, porque se le agrega tensión al asunto como parte del contexto.

\section{FORMAS DE COMUNICACIÓN: VERBAL Y NO VERBAL}

La comunicación eficaz entre dos personas se produce cuando el receptor interpreta el mensaje en el sentido que pretende el emisor.

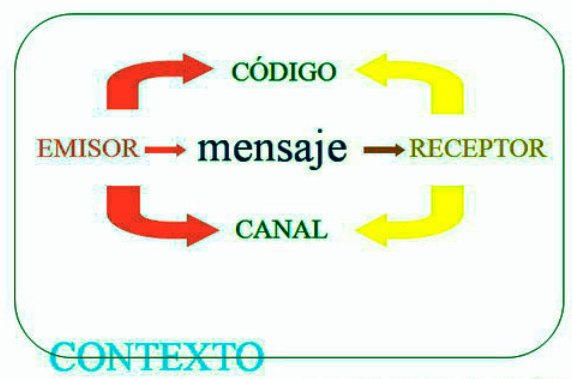

IA COMUNICACIÓN

Las formas de comunicación humana pueden agruparse en dos grandes categorías: la comunicación verbal y la comunicación no verbal: 
5 Diálogos con Amor: Comunicación en Pareja

- La comunicación verbal se refiere a las palabras que utilizamos y a las inflexiones de nuestra voz (tono de voz).

- La comunicación no verbal hace referencia a un gran número de canales, entre los que se podrían citar como los más importantes el contacto visual, los gestos faciales, los movimientos de brazos y manos o la postura y la distancia corporal.

*** Realiza observaciones con todas las personas que puedas, para identificar los elementos de la comunicación expresados anteriormente, analiza los impactos en la comunicación cuando se presentan adecuadamente, cuando faltan elementos o cuando no hay coherencia. Realiza anotaciones en un cuaderno que tengas para ir realizando todas tus notas de la guía.

*** Ahora, de manera intencional, realiza una comunicación con una persona que no sepa de que se trata, sobre el tema que quieras o que salga. Aquí debes iniciar de manera natural, o sea sin hacer manifestaciones corporales y la menor cantidad de gestos posibles, habla de manera que si hagas manejo oral de entonación, pero sólo con las palabras y voz, por 5 minutos, observa a tu acompañante; después de los 5 minutos, cambia el estilo y ahora vas a poner énfasis con lenguaje corporal y con gestos y toda la actitud, nuevamente observa las reacciones de tu acompañante. Al pasar 5 minutos pregúntale si notó alguna diferencia entre la primera parte de la conversación y la segunda; ¿Qué diferencias observó y cómo se sintió? Y realiza tus propias anotaciones de lo que observaste y de lo que te contestó tu acompañante.

Reflexiona: Al comparar los resultados de las respuestas de tu acompañante y las tuyas con respecto a las diferencias en las dos formas de comunicación, así mismo comparen los elementos de comunicación y formas empleadas por las personas a quienes observaste anteriormente. ¿Son coherentes con lo que plantea la literatura? Pese a la importancia que solemos atribuir a la comunicación verbal, entre un $65 \%$ y un $80 \%$ del total de nuestra comunicación con los demás la realizamos a través de canales no verbales, para comunicarnos eficazmente, los mensajes verbales y no verbales deben coincidir entre 
Mejora tu calidad de vida y rendimiento académico a través del autoaprendizaje

sí. De tal manera que cuando nuestras palabras se contradicen con nuestra conducta no verbal, se presentan numerosas dificultades en la comunicación.

Conociéndo Mis Creencias: Después de haber leído qué es la comunicación y sus tipos, te pido que realices el siguiente ejercicio para que te vayas introduciendo al tema de la comunicación en pareja.

***En una hoja anota la siguiente lista de supuestos y pon al lado de cada afirmación una " $A$ ": si estás de acuerdo con la afirmación, una "De": si estás en desacuerdo o una "Du" si estás en duda, luego anota una explicación del porqué de tu respuesta en cada afirmación, si estás en duda también explica el motivo.

\section{Lista de Supuestos:}

1. Discutir constantemente con la pareja es sano para la relación.

2. Platicar con la pareja fortalece los vínculos afectivos.

3. En una discusión hay que alzar la voz para ser escuchado.

4. No es correcto mostrar las debilidades ante la pareja.

5. Si mi pareja me quiere, debe de saber lo que quiero y necesito.

6. Para no iniciar un conflicto, hay que quedarse callado cuando algo nos molesta.

7. Los besos y las caricias no son formas de comunicar.

Analiza tus respuestas, para que te conozcas mejor.

*** Realiza este ejercicio preguntando a tus papás, hermanos, amigos y pareja que es lo que opinan de estas afirmaciones, así podrás darte cuenta de que cada quien tiene sus propias ideas sobre lo que es o debería de ser la comunicación en pareja. Compara tus respuestas con las de ellos, para que entiendas porqué las cosas ocurren de la forma que lo hacen en la comunicación particularmente con la pareja. Puedes comentar con ellos de manera privada, si la persona lo permite, en el sentido que esto le puede ayudar a entender de que manera él o ella ponen barreras a la comunicación. En cuanto realices tu análisis, te darás cuenta de aquellas creencias que has heredado culturalmente y que dificultan tu comunicación; de forma que, sabrás con que empezar tu cambio. 
5 Diálogos con Amor: Comunicación en Pareja

Reflexiona: Al darte cuenta de que, al conocer el origen de tus problemas de comunicación, te permitirá entender que hemos sido educados de formas diferentes. Y cuando encuentras que hay grupos que comparten ideas, eso forma las creencias, que entre más se comparten por generaciones se van canonizando y perpetuando en la cultura. Ya que realizaste el ejercicio puedes trabajarlo un poco más, dado que es importante identificar y establecer acuerdos con las personas que nos interesan, especialmente nuestra pareja, a fin de hablar el mismo idioma.

\section{Manejando las BarReras de Mi Comunicación y Relación}

¿Sabes que son las barreras de comunicación?, ¿Te ha pasado que vas hablando por celular en la calle y se te va la señal, o que estás platicando con alguien y te distraes con algún objeto y no prestas atención?; las Barreras en la Comunicación, o interferencias, son obstáculos que pueden llegar a distorsionar, desvirtuar o impedir parcial o totalmente el mensaje, y se sitúan entre el emisor y el receptor, cuando ambos están en los mismos campos de experiencia. Las barreras de comunicación pueden ser:

Físicas, Semánticas, Psicológicas, Fisiológicas y Administrativas.

Las Barreras Físicas. Son las circunstancias que se presentan, no en las personas, sino en el medio ambiente e impiden una buena comunicación: ruidos, iluminación, distancia, falla o deficiencia de los medios que se utilizan para transmitir un mensaje: teléfono, micrófono, grabadora o televisión, entre otros.

Las Barreras Semánticas. Tienen que ver con el significado de las palabras; cuando no precisamos su sentido, éstas se prestan a diferentes interpretaciones y así el receptor no interpreta lo que dijo el emisor, sino lo que su contexto cultural le indica. Como en el caso en que una persona hace un pedido y dice que lo quiere "lo más pronto posible", esto puede tener diferentes significados, desde la persona que lo entiende como "inmediatamente", hasta la que lo entiende como "rápido pero no es tan urgente". En la pareja es frecuente que usen palabras o frases iguales con un significado muy diferente. 
Mejora tu calidad de vida y rendimiento académico a través del autoaprendizaje

*** Aquí es importante que, cuando identificas una o varias frases, en las que cada uno entiende algo diferente, primero deberá cada uno enlistarlas y describirlas y luego comenten su interpretación y de qué manera lo manejarán ambos. Es decir construyan un lenguaje propio de la pareja.

Las Barreras Fisiológicas. Impiden emitir o recibir con claridad y precisión un mensaje, debido a los defectos fisiológicos del emisor o del receptor. Tales defectos pueden afectar cualquiera de los sentidos. Ya sea en forma total o parcial. Como ocurre con: Alteración de aquellos órganos que constituyen los sentidos, deficiencia en la escritura, lectura, escuchar bajo diferentes estados como el cansancio, efectos de drogas, de inanición, tales estados han generado cambios que no les permiten poner atención y retener la información.

*** Para manejar esta barrera, deben identificar si hay algún problema de algún canal sensorial en cada uno de los miembros de la pareja, en seguida de identificarlos, analicen si es temporal o permanente, y con este conocimientos, planeen que pueden hacer como pareja para superar esas distorsiones.

Las Barreras Psicológicas. Representan la situación interna que incluye el pensamiento, creencias, habilidades, actitudes, emociones, valores, percepción o motivación particulares del emisor y/o del receptor de la información, ocasionada a veces por agrado o rechazo hacia: el receptor o emisor, según sea el caso; el mensaje que se comunica. La deficiencia o deformación puede deberse también a estados emocionales (temor, odio, tristeza, alegría) o a prejuicios para aprobar o desaprobar lo que se le dice, o lea lo que está escrito, no entienda o no crea lo que oye o lee.

***En este caso se procederá como en los anteriores y considerando la información obtenida en la actividad de las creencias, los deberás enlistar y luego analizar, a fin de saber la mejor manera de resolverlo. Y si es posible con la pareja es mejor.

Las Barreras Administrativas. Pueden ser por la falta de planeación, supuestos no aclarados, distorsiones semánticas, expresión deficiente, pérdida en la transmisión y mala 
5 Diálogos con Amor: Comunicación en Pareja

retención, escuchar mal y evaluación prematura, comunicación impersonal, desconfianza, amenaza y temor; o sobrecarga de información o confusión en los roles de hombres y mujer en la relación, deseo de ser quién lleva y ejerce el control en la relación, frecuentemente en sentido tradicional por el hombre.

***Ahora que ya sabes cuales son las barreras de comunicación realiza el siguiente ejercicio que te ayudará a ir detectando cuales son las barreras que interfieren en tu comunicación y relación, para que las manejes lo mejor posible, y puedas tener una comunicación más clara y eficiente.

Es muy sencillo, en este momento entras a tu laboratorio de autoobservación y durante el transcurso de tu día, y si es posible ir anotando en una lista, cuales son las barreras de comunicación que interfieren en tu vida cotidiana, cuántas veces o con qué frecuencia se presentan esas interferencias, con quiénes se presentan, y por último evaluar que tan importante es o era para ti y para el otro recibir o trasmitir ese mensaje que no llegó adecuadamente debido a la interferencia. Y anotas si encuentras otras barreras de tu relación que no sean necesariamente de comunicación.

${ }^{* * *}$ A continuación te voy a dar algunas tareas para evitar o disminuir tus barreras comunicacionales. Encuentra una persona de tu confianza e invítala a jugar, practicando alternativas de comunicación para cada una de las barreras que encontraste, primero pueden escribir las alternativas y luego poniéndolas en práctica y observando los efectos cuando se realiza bien o con fallas.

Reflexiona: Con respecto a la importancia de que estés consciente de que a veces tú mismo provocas estas barreras, es bueno saber identificar cuándo eres quien las provoca $y$ a partir de ello, tomar las acciones pertinentes, a fin de que mejores tu comunicación.

\section{HABILIDADES COMUNicativas}

Las Habilidades comunicativas incluyen aquellas habilidades que se vinculan con el manejo de información y hacen referencia a diferentes procesos cognitivos expresivos. De manera 
Mejora tu calidad de vida y rendimiento académico a través del autoaprendizaje

que Alfaro (2012) considera que incluyen el habla, la escucha, la escritura y la lectura, es decir estás se vínculan con los diferentes medios por los cuales se recibe o emite la información del mensaje de la comunicación.

Así, el habla, es la capacidad de comunicarse mediante sonidos articulados producidos por el aparato fonador, esta habilidad que alcanza su más alta manifestación, en la medida en que despliega un altísimo grado de complejidad y abstracción en lo referente al contenido; la escucha es la capacidad de sentir, de percibir sensorialmente lo que transmite otra persona, comprende el mensaje, este aspecto, exige tomar conciencia de las posibilidades de tergiversación de los mensajes, permitiéndole evaluar la importancia de lo escuchado, respondiéndole acertadamente al interlocutor. Sea lingüístico o musical; la escritura es la expresión que representa una habilidad compleja, que implica conocimientos, habilidades básicas, estrategias y capacidad para coordinar múltiples procesos, experiencias, ilusiones y estilos expresivos de las ideas que serán plasmadas en el texto; y la lectura es la función cognitiva que permite el acceso a los avances tecnológicos y científicos de la información. Da la posibilidad de recrear y comprender mejor la realidad, de ser capaz de dialogar críticamente con el texto, tomar una postura frente a ello y valorarlo integrándolo en el mundo mental propio.

Estas habilidades son fundamentales para que se de el proceso de la comunicación y se vinculan a través del dinamismo propio de la comunicación en el papel de Emisor (quien habla-escritor) y de Receptor (escucha-lector).

Para el momento en que eres el EMISOR: o sea quien habla o escribe:

*** Cuando vas a conversar con alguien de manera importante busca un lugar tranquilo, apagar los celulares y distractores para eliminar o evitar los ruidos o interferencias.

- Prepara el tema: Si vas a ser emisor de un evento en particular, debe investigar lo más que puedas sobre el evento, que objetivo tiene y que te solicitan, a qué público está 
5 Diálogos con Amor: Comunicación en Pareja

dirigido y para cuantas personas y de que características. Si es informal, saber de que tema y prepararlo, adecuado para la situación.

- Envía mensajes claros y comprensibles que permitan al receptor crear una imagen clara de lo que se está diciendo. Libres de ambigüedades y con la menor cantidad de palabras posible.

- Describe tus sentimientos: expresión verbal de manifestaciones no verbales, como cambios corporales, para aclarar el sentimiento que origina estas manifestaciones. Usar expresiones de énfasis, que en lo verbal es dar entonación y volumen al mensaje, al escribir son importantes las ayudas tipográficas.

- Sé directo es decir usa el pronombre personal en 1a persona: "yo" y usa verbos específicos y directos de la acción de lo que deseas expresar. Siguiendo la estructura lógica y coherente de la oración: Yo deseo ir al cine, ¿vamos? En lugar de decir: Oí que están pasando una película buenísima. Y luego reprochas ¿porqué no me llavaste al cine?

- Es importantísimo que seas coherente entre tu información verbal y la no verbal, o sea todas las expresiones corporales desde tus gestos, la forma en que te paras, mueves las manos, si te inclinas o alejas. Recuerda que eso dice más que tus palabras. Cuida tu tono de voz, volumen, énfasis en aspectos importantes. Se da haciendo una pausa antes, subiendo un poco el tono y hacercándote a la persona. Si estás en un escenario, muévete por él. Y muy importante ve a la persona o a todo tú público, de preferencia a la cara y en momentos especiales a los ojos.

*** Estudia estos elementos, y prepara varios temas, y realiza prácticas de cada uno de los elementos planteados. Debes enviar mensajes claros y concretos, hablar en $1 \underline{a}$ persona, usar lenguaje verbal y no verbal. Primero te grabas y observas, corriges tus errores y lo realizas encontrando a alguien que te escuche y date vuelo, y le haces preguntas y sé sensible a sus necesidades también, ve de que manera lo integras, que se sienta atendido. Maneja un tema con cada persona diferente, cuando lo hagas, escribe cómo te sentiste, qué comentarios te hace la persona al final, le puedes hacer preguntas relacionadas con cada uno de los aspectos que debías realizar. Para que tengas retroalimentación y sigas practicando y mejorando. 
Mejora tu calidad de vida y rendimiento académico a través del autoaprendizaje

Anota en tu cuaderno todas las notas de tus ejercicios, sobre que tema fue, con quién o quiénes lo expusiste, cómo te sentiste y que te dijo la o las personas. Y con todo esto tú cómo te evalúas, ¿Es coherente lo que sentiste con lo que te reportaron? Y después de todos los ejercicios ¿Sientes cambios? ¿En qué? ¿Y qué te falta hacer?.

Para cuando eres el RECEPTOR o sea quien escucha o lee:

"Lo que pretende una buena escucha es: crear un ambiente seguro, amable y acogedor donde la persona se sienta libre y pueda por si misma encontrar los caminos para integrar su pensamiento".

Para realizar este ejercicio requieres de tu cuaderno, lápiz y un lugar cómodo sin interferencias. En tu hoja vas a anotar y responder a las siguientes preguntas:

1. ¿Cuáles son mis cualidades para escuchar? Cuando alguien te habla, te platica, que haces para saber que te dice.

2. ¿Cuáles son mis defectos para escuchar? Cuando alguien te habla que otras cosas haces aparte de oir lo que te dice. ¿Oyes al inicio y te dedicas a integrar tu respuesta? ¿Estás emitiendo juicios?

Anota tus respuestas. Ahora para analizarlas debes tomar en cuenta que, tus respuestas van a depender de los filtros que tengas en el momento de la comunicación, y estos son:

- La imagen que tienes de ti mismo y la que tienes del otro.

- La definición que le das a la situación, tema o asunto que están tratando.

- Tus creencias, valores, experiencias dolorosas o gozosas, que hacen que tengas una manera particular de ver la realidad.

Estos filtros son aprendidos y como consecuencia no escuchas bien al otro. Sabiendo esto, te invito a estar consciente de tus filtros y comenzar a quitarlos lo más posible para mejorar tu habilidad de escucha. Se paciente esto no se da de la noche a la mañana, como 
5 Diálogos con Amor: Comunicación en Pareja

primer paso debes identificarlos y luego poco a poco vas teniendo más tiempo para evitar que se presenten, los puedes ver venir y por lo tanto puedes decidir detenerlos.

*** Para que los puedas manejar, haz una historia en que te inventas a ti y a la otra persona, y luego tratas de inventar una plática como las que has tenido con otras personas, pero ponla de manera que sea coherente con los filtros que has inventado; ahora prueba con otra versión y luego con otra, puedes tomar un poco de ideas de alguna novela o serie que aparezca en la tele, puedes buscar a las personas que se ven marcadamente diferentes a ti para facilitar la representación.

A continuación te voy a dar algunos ejercicios para que practiques a fin de mejorar tu habilidad de escucha:

*** Cuando vas a conversar con alguien de manera importante busca un lugar tranquilo, apagando su celular, de esta manera vas a eliminar o evitar los ruidos o interferencias.

*** Vas a tomar cada uno de los ejercicios y los vas a practicar al menos por 5 min con una persona, que sepa o que no sepa. Platica con ella, cualquier tema del momento que salga y los primeros 5 minutos, compórtate natural, como eres cotidianamente, a los cinco minutos cambias y ahora demuestras interés, marcando un poco exageradas las muestras; a los cinco min; los siguientes vas resaltar los puntos clave y resumir; los 5 siguientes vas a hacerle sentir empatía. En todos los casos vas a ser respetuoso de su turno en el uso de la palabra sin interrumpir; sin comentarios agresivos o groseros y sin comentar lo que te contó.

Demuestra interés en lo que la otra persona te está trasmitiendo, presta toda tu atención a la persona quien habla y dale claras muestras de ello: mírale frecuentemente a los ojos, asiente mediante gestos y expresiones verbales, si es posible a los ojos, sonríe, afirma con la cabeza, asintiendo con expresiones breves: jajaa!, jok! , jeso es interesante!, jeso me gusta!...

- Cuando escuches, acepta al otro como es, sin juzgar, criticar, sermonear u ofender, se coherente con tus gestos, posturas del cuerpo, miradas y expresiones de las manos pues 
Mejora tu calidad de vida y rendimiento académico a través del autoaprendizaje

estas corresponden a tus pensamientos. Olvídate de estar pensando tus respuestas, o sólo pon tus oídos abiertos, sin juicios. Mantén la congruencias entre el lenguaje verbal y no verbal

Usar Paráfrasis o retroalimentación: Expresa con tus propias palabras el contenido del mensaje recibido, repitiendo los puntos clave de aquello que te cuente y que parezca tener importancia para él, para darle a entender que le vas comprendiendo. Puedes decir: "haber, si te entendí, mencionaste que... y resumes lo más importante, o lo que tu crees que es", o si no fue muy clara le dices: "Haber ya no entendí dijiste que ... y ahora ... yo veo que esto va en diferente sentido, me puedes aclarar"; o cuando hace una pausa le dices "¿sí?" o "repites la última palabra” para que continúe.

Ponte en los zapatos del otro, con EMPATía. Siente lo que la persona te comparte como si fuera tuyo.

Vas a respetar su tiempo de hablar sin interrumpirlo salvo para mostrar que atiendes y para pedir aclaración si no entiendes algo, permítele dirigir la comunicación adecuadamente. En ningún momento puedes decir qué debe hacer o cómo les has hecho tú. Sólo que te lo solicite

No utilices expresiones agresivas como: "nunca sabes lo que dices", "ya ni te escucho por que siempre me dices lo mismo", "siempre dices tonterías".

No divulgues a otras personas lo platicado sin el consentimiento de quien te lo expresa.

***Práctica estos elementos en tus conversaciones y puedes pedirle a alguien cercano que lo haga contigo como un ejercicio, a fin de que te retroalimente y tú a él.

Reflexiona: Con respecto a lo que tus acciones están generando en tus amistades y aquellas personas con quienes te relacionas y haz cambios de manera consciente para ver su impacto.

Estos dos roles de la comunicación son muy importantes y debes esforzarte para realizarlos de la mejor manera, a fin de que tengas una comunicación eficaz y eficiente.

Para ello es necesario que realices varios ejercicios para dominarlos: busca una persona con quien puedas platicar y sugerirle practicar y le dices las reglas del juego son: y lees los 
5 Diálogos con Amor: Comunicación en Pareja

apartados de emisor y receptor, y cada 5 min agregas una instrucción adicional, es decir los primeros $5 \mathrm{~min}$. Lo hacen normal como de costumbre, a los $5 \mathrm{~min}$, toman la primera línea y así consecutivamente hasta agotarlas y cambian roles, y le preguntas ¿tu que quieres ser? Y empiezan a platicar sobre cualquier tema. Al terminar hacen comentarios de lo que vivieron en cada etapa, y rol. Y si tienen tiempo ahora pasen a la modalidad de escribir y leer, puede ser en el whats usando emoticones, para que llegue rápidamente, sin cambiar de rol hasta el final, el que lee lo hace en voz alta para que el otro sepa que lo hizo. Y luego cambio.

Anota en tu cuaderno las experiencias.

Reflexiona: Con respecto a ¿Cómo te han resultado los ejercicios? ¿Qué elementos te han funcionado mejor? Establecer estos elementos es importante para conocer mejor los roles de los participantes en la comunicación y te ayuda a tener mejores resultados.

\section{Emociones y Comunicación}

\section{La Margarita}

Realiza esta actividad de manera honesta y tratando de identificar los elementos de $u$ comunicación de pareja.

***Para realizar este ejercicio requieres de papel, lápiz y un lugar cómodo sin interferencias. En tu hoja vas a dibujar una flor siguiendo los siguientes pasos:

1. Dibuja el tallo de una margarita sin pétalos. 
Mejora tu calidad de vida y rendimiento académico a través del autoaprendizaje

a. Piensa que temas de conversación puedes hablar sin dificultad con tu pareja y ve agregando pétalos a tu margarita con el nombre cada uno de esos temas, puedes poner tantos pétalos como temas de conversación tengas.

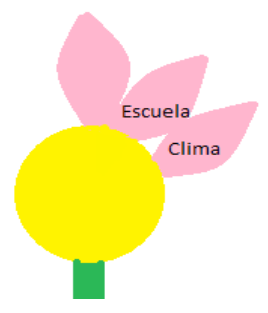

2. Una vez que ya hayas colocado todos los pétalos en tu margarita, puede que existan temas que se te dificulte hablar con tu pareja, esos temas los escribirás en otros pétalos fuera de tu margarita, como pétalos caídos.

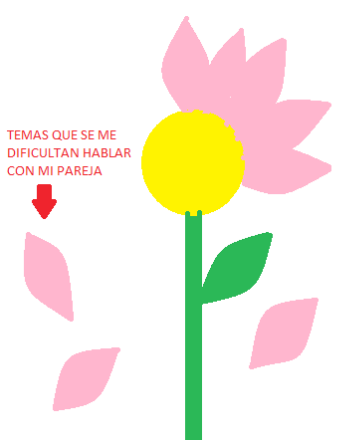

Analiza ¿En dónde tienes más pétalos en la flor o en el piso?, ¿Qué te dice esto? Qué debes preparar e investigar más temas y conversar con las personas y luego con la pareja. Piensa que tienes la dificultad o la facilidad de comunicar cierto tipo de temas, en virtud de que nos comunicamos en distintos niveles, dependiendo de confianza que tengamos con la persona a quién le estamos transmitiendo el mensaje, estos niveles son:

1. Nivel Superficial: no hay compromiso, de rol social. Usas fórmulas convencionales: "mucho gusto", "me va bien, gracias", hablas de cosas cotidianas, que no comprometen tu intimidad. 
5 Diálogos con Amor: Comunicación en Pareja

2. Nivel Medio: puedes hablar de temas un poco más profundos aunque a nivel de "lugares comunes" (ya expresas alguna opinión, alguna postura personal) Temas: ecología, política, familia, gustos, trabajo. Puedes hablar de lo que piensas, de lo que haces, pero todavía no lo que eres.

3. Nivel Profundo: te permites hablar de tu persona, de lo que eres. Esta comunicación compromete: sentimientos, valores, compromisos vitales (religiosos, políticos...) Posturas centrales ante tu vida.

***Haciendo uso de esta información, enumera los temas de tu margarita de acuerdo a los niveles de comunicación.

El objetivo de este ejercicio es que te hagas más consciente de los temas que se te facilitan o dificultan hablar con tu pareja. Y a partir de ello valores y abras la posibilidad de conversar sobre temas que quizás te cueste trabajo hablarlos, sin embargo, comunicarlos te permita lograr un mejor entendimiento con tu pareja. Nota, algunos de estos temas van tomando tiempo de maduración de la relación, con forme avanza, se van tocando temas más intimos, es importante que te des cuenta de ello y vayas dando su espacio, sin forzar las situaciones.

A continuación te voy a dar algunas prácticas para mejorar tu habilidad de habla y expresión emocional:

Escucha bien. *** Puedes grabar (con tu celular) algún programa radiofónico de noticias o mejor aún de entrevistas. Cuando lo estás grabando pones atención y en el comercial haces una síntesis de lo que respondió el entrevistado y así mientras dure la entrevista, cuando termine lo escuchas y revisas lo que escribiste y lo que dijo. Si sigues practicando puedes mejorar muchísimo en tu escucha.

$\checkmark$ Dirígete a la persona de frente, vela a los ojos. ${ }^{* *}$ a partir de ahora cuando hables con alguien, sobretodo un tema importante y los temas que hables con tu pareja lo miras a los ojos. Anota en tu cuaderno los resultados que vas teniendo.

$\checkmark$ Busca el momento adecuado para decir lo que quieres. En ocasiones, un buen estilo comunicativo, un modelo coherente o un contenido adecuado pueden irse al traste 
si no has elegido el momento adecuado para transmitirlo o entablar una relación. Es importante que cuides algunos aspectos que se refieren al momento en el que quieres establecer la comunicación:

$\checkmark$ El ambiente: el lugar, el ruido que exista, el nivel de intimidad... ***Son distractores que dificultan que te pongan atención, sobretodo si tienen la televisión o el radio encendidos, porque estos jalan poderosamente la atención, pero debes ser cuidadoso, ya que si abruptamente le apagas la TV o el radio, puedes generar enojo y tampoco será buen momento. A lo mejor tienes que decir que deseas tener una conversación especial, que si cuando termine su programa pueden apagarla. Y eso es muy distinto.

$\checkmark$ Ordena tus ideas y sentimientos antes de hablar.

$\checkmark$ Evita afirmaciones radicales como: siempre, nunca, todo, jamás o equivalentes.

$\checkmark$ Evita utilizar un lenguaje grosero, agresivo o despectivo cuando no estas de acuerdo en algo.

$\checkmark$ Dale tiempo para escuchar (sin atiborrarlo).

$\checkmark$ Percibe su reacción (si es inadecuada, vuelve a ordenar tus ideas y dale tiempo de procesar) ojo al lenguaje no verbal.

$\checkmark$ Si es adecuada la reacción (al objetivo de la comunicación) entonces el mensaje está claro.

$\checkmark$ Exprésate de una forma clara, abierta, lo que sientes piensas y deseas.

$\checkmark$ Verifica el mensaje diciendo: ¿fui claro? ¿me expliqué?, bajo ningún pretexto decir ¿me entendiste?, porque se puede sentir como que lo consideras poco inteligente.

$\checkmark$ Habla claramente y en un tono de voz moderado.

$\checkmark$ Se congruente entre lo que se piensas, sientes, dices y haces.

$\checkmark$ Si vas a criticar o pedir explicaciones debes esperar a estar a solas con tu interlocutor. *** En esos casos debes ser cuidadoso con la forma de decirlo, de manera clara y concreta, siendo respetuoso, siendo asertivo, expresando los acuerdos que se tienen y la manera en que percibes que te faltó, diciendo algo así como: "Nosotros tenemos este acuerdo, y siempre lo hemos respetado, hasta ahora que tu hiciste 'tal...' ¿Tienes algo que decir? Quiero decirte que merezco una disculpa y que te voy a pedir que esta fue la última vez que ocurrió". 
5 Diálogos con Amor: Comunicación en Pareja

$\checkmark$ Si han comenzado una discusión y ves que se te escapa de las manos o que no es el momento apropiado utiliza frases como: "si no te importa podemos seguir discutiendo esto ... más tarde".

Reflexiona: Sobre "El truco de un buen conversador no es ser interesante (saber hablar), sino estar interesado (saber escuchar). Se da una buena escucha activa cuando se es capaz de prestar atención de una forma intencionada, dando claras muestras de comprensión y generando empatía, es decir, sabiendo ponerse en el lugar del otro". ¿Estás de acuerdo? ¿Con lo que has experimentado puedes argumentar en contra de lo anterior o a favor?

\section{¿Quién soy?}

Como has visto, es importante conocerte para poder comunicarte mejor y tener un mayor dominio de las situaciones, por ello, este ejercicio te ayudará a lograrlo.*** Para realizar este ejercicio requieres papel, lápiz y un lugar cómodo sin interferencias. Vas a contestar las siguientes preguntas, estas son personales y nadie más puede ayudarte a contestarlas, ¿Estás listo?

1. $\mathrm{Mi}$ favorito(a) es:...

2. Si pudiera tener un deseo, sería:...

3. Me siento feliz cuando:...

4. Me siento triste cuando:...

5. Me siento muy importante cuando:....

6. Una pregunta que tengo sobre la vida es:....

7. Me enojo cuando:...

8. La fantasía que más me gustaría tener es:...

9. Un pensamiento que aún sigo teniendo es:...

10. Cuando me enojo, yo:...

11. Cuando me siento triste, yo:...

12. Cuando tengo miedo, yo:...

13. Me da miedo cuando:... 
Mejora tu calidad de vida y rendimiento académico a través del autoaprendizaje

14. Algo que quiero, pero que me da mido pedir, es:...

15. Me siento valiente cuando:...

16. Me sentí valiente cuando:...

17. Amo a:...

18. Me veo a mí mismo (a):...

19. Algo que hago bien es:...

20. Estoy preocupado (a):...

21. Más que nada me gustaría:...

22. Si fuera anciano (a):...

23. Si fuera niño (a):...

24. Lo mejor de ser yo es:...

25. Odio:...

26. Necesito:....

27. Deseo:...

Al terminar de contestar este cuestionario analiza sobre las respuestas que has dado a cada una y cómo te has sentido; y nota la coherencia de tus respuestas y sentimientos, cuando es mas fuerte o grande la discrepancia es que esas situaciones no son muy adecuadas para ti. Si la puedes hacer con tu pareja, intercambien sus cuestionarios y preséntense lo más detalladamente que sea posible.

Reflexiona: Con respecto a las siguientes preguntas: ¿Me fue fácil contestar el cuestionario? ¿Qué preguntas se me dificultaron contestar? ¿Me había planteado alguna vez este tipo de preguntas? Observa de qué manera te ha enriquecido este ejercicio y qué aspectos debes seguir trabajando. Cuando lo haces en pareja sirve para tener cimientos firmes para la relación, cuando se conocen, es más fuerte la relación y les sirve para resistir los malos momentos.

Alejandro Magno sostenía que "Conocerse a uno mismo es la tarea más difícil porque pone en juego directamente nuestra racionalidad, pero también nuestros miedos y pasiones. Si uno consigue conocerse a fondo a sí mismo, sabrá comprender a los demás y la realidad que lo rodea". 
5 Diálogos con Amor: Comunicación en Pareja

No le faltaba razón a este rey macedonio porque a través del autoconocimiento aprendemos a desenvolvernos con eficacia en la vida y a afrontar nuestro día a día de manera óptima. Saber realmente cómo somos, qué sentimos o qué metas queremos alcanzar son capacidades que se asocian a la inteligencia interpersonal.

Tener inteligencia interpersonal significa entender quien eres, saber identificar tus emociones y actuar en consecuencia. Habilidades que te permitirán regular tu comportamiento, resolver problemas de modo eficaz y tomar decisiones. Con el autoconocimiento aprenderás a identificar tu capacidades, pero también tus limitaciones. Esto te ayudará a planificar metas de manera realista para evitar frustraciones futuras.

\section{El que se enoja pierde}

El manejo adecuado de las emociones es fundamental para desenvolvernos de manera óptima en sociedad. Debido a que es muy desagradable relacionarnos con personas gruñonas o enojonas que pierden los estribos y gritan a la menor provocación. Por ello, es conveniente que trabajes con tus sentimientos.

***Para realizar este ejercicio requieres tu cuaderno, lápiz y un lugar cómodo sin interferencias. Anotar las oraciones al menos tres veces en desorden. Siguiéndolas instrucciones: "Te pido que completes las siguientes oraciones, con lo primero que se te venga a la mente":

a) Llego a enojarme cuando....

b) Cuando me enojo yo digo...

c) Cuando me enojo yo hago...

d) Cuando alguien se encuentra cerca de mí y estoy enojado, yo....

e) Consigo controlar mi enojo mediante...

Si terminas y sientes que tienes más versiones de respuestas, continúa anotándolas frases hasta que sientas que no hay más. Al terminar, de resolver, analiza tus respuestas y observa cuál es tu comportamiento y tus emociones. Y se crítico con estás reacciones, conocer si te 
Mejora tu calidad de vida y rendimiento académico a través del autoaprendizaje

permite analizar las situaciones en que tiendes a contestar verbal y físicamente de manera controlada o das rienda suelta a tus emociones, sin importar lo que dañes a quienes están contigo.

Reflexiona: Con respecto a que, frecuentemente el enojo saca de nosotros las cosas más negras y ofensivas, contra nosotros, los demás y hasta con el mundo. Parecería como dice el dicho "no buscas quién te lo hizo sino quien te la pague". Y para sacar el enojo haces y dices cosas muy fuertes, de las que luego te arrepientes, sin embargo, después del accidente ya nada es igual.

Esto te demuestra como estás siendo dominado (a) por la emoción negativa y eres capaz de hacer mil cosas y hay gente que hasta llega a matar. Por ello, debes aprender a controlar tus manifestaciones, si te sientes muy enojado, es decir iracundo, mejor no hables con la persona, pídele que por favor te de un tiempo fuera y que en cuanto estés mejor aclaran la situación. Lo que puedes hacer para controlarte, es correr, brincar, patear un balón, es decir desfogar esa energía y luego, hacer respiraciones profundas y analizar que fue lo que te sacó de balance y reflexionar, para que vayas recuperando tu poder.

Este ejercicio lo puedes realizar con cualquier tipo de emoción intensa que te saca de dominio (enojo, euforia, depresión, ira o vergüenza) y te ayudará a hacer conscientes las manifestaciones de tus emociones para poder controlarlas, pues es difícil controlar lo que no conocemos. Por control emocional me refiero a regular, controlar o eventualmente modificar estados anímicos y sentimientos -o su manifestación inmediata- cuando éstos son inconvenientes en una situación dada. No podemos elegir nuestras emociones. No se pueden simplemente desconectar o evitar, lo que sí está en nuestro poder conducir nuestras reacciones emocionales y con ello, nuestras acciones.

\section{Cuenta hasta 10}

El siguiente ejercicio de relajación te ayudará a tener una mejor claridad en el pensamiento y a controlar tus emociones. 
5 Diálogos con Amor: Comunicación en Pareja

Para realizar este ejercicio requieres de una pista de música relajante la cual puedes encontrar fácilmente en youtube y un lugar cómodo sin interferencias.

*** Sigue las siguientes instrucciones: Procura una posición cómoda -puede ser una silla-, manteniendo una postura recta en tu columna y apoyando tus pies sobre el piso... Coloca las palmas de tus manos hacia arriba al frente, a la altura de tu cintura, apoyándolas sobre tus piernas... Cierra por un momento los ojos y presta atención a tu respiración... Toma aire y cuenta hasta diez...; retén el aire en tu interior y cuenta otra vez hasta diez... Exhala el aire contando hasta diez... y quédate sin aire mientras cuentas hasta diez lenta y suavemente..., repítelo Toma aire y cuenta hasta diez...; retén el aire en tu interior y cuenta hasta diez.... Exhala el aire contando hasta diez... y quédate sin aire mientras cuentas hasta diez lenta y suavemente..., repítelo una vez mas, Toma aire y cuenta hasta diez...; retén el aire en tu interior y cuenta otra vez hasta diez... Exhala el aire contando hasta diez... y quédate sin aire mientras cuentas hasta diez lenta y suavemente... inhala suavemente moviendo lentamente tu cuerpo iniciando por las manos y pies, los brazos y piernas, el cuerpo, cuello y cabeza. Al terminar puedes ir abriendo poco a poco tus ojos y estirarte.

Este ejercicio lo puedes realizar cuando estés pasando por alguna situación de tensión, cuando estés experimentando alguna emoción que te impida pensar con claridad, o simplemente cuando te quieras relajar.

\section{Las 3 ERRES Resentimiento - Requerimiento - Reconocimiento}

Expresar mis sentimientos y necesidades fue la primera respuesta que di, sin embargo, no estuvo bien manejada, tal vez se dio en un momento inadecuado, y al evaluar los sentimientos negativos que tengo tras de esa primera experiencia fallida, solicite alguna atención y fui ignorado, viene una situación similar y hago algo similar, y no obtengo lo que deseo, sino que ocurre algo similar entonces me resiento, y si lo pienso lo vuelvo a resentir, y regularmente se le agrega el sentimiento de enojo, hasta que decidimos hacer algo por superarlo. Si es así mejoraremos el bienestar personal y colectivo. 
Mejora tu calidad de vida y rendimiento académico a través del autoaprendizaje

\begin{tabular}{|l|c|c|c|}
\hline \multicolumn{4}{|c|}{ Cuadro de las 3 ERRES } \\
\hline Nombres & Resentimiento & Deseos & Reconocimiento \\
\hline & & & \\
& & & \\
& & & \\
\hline
\end{tabular}

Al reverso de la hoja anotarás: "expresar mi resentimiento de una forma clara y coherente. Para realizar este ejercicio requieres de tu cuaderno, lápiz y un lugar cómodo sin interferencias.

*** Las instrucciones son las siguientes: Dobla de manera vertical cuatro veces una hoja con el fin de formar 4 columnas.

- En la primera columna anota una lista de los nombres de 10 personas con las que estés más en contacto diariamente, como son: padre/madre, novio/a, amigos/as y/o profesores/as.

- En la segunda columna, escribe 1 ó 2 enunciados que expresen un resentimiento hacia las personas señaladas en la columna anterior. Puedes utilizar expresiones del tipo: "Estoy resentida con Carlos porque no me ha pasado los apuntes. Estoy resentida con mi amiga Lucía porque no me acompaña a almorzar."

El resentimiento supone un modo de expresar un enfado hacia otras personas. Es importante que sepas escribir ese resentimiento sin caer en la ofensa personal o el insulto. Tras un resentimiento, existe un deseo o requerimiento hacia la otra persona.

- A continuación, en la tercera columna, tratarás de escribir lo que deseas realmente que hagan aquellas personas hacia las que sientes un resentimiento. Tienes que procurar ser claro y preciso; como por ejemplo: Estoy resentido con mi amiga Lucía, porque no me hace caso y requiero que me escuche pues he discutido con mis padres.

- La cuarta columna corresponde al reconocimiento.

El resentimiento y el requerimiento anterior pueden resultar más significativos para la persona hacia quien los diriges si intentas ver los aspectos positivos de su actuación y 
5 Diálogos con Amor: Comunicación en Pareja

apreciar las razones de su comportamiento. Así pues, podemos encontrar expresiones de reconocimiento como: "Reconozco que tiene mucho que estudiar y no puede atenderme como antes".

- Al reverso de la hoja o en una hoja nueva escribe en una oración completa como podrías expresar tu resentimiento de una forma clara y coherente, para cada persona anotada en tu lista inicial-. Un ejemplo de oración completa sería: "Estoy resentido con mi amiga Lucía, porque no me hace caso y requiero que me escuche pues he discutido con mis padres, sin embargo, reconozco que tiene mucho que estudiar y no puede atenderme como antes".

- Ahora procede a responder todos los elementos del ejercicio. Cuando termines revisa todos los elementos planteados para cada persona. $Y$ ve si falta o sobra algo. Especialmente si en el revés estás planteando que requieres para superar la situación y cuidando el reconocimiento.

Reflexiona: Sobre tus sentimientos y pensamientos con cada persona. Ante lo que debes considerar una estrategia asertiva (solicitar y expresar las emociones o deseos de manera clara, directa, sin pasar sobre los demás) para el control de diversas emociones tales como ira, ansiedad, celos o tristeza al permitir manifestar y comunicar positivamente tus sentimientos, empatizando con los de los demás, y ayudando a resolver conflictos de forma pacifica. Reconociendo asertivamente que tengo derecho a pedir lo que deseo, siempre y cuando entienda que el derecho del otro es decidir si acepta o declina la solicitud, sin ofenderme ni molestarme.

\section{Estrategias Constructivas para la SOlución de Conflictos en la Relación de PaReja}

¿Sabes que es un conflicto? Según su etimología latina, la palabra conflicto (con-flicto) significa "enfrentamiento con». Los conflictos se producen cuando entran en juego diferentes intereses. También de deben a la diferente percepción de la realidad que tienen las personas implicadas, a pesar de estar ante una misma situación. 
Mejora tu calidad de vida y rendimiento académico a través del autoaprendizaje

No debes temer a los conflictos, sino más bien aprender y desarrollar una serie de habilidades prácticas, afectivas y cognitivas, para saber qué puedes afirmar tu postura, aprender a amar las diferencias, cooperar en lugar de competir, y llegar a acuerdos creativos sin necesidad de crear tensiones. Aprender a escuchar el punto de vista ajeno y a expresar el propio sin imponer tu criterio por la fuerza ni tampoco someter a otros ni dejarte avasallar.

Ten en cuenta también que un conflicto no resuelto te seguirá afectando durante un largo periodo de tiempo hasta que lo resuelvas. Cuando se nos presenta un conflicto tendemos a buscar pronto una solución y nos invade una gran inquietud mientras lo conseguimos. La mayoría de los conflictos tienen una solución satisfactoria para todas las personas, que nos hace progresar y aprender sobre nosotros mismos. Las situaciones conflictivas suelen ayudarnos a aclarar nuestras ideas y nuestro camino en la vida, ayudan a definir la identidad de las personas implicadas, estimulan la creatividad, generan nuevos vínculos y compromisos personales, forjan relaciones nuevas y constructivas.

Hay diferentes estrategias para resolver los conflictos:

\section{1.- Persuación}

Para persuadir trata de: Conseguir mediante razones que una persona piense de una manera determinada o que haga cierta cosa: lo persuadieron para que los acompañaseuno ejerce el control de las decisiones.

- Ser firme, sin agresión.

- Evita ceder por afecto o consideración hacia el otro, mejor negociar, a veces cede él y otras tú.

- Defender tus intereses con fundamentos sólidos

- Explicitar las consecuencias de resignar tus intereses, frecuentemente.

\section{2.- Concesión}

Para conceder trata de: 
5 Diálogos con Amor: Comunicación en Pareja

- Dar el consentimiento a una persona que tiene poder autoridad.

- Cooperar sin esperar nada a cambio.

- Renunciar de buen grado.

- Reconocer al otro sus aspiraciones.

\section{3.- Ensamble (Acuerdo mutuo)}

Para ensamblar trata de:

- Inventar opciones con la otra parte.

- Preguntar "¿qué tal si...?"

- Mantenerte flexible ante cualquier idea nueva.

- Escuchar y aprender del otro.

- Evitar posturas en beneficio propio que no beneficien a la otra parte.

- Lo sano es negociar para balancear, y de esta manera los dos ganan.

*** Con alguna persona de confianza invítala a realizar el ejercicio, haciendo cambio de roles, es decir uno lo ejercita cada una de las estrategias de solución de problemas para que valoren los dos lados de cada una y valoren la elegida. Anoten cada estrategia empleada como se sintieron y que ventajas observaron. Analicen los resultados cuales fueron los beneficios o avances de cada estrategia.

Reflexión: Reflexiona las veces que has actuado de manera persuasiva, de concesión o de ensamble. Analiza que paso, qué hiciste y cómo te sentiste y al final cómo se resolvieron las situaciones, en cada una, ¿quién ganaba en cada caso?

\section{Amor e Intimidad en Pareja}

Desde el punto de vista de la Psicología, se habla de la relación amorosa como un proceso social en donde factores como el compromiso y la intimidad son necesarios para el amor maduro, con los que se pueda establecer una relación de pareja. 
Mejora tu calidad de vida y rendimiento académico a través del autoaprendizaje

La relación de pareja es quizás la experiencia más gratificante en la que se ve envuelto el ser humano, razón por la cual, ha sido objeto de la atención del hombre desde tiempos muy antiguos. La experiencia amorosa se encuentra en todas las culturas (Jankowiak y Fisher, 1992) y es sin duda una de las situaciones más estimulantes en nuestras vidas, así Sternberg $(1986,1989)$ establece tres bases fundamentales del amor: intimidad, pasión y compromiso.

En los matrimonios más sólidos, cuyo objetivo es compartir una profunda sensación de trascendencia, respaldando las esperanzas y aspiraciones de su pareja y dan sentido a la vida en común, honrando y respetando al otro. Así, los miembros de la pareja comparten una profunda sensación de trascendencia. La mayoría de las disputas vienen de conflictos más profundos, como diferencias de personalidad, valores o estilo de vida; por ello, lo que necesitas es entender las diferencias, para aprender a vivir con ellas, honrándose y respetándose uno al otro. Y sobre todo, crear los mapas del amor de la pareja, dado que entre más comprendas y conozcas a tu pareja, más fácil les resultara seguir conectados y resolver los problemas que les presenta la vida (Gottman y Nan, 2004).

*** Lo que deben hacer es reconocer lo que saben uno del otro, y fortalecer ese conocimiento a través de toda la información es confidencial entre los miembros de la pareja, no la critique ni intentes dar ninguna recomendación.

Para ello, de la siguiente lista selecciones, 10 preguntas, responde, y si es posible tu pareja también, si no está has lo tuyo, para ver qué tanto conoces a tu pareja. Este conocimiento es muy importante, en virtud de que entre más se conocen más solida es su relación y se fortalece.

Cuando terminen de responder asignen puntaje: si la respuesta fue correcta se le dan los puntos que indica la pregunta y uno para ti, si fue error, ninguno recibe puntos. $Y$ pueden seguir jugando las veces que deseen o sientan que necesitan, para profundizar en el conocimiento mutuo. Hasta que logren los puntajes más altos. 
5 Diálogos con Amor: Comunicación en Pareja

Repitan el ejercicio, con otras 10 y así hasta terminar, y reconociendo que se pueden agregar frases o bien, modificarlas. Pueden realizarlo en una o varias sesiones; si lo realizas en varias sesiones emplea el tiempo para reflexionar sobre lo planteado y a la siguiente sesión se pueden preguntar y aclarar las dudas.

Preguntas:

1. Nombra dos de mis mejores amigos (2)

2. ¿Cuál es mi grupo musical favorito? (2)

3. ¿Qué ropa llevaba cuando nos conocimos? (2)

4. Nombra una de mis aficiones (3)

5. ¿Dónde nací? (1)

6. ¿A qué tensiones me enfrento actualmente? (4)

7. ¿Describe con detalle lo que he hecho hoy, o ayer? (4)

8. ¿Cuándo es mi cumpleaños? (1)

9. ¿Cuándo es nuestro aniversario? (1)

10. ¿Quién es mi pariente favorito? (2)

11. ¿Cuál es mi mejor sueño no realizado? (5)

12. ¿Cuál es mi flor favorita? (2)

13. ¿Nombra uno de mis mayores miedos? (3)

14. ¿Cuál es mi hora del día favorita? ( )

15. ¿Qué me hace sentir más competente?(4)

16. ¿Qué me excita sexualmente?(3)

17. ¿Cuál es mi plato favorito? (1)

18. ¿Cómo prefiero pasar una tarde? (2)

19. ¿Cuál es mi color favorito? (1)

20. ¿En qué quiero mejorar personalmente? (4)

21. ¿Qué regalos me gustan más? (2)

22. Nombra una de mis experiencias de infancia (2)

23. ¿Donde prefiero ir de vacaciones? (2)

24. ¿Cómo prefiero que me tranquilicen? (4)

25. ¿Quién es mi mayor fuente de apoyo aparte de ti? (3) 
Mejora tu calidad de vida y rendimiento académico a través del autoaprendizaje

26. ¿Cuál es mi deporte favorito? (2)

27. ¿Qué es lo que más me gusta hacer en mi tiempo libre? (2)

28. Nombra una de mis actividades favoritas de los fines de semana? (2)

29. ¿Cuál es mi lugar preferido para una escapada? (3)

30. ¿Cuál es mi película favorita? (2)

31. Nombra alguno de los sucesos que están ocurriendo en mi vida. ¿Cómo me siento con respecto a él? (4)

32. Nombra alguna de mis formas favoritas de ejercicio (2)

33. ¿Quién era mi mejor amigo de la infancia? (3)

34. Nombra una de mis revistas favoritas (2)

35. Nombra uno de mis mayores rivales o enemigos (3)

36. ¿Cuál sería para mi el trabajo ideal? (4)

37. ¿Qué me da miedo? (4)

38. ¿Cuál es el pariente que menos me gusta? (3)

39. ¿Cómo son mis vacaciones favoritas? (2)

40. ¿Qué clase de libros me gusta leer? (3)

41. ¿Cuál es mi programa favorito de televisión? (2)

42. ¿Qué lado de la cama prefiero? (2)

43. ¿Qué me pone triste? (4)

44. Nombra una de mis preocupaciones (4)

45. ¿Qué problemas médicos me preocupan? (2)

46. ¿Cuál fue el momento en que pasé más vergüenza? (3)

47. ¿Cuál fue la peor experiencia de mi infancia? (3)

48. Nombra dos de las personas que más admiro (4)

49. Nombra a mi mayor rival o enemigo (3)

50. ¿De todas las personas que los dos conocemos quién me cae peor? (3)

51. Nombra uno de mis postres favoritos (2)

52. Nombra una de mis novelas favoritas (2)

53. ¿Cuál es mi restaurante favorito? (2)

54. Nombra dos de mis aspiraciones, esperanzas o deseos (4)

55. Tengo alguna aspiración secreta, ¿Cuál es? (4) 
5 Diálogos con Amor: Comunicación en Pareja

56. ¿Qué platos aborrezco? (2)

57. ¿Cuál es mi animal favorito? (2)

58. ¿Cuál es mi canción favorita? (2)

59. ¿Cuál es mi equipo deportivo favorito? (2)

*** Ya que lo respondas, intercambia con tu pareja y revísenlo o estúdienlo y pregúntense sobre alguna duda.

Reflexiona: Sobre la importancia del conocimiento de tu pareja. Analiza ¿Qué tanto te ha servido conocer y clarificar tus dudas de ella, para tu relación de pareja? ¿Cómo crees que esto favorece su relación, que has visto al respecto? Gottman y Silver (2004) han encontrado que el centrarte y trabajar esto, te ayuda a mejorar tu relación si aumentas y mejoras tu conocimiento. Reconociendo personajes, actitudes, valores, actividades en nuestra vida de pareja:

\section{Creación del Mapa de Amor de la Relación de Pareja}

Uno de los regalos más valiosos que pueden hacerse al compañero es la sensación de que es conocido y comprendido. Conocerse el uno al otro no debería ser una tarea: conocerse es amarse.

*** Ya que has revisado el conocimiento de la pareja, ahora es tiempo de crear el Mapa del Amor de la Pareja y la manera en que este les permite sentirse más unidos, considerando rubros como:

Amigos.

Amigos potenciales.

Rivales, competidores y/o enemigos.

Eventos importantes en la vida de mi pareja.

Filosofía de vida, (los aspectos más significativos).

Eventos inminentes.

Que esperamos con ilusión. 
Mejora tu calidad de vida y rendimiento académico a través del autoaprendizaje

Que esperamos con temor.

Actuales tensiones.

Actuales preocupaciones.

Actuales aspiraciones:

para mí.

para mi pareja.

para nuestra relación.

para nuestros hijos, amigos y/o familiares.

nuestras preferencias en.

nuestros hobbies son:

Deportes.

Diversiones.

Comidas.

Música.

Autos.

Libros.

Revistas.

Ropa.

Colores.

Tiempo libre.

Artistas.

Películas.

Viajes.

*** Continuando con el conocimiento de la pareja, así como su fortalecimiento después de terminar el mapa del Amor. Ahora trabajarás sobre la manera en que podrás cultivar el cariño, respeto y la admiración con tu pareja: plantea que vas a hacer para cultivarlos. La admiración es la clave de los amores que duran, debes ponerla en marcha. La ADMIRACIÓN es una necesidad biológica que se hace más patente en la fase de enamoramiento de una pareja. Es el sentimiento que nace del reconocimiento del otro como un ser diferente a nosotros y sobre quien centramos toda nuestra atención. Admiramos lo extraño y 
5 Diálogos con Amor: Comunicación en Pareja

lo diferente. En la primera fase de enamoramiento, exageramos las virtudes del otro y obviamos sus defectos. $Y$ ello forma parte de todo un mecanismo biológico que nos permite emparejarnos y dar continuidad a nuestra especie. Por ello, en el enamoramiento se ve al otro de manera exaltada, todo es precioso, hasta sus más grandes defectos son percibidos y transformados hasta de manera graciosa, todo tiene un sabor a gloria, a dulce y a miel. Sin embargo cuando pasa el enamoramiento, todo lo ves como errores enormes, como montañas que los separan y afean el panorama.

Para que la pareja sobreviva y fortalezca su amor, es decir pase del enamoramiento al amor verdadero, es necesario que sientas la admiración, respeto y cariño, por tu pareja como persona, por lo que hace y dice y por la forma en que atiende y resuelve las situaciones. La admiración es vista como necesidad biológica, a fin de entender ¿Por qué nos impresiona tanto una persona en especial? Por la química de enamoramiento. Y, más allá de la fase inicial, ¿se puede mantener este estado de embelesamiento? Sí, se puede y, además es importante que exista un sentimiento de admiración intensa hacia el otro que garantice la supervivencia de la relación. Para cultivar este sentimiento es importante poner en práctica las siguientes acciones:

- Renuncia a la falsa modestia, cuando tu pareja te reconoce un mérito, acéptalo, sin quitarle importancia. Si haces uso de la falsa modestia, enseñas al otro a restarles valor a tus logros. En todo caso, agradece el reconocimiento que el otro te manifiesta y siéntete merecedor de su elogio.

- Crea tu propio espacio, aduéñate de tu propio espacio más allá del espacio común de la pareja. Siéntete feliz disfrutando del tiempo que te dedicas a ti mismo, a tus hobbies y a tus propias amistades. De esta forma, tu pareja te verá como un ser diferente a él, especial y autónomo.

- Reconoce lo positivo de tu pareja, por la educación que hemos tenido, acostumbramos obviar lo bueno y poner la lente de aumento en lo negativo, que ocurre entonces lo bueno disminuye y lo negativo aumenta en virtud de que lo estimulamos en demasía. Por ello, cuando el conflicto surge en la relación, nos empeñamos en descubrir los aspectos negativos de nuestra pareja. Ello hace que la admiración caiga en picada. Para 
Mejora tu calidad de vida y rendimiento académico a través del autoaprendizaje

evitar esto es necesario resaltar lo positivo del otro y evitar caer en la trampa de las desvalorizaciones.

Así vemos la importancia del elogio dentro de la relación, para reconocer las atenciones y actitudes favorables y positivas para la convivencia diaria de la pareja, que hacen que lo vivas y te sientas grandioso, espectacular o padrísimo. Agradece todo lo que el otro hace por ti o por ambos. Esto implica dar detalles concretos de alguna acción que tu pareja haya hecho a favor de su relación. Pregúntate: ¿Qué ha hecho mi pareja hoy que me haya hecho sentir bien? Identifícalo, aprécialo y comunícaselo con todo detalle. De esta forma, enseñas al otro a que haga lo mismo contigo, fomentándose así la admiración mutua.

Esto mismo debes aplicarlo a las relaciones sexuales, en las que es excelente indicarle a la pareja qué es lo que te gustan y las cosas que no te gustan e incluso aquellas que te disgustan. Aquí también debes de expresarle gratitud por la entrega que tuvo en esa intimidad. Que tiene que ver con el cariño mostrado, las caricias y los besos, así como las palabras y hechos que te llevan a sentirte amado.

\section{Fuentes de la Admiración}

De acuerdo con Saavedra (s/f) las tres fuentes de la Admiración son:

1.- Misterio.- Se trata de añadir suspenso a tu relación. Para ello juega un poco con la cercanía y la lejanía, sin mostrarte siempre tan disponible para tu pareja. Ello aumentará la tensión romántica entre ustedes.

*** Inscríbete en algún curso, que te requiera tomarte tiempo para ti y hacer cosas nuevas y divertidas, en las que la pareja no esté incluida. Pueden se clases de Tai-Chi, Chi-Kung, baile o yoga. Cosas divertidas que te ayudan a crecer y abres un mundo diferente que te nutre incluso emocionalmente, ya que tienes nuevas amistades. O puede ser de tu especialidad.

2.- Novedad.- Es necesario que hagan cosas nuevas juntos. Las experiencias novedosas son emocionantes y favorecen los sentimientos de admiración y atracción. Cualquier actividad 
5 Diálogos con Amor: Comunicación en Pareja

que resulte poco habitual puede ser válida, desde probar un nuevo restaurante, comprar entradas en el último instante para ir a algún espectáculo, decidir en el último momento del día ir a dormir a un hotel o nadar después del anochecer. Engalana tu vida de pareja con aventuras y novedades. La novedad es, junto con el misterio, todo un afrodisíaco natural.

Inicia actividades nuevas en tu vida pueden ser caminatas, entrar a un club de cine, en que encuentres películas lindas para inquietar a la pareja como la de "Bailemos" https://www. youtu be.com/watch?v =XbuyS-_SSjM

3.- Autoaprecio.- Una fuente importante de admiración es el autoaprecio. Si no te aprecias a ti mismo, tu pareja tampoco te valorará y admirará. Todos pasamos por altibajos, unas veces estamos más negativos o más cansados y, otras veces nos sentimos más positivos y capaces. Lo que has de intentar es no hacer depender tu autoaprecio de tu estado de ánimo. Una cualidad relacionada con el autoaprecio y que promueve la admiración es el afán de superación. Una persona capaz de asumir nuevos retos despierta admiración. Tu pareja te admirará aún más si eres una persona que está en constante evolución, que no alguien que lleva una vida anodina. Ello además fortalecerá tu autoaprecio.

\section{Aprender De La Historia}

La mejor prueba es la forma como recuerdan el pasado. Cuando los buenos recuerdos quedan distorsionados, es una señal de que el matrimonio necesita ayuda.

Una visión fundamentalmente positiva de la pareja y el matrimonio es un arma muy poderosa cuando llegan los malos tiempos.

*** Escribe en tu libreta la historia de tu relación, iniciando con el primer día que viste o conociste a tu pareja, y con detalle describe qué fue lo que más te gustó e ilusionó. Y así continúa con la descripción de su historia. Si te es posible pídele lo mismo a tu pareja, léanlas y coméntenlas. Esto les ayuda a encontrar la manera de enderezar el rumbo perdido. La mayoría de las parejas, al recordar juntos su pasado, sienten que su actual relación de renueva. 
Mejora tu calidad de vida y rendimiento académico a través del autoaprendizaje

*** Recupera el hábito de pensar positivamente sobre tu pareja cuando están separados; como repetirte frases todo el día respecto a alguna cualidad o hecho positivo que hace tu pareja en el presente o que ha hecho alguna vez.

El Respeto, actitud que reconoce y aprecia el valor y la dignidad de los demás y les trata de acuerdo con ese valor. El cariño y la admiración son antídotos contra el desprecio. Si mantienes una sensación de respeto, es menos probable que muestres disgusto cuando discuten.

A menudo, con el tiempo, los cónyuges pierden de vista su cariño y admiración. Si estos están despareciendo, el camino para recuperarlos comienza siempre por darnos cuenta de su valor para nosotros y nuestra vida.

*** Lee con atención: UNA PEQUEÑA HISTORIA. Érase una vez... un chico con mal carácter. Siempre hay alguno asi, de esos que siempre están quejándose, gritando, protestando y recriminando a los demás su comportamiento cuando a él no le gusta. A veces golpean, y casi siempre humillan a los otros, lo cual duele más que una bofetada. Su padre le dio un saco de clavos y le dijo que clavara uno en la verja del jardín cada vez que perdiera la paciencia y se enfadara con alguien. Él lo pensó bien y vio que su padre tenía razón. Tenía que cambiar. El primer día clavó 37 clavos. Durante las semanas siguientes se concentró en controlarse y día a día disminuyó la cantidad de clavos nuevos en la verja. Había descubierto que era más fácil controlarse que clavar clavos. Finalmente llegó un día en el que ya no clavaba ningún nuevo clavo. Entonces fue a ver a su padre para explicárselo. Su padre le dijo entonces que era el momento de quitar un clavo por cada día que no perdiera la paciencia. Los días pasaron y finalmente el chico pudo decir a su padre que había quitado todos los clavos de la verja. El padre condujo a su hijo hasta la verja y le dijo: «-Hijo mío, te has comportado muy bien, pero mira todos los agujeros que han quedado en la verja. Ya nunca será como antes. Cuando discutes con alguien y le dices cualquier cosa ofensiva le dejas una herida como ésta. Puedes clavar una navaja a un hombre y después retirarla, pero siempre quedará la herida. A pesar de las veces que le pidas perdón -y debes hacerlo siempre-, la marca de la herida permanecerá. Una herida provocada con 
5 Diálogos con Amor: Comunicación en Pareja

la palabra hace tanto daño como una herida física». Y por eso también es importante saber olvidar las ofensas que se nos hicieron. Pero olvidarlas de verdad, para no volver a utilizarlas nunca como reproche cuando nos volvamos a sentir ofendidos. Porque entonces las heridas vuelven a abrirse. Los amigos son joyas raras de encontrar. Están listos para escucharte cuando tienes necesidad. Te sostienen y te abren su corazón. Cuídalos. Enseña a tus amigos cómo les quieres... y les respetas. Evita humillarles y quedar tú por encima. Respétalos siempre, aunque no debas darles la razón cuando están en el error. Discrepa sin herir. Son personas, como tú. Piensa a menudo cómo te sentirías tú en su lugar. Yobra en consecuencia. Pero no se trata sólo de los amigos... Hay más gente en el mundo, a la que le afecta, para bien o para mal, lo que hacemos y decimos. Hay una regla de oro, un principio moral básico que sirve para actuar con respeto: TRATA A LOS DEMÁS SÓLO COMO DESEAS SER TRATADO. Es en realidad una forma de decir: Respeta, respeta, respeta... Trata a los demás como personas (Respeto, $s / f$ ).

*** Reflexiona con las ocasiones en que has perdido el control y has incurrido en hacer lesiones como clavos a tus seres queridos y en especial en este momento piensa en tu pareja. Bien reconocerlo es el primer paso, ahora que vas a hacer para hablar con tu pareja y ofrecerle disculpas y el compromiso de que por ningún motivo vas a cometer esos mismos errores. Y de qué manera ofreces enmendar el daño causado, que puede ser hacer algo que a tu pareja le guste tener, o hacer.

Recuerda que las relaciones son vivas y dinámicas, van modificándose y cambiando, por ello, las debes nutrir con tus buenos actos y aplicando los elementos que has practicado en la presente guía, así como en las demás del texto.

iiiTe deseo que tengas éxito en el fortalecimiento de tu relación!!! 



\title{
Tus ideas ¿a tu favor o en tu contra?
}

\author{
Adrián Barragán Rangel
}

os pensamientos, sentimientos y conductas actúan de forma integrada en el individuo, Ly la perturbación emocional proviene, no de los hechos en sí, sino de la evaluación que hacemos de esos hechos, según los estamos percibiendo (Ellis, 1962). Por lo tanto, si ocurre algo que no nos gusta y lo evaluamos como malo (cognición o pensamiento), nos sentiremos mal al respecto, ya sea enojados, o tristes (sentimientos) y haremos algo al respecto, llorar o evitar la situación (conducta). La mayor parte de nuestro sufrimiento viene de nuestra manera de pensar y sentir respecto del mundo y de los demás. Ya que nosotros somos quienes creamos nuestros propios sentimientos.

La asertividad es la capacidad de autoafirmar los propios derechos, sin dejarse manipular ni manipular a los demás. Los comportamientos asertivos suponen un saber defender las propias necesidades frente a las exigencias de los demás sin llegar a utilizar comportamientos agresivos o violentos. La asertividad es el punto medio entre los comportamientos inhibidos propios de las personas tímidas o inseguras y los comportamientos violentos propios de las personas agresivas y egoístas.

Ellis define las creencias o pensamientos racionales como cogniciones evaluativas de significado personal que son de carácter preferencial que se expresan en forma de deseo, preferencia, gusto, agrado y desagrado, que generan emociones y comportamientos adecuados. Los pensamientos irracionales son cogniciones evaluativas de carácter absolutista y dogmático (debería/tendría) y generan emociones negativas perturbadoras que interfieren en la consecución de metas que proporcionan felicidad. El propósito es enseñar a la persona a prestarle atención a sus ideas y pensamientos, para que a partir de ese aprendizaje, pueda hacer posible el cambio. Centrándose en resaltar la importancia 
Mejora tu calidad de vida y rendimiento académico a través del autoaprendizaje

de cuatro formas de pensamiento irracional: demandas o exigencias, catastrofismos, baja tolerancias a la frustración, depreciación o condena global de la valía humana (Ellis y Abrahams, 1978).

\section{Contenido Temático}

1. Descubrimiento tus pensamiento

2. Aprendiendo el Modelo ABC

3. Ideas irracionales y emociones desagradables

4. Aprendiendo a modificar la irracionalidad

Objetivo: Que al final de esta guía aprendas a identificar pensamientos negativos y a modificarlos, para con esto evitar o disminuir tu malestar emocional por medio del manejo de tus pensamientos racionales y una comunicarse asertiva con los demás.

Actividad 1. Persona, Animal o Cosa. Piensa un momento sobre la posibilidad de cambiar de identidad y que te permitas ser otra persona, animal, tu héroe favorito o cosa. ¿Qué persona, animal o cosa serías?

Reflexión: ¿Qué elegiste ser? analiza qué elegiste y los motivos por los qué elegiste esa opción ¿Qué ventajas tiene ser esa opción que elegiste? ¿Y cómo te sientes? Escribe una reflexión de las preguntas.

Date cuenta de que al cambiar de identidad crees que te permite hacer otras cosas y te hace sentir mejor, sin embargo esto está señalándote que hay cosas de tu persona o vida que no te satisfacen ¿qué pasa desde tu propia identidad?, estás inconforme, ¿qué deseas cambiar? Date cuenta que esta es una salida falsa, ya que no es verdadera y la mejor opción es que trabajes, seguro que por eso estás siguiendo esta guía, aquí vas a ir cambiando muchas cosas que no te gustan, el cambio que logres será real y seguirá contigo después de que termines de trabajar, y si no fuera, sería porque regresaste a viejos estilos de funcionamiento, pero regresas a trabajar y lo recuperas en cuantas veces lo necesites, así como el trabajo con las otras guías te ayuda para que te sientas más a gusto contigo mismo. 
6 Tus ideas ¿a tu favor o en tu contra?

Actividad 2. La Frase Incompleta. De esta serie de frases que están incompletas, lo que harás es simplemente completarlas con lo primero que se te venga a la mente, y vete rapidito, se honesto, sólo tú lo leerás, si así lo deseas, las frases son las siguientes:

1. Tengo miedo de...

2. Lo que más me hace enojar es...

3. Lo que más me pone triste es...

4. Tengo miedo de...

5. Lo que más me hace enojar es...

6. Lo que más me pone triste es...

7. Tengo miedo de...

8. Lo que más me hace enojar es...

9. Lo que más me pone triste es...

10.Tengo miedo de...

11.Lo que más me hace enojar es...

12.Lo que más me pone triste es...

13.Tengo miedo de...

14.Lo que más me hace enojar es...

15.Lo que más me pone triste es...

Una vez que hayas terminado analiza tus respuestas, en virtud de que si te dejaste fluir y realmente anotaste lo primero que vino a tu mente, te permitirán conocer por dónde andan tus necesidades o áreas de oportunidad para trabajar con ellas.

Reflexiona: ¿Por qué esto que puse me da miedo, o me enoja o que entristece? Tan solo de pensarlo, regresa esa emoción como si lo estuvieras experimentando, es importante que te des cuenta de cómo activas tus emociones con tan solo recordar las cosas, anota esas emociones identificadas con diferentes situaciones, para trabajarlas en otro momento cuando realices tu jerarquía y en el debate de la irracionalidad. Recuerda que dice la frase "recordar es volver a vivir" y es lo que hacemos con nuestros pensamientos, dicen que los humanos somos la especie que vive mil veces la misma experiencia y lo que es peor, las mil 
Mejora tu calidad de vida y rendimiento académico a través del autoaprendizaje

nos perturbamos. Así que, vas avanzando en conocer y experimentar la manera en que te perturbas, es muy importante, eso te da una mayor motivación para salir de esa forma de perturbación, a través de transformar la irracionalidad.

\section{Actividad 3. Aprender de las Experiencias.}

Es importante que estés en un lugar privado, para evitar interrupciones, si hay alguien por ahí, diles que tienes que hacer una tarea y que por favor no te interrumpan. Vas a necesitar realizar una grabación, por ello coloca el celular de manera que quede fijo y quedé enfrente de ti cuando hables y narres tu historia. Siéntate con una postura cómoda y relajada, cierra tus ojos y busca en tu memoria, en tus recuerdos una situación bastante desagradable que hayas vivido y que sientas que te sigue moviendo emocionalmente. Con tus ojos cerrados recuérdala lo más vívidamente posible y cuando la tengas bien clara, suavemente abre tus ojos y enciende la grabación.

Te sentarás enfrente del celular y vas a hablar como si estuvieras contándole a tu mejor amigo y le vas a explicar la situación desagradable que viviste, sin tapujos, estás en confianza total. Hasta que termines, si sale enojo, exprésalo, o la emoción que se te venga, sólo sin darle rienda suelta, sin permitir que se desborde y termines hasta con el celular.

Al terminar, realiza tres respiraciones profundas, brinca un poco y sacude la emoción, para que estés en condiciones de pensar, entonces vas a observar la grabación: siéntate enfrente de la proyección, escúchala sin comentarios ni críticas, sólo expresando tu comprensión y observa tus expresiones al momento de narrar tu experiencia.

Una vez que hayas terminado, expresa cuáles fueron las expresiones que hiciste y que significado tenían? ¿Era congruente con lo que expresabas verbalmente o se te estaba revelando, quizás algo que no querías decir? Al finalizar, vas a decir ¿Qué piensas del suceso? y ¿Qué emociones percibiste en ti? y si crees que están relacionadas con el evento que describiste o si tus emociones estaban desmedidas para la situación. Anota las respuestas y ve de qué manera esto te ayuda a analizar lo que viviste. 
6 Tus ideas ¿a tu favor o en tu contra?

Repite si deseas la parte de escuchar, como si le pasara a tu mejor amigo o amiga, y luego como responderías las preguntas, considerando que es para alguien más. Anota las respuestas y ve de qué manera esto te ayuda a analizar lo que viviste.

Reflexiona: Posteriormente compara tus comentarios y los que hiciste para otra persona $y$, ve las diferencias, y considera que cuando es para otra persona le respondes desde la distancia emocional y tal vez tú seas un poco más objetivo, ya que estás interesado en crecer emocionalmente. Piensa en cómo te sentiste cuando expresaste tu situación y si fuiste muy honesto cuando lo hiciste ante la cámara. ¿Qué aprendiste y sacaste de este ejercicio? Realiza unas notas para seguirlas trabajando más adelante

\section{Actividad 4. Historia de Mis Recuerdos.}

Vas a trabajar en un lugar confortable y privado, si hay personas cerca avísales que estarás realizando una tarea y que por favor no te interrumpan. Empieza por ponerte cómodo y traer al presente la historia de un recuerdo importante de tu vida. Trata de conectar con esta historia como si estuviera pasando justo ahora, vívela como entonces, sin frenarla, incluso expresa las emociones que están viniendo a tu mente, responde las interrogantes de ¿Qué sentimientos te provoco recordar la historia? ¿Por qué crees que hayas experimentado esos y no otros? ¿Qué te decías en ese momento o en este momento, o tal vez en cada momento? Esto propicia la apertura de tus propias experiencias, permítete revivir tanto las cosas agradables como las desagradables, conócete y adéntrate a tus sensaciones y emociones. Una vez que termina la vivencia, escribe en una hoja todo lo que recuerdes, ¿Qué ocurrió? ¿Qué te decías o pensabas tú mismo? ¿Qué sentimientos presentaste, todos? ¿Cómo te sentías y actuabas, qué hiciste? ¿ildentificas qué pasó después?

Reflexiona: Como ya te has dado cuenta los recuerdos son como un trozo de tu pasado y los guardas como verdaderos tesoros Con ellos te acuerdas de momentos felices de tu vida. Cada vez que vienen a tu mente las personas y los hechos vivimos de nuevo la experiencia en que participaste. Al comentar un recuerdo, revelas algo de ti mismos, de tu historia personal. Con todo lo que has obtenido, tienes un material importante para corregir tu forma de pensar y por lo tanto de sentir y de actuar. Con la información obtenida 
Mejora tu calidad de vida y rendimiento académico a través del autoaprendizaje

puedes trabajar con la identificación de tu ABC y realizar las adecuaciones pertinentes de tus Bs creencias o pensamientos y con ello estas arreglando tu motor. Felicidades estás cambiando por un motor último modelo.

Actividad 5. Gimnasia Cerebral. A continuación te pido que leas la actividad completa antes de hacer el ejercicio: Ponte de pie, con los pies separados y los brazos extendidos hacia los lados. Ya que estas en esa posición cierra los ojos y sin abrirlos levanta el pie que más utilizas y trata de colocarlo sobre la rodilla contraria para formar la figura de un 4, Inhala profundamente y exhalar lentamente mientras llevas una cuenta regresiva del número 20 al número 1 y mueve los brazos hacia delante. Ya que lo tengas, baja el pie y los brazos y sin abrir los ojos, repetirás el ejercicio con el pie contrario.

Reflexiona: Como ya te diste cuenta esto te ayuda a aclarar la mente y aliviar la fatiga mental, ya que al ponerte en esa posición estás haciendo que la sangre circule mejor al cerebro y con esto se oxigene, practícalo cada vez que te sientas cansado mentalmente

\section{Actividad 6. Identificar Acciones Concretas para Enfrentar Situaciones Problemáticas.}

Graba las instrucciones dejando tiempo para que puedas realizar las actividades y ponte en una posición cómoda:

Pon la grabación, cierra los ojos e imagina y localiza en un momento de éxito, en el que hayas actuado de manera adecuada que te permitió alcanzar tus objetivos (pausa) Tomate tu tiempo. Ya que la tengas, comienza a visualizarla y centra tu atención en ella, observa cual fue la forma en que se dio, revisa el tono de voz (pausa), tus gestos (pausa), los argumentos que usaste tanto verbales como no verbales (pausa), de qué naturaleza fue el evento, cuantas personas implicaba (pausa). Lo que es más importante, ¿qué objetivo perseguías? (pausa) Ahora, aísla mentalmente los elementos fundamentales del comportamiento que asumiste en esa situación y trata de representarte, en su escenario mental, esos rasgos de comportamiento y cuáles eran tus pensamientos (pausa). Pon atención a la forma en qué te veías (pausa). Ahora observa qué te decías a ti mismo, cuál era tu tono de voz, qué escuchabas del entorno (pausa). Y finalmente siente qué sentías, a 
qué te sabía el momento, que percibías de tu postura corporal (pausa). Permítete sentir tu comportamiento. Aprende a reconocer lo que tu cuerpo te dice (pausa). Ahora, deja que la imagen del éxito de tu propósito, se adueñe de la escena ante tus ojos (deja pasar una pausa prolongada).

Ahora, poco a poco regresando aquí, en este momento, respirando hondo y estirando tu cuerpo, empezando con las manos y pies, luego brazos y piernas y el tronco, cuello y cabeza, para después abrir los ojos.

Reflexiona: Te diste cuenta de muchas más cosas de una sola situación, dándote cuenta cómo estás interactuando con las demás personas, te ayuda a detectar los elementos positivos y negativos de la interacción y de cómo debes trabajar para tener relaciones más sanas y lograr el bienestar propio y contribuir al de los demás. Y piensa que de esta manera puedes trabajar para tener más éxito en las cosas que te propones, esto te ayuda a reconocer que tienes los elementos para salir adelante en lo que te propones, y ahora lo que intuyo que te propones es tener bienestar a partir de superar los pensamientos distorsionados que te perturban, para ello, en esta guía vas a continuar trabajando con ellos.

\section{Actividad 7. Llevando el Registro de Pensamientos Automáticos.}

Los pensamientos automáticos, también llamados ferrocarril: son aquellos que pasan de manera imperceptible, sin darte cuenta, los aprendiste desde muy pequeño y te los repites a cada instante y por ello, son invisibles y vienen comprimidos, como una aspirina, tienen muchos componentes, se presentan como respuestas ante situaciones que te impactan y ante las que sientes que las emociones te pegan y si te pregunto qué pensaste dirás nada sólo me "enojé", "asusté". Lo que debes hacer para identificarlos es cuando ocurre una situación en la que sientes que una emoción te invade, en cuanto te sea posible, piensa: "¿qué pensé? y escucha", a veces son frases negativas que la gente mayor te decía de niño, por decir algo "inútil, implica estúpido, bueno para nada, fracasado, nunca puedes hacer algo bien y..." cualquier cantidad de palabras relacionadas con el fracaso o cometer un error. La palabra clave o activadora puede ser cualquiera como "cielito", aparentemente es positiva, pero fue asociada con una entonación que representaba reproche. 
Mejora tu calidad de vida y rendimiento académico a través del autoaprendizaje

Anota en un registro de acontecimientos (cuadro No. 1), el tipo de pensamientos que te ha sucedido, deberás practicarlo durante varios días, al menos 7. Para eso vas a realizar este registro en la tabla siguiente, escribes los encabezados y en blanco las columnas que Ilenarás con todo lo que te ocurra durante siete días y te lleve a un estado emocional diferente e intenso, positivo y negativo.

\begin{tabular}{|c|l|l|l|l|l|}
\hline \multicolumn{5}{|c|}{ Cuadro No. 1. Registro de Acontecimientos de pensamientos Automáticos } \\
\hline \multicolumn{1}{|c|}{ Día } & Hora & $\begin{array}{l}\text { Aconteci- } \\
\text { miento }\end{array}$ & Pensamiento & Emoción (0-100) & \multicolumn{1}{c|}{ Conducta } \\
\hline $\begin{array}{l}\text { Coloca la } \\
\text { fecha en } \\
\text { qué ocurrió } \\
\text { el evento }\end{array}$ & $\begin{array}{l}\text { Pon la } \\
\text { hora } \\
\text { en } \\
\text { qué } \\
\text { pasó }\end{array}$ & $\begin{array}{l}\text { Describe } \\
\text { la } \\
\text { situación } \\
\text { o evento } \\
\text { en que } \\
\text { actuaste }\end{array}$ & $\begin{array}{l}\text { Anota } \\
\text { todos los } \\
\text { pensamientos } \\
\text { que tuviste }\end{array}$ & $\begin{array}{l}\text { Escribe la emoción } \\
\text { que experimentas } \\
\text { Yla intensidad } \\
\text { de esa emoción } \\
\text { dándole un valor } \\
\text { de 0 (nada) a 100 } \\
\text { (la emoción más } \\
\text { intensa de mi vida) }\end{array}$ & $\begin{array}{l}\text { Registra aquí las } \\
\text { conductas que } \\
\text { realizaste y una } \\
\text { evaluación de si } \\
\text { fue acertada o } \\
\text { errónea. Con base } \\
\text { a si lograste lo que } \\
\text { esperabas }\end{array}$ \\
\hline septiembre & $10: 35$ & $\begin{array}{l}\text { Al } \\
\text { pararme } \\
\text { enfrente } \\
\text { del } \\
\text { grupo, } \\
\text { se me } \\
\text { olvido } \\
\text { todo }\end{array}$ & $\begin{array}{l}\text { Soy tonto, } \\
\text { hice el } \\
\text { ridículo } \\
\text { olvido todo }\end{array}$ & $\begin{array}{l}\text { Ansioso 100 } \\
\text { Enojado 90 } \\
\text { Temor de hacer el } \\
\text { ridículo 100 }\end{array}$ & $\begin{array}{l}\text { Me quedé en } \\
\text { blanco y realice } \\
\text { balbuceos, } \\
\text { temblaba, dije } \\
\text { varias estupideces. } \\
\text { Abandoné el } \\
\text { aula, diciendo } \\
\text { maldiciones y } \\
\text { azotando la puerta. } \\
\text { Saque una } \\
\text { calificación } \\
\text { reprobatoria en } \\
\text { este desempeño. } \\
\text { Que bajo } \\
\text { sustancialmente mi } \\
\text { calificación final y } \\
\text { promedio }\end{array}$ \\
\hline
\end{tabular}


6 Tus ideas ¿a tu favor o en tu contra?

A terminar los días de registro dale una revisada y analiza la relación entre los pensamientos identificados, las emociones, así mismo, relaciónalo con tus conductas. Como te has sentido con el registro ya te diste cuenta que para cambiar un pensamiento, primero hay que conocerlo.

Para aprender a parar al ferrocarril antes de que te atropelle y quitarle poder a esa palabra clave, hay palabras que tan solo oírlas te inducen a un estado emotivo y por supuesto casi siempre negativo, esa palabra puede ser tu acontecimiento, si te la dijeron o la oíste y te conectó con la emoción.

Reflexiona: Una vez que hayas tomado consciencia de la relación entre el grado de credibilidad de los pensamientos negativos y la intensidad de emociones negativas donde ya lo piensas en automático y lo haces más consciente.

\section{Actividad 8. Aprender el Modelo del ABC}

A- Evento Activante: Es el que da origen o desencadena los pensamientos y emociones. Pueden se eventos físicos o pensamientos, imágenes, recuerdos u olores. Ese conjunto de materiales lo archivas en tu memoria por si se vuelve a repetir la situación. No todos los antecedentes que existen en tu memoria son tus experiencias. Hay experiencias que otros te cuentan, las que observaste en otros y las que viviste.

B- Believes ('en inglés') Creencia, pensamientos Burradas (Heman, 2010) \{'burradas siempre y cuando sean irracionales' $\}$ : Las creencias son la interpretación que das a los hechos a través de tus pensamientos, pero la creencias son pensamientos más solidificados, repetidos largo tiempo y a veces por herencia cultural. Como cuando vas caminando por un lugar y tus amigos se callan súbitamente, ¿qué es lo que piensas? Hablaban de mí. ¿Por qué piensas eso? Seguramente lo has vivido o te han dicho que eso pasa. ¿Esto es correcto? No, pudieron callar porque se acabó el tema o simplemente podía ser un tema privado personal.

C- Consecuencias: Las consecuencias se refieren a cómo reaccionas emocional y las acciones o conductas que realizaste ante todo lo ocurrido. 
Mejora tu calidad de vida y rendimiento académico a través del autoaprendizaje

Ahora, después de haber revisado en que consiste el $A B C$ elige una situación lo más sencillo que recuerdes y practícala. Identifica en el evento más claro y completo de tu día de ayer. Traza el formato en tu cuaderno y desarróllalo (Cuadro No. 2).

Te presento dos reacciones de la misma situación con creencias diferentes y obviamente consecuencias diferentes:

\begin{tabular}{|c|c|c|}
\hline \multicolumn{3}{|c|}{ Cuadro No. 2. Modelo del ABC } \\
\hline A & B & C \\
\hline $\begin{array}{l}\text { EVENTO } \\
\text { ACTIVANTE }\end{array}$ & CREENCIAS & $\begin{array}{c}\text { CONSECUENCIAS Emotivo- } \\
\text { Conductuales }\end{array}$ \\
\hline $\begin{array}{l}\text { Lo despiden } \\
\text { de su trabajo }\end{array}$ & $\begin{array}{l}\text { Es injusto lo que han hecho conmigo, no } \\
\text { lo soporto, no tienen ningún derecho en } \\
\text { hacerlo, son despreciables y merecen lo } \\
\text { peor, les voy a partir el queso. } \\
\text { Claro como no soy su consentido. } \\
\text { Yo hago mi trabajo bien y lo entrego } \\
\text { a tiempo, no tenían motivos para } \\
\text { despedirme, llego puntual. }\end{array}$ & $\begin{array}{l}\text { C. emocional: se muestra } \\
\text { agresivo, tiene más conflictos y } \\
\text { enojo, ira. } \\
\text { C. conductual: Va al escritorio } \\
\text { del jefe y le tira sus cosas, rompe } \\
\text { todo lo que tenía de su trabajo. } \\
\text { Incluyendo papeles importantes. }\end{array}$ \\
\hline $\begin{array}{l}\text { Lo despiden } \\
\text { de su trabajo }\end{array}$ & $\begin{array}{l}\text { Es triste lo que me ha pasado y no } \\
\text { me gusta pero no es el fin del mundo, } \\
\text { además puedo aprovechar el tiempo } \\
\text { ahora para hacer aquellas cosas que me } \\
\text { gusten. } \\
\text { He tomado nuevos cursos y estoy } \\
\text { preparado para hacer algo mejor. } \\
\text { Prepararé mi curriculum, y lo enviaré } \\
\text { al call center. Yo conozco gente que ha } \\
\text { mejorado. } \\
\text { Yo hago mi trabajo bien y lo entrego } \\
\text { a tiempo, no tenían motivos para } \\
\text { despedirme, llego puntual, solicitaré que } \\
\text { me den una carta de recomendación. }\end{array}$ & $\begin{array}{l}\text { Emocionalmente: se siente triste, } \\
\text { por dejar todo lo que significaba } \\
\text { ese trabajo, compañeros. } \\
\text { Un poco angustiado por los } \\
\text { pagos que tiene que hacer, } \\
\text { aunque tiene su liquidación y } \\
\text { con eso sobrevivirá. } \\
\text { Excitado ante las posibilidades } \\
\text { de invertir en lo que le encanta. } \\
\text { Conductualmente: estar más } \\
\text { activo y buscando alternativas, } \\
\text { investigando. }\end{array}$ \\
\hline
\end{tabular}


Reflexiona: Como te has dado cuenta esto ayudar a las personas a encontrar nuevos pensamientos alternativos y más constructivos que le ayuden a sentirse mejor, a estar mejor y a conseguir sus objetivos y metas personales, que en una palabra es tener mayor bienestar y salud psicológica. Evidentemente, para conseguir este cambio de pensamiento de una manera profunda y duradera uno deberá trabajar y practicar con tenacidad hasta conseguir alcanzarlo. No hay cambio que sea fácil y mágico.

\section{Actividad 9. Las Ideas Irracionales Básicas y Elementos para Debatirlas.}

Estas son las algunas de las ideas irracionales originales de Ellis (1995), que te pueden causar conflicto o problemas al momento de realizar alguna actividad, ¿alguna coincide con lo que has llegado a pensar? Revísalas una por una y marca aquellas con las que estés de acuerdo:

1) Los humanos adultos tienen la imperiosa necesidad de ser amados y aprobados por cualquier persona significativa y relevante de su vida. Debate: es falso muchas personas pueden vivir bien y felices sin la aprobación de todos en todo momento.

2) Uno debe ser absolutamente competente y eficaz para poderse considerar útily válido. O de lo contrario, uno es una persona inadecuada e inservible. Debate: es una alta demanda que genera ansiedad y tensión y frecuentemente te bloquea para lograr tus metas, y en la vida hay muchas personas que son muy buenas en algo y son efectivas, como humanas, a veces cometen un error, pero trabajan para superarlo y lo logran.

3) Hay un cierto tipo de gente indeseable y despreciable que debería ser severamente castigada. Debate: no somos moneditas de oro para caerle bien a todos, así mismo hay diferencias culturales en dónde lo que para unos es bueno, bonito y normal, no lo es para todos, así que es un supuesto falso. Hay gente que puedes decir es nada atractiva, pero es muy amado porque tiene buen corazón.

4) Es terrible y catastrófico que las cosas no sucedan como a uno le gustaría. Debate: Ups, es una altísima demanda sin fundamento, porque es a su vez contradictoria en virtud de que el universo no se puede arreglar a los caprichos contradictorios de cada persona. $Y$ aunque no nos gusten algunas cosas, podemos vivir bien con ellas. $Y$ frecuentemente tras superar situaciones difíciles nos fortalecemos, o hacemos resilientes. 
Mejora tu calidad de vida y rendimiento académico a través del autoaprendizaje

5) Las personas deben absolutamente actuar honradamente y considerablemente y, si no hacen, son unos villanos condenables. La gente es sus actos malos. El humanismo plantea que las personas son buenas y valiosas por si mismas, que sus hechos son los cuestionables y erróneos, que son sancionados para correcciones. Y el considerar que las cosas deben ser de una manera específica está manifestando una alta demanda o exigencia, que difícilmente se puede realizar, lo adecuado es tener preferencias, que si no se realizan nos entristecen pero seguimos tranquilamente adelante y cuando es una exigencia nos sentimos altamente traicionados si no se realiza y nos sentiríamos muy defraudados.

6) La desgracia humana se origina por causas externas y que la gente no tiene ninguna posibilidad de controlarlas. Debate: la mayoría de las situaciones con que nos encontramos tienen que ver con nuestra responsabilidad, por actuar de cierta manera, así que tenemos la posibilidad de cambiar si las consecuencias no nos gustan, cambiamos nuestro comportamiento y vamos mejorando.

7) Si algo puede llegar a ser peligroso o terrible uno debe estar muy preocupado y deberá estar pensando constantemente en la posibilidad de que esto ocurra. Debate: Si algo te preocupa, lo que se recomienda es analiza la situación, de manera puntual, piensa que puedes hacer y pon manos a la obra para cambiar las cosas, que se pueden cambiar, y eso te ayuda a sentir que tienes control y a dejar de angustiarte, que sólo te hace sentir mal y te enferma.

8) Es más fácil evitar que afrontar ciertas responsabilidades y dificultades en la vida. Debate: son muy pocas cosas las que se pueden evitar, y a veces las dejas y te vas y cuando te das cuenta ya estás ahí o ellas están allá, si no solucionas el problema lo estás repitiendo y temes que se vuelva a presentar. Lo mejor es enfrentarlo y superarlo, a veces vemos los problemas enormes, y entre más les tememos más crece, si los enfrentamos, normalmente es ver paso a paso que podemos hacer y empezamos a trabajarlo y cuando sentimos ya se terminó.

9) Se debe depender de los demás y que se necesita a alguien más fuerte en quien confiar. Debate: es absolutamente falso, dependes cuando eres bebé, sin embargo conforme el niño va creciendo va aprendiendo a hacer las cosas por sí mismo y está listo, aunque los papas a veces no lo sueltan y entonces dicen que necesitas a los demás para todo. 
Vivimos en sociedad y está bien tener compañía y compartir muchas actividades y es más sano si compartes con diferentes personas, padres, hermanos, amigos, compañeros, novio, maestros....sin embargo, si no tienes compañía puedes estar bien.

10) Uno deberá sentirse muy preocupado por los problemas y las perturbaciones de los demás. Debate: falso, uno nunca debe preocuparse por los problemas, ni por los propios, lo que debe hacer es ocuparse de atender lo que puede hacer para solucionar sus problemas y por los de los demás, puede platicar con ellos, y ofrecer ayuda en lo que pueda y lo demás lo debe dejar a sus dueños.

11) Existe invariablemente una solución precisa y correcta para los problemas y que es terrible si uno no da con esa solución maravillosa. Debate: nuevamente esto es falso no hay respuestas de específicas, sólo para los exámenes, pero en la vida tenemos muchas opciones de respuesta que al ir a solucionar los problemas debemos abrir el abanico de posibilidades y analizar cada una de ellas, con pros y contras y tomar aquellas decisión que tiene mejor efectividad y menos efectos secundarios o adversos. Y a veces conviene dejar otra u otras por si la 1a opción no resulta, tenemos plan B.

12) Lo que me ocurrió en el pasado seguirá afectándome siempre. Debate: mientras no solucionas un problema este se puede repetir, pero si tú resuelves los problemas del pasado, estos se terminan y te dan lugar a otras experiencias en tu vida.

Ya te diste cuenta que todas son ideas irracionales y para evitar las consecuencias negativas hay que cambiarlas por opciones racionales, pero desde dentro de nosotros, no de dientes para afuera, porque a veces la gente cambia las palabras, pero no el sentido y dice algo que aparentemente es racional, pero se siente como irracional, así que hay que trabajar con conciencia para cambiarlo. Analiza las creencias que has marcado empieza a analizarlas y te darás cuenta que son ideas irracionales como las otras. Continúa observándote y aunque las conozcas no difícil dejar de caer en ellas, pero si te das cuenta en el instante se pueden empezar a parar.

Reflexiona: Las ideas irracionales son pensamientos erráticos te llevan a emociones y conductas negativas e inapropiadas que te provocan problemas en la convivencia. Pero sabes que eso está en tus manos, tú puedes cambiar tu pensamiento con las estrategias vistas. 
Actividad 10. ¿Cuántas Distorsiones Existen y en qué Consisten? Las distorsiones cognitivas son esquemas equivocados de interpretar los hechos, que generan múltiples consecuencias negativas. Revísalas y trata de poner ejemplos de tu vida diaria. Algunos ejemplos son pensamientos del tipo: "nadie me quiere", "todo me va mal", "el mundo es injusto", "No voy a aprobar", "piensan que soy tonto/a", "se ríen de mí", "para ser feliz debo tener dinero", "si no hago lo que dicen los demás, no les caeré bien", "ella me hace enfadar", "siempre ha sido así", "no le gusto". Aquí encontrarás una guía para hacer tu lista (Cuadro 3).

\begin{tabular}{|c|l|}
\hline \multicolumn{2}{|c|}{ CUADRO NO. 3 QUE PRESENTA LAS DISTORSIONES DEL PENSAMIENTO } \\
\hline Tipo de Distorsión & \multicolumn{1}{c|}{ Expresión } \\
\hline Inferencia arbitraria & $\begin{array}{l}\text { Llegar a una conclusión sin evidencias o incluso con evidencias } \\
\text { contrarias. Se subdivide en dos tipos: Adivinación del futuro } \rightarrow \\
\text { Anticipación sin evidencia de algún acontecimiento futuro. } \\
\text { Lectura de mente } \rightarrow \text { Conclusión sobre lo que piensa el interlocutor } \\
\text { (la otra persona) y a la que llegamos sin evidencia. }\end{array}$ \\
\hline $\begin{array}{c}\text { Abstracción selectiva } \\
\text { (filtro mental) }\end{array}$ & $\begin{array}{l}\text { Valoración de un hecho o experiencia a partir de un solo elemento } \\
\text { ignorando los otros. Enfocarse en sólo ciertos aspectos de la } \\
\text { situación, normalmente negativos. }\end{array}$ \\
\hline $\begin{array}{c}\text { Generalización } \\
\text { gencesiva (sobre- }\end{array}$ & $\begin{array}{l}\text { Conclusión extraída de uno o más hechos aislados y que es utilizada } \\
\text { como regla general para situaciones relacionadas y similares pero } \\
\text { también para otras que no lo están. Es decir sacar conclusiones } \\
\text { generales para todo, en base a un caso aislado }\end{array}$ \\
\hline $\begin{array}{c}\text { Magnificación y } \\
\text { minimización }\end{array}$ & $\begin{array}{l}\text { Incrementar la magnitud (sobreestimar) de los sucesos negativos y } \\
\text { minimizar (subestimar) la de los positivos. Algunos autores incluyen } \\
\text { dos: subtipos Catastrofización o visión catastrófica } \rightarrow \text { Imaginar } \\
\text { y especular el peor resultado posible independientemente de su } \\
\text { probabilidad de ocurrencia. O calificar la situación como intolerable } \\
\text { e insoportable cuando en realidad no lo es tanto. } \\
\text { Negación } \rightarrow \text { Tendencia a negar problemas, errores o debilidades (Lo } \\
\text { opuesto a la catastrofización). }\end{array}$ \\
\hline Personalización & $\begin{array}{l}\text { Atribución personal de sucesos externos sin base suficiente. Asumir } \\
\text { que uno mismo u otros han causado cosas directamente. }\end{array}$ \\
\hline
\end{tabular}


6 Tus ideas ¿a tu favor o en tu contra?

\begin{tabular}{|c|l|}
\hline \multicolumn{2}{|c|}{ CUADRo No. 3 QUE PRESENTA LAS DISTORSIONES DEL PENSAMIENTO } \\
\hline Tipo de Distorsión & \multicolumn{1}{c|}{ Expresión } \\
\hline $\begin{array}{c}\text { Pensamiento } \\
\text { absolutista, } \\
\text { polarizado o } \\
\text { dicotómico } \\
\text { (todo o nada) }\end{array}$ & $\begin{array}{l}\text { Interpretar los sucesos y personas en términos absolutos sin tener } \\
\text { en cuenta puntos intermedios, aparecen palabras como "siempre...", } \\
\text { "nunca...", "todo...", "nada...". Clasificar el mundo en términos } \\
\text { de blanco o negro, malo o bueno, adscribiéndose las categorías } \\
\text { negativas en la descripción de sí mismo. }\end{array}$ \\
\hline $\begin{array}{c}\text { Razonamiento } \\
\text { emocional }\end{array}$ & $\begin{array}{l}\text { Formular argumentos basados en cómo nos sentimos y no en } \\
\text { la realidad. Guiar las creencias de la realidad en función de las } \\
\text { emociones negativas sentidas. }\end{array}$ \\
\hline $\begin{array}{c}\text { Descalificar u olvidar } \\
\text { lo positivo (invalidar } \\
\text { lo positivo) }\end{array}$ & $\begin{array}{l}\text { Consiste en despreciar arbitrariamente y de forma continuada las } \\
\text { experiencias positivas. Rechazar lo positivo, considerarlo como } \\
\text { normal y común. }\end{array}$ \\
\hline $\begin{array}{c}\text { Deberías- Los Demás } \\
\text { El Mundo }\end{array}$ & $\begin{array}{l}\text { Aplicar de forma rígida las reglas sobre nuestras obligaciones, las de } \\
\text { los demás y del Mundo. Centrarse en lo que uno piensa que debería } \\
\text { ser en lugar de lo que es y aplicar reglas rígidas con independencia } \\
\text { del contexto. }\end{array}$ \\
\hline Etiquetado & $\begin{array}{l}\text { Utilizar etiquetas para describir las conductas y las personas. Las } \\
\text { etiquetas suelen ser absolutas, negativas e inalterables. }\end{array}$ \\
\hline Culpabilización & $\begin{array}{l}\text { Valoración a posteriori de un acontecimiento para establecer lo que } \\
\text { uno debería haber hecho. Culpabilizar a los demás o a sí mismo de } \\
\text { los problemas (aún sin asociación objetiva). }\end{array}$ \\
\hline
\end{tabular}

Ahora revisa las ideas irracionales o problemáticas que has identificado en los ejercicios anteriores y analizalas, para que identifiques cuál es su principal distorsión. Si no tienes suficiente material, durante tres días ve anotando todas las distorsiones de pensamiento que tienes. $Y$ los que identificas en las personas con quienes convives. $Y$ busca la manera de cambiar tus distorsiones.

Reflexiona: Ya observaste que hay veces que hacemos uso de estas distorsiones y no nos damos cuenta, ya has identificado las tuyas y eso te permite ir haciendo cambios en tus pensamientos. Mantente perseverante en tu trabajo, tienes muchos años pensando como 
Mejora tu calidad de vida y rendimiento académico a través del autoaprendizaje

lo estabas haciendo así que debes avanzar, pero no se da de la noche a la mañana, trabaja con cada uno que te caches de aquí en adelante, lo transformas en pensamiento racional.

\section{Actividad 11. Modificando Mis Ideas en Racionales.}

Dobla una hoja de papel a la mitad y del lado izquierdo escribe un formato como el cuadro 4 , unos casos de ideas irracionales que has identificado en los ejercicios anteriores, o de tu vida cotidiana las cuales ya revisaste anteriormente, como ejemplo: "él/ella debería de saber lo que me gusta" Del lado derecho tratarás de modificar esas ideas para que sean racionales. Es decir, que convertirás esa frase en algo libre de exigencia y con la forma en que trabajarás para resolver el conflicto, como: "a mí me gustaría que él/ella supiera lo que me gusta, se lo diré".

\begin{tabular}{|c|c|}
\hline \multicolumn{2}{|c|}{ Cuadro 4. Para Transformar las Ideas Irracionales en Racionales } \\
\hline $\begin{array}{c}\text { Ideas Irracionales o pensamientos } \\
\text { automáticos }\end{array}$ & $\begin{array}{c}\text { Ideas Racionales } \\
\text { (transformadas) }\end{array}$ \\
\hline "él/ella debería de saber lo que me gusta". & $\begin{array}{c}\text { "a mí me gustaría que él/ella supiera lo que me } \\
\text { gusta", se lo diré. }\end{array}$ \\
\hline & \\
\hline
\end{tabular}

Reflexiona: Ya te diste cuenta de la importancia de poder cambiar las ideas irracionales por ideas racionales. Esto te permitirá tener mejores relaciones y te sentirás cada vez mejor.

Actividad 12: Aprendiendo a cambiar los pensamientos negativos. Vas a usar de nuevo tu libreta pero con un nuevo esquema que es el siguiente y no caigas en la trampa de echar la culpa de tus males a los demás, si no que reconoces en ti, en tus pensamientos distorsionados la clave de tus males emocionales, estás en condiciones de sustituirlos por pensamientos más racionales, realistas, objetivos y lógicos. Para ello, usa el cuadro No. 5 que aquí tienes: 
Cuadro No. 5. Para el Reconocimiento de los Diferentes estilos de Perturbaciones del Pensamiento

PRIMER PASO: DESCRIBE EL ACONTECIMIENTO QUE TE OCUPA:

SEGUNDO PASO: ANOTA TUS EMOCIONES NEGATIVAS (rabia, pena, ansiedad, desánimo, apatía, temor, ira, odio, euforia sostenida, periodos maniaco-depresivos, furia, enojo, depresión, agresión, entre otras), y puntúa cada uno de ellos de 0 (nada) a 100 (máximo).

TERCER PASO: TÉCNICA DE LAS TRES COLUMNAS

\begin{tabular}{|l|l|l|}
\hline Pensamientos automáticos & \multicolumn{1}{|c|}{ Distorsiones } & \multicolumn{1}{|c|}{ Respuestas racionales } \\
\hline $\begin{array}{l}\text { Anota tus pensamientos } \\
\text { negativos y calcula el nivel } \\
\text { en que posees cada uno } \\
(0-100)\end{array}$ & $\begin{array}{l}\text { Identifica las distorsiones de cada } \\
\text { pensamiento automático }\end{array}$ & $\begin{array}{l}\text { Sustitúyelos por } \\
\text { pensamientos más } \\
\text { realistas y el nivel en que } \\
\text { posees cada uno (0-100) }\end{array}$ \\
\hline & & \\
\hline
\end{tabular}

CUARTO PASO: RESULTADOS. Evalúa nuevamente el nivel en que posees cada pensamiento automático de 0 a 100 y señala la casilla que describe cómo te sientes en este momento.

Reflexiona: Después de que lo escribas pregúntate ¿podría pensar alguna enseñanza de ese recuerdo? ¿Se puede cambiar y sacar algo bueno de estas experiencias?

Como ya te diste cuenta estas experiencias te ayudan a resolver otros eventos en situaciones similares. Y a superar cosas de atrás para que ya se vayan y no reaparezcan.

Actividad 13. Me da Pena. Con el objetivo de superar las situaciones que sentimos amenazantes.

Imagina la situación más ridícula y embarazosa que se te haya ocurrido y prepara un texto describiéndola lo más detalladamente posible. Léela frente al espejo. 
Mejora tu calidad de vida y rendimiento académico a través del autoaprendizaje

¿Qué sentimientos y emociones experimentaste en ese momento? ¿Qué puedes aprender de esta experiencia? Trata de imaginar ¿cuáles fueron los pensamientos que tuviste en ese momento y cuáles los que te llegaron ahora que lo reviviste? No podrías actuar diferente porque tus emociones te estaban gobernando, activadas por los pensamientos automáticos, esta es la clave, si quieres cambiar tus acciones debes cambiar tus pensamientos y 10 debes identificarlos. Ahora imagina qué podrías haber pensado en ese momento de una manera racional. Ahora repite la actividad cambiando los pensamientos por pensamientos racionales, observa ¿cuáles son tus emociones al cambiar tus pensamientos?

Reflexiona: con respecto a la importancia que tiene el reconocer que si uno no tenía información no podía comportarse de manera racional, dado que la sociedad genera como herencia de educación la tendencia a pensar de manera distorsionada, incluso hay varios dichos populares que lo sostienen son creencias canonizadas, así que ahora te toca a ti decidir cambiar, ser racional y alcanzar el bienestar, y luego tú puedes cambiar la historia para tu prole y heredarles una forma de pensar racional y positiva.

Actividad 14. Actuado la Superación de la Vergüenza. Con el objetivo de ejercitar una forma diferente de actuar ante situaciones de vergüenza.

Haz al menos tres actividades que normalmente no haces, siempre reconociendo tus pensamientos irracionales, tratando de debatirlos y planteando los racionales, cuidando las relaciones con las personas involucradas, siempre deberás ser educado, solicitando las cosas por favor y agradeciendo las atenciones recibidas, algunas cosas podrían ser: Mantén la atención del dependiente con preguntas y comentarios; Pruébate mucha ropa o calzado y sin comprar nada; Titubea frente al vendedor una y otra vez a la hora de decidirte por algún artículo; Genera conversación de tipo más personal ("Wow la pasé súper, el desayuno fue espléndido y la compañía no veas..."); Pregunta por un artículo raro; Ojea artículos de manera minuciosa y lenta y sal sin comprar nada; Pide que te muestren cómo funciona un aparato y agradeces la demostración y te despides. 
Luego realiza tu lista de las cosas que más pena te dan, cuidando que sean cosas permitidas en ese contexto, jerarquízalas y empieza a trabajar con cada una de ellas, buscando la manera de superarlas y luego actuándolas, en orden inverso, primero las que te generan menos pena y luego las que te generan más pena. $Y$ ve anotando cómo te sentiste al hacerlo. Si te pega duro busca volver a hacerlo.

Si es muy fuerte y no lo puedes realizar, hazlo de manera imaginativa, realiza una relajación suave, en un lugar cómodo y privado, y cierra tus ojos y visualiza como si estuvieras realizando la acción, si es tan fuerte que no lo aguantas, imagina a un amigo o amiga realizándolo, y luego lo realizas tu como si fueras él o ella y luego siendo tú y cuando lo logres en la imaginación, entonces lo podrás realizar en la vida real.

Reflexiona: Trata de imaginar cómo hubiera sido si hubieras reaccionado de una manera diferente, y que hubieras pensado en ese momento de ti de una manera racional. Repite el ejercicio en diferentes lugares hasta que logres pensar racional sin sentirte incómodo, eso sí, siendo educado y agradeciendo las atenciones del personal.

Estos ejercicios de vencer la vergüenza, tienen una base fundamental en las relaciones asertivas, en las cuales las personas actúan de tres posibles maneras: asertiva, agresiva y sumisa o tímida. Las relaciones asertivas son las deseables, en virtud de que establecen una relación óptima con las personas, con un trato educado y justo, respetando los derechos propios y los de los demás, en el cual se busca el bienestar de todos. Las relaciones agresivas, están basadas en una situación o demanda egoísta, en la que lo único que les importa a estas personas son sus deseos, y exigen que todos les den lo que desean, son personas con baja tolerancia a la frustración y su deseo es egoísta, sólo importa él. Y en las relaciones sumisas, se someten a las personas agresivas y con tal de sentir que alguien las necesita, las valora, aunque las pesquen de trapeador, ellas, no sienten tener derechos, y permiten que alguien agresivo los someta a sus caprichos, se preocupan porque loe otros estén bien, ellos no importan, les gusta servir. Y hasta que puedas tomar clara consciencia de cómo interviene la interpretación de los acontecimientos no asertivos en la generación de tus diferentes estados emocionales. Los acontecimientos no asertivos pueden ser 
Mejora tu calidad de vida y rendimiento académico a través del autoaprendizaje

externos como conflictos con los demás, que incluyen, la pareja, la familia o los amigos en los diferentes ámbitos o también eventos internos del tipo recuerdos negativos del pasado o imágenes preocupantes de acontecimientos venideros. Cuando empiezas a trabajar para ser racional, y te responsabilizas de lo que haces, identificas los factores internos, que tú puedes ejercer y con ello tienes mayor control de las emociones y de las relaciones que estableces.

Actividad 15. Mi Recuerdo Irracional más Terrible de la Escuela. A continuación (cuadro 6) revisarás las emociones negativas y sus pensamientos importantes que en ocasiones te impiden ejecutar actividades de manera adecuada, como son frustración, enojo, apatía, en el siguiente formato visualiza y apunta situaciones terribles en las que te sentiste más frustrado, apático, enojado en la primaria, secundaria y prepa. Así mismo, identifica todos los pensamientos de cada situación.

\begin{tabular}{|l|l|}
\hline \multicolumn{2}{|c|}{ Cuadro No. 6. MI RECUERDO IRRACIONAL MÁS TERRIBLE DE LA ESCUELA } \\
\hline Mi recuerdo más terrible de la primaria & \\
\hline Mi recuerdo más terrible de la secundaria & \\
\hline Mi recuerdo más terrible de la Preparatoria & \\
\hline Mi recuerdo más terrible de la licenciatura... & \\
\hline $\begin{array}{l}\text { Mi recuerdo más terrible de... situación } \\
\text { actual }\end{array}$ & \\
\hline
\end{tabular}

Después de que lo escribas revisa tus respuestas. Con lo visto en las emociones irracionales, para ver a que ideas se relaciona y cuáles son los tipos de distorsiones de los pensamientos y situaciones de cada etapa de tu desarrollo.

Reflexiona: ¿Podrías pensar desde ese recuerdo algún aprendizaje?, ¿Qué aprendiste con ese evento? ¿Cómo podrías haber manejado la situación para vencer la frustración? acerca 


\section{Tus ideas ¿a tu favor o en tu contra?}

de esto, ¿’Puedes y sacar algo bueno de estas experiencias? Puedes decir de qué manera el manejo de tus pensamientos te ayudaría a responder las interrogantes.

\section{Actividad 16. Veinte Cosas que Me Encanta Hacer.}

Ahora realiza una lista con veinte cosas que te encante hacer en tu vida, jerarquízalas, al margen el número por el nivel de importancia. Asignando el numero 1 al más importante y 20 al de menor interés.

Después de hacer la lista, contesta las siguientes preguntas:

A) ¿Aprecio lo que hago y hago lo que aprecio?

B) ¿Lo afirmó en público cuándo hay oportunidad de hacerlo?

C) ¿Lo elegí entre varias alternativas?

D) ¿Lo elegí después de considerar y aceptar las consecuencias?

E) ¿Lo elegí libremente?

F) ¿Mi conducta está de acuerdo con lo que pienso y digo?

$\mathrm{G})$ ¿Mis patrones de conducta son constantes y repetidos?

H) ¿Cómo te sientes después de ver tus intereses más claros y evaluar las consecuencias y la razón de cada uno?

Reflexiona: Es importante clarificar lo importante en tu vida y cómo repercute el hecho de hacer lo que te gusta en tu comportamiento y tus pensamientos. Así que de tarea te queda seguirte describiendo y descubriendo lo que te gusta y encontrar tiempo para hacer lo que te apasiona. Así como seguir trabajando con tus pensamientos irracionales para fortalecer tu racionalidad y asertividad.

Actividad 17: La esquela Para la siguiente actividad necesitaras una hoja de papel y un lápiz, a continuación tendrás que escribir tu propia esquela, eres libre de escribirla en la forma que prefieras, completando los espacios vacíos que están en el texto de abajo. 


\section{HOJA DE TRABAJO “LA ESQUELA”}

murió de ayer a la edad de

Era miembro de

Le sobreviven

En la época de su muerte se dedicaba a

Será recordado por para llegar a ser

Será llorado por porque porque

El mundo perderá su valiosa contribución en las áreas de Aunque siempre lo deseó, no logró El cuerpo será Se pueden enviar flores En lugar de flores

Al terminar, de redactar tu esquela, que te gustaría que apareciera si murieras dentro de 5 años. Este es un ejercicio fuerte, ayuda a ver la propia vida más claramente desde la perspectiva de tu muerte imaginada, con el fin de motivar valores y reforzar el hecho de que todavía te cuenta con toda una vida por delante y que puedes hacer con ella lo que se quiera, es una actividad para reflexionar sobre lo que has hecho hasta este momento y lo que puedes hacer para mejorar tu futuro.

Reflexión: Como ves tus pensamientos negativos te afectan irremediablemente, sin embargo si tú los cambias, empiezan a cambiar al poder hacer el análisis y esto va en mejora de tu actitud, por lo tanto tus acciones y tu futuro y lo mejor tú presente.

Como te estás dando cuenta esto ayuda a clarificar tus valores y reforzar el hecho de que todavía cuentas con toda una vida por delante y que puedes hacer con ella lo que quieras, saber lo que has hecho hasta este momento y lo que puedes hacer y mejorar a futuro.

\section{Actividad 18. Cambiando el Guión de la Película.}

Ahora, nuevamente tendrás que grabar la siguiente actividad, dando tiempo para realizar las acciones planteadas cuando encuentras los puntos suspensivos. Te recomiendo que te sientes cómodamente sin cruzar manos ni piernas, pon la grabación. 


\section{Instrucciones:}

Cierra por un momento los ojos y, mientras, presta atención a tu respiración.

Lentamente cuenta hasta cuatro, al contar toma todo el aire que puedas... Retén el aire mientras cuentas hasta cuatro... Exhala el aire mientras cuentas hasta cuatro... Quédate sin aire y cuenta hasta cuatro... Cuenta hasta cuatro tomando todo el aire que puedas... Retén el aire mientras cuentas hasta diez...Exhala el aire mientras cuentas hasta cuatro... Quédate sin aire y cuenta hasta cuatro... Cuenta hasta cuatro tomando todo el aire que puedas... Retén el aire mientras cuentas hasta cuatro.... Exhala el aire mientras cuentas hasta cuatro... Quédate sin aire y cuenta hasta cuatro... respira normalmente.

Recuerda un momento en qué te hubiera gustado haber actuado de diferente manera... Recuerda lo que viste..., escuchaste... y sentiste... Pregúntate: ¿Qué podría haber hecho que fuera diferente?...Imagina una escena en tu mente de lo que hubiera pasado si lo hubieras hecho en forma diferente... Ahora visualiza tu imagen en la escena...Pregúntate: ¿Qué estoy pensando?... ¿Esta alternativa me hace sentir bien?... Puedes crear en tu cerebro más alternativas y seguir el mismo procedimiento... Escoge la alternativa más adecuada y tu cerebro encontrará las acciones que la hagan realidad...

Ahora genera las imágenes que te representen viviendo esa situación de manera vívida. Obsérvalas..., ahora escucha lo que ocurre y de manera especial lo que te dices a ti mismo..., y siente el gozo de las emociones y las actividades que estás haciendo siéntelas con todo detalle... guarda en un lugar especial de tu cerebro está mejor alternativa y siéntela totalmente tuya, es muy real...

Realiza una respiración suave profunda y lenta, y al exhalar mueve suavemente tu cuerpo... tus manos y pies..., tus brazos y piernas... tu cuerpo, cuello y cabeza... Ahora, ubícate nuevamente en el aquí y el ahora, abre lentamente tus ojos.

Reflexiona: Te diste cuenta que hay muchas maneras de responder ante un evento y que van a depender de tus habilidades y tus experiencias. Y lo más importante es que con este trabajo estás teniendo herramientas para desatorarte y salir adelante. 
Mejora tu calidad de vida y rendimiento académico a través del autoaprendizaje

Espero que hayas logrado desarrollar todas tus actividades para ir alcanzando el objetivo, Recuerda que este es un proceso prolongado y se deberás continuar trabajando con él por bastante tiempo, porque de otra manera te ganará la rutina, que es la costumbre que tenías antes, pero no te gustaba, por eso elegiste cambiar, ojalá que sigas adelante hasta hacerlo tu estilo de vida y la herencia para tus familiares y amigos, así como a tus hijos a quienes seguramente les harás el gran favor de evitarles problemas. Puedes volver a trabajar con algunos ejercicios y desarrollarlos nuevamente para fortalecer los cambios en tus pensamientos, a fin de que tus sentimientos y conductas sean apropiadas y que actúen de forma integral.

¡Gracias por todo tu trabajo y compromiso sigue adelante siendo mejor persona! 


\section{Bibliografía}

ACEVEDo, I. A. (1997) Aprender Jugando. Dinámicas Vivenciales para capacitación, docencia y consultoría. Tomos 1, 2 y 3. Editorial Limusa: México.

Alfaro, S. (2012) Habilidades Comunicativas, descargado en: http://ejercicio habilidadescomunicativas.blogspot.mx/2012/04/concepto-de-las-habilidades.html

AUtOCONCIENCIA. de http://psicologiabienestar.wordpress.com/2011/04/11/autocon ciencia/ recuperada 25/03/2014.

Armenta, Hurtarte. C. \& Díaz-Loving, R. (2006) Comunicación y satisfacción: Analizando la interacción de pareja. La Psicología Social en México, México: AMEPSO, XII, 173178.

Beauregard, L.; Bouffard, R. \& Duclos, G. (2005) Autoestima para quererse más y relacionarse mejor. Madrid: Narcea ediciones.

BECK, A.T. y STEER, R.A. (1988) Inventario de ansiedad de Beck. Recuperado en: http:// www.bimbela.com/BAl-es2.pdf.

BISHOP, S. (2000) Desarrolle su asertividad. Barcelona: Gedisa.

BRANDEN, N. (1997) Los seis pilares de la autoestima. Editorial Paidós. Edición 3a. México

BRANDEN, N. (2000) Los 6 pilares de la autoestima Paidós México.

Branden, N. (1997) El Respeto hacia uno mismo. Editorial Paidós, México.

Branden, N. (2003) Los seis pilares de la autoestima. México: Paidós.

Bravo, N. (1995). En Valores Humanos. En: Araya Pereira, T.; García Pino, R. y Jara FerRAdA, E. (2006) Educar en Valores, Vivir en Virtudes. Una instancia de vivencias desde la educación física. Pensamiento Educativo. Vol. 38, julio, pp. 125 - 140.

Bravo H, A \& Garzón Perilla, G. A. (2010) Habilidades para la vida. En búsqueda del desarrollo del ser humano integral. En Ippolito-Shepherd J., Promoción de la salud. Experiencias internacionales en escuelas y universidades (pp. 123-139). Buenos Aires: Paidós.

BURNS, D. (2010) Sentirse bien: una nueva terapia contra las depresiones. México: Paidós

Castro Sariñana, M.E. y Llanes J. Modelo Preventivo de Riesgos Psicosociales CHIMALLI 45. Instituto de Educación Preventiva y Atención de Riesgos, A.C. En-. Modelos 
Preventivos, serie planeación, del Consejo Nacional contra las Adicciones. http:// www.conadic.salud.gob.mx/pdfs/publicaciones/modprev.pdf.

Ceberio, M. (2006) La buena comunicación: Las posibilidades de la interacciónhumana. México: Paidós.

CondE, S. (2010) Educar y Proteger: El Trabajo Docente en una Escuela Segura. Guía para Docentes. Del Programa de Escuela Segura de la SEP.

CORTESE, A. La Oratoria www.competir.com/es/profesionales/capacitacion/articulos.asp. Coon, D. (1995) Psicología exploraciones y aplicaciones. $8^{a}$ edición. Estados Unidos. Editorial Thompson.

Del Prette, Z. A. \& Del Prette, A. (1999) Psicologia das Habilidades Sociais: Terapia e Educaçao. Petrólis: Voces (4ạ ediçao 2006).

DerlengA, V. J. (1984) Self-disclosure and Intimate Relationships. En Derlenga, V. J. (Ed.) Communication, Intimacy, and Close Relationships. USA: Academic Press.

DíAz, G. Técnicas De Expresión. Manual Oral. http:// Barrioperu.Terra.Com.Pe/Gregorj/ Tcnicas.Htm.

DUgGer, J. (2006) Escucha Eficaz: La clave de la comunicación. España: FC Editorial.

ElLIS A., \& ABRAHMS E. (1978). Terapia Racional Emotiva (TRE): Mejor salud y superación personal afrontando nuestra realidad. Nueva York: Springer Publishing Company.

ELLIS, A. (1995) Better, deeper, and more enduring brief therapy: The rational emotive behavior therapy approach. New York: Brunner/Mazel.

ELLIS A, BLAU S. (compilador) (2000) Vivir en una sociedad irracional; una huía para el bienestar mediante la terapia racional emotiva-conductual. Madrid: Paidós.

EluIS A. (2003) Una nueva guía para una vida racional. España: Obelisco.

ELLIS A. (2003) Ser feliz y vencer las preocupaciones. España: Obelisco.

EluIs A. (2014) Usted Puede Ser Feliz: Terapia Racional Emotiva Conductual para superar la ansiedad y la depresión. España: Paidós.

ESCALA QUINCEY DE EMPATíA. http://guiadeejercicios.blogspot.mx/2005/04/ejercicio-10escala-de-quincey-de.html descargado noviembre 2013.

Feldenkrais, M. 1999. Autoconciencia del Movimiento. Editorial Paidós. México Filıozat, I. (1998) El Corazón Tiene sus Razones. México, Urano.

FITZPATRICK, M. A. (1988) Between husbands and wives, communication in relationships. En B. Rubin (Ed.) Communication yearbook. New Bunswick, New Jersey: Transaction Books. 
Fournier, M. C. Comunicación Verbal. Itesm. Campus Ciudad de México.

GARDNER, H. (1994) Educación artística y desarrollo humano. Barcelona: Paidós.

GeRZA Grupo Dinámicas gratuitas del http://www.gerza.com/dinamicas/dinamicas.html Giménez. Cortes. Et Al. (2003) Confiabilidad y valoración en niños mexicanos de un instrumento que mide la autoestima. Salud mental. Vol. 26. Núm. 004.pp 40-46.

Goleman, D. (2000) Inteligencia Emocional. México, Vergara.

GoNZÁLEZ, F. (1985) La personalidad, su educación y desarrollo. Editorial Ciencias Sociales. La Habana.

Gottman, J. Y NAN, S. (2004) Siete Reglas de Oro para Vivir en Pareja. Un estudio exhaustivo sobre las relaciones y la convivencia. ISBN 968-5956-53-7 México, DE BOLSILLO.

HeRRÁn, A. DE LA (Coord.) (2003) Guías Didácticas para la Formación de Maestros. Huelva: Hergué.

Heman Contreras, Arturo (2010) Manual de Terapia Cognitivo Conductual. ISBN: 978607-00-3051-2 editorial: Heman Contreras, Arturo. México.

HidAlgo, C. \& ABARCA, N. (1999) Comunicación interpersonal: Programa de entrenamiento en habilidades sociales. México: Alfaomega grupo editores.

IBARRA, L. M. (2007) Aprende Mejor Con Gimnasia Cerebral, Garnick ed. México.

JURGEVIC, D. (2000) Autoestima seguro de uno mismo. Equipo editorial: Madrid.

Kotliarenco, Ma A.; CÁceres, I. \& Fontecilla, M. (1997) Estado de Arte en Resiliencia. Organización Panamericana de la Salud (OPS) Oficina Sanitaria Panamericana, Oficina Regional de la Organización Mundial de la Salud (OMS).

Lega L, CABallo E.V. \& Ellis, A. (1997) Teoría práctica de la terapia racional emotivoconductual. Madrid: Siglo XXI.

LEGA, L. (2007) La historia de Albert Ellis: Celebrando 50 Años de TREC. New York: Albert Ellis Institute.

LEón, A. (2002) Estrategias para el desarrollo de la comunicación profesional. México: Editorial Limusa.

LEVY GERSHEN (1993). Desarrolla tu poder personal y autoestima defendiéndote. Editorial PAX. México.

Lopez de Bernal, M.E., González MedinA, M.F. (2004). Inteligencia Emocional. México: Editorial Dimas, 82 - 120. 
Mejora tu calidad de vida y rendimiento académico a través del autoaprendizaje

Maldonado, W. H. (1966) Manual De Comunicación Oral. Ed. Alhambra. México.

Mc Entee Sullivan, E. (1966) Comunicación Oral. Ed. Mc Graw-Hill. México.

Mangrulkar, L.; Whitman, V. \& Posner, M. (2001) "Enfoque de habilidades para la vida para un desarrollo saludable de niños y adolescentes". Organización Panamericana de la Salud (OPS). División de Promoción y Protección de la Salud (Septiembre) pp. 13-33.

Marroquín, M. \& VilLA, A. (1998) La comunicación interpersonal. España: Ediciones Mensajero.

Maslow, A. (1943) La Teoría de las Necesidades Humanas. En Sanchéz Valdeverde, S, (s/f) La Teoría de Maslow sobre las Necesidades Humanas. http://apsd.wikispaces.com/ file/view/UT1.+ Necesidades_Teoria+de+Maslow.pdf.

Molinaro, A. R. (s/f) Como optimizar la comunicación en:http://www.enplenitud. com/ como-optimizar-la-comunicacion.html\#ixzz3tDo3GqFVMonbourquetTe (2002) de la autoestima a la estima de lo profundo de la psicología espiritual. España. Sal terrae.

Montoya, M. (2001) Autoestima. México: Pax.

NiRenberG, O. (2006) El diagnóstico participativo local en intervenciones sociales. Centro de Apoyo al Desarrollo Local (C E A D E L), Cuaderno № 44, en: http://www.ceadel. org.ar/cuadernos/Equipo Salud_LeySSR-40.pdf.

Norwood, R. (2002) Las Mujeres que Aman Demasiado. México, Punto de Lectura.

Nuñez Montenegro, E. (s/f) 5 Pasos para mejorar tu habilidad de hablar en público. Por http://www.fundapymes.com/blog/5-pasos-para-mejorar-tu-habilidad-de-hablaren-publico/

OTONE, P. (1999) El Autoconcepto formación medida e implicaciones de la personalidad. Editorial Narcea: Madrid.

OMS, (2001)

PASCUAL, R. D. (2006) Fundamentos de la comunicación humana. Club Universitario.

PSICOLOGíA ON-LINE. http://www.psicologia-online.com/ recuperado en 2013.

RATHUS, (1973) Test de asertividad. Recuperado en: http://es.scribd.com/doc/53717282/ Test-Asertividad-de-Rathus-Manual.

Remolina VARgas G. (2005) La Formación en Valores S.J. Rector de la Pontificia Universidad Javeriana - Bogotá en: http://www3.ucn.cl/ofec/VALORES.pdf descargado en 2013. 
Rogers, C. (1966) Psicoterapia Centrada en el Cliente. Buenos Aires: Paidós.

Rosemberg (1964) Escala de Autoestima. Recuperada en: http://www.sasia.org.ar/sites / www.sasia.org.ar/files/ESCALA_AUTOESTIMA_ROSEMBERG.pdf.

ToMkıNs. S. S. (1963) A Basic Dimension of Ideology and Personality The right and the left. In R. W. White (Ed.). The study of lives. New York: Atherton.

RABINDRANATH TAgore (1882) "Canciones del atardecer" En: http://amediavoz.com/ tagore.htm.

RESPETO (s/f) http://www.educacion.navarra.es/documents/27590/205384/ACTIVIDAD++ Respeto++Una+peque\%C3\%B1a+historia+cuestionario.pdf/ca5cf376-be7d-42c9b528-d2946c027156.

RoJAS, E. 2001. Quien eres de la personalidad a la autoestima. Planeta. México.

Romagnoli, C.; MenA, I. \& Valdés, A. (2007) ¿Qué son las Habilidades Socioafectivas y Éticas? Recopilado de: http://valoras.uc.cl/wp-content/uploads/2010/09/ habilidades_socioafectivas.pdf.

SAAVEDRA, M. La admiración: la clave de los amores que duran. En: http://cosianima.com/ spip.php?article1462 descargado junio de 2013.

SALAS, C. Oratoria Www.Multired.Com/Profesio/Oratoria.

SÁNCHEz ARAgón, R. (1995) El amor y la cercania en la satisfacción de pareja a través del ciclo de vida. (Tesis de maestria no publicada) Universidad Nacional Autonoma de México, México.

Sánchez Aragón, R. \& Díaz-Loving, R. (2003) Patrones y estilos de comunicación de la pareja: Diseño de un inventario. Anales de Psicología. 19, 202, 257 - 227.

SATIR, V. (1986) Relaciones Humanas en el Núcleo Familiar. México: Editorial Pax México, 122-139.

SATIR, V. (1991) Ejercicios Para La Comunicación. Editorial Pax México.

SolsonA, F. (1998) Como Mejorar La Presentaciones Audiovisuales. Manual.

SSP (s/f) Guía del Taller Prevención de la Violencia en el Noviazgo. En: www.ssp. gob.mx/ portalWebApp/ShowBinary?nodeld=/.../1214154//...Secretaria de Salud Pública. Consultado el 20-08-13.

TWERSKI, A. (1999) Sé positivo. Editorial Paidós. México.

VAN-DER HofSTAdT, C. (2005) El libro de las habilidades de comunicación: Cómo mejorar la comunicación personal. México: Díaz de Santos. 
Mejora tu calidad de vida y rendimiento académico a través del autoaprendizaje

WATZlaWiCK, P., BAVELAS, J. \& JACKSON, D. $(1967,2002)$ Teoría de la comunicación humana. Barcelona: Herder Editorial.

Zires, M. (1992) De La Voz, La Letra Y Los Signos Audiovisuales En La Tradición Oral Contemporánea En América Latina: Algunas Consideraciones Sobre La Dimensión Significante DE LA COMUNICACIÓN ORAL. Universidad Autónoma Metropolitana. 


\section{Índice de autores}

\begin{tabular}{|l|c|}
\hline & Páginas \\
\hline Alfaro, S. (2012) & 174 \\
\hline Armenta Hurtarte \& Díaz-Loving (2006) & 166 \\
\hline Beauregard, L.; Bouffard, R. \& Duclos, G. (2005) & 102 \\
\hline Beck, A.T. y Steer, R.A. (1996) & 73 \\
\hline Bishop, S. (2000) & 99,100 \\
\hline Branden, N. (2003) & 101 \\
\hline Bravo, N. (1995) & 149 \\
\hline Bravo, N. (2001) & 151 \\
\hline Bravo, N. Y Garzón, (2010) & 2 \\
\hline Castro Sariñana, M.E. y Llanes J. (2007) & 103 \\
\hline Ceberio, M. (2006) & 91 \\
\hline Conde, S. (2010) & 103,106 \\
\hline Derlenga, V. J. (1984) & 165 \\
\hline Del Prette, Z. A. \& Del Prette, A. (1999) & 84 \\
\hline Díaz-Loving, R. y Sánchez Aragón, S. (2002) & 164,165 \\
\hline Dugger, J. (2006) & 95,96 \\
\hline Ellis, A. (1962) & 203 \\
\hline Ellis A., \& Abrahms, E. (1978) & 204 \\
\hline Ellis, A. (1995) & 213 \\
\hline Fitzpatrick, M. A. (1988) & 165 \\
\hline Fritzen, (1989) & 116 \\
\hline Gerza (s/f) & 141 \\
\hline González (1985) & 106 \\
\hline Gottman, J. y Nan, S. (2004) & 192 \\
\hline Gottman, J. y Silver (2006) & 195 \\
\hline Heman, A. (2010) & 211 \\
\hline Herrán, A. de la (2003) & 106 \\
\hline
\end{tabular}


Mejora tu calidad de vida y rendimiento académico a través del autoaprendizaje

\begin{tabular}{|l|c|}
\hline & Páginas \\
\hline Hidalgo, C. \& Abarca, N. (1999) & $83,97,98,102$ \\
\hline Kotliarenco, Ma A.; Cáceres, I. \& Fontecilla, M. (1997) & 78 \\
\hline León, A. (2002) & 192 \\
\hline Jankowiak y Fisher (1992) & 27,131 \\
\hline Maslow, R. (1943) & 106 \\
\hline Molinaro, A. R. (s/f) & 100 \\
\hline Montoya, M. (2001) & 145 \\
\hline Nuñez Montenegro, E. (s/f) & vii \\
\hline OPS/OMS, (2001) & 1 \\
\hline OMS (2003) & 78 \\
\hline Pascual (2007) & 106 \\
\hline Psicologia - online & 73 \\
\hline Rathus (1973) & 150 \\
\hline Remolinam Vargas, G. (2005) & 106 \\
\hline Rogers, C. (1966) & 73 \\
\hline Rosemberg (1964) & 198 \\
\hline Saavedra, M. (s/f) & 165 \\
\hline Sánchez Aragón, R. (1995) & 65 \\
\hline Satir, V. (1986) & 71 \\
\hline Satir, V. (1991) & 135 \\
\hline SSP (s/f ) & 95 \\
\hline Tomkins. S. S. (1963) & $94,90,92$ \\
\hline Van-Der Hofstadt, C. (2005) & 97 \\
\hline Watzlawick, P., Bavelas, J. \& Jackson, D. (1967, 2002) & \\
\hline Wolpe, J. (1958) & 73 \\
\hline
\end{tabular}




\section{Acerca de los autores coordinadores}

Nombre de la responsable: JULIETA MARÍA DE LOURDES GARCÍA PÉREZ.

Teléfono de oficina: 56230596; Correo electrónico: july.gap@gmail.com, Nivel máximo de estudios: Maestría; Nivel de PRIDE: C; Área: Área de las Ciencias Sociales; Disciplina: Psicología; Categoría y nivel: PROFRA. ASOC. "C" de T C definitiva; y, Entidad académica de adscripción: UNAM, FES Zaragoza.

Formación profesional: Estudiante del Doctorado Ciencias de la Educación por el Colegio de Estudios de Posgrado de la Ciudad de México; Licenciatura en Psicología, por la UNAM; Maestría en Salud en el Trabajo por la UAM, obteniendo la medalla al mérito académico; Especialidad en Terapia Racional Emotiva por el ITREM (afiliado al ITRENY); Diplomados en: 1) Educación Sexual por Asociación Mexicana de Educación Sexual (AMES), 2) Estadística Aplicada por la UAM, 3) en Formación Pedagógica por la FESZ, 4) La Práctica Docente en los Sistemas Abiertos y a Distancia. ENEO, ETS y FES Zaragoza UNAM; 5) Diplomado de la Tutoría en la Educación Superior y 6) Diplomado de Aplicaciones de las TIC para la Enseñanza.

Categoría: Profesora Asociada C. de T. C. def., del Área de Metodología General y Experimental, Carrera de Psicología, FES Zaragoza, UNAM. Con 35 años de antigüedad. Participación en diversos Órganos Colegiados. Publicaciones sobre metodología, procesos psicológicos, factores psicosociales y Presentaciones en foros de Psicología tanto nacionales como internacionales.

Soy responsable del proyecto PAPIME PE303213 Mejora del Rendimiento Académico a través del Fortalecimiento de las Habilidades Psicosociales; participé en la elaboración del proyecto de reestructuración de los Laboratorios de Psicología Experimental así como en el PROYECTO PAPIME EN312203 “Desarrollo Integral de los Laboratorios de Psicología” de 2003 a 2006; “Programa de Apoyo a la Enseñanza de las Matemáticas y la Estadística en Psicología" (PAPIME PE305407); PROYECTO PAPIME PE305907 (2007-2009) “Vinculación de las Competencias Laborales y la Formación de los Egresados de Psicología FES Zaragoza"; y el proyecto PAPIME 
Mejora tu calidad de vida y rendimiento académico a través del autoaprendizaje

PE302111 “Un Programa de Intervención, basado en la Neuropsicología Pedagógica para Estudiantes en Matemáticas-Estadística e la Carrera de Psicología".

He participado como ponente en congresos y eventos académicos, con temas sobre Desarrollo de Habilidades Psicosociales y Educación.

He dirigido tesis y participado como sinodal en varios exámenes profesionales. He coordinado un programa de servicio social sobre el Fortalecimiento de Habilidades Psicosociales para Estudiantes Universitarios y especialmente enfocado en Psicólogos, con varios pasantes, a quienes les he brindado capacitación, asesoría y supervisión.

He impartido tutorías desde 2001 con becarios de PRONABES, en 2002 con las tutorías del PFEL e institucionales (PIT) tomando la capacitación para ser tutor, en la 1a generación y me encuentro desarrollándolas hasta la actualidad.

He impartido talleres sobre desarrollo de habilidades psicosociales en diversas instituciones como UNAM FES Zaragoza, el Instituto Tecnológico de Estudios Superiores de Monterrey campus Cd. de México (ITSEM) y el Colegio Nacional de Educación Profesional Técnica (CONALEP), dirigidos a estudiantes, profesores y padres de familia, desde hace 12 años.

He dirigido varias tesis y reportes de servicio social; he participado como sinodal de una amplia cantidad de trabajos de titulación, tanto tesis, tesinas, reportes de servicio y trabajos de diplomados.

Nombre de la académica: JUANA ALEJANDRA VILLAGOMEZ RUIZ.

Correo electrónico: alejandravillagomezruis@gmail.com

Nivel máximo de estudios: Licenciatura; Nombramiento académico: PROFRA. ASIG. B def. Entidad académica de adscripción: UNAM FES Zaragoza.

Licenciatura en Psicología, por la UNAM; Maestría Pasante de la Maestría en Ciencias de la Salud Pública en la FES Zaragoza. UNAM en convenio con la Universidad Autónoma de Tlaxcala 
Diplomados en: 1) Formación de Profesores en coordinación con CONACyT 2) Prospectiva Universitaria de la Ciencia y la Tecnología ,3) Formación Pedagógica por la FESZ, 4) La Práctica Docente en los Sistemas Abiertos y a Distancia. ENEO, ETS y FES Zaragoza UNAM; 5) Diplomado de Aplicaciones de las TIC para la Enseñanza. Certificación en Psicología Positiva por el TEC Milenio.

Categoría: Profesora Asignatura B definitivo., del Área de Formación Básica, Carrera de Psicología, FES Zaragoza, UNAM. Con 38 años de antigüedad. Participación en diversos Órganos Colegiados. Presentaciones en congresos y foros de Psicología. He participado junto con otros profesores en la elaboración del Programa de Estudios Teórico-Metodológico como parte del Proyecto de Modificación del plan de Estudios de la Carrera de Psicología PROYECTO PAPIME Programa Integral de Aproximación Docente a la Enseñanza. Clave EN312303; y, en el proyecto PAPIME PE303213 Mejora del Rendimiento Académico a través del Fortalecimiento de las Habilidades Psicosociales.

He impartido talleres sobre desarrollo de habilidades psicosociales en diversas instituciones como UNAM FES Zaragoza, el Instituto Tecnológico de Estudios Superiores de Monterrey campus Cd. de México (ITSEM) y el Colegio Nacional de Educación Profesional Técnica (CONALEP), en la Armada de México dirigidos a estudiantes, profesores y padres de familia; He dirigido varias tesis y reportes de servicio social; he participado como sinodal de una amplia cantidad de trabajos de titulación, tanto tesis, tesinas, reportes de servicio. He coordinado y dirigido un servicio social con varios pasantes, a quienes les he brindado capacitación, asesoría y supervisión.

He participado como ponente en congresos, con temas sobre Desarrollo de Habilidades Psicosociales.

He impartido tutorías desde 2001 con becarios de PRONABES, en 2002 con las tutorías del PFEL e institucionales (PIT) tomando la capacitación para ser tutor, en la 1a generación y me encuentro desarrollándolas hasta la actualidad. 
Nombre del académico: GERARDO REYES HERNÁNDEZ.

Correo electrónico: gerardoreyeshernandez@yahoo.com.mx; Nivel máximo de estudios: Licenciatura; Nombramiento académico: Profesor Asociado C. de T. C. Interino; Entidad académica de adscripción: FES Zaragoza.

Licenciatura en Psicología, por la UNAM. Maestría: Pasante de la Maestría en Ciencias de la Salud Pública en la FES Zaragoza, UNAM en convenio con la Universidad Autónoma de Tlaxcala; y pasante en Maestría en Ciencias con especialidad en Administración y desarrollo de la Educación, del IPN. He tomado diversos cursos y talleres sobre didáctica, metodología y actualización profesional.

Categoría: Profesor Asociado "C". de T. C. Interino., del Área de Formación Básica, Carrera de Psicología, FES Zaragoza, UNAM. Con 27 años de antigüedad. Participación en diversos Órganos Colegiados. He participado junto con otros profesores en la elaboración del Programa de Estudios Teórico-Metodológico como parte del Proyecto de Modificación del plan de Estudios de la Carrera de Psicología.

He impartido talleres sobre desarrollo de habilidades psicosociales en diversas instituciones como UNAM FES Zaragoza, dirigido a estudiantes, profesores y padres de familia en el Instituto Tecnológico de Estudios Superiores de Monterrey campus Cd. de México (ITSEM) y el Colegio Nacional de Educación Profesional Técnica (CONALEP). Así como en diferentes hospitales a personal de la Salud.

Participante del proyecto PAPIME de Investigación "Mejora del Rendimiento Académico a través del Fortalecimiento de las Habilidades Psicosociales".

He dirigido varias tesis y reportes de servicio social; he participado como sinodal de una amplia cantidad de trabajos de titulación, tanto tesis, tesinas, reportes de servicio. He coordinado y dirigido un servicio social con varios pasantes, a quienes les he brindado capacitación, asesoría y supervisión. 
He participado como ponente en congresos, con temas sobre Desarrollo de Habilidades Psicosociales.

He impartido tutorías a los estudiantes que me lo solicitan, para trabajar diferentes aspectos, tanto emocionales, familiares como académicos.

Gracias por tu preferencia, si requieres comunicarte con nosotros:

FES Zaragoza, UNAM. Edif A4- PA23 tel. 56230596

Gracias por tu atención y para tu apoyo cuentas con el siguiente correo con el que te puedes comunicar con nosotros:

serviciosocialhabilidadesps@gmail.com 


\section{MEJORA TU CALIDAD DE VIDAY RENDIMIENTO ACADÉMICO A TRAVÉS DEL AUTOAPRENDIZAJE}

Este libro permite fortalecer a los estudiantes las habilidades cognitivas, emocionales y de interrelación para trabajar de manera óptima en sus estudios y en su vida cotidiana, ayudándoles de una manera sencilla y progresiva, planeada de manera vivencial y reflexiva.

Así mismo, contribuye al desarrollo de habilidades y destrezas para la vida cotidiana y profesional de todas aquellas personas que deseen una mejor calidad de vida. Esta modalidad de guía permite aprender al propio ritmo así como fortalecer algunos temas particulares. Siendo una excelente alternativa para aquellas personas que no puedan tomar el taller-vivencial de manera presencial

Este libro es el resultado de la experiencia en la impartición de talleres a lo largo de 17 años en los cuales hemos sido testigos de un cambio sustancial en los estudiantes, profesores, padres y trabajadores.

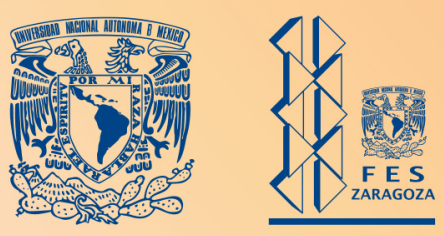

Facultad de Estudios Superiores Zaragoza, Campus I. Av. Guelatao No. 66 Col. Ejército de Oriente, Campus II. Batalla 5 de Mayo s/n Esq. Fuerte de Loreto. Col. Ejército de Oriente. Iztapalapa, C.P. 09230 México D.F.

http://www.zaragoza.unam.mx

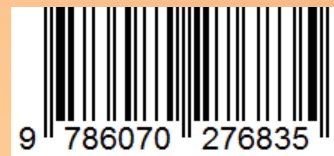

